UNIVERSIDADE DE SÃO PAULO FACULDADE DE ARQUITETURA E URBANISMO

IVANIR REIS NEVES ABREU

\title{
CONVÊNIO ESCOLAR: UTOPIA CONSTRUÍDA
}

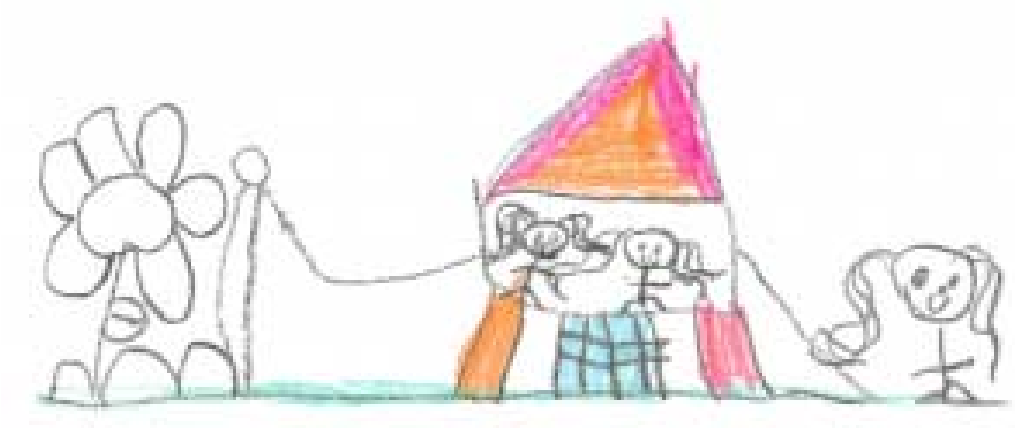

SÃO PAULO 
IVANIR REIS NEVES ABREU

\section{CONVÊNIO ESCOLAR: UTOPIA CONSTRUÍDA}

Dissertação de mestrado apresentada à Faculdade de Arquitetura e Urbanismo da Universidade de São Paulo para obtenção do título de

Mestre em Arquitetura e Urbanismo

Área de concentração: Projeto de Arquitetura Orientador: Prof. Dr. Adilson Costa Macedo

São Paulo 2007 
AUTORIZO A REPRODUÇÃO E DIVULGAÇÃO TOTAL OU PARCIAL DESTE TRABALHO, POR QUALQUER MEIO CONVENCIONAL OU ELETRÔNICO, PARA FINS DE ESTUDO E PESQUISA, DESDE QUE CITADA A FONTE,

\section{Abreu, Ivanir Reis Neves}

A162c Convênio escolar: utopia construída / Ivanir Reis Neves Abreu. - São Paulo, 2007.

$$
334 \text { p. : il. }
$$

Dissertação (Mestrado - Área de Concentração: Projeto de Arquitetura) - FAUUSP.

Orientador: Adilson Costa Macedo

I.Escolas (Arquitetura) - São Paulo(SP) 2.História da arquitetura I.Título

CDU 727.I(8I6.II) 
Aos que me educaram: Francisco e Teresinha

A quem comigo educa: Nice Aos que educo: João Pedro e Mariana 



\section{AGRADECIMENTOS}

Agradeço a compreensão de todos aqueles que sentiram minha falta, quando precisei priorizar esta pesquisa; agradeço aos professores Paulo Bruna, Hugo Segawa, Mônica Junqueira, José Eduardo de Assis Lefévre, Dario Montesano e Benedito Lima de Toledo que ministraram as disciplinas que cursei na pós-graduação e pelas possibilidades que me ofereceram em seus cursos de ampliar o horizonte desta pesquisa; aos arquitetos da FDE, com quem divido minhas cotidianas descobertas e angústias relativas à arquitetura escolar; à amiga Naide Patapas, ao abrir meu caminho para esta especialidade da arquitetura, quando tudo parecia muito confuso; aos professores Alexandre Delijaicov e novamente a Mônica Junqueira, pela pertinência dos comentários na qualificação desta dissertação, fundamentais para a finalização desta pesquisa; ao meu orientador Adilson Costa Macedo, que sempre confiou em minha dedicação e que me deixou imprimir um ritmo próprio ao trabalho, o que permitiu que eu pudesse me dedicar aos meus filhos pequenos que cresceram junto com este mestrado. Agradeço, finalmente, à estratégica colaboração de Samira Chahin que, pacientemente, organizou todos os desenhos das escolas aqui apresentadas, à colaboração de Luciana Rodrigues, que possibilitou com seu projeto gráfico, a qualidade desta apresentação final, e a Vera Lígia Amadi, por conhecer, mais do que todos, as entrelinhas deste texto em suas minuciosas revisões. 



\section{RESUMO}

Esta dissertação tem como objeto de estudo a análise de um conjunto de escolas construído entre os anos de 1949 e 1953, quando vigorou o $2^{\circ}$ Convênio Escolar, acordo entre Estado e Município, com a finalidade de zerar, até as comemorações do IV Centenário, o grave defict de salas de aula na cidade de São Paulo. A equipe de profissionais, contratados para a concepção e desenvolvimento dos projetos, dirigida pelo arquiteto Hélio de Queiroz Duarte, era composta pelos arquitetos Eduardo Corona e Roberto Goulart Tibau, cariocas formados pela Escola Nacional de Belas Artes e pelos paulistas Oswaldo Côrrea Gonçalves, engenheiroarquiteto, e Ernest Robert Carvalho Mange, engenheiro, ambos formados pela Escola Politécnica da Universidade de São Paulo. $\bigcirc$ trabalho dessa equipe resultou na construção de 52 edifícios escolares aos quais foram aplicados, em seus programas arquitetônicos, os conceitos de uma escola aberta à comunidade, conforme apregoava o educador Anísio Teixeira, com quem o arquiteto Hélio Duarte trabalhou, na Bahia, no planejamento de uma rede de escolas públicas voltada à inclusão das crianças carentes, que não tinham acesso à educação pública. Esse convívio entre o educador e o arquiteto traduziu-se em sólidos conceitos pedagógicos, aplicados na concepção dos projetos arquitetônicos do convênio escolar: arquitetura e pedagogia, a partir dos princípios utópicos da arquitetura moderna e das idéias libertadoras da "escola nova" 
resultaram na unidade que caracterizou esse conjunto de escolas. $\bigcirc$ meu objetivo em pesquisar esse conjunto de obras está na possibilidade de reconstruir a história da moderna arquitetura brasileira através do viés da educação e, para tanto, traçar uma linha histórica, objetivando localizar o início da ligação entre os pedagogos escolanovistas e a arquitetura. No início dos anos 30, em plena era Vargas, assistimos à construção de um plano visando ao desenvolvimento do país, a partir do estabelecimento de um parque industrial nacional. Esse movimento provocou profundas mudanças na estrutura social brasileira. A educação, através do movimento escolanovista, passou a ser indutora dessa transformação, ao lutar pelo direito de todas as crianças de freqüentarem uma escola pública, além de apresentar um novo modelo pedagógico decorrente dessa nova postura que levou à necessidade de um novo espaço físico para abrigar essa escola renovada. $\bigcirc$ plano de desenvolvimento nacional, no plano cultural, uniu políticos e intelectuais na construção de uma identidade nacional, e a arquitetura, enquanto expressão de um tempo, apropriou-se dos conceitos racionalistas da arquitetura moderna internacional que, nas mãos de jovens arquitetos, pôde encontrar na arquitetura escolar um rico campo de experimentação. O cenário desse movimento é a cidade de São Paulo que, em meados da década de 40, já havia se transformado em metrópole internacional e revelava, em seu espaço urbano, a contradição entre a riqueza e a pobreza, na divisão entre centro e periferia. As escolas do convênio escolar vieram atender aos bairros que tiveram, na escola pública, o primeiro sinal da presença de um Estado que, saído da ditadura de Getúlio Vargas, democratizava-se. 


\section{ABSTRACT}

This thesis focuses on the analysis of a set of schools built between 1949 and 1953 in São Paulo, during the 2nd School Agreement ( $2^{\circ}$ Convênio Escolar), a contract between state and municipality authorities, which its main purpose was to extirpate the serious lack of classrooms,until the Celebration of the 400th Anniversary of the city of São Paulo.

The team engaged in the conception and development of the projects was coordinated by the architect Hélio de Queiroz Duarte and composed by two architects from Rio de Janeiro, Eduardo Corona and Roberto Goulart Tibau, both graduated at Escola Nacional de Belas Artes, Oswaldo Correa Gonçalves, engineer-architect and Ernest Robert Carvalho Mange, engineer, both graduated at Escola Politécnica from University of São Paulo.

The result of their work are 52 schools which have been built with a specific architectural programme, concepts of a school opened to the community, according to Anísio Teixeira's beliefs, educator, with whom Hélio Duarte has worked in Bahia, developing a public school planning to include deprived children and give them opportunity to attend a school.

This exchange of ideas between architect and educator resulted in solid pedagogic concepts, and were applied on the projects of the Convênio Escolar 
,architecture and pedagogy, beginning with the idealistic principles from modern architecture and the renewal ideas from New School Movement in Brazil (Escola Nova), coming from the international movement "Education Act", resulted in an identity which characterized this set of schools.

The objective of this research is to create the possibility to recognize the history of Brazilian Modern Architecture from the educational perspective and design a time scale to locate the beginning between pedagogues from Escola Nova movement and architecture.

In the beginning of 1930s, during Getúlio Vargas era, we watched the construction of a national development plan, from the establishment of a national industrial park. This movement caused deep changes into social Brazilian structure. Education, through Escola Nova movement, became the guide line of this transformation, fighting for the children's right to attend public school, besides presenting a new pedagogical model structured from this new attitude which claimed for a new space to reflect this renewal model of school.

The national development plan, at the cultural sphere, got together politicians and intelectuals to build a national identity, and architecture, meaning here the expression of a time, appropriated the rationalism of modern international architecture that, in the hands of young architects could find a rich field of experiment.

São Paulo is the scene of this movement, that in the mid of 1940s, was already an international metropolis and revealed in its urban space, the contradiction between richness and poorness, between center and outskirts.

The schools of the Convênio Escolar came to serve the districts which have, in the public school, the first sign of the presence of a State Government that, coming from the dictatorship of Getulio Vargas, start a new democracy phase. 


\section{CAPÍTULO I MODERNIZACÃO DO SISTEMA ESCOLAR: A IMPORTÂNCIA}

DA ARQUITETURA NA NOVA CONCEPÇ̃̃O PEDAGÓGICA

I.I Modernidade no Sistema Educacional Brasileiro:

Os Pioneiros da Nova Educação.

I.2 O Modelo de Escola Moderna derivado do Modelo Platoon americano

e sua aplicação no Rio de Janeiro, através do educador Anísio Teixeira

I.3 Modernidade na Educação do Estado de São Paulo:

O Código de educação de 1933 e a Comissão Permanente de Ensino

I.4 Modernidade na Educação do Município de São Paulo:

o Departamento de Cultura e Recreação e os Parques Infantis.. . .53

I.5 Os Convênios Escolares: $O$ diálogo construído entre o Estado

e o Município para a Ampliação da Rede Pública de Escolas... .61

I.5.1 O I Convênio Escolar (1943-1948)

1.5.2 O $2^{\circ}$ Convênio Escolar (1949-1953)

1.5.3 O $3^{\circ}$ Convênio Escolar (1954-1959) . .75 
2.I $\bigcirc$ contraditório contexto urbano de metrópole cosmopolita no qual a s escolas do $2^{\circ}$ Convênio foram implantadas... ...81

2.I.I A cidade se revela em suas contradições nos preparativos para a comemoração do IV Centenário da cidade paulistana

2.1.2 Os novos hábitos culturais paulistanos.........................................................................92

2.l.3 Os novos hábitos de morar na cidade paulistana .......................................................94

2.I.4 A SAGMACS e a revelação da cidade real..................................................................96

2.2 As definitivas influências da hegemônica arquitetura carioca........

2.2.I Breve histórico para compreensão da hegemonia da arquitetura carioca no cenário nacional ......

2.2.2 $\bigcirc$ papel de Oscar Niemeyer na afirmação de um vocabulário arquitetônico nacional

2.3 Referenciais profissionais: os exemplos de Affonso Eduardo Reidy

e Aluísio Nunes.....

2.3.I A inspiradora referência de Affonso Eduardo Reidy....

2.3.2 $\bigcirc$ exemplo do arquiteto Luis Nunes na gestão da diretoria

de Arquiteura e Construção do Estado de Pernambuco 
3.I O levantamento da situação do ensino na cidade paulistana e

as conseqüentes posturas iniciais adotadas............................................................................131

3.1.I Os trabalhos iniciais do $2^{\circ}$ Convênio Escolar ..........................................................135

3.1.2 $\bigcirc$ embasamento pedagógico aplicado às escolas

do $2^{\circ}$ Convênio Escolar .......................................................................................................... 137

3.1.3 Causas para o sucesso do $2^{\circ}$ Convênio Escolar .......................................................144

3.1.4 Arquitetura escolar experimental: a construção de conceitos

a partir da escala da criança .........................................................................................................146

3.1.5 Recomendações técnicas adotadas pela equipe de Hélio Duarte .......................150

3.2 Racionalização na produção seriada de projetos econômicos,

implantação e programa arquitetônico dos novos edifícios

para a educação: praças de serviços públicos nos bairros paulistanos.............................155

3.2.1 O programa arquitetônico de 12 salas de aula .........................................................159

3.2.2 Considerações com a cidade, o bairro e o entorno imediato ...............................162

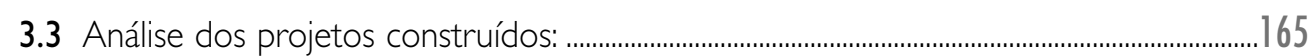

3.3.I Hélio Duarte e equipe: obras do $2^{\circ}$ Convênio em análise .......................................171

3.3.I.I Breve biografia de Hélio Duarte .....................................................................173 
3.3.2. I A equipe e os 52 projetos do $2^{\circ}$ Convênio escolar ...................................177

Arquiteto Hélio de Queiroz Duarte..............................................................179

Arquiteto Eduardo Corona................................................................................201

Arquiteto Roberto Goulart Tibau..................................................................215

Engenheiro Ernest Robert Carvalho Mange ................................................234

Arquiteto Oswaldo Corrêa Gonçalves ..........................................................246

Arquiteto Juvenal Watege e Arquiteto Aluísio Rocha Leão.....................259

Obras com autores não identificados...........................................................265

CONSIDERAÇÕES FINAIS

ANEXO .303

CRÉDITOS DAS ILUSTRAÇ̃̃ES .307

BIBLIOGRAFIA 


\section{"PRIMEIRO: ESCOLAS}

...Fazer escolas, fazer escolas, fazer escolas, está bem, fazê-las, o fato enquadrase em tentativas abstratas, em retumbantes decisões ministeriais: falta o interesse ardente, falta a dramaticidade da cousa. É necessário dramatizar o problema das escolas, torná-lo vivo, presente, cotidiano...

A premissa para edifícios construídos em função de sedes escolares, à primeira vista aparece transpor o problema arquitetônico, mas é pelo contrário a ele estreitamente ligado...

As formas que se expandem, que se ligam com o exterior, o jardim, as janelas largas, aquele ar de não severidade, é o primeiro passo para a abolição de barreiras. A escola fortim, gótica, normanda ou sem estilo mas com denominador comum de edifício-prisão lembrando quase aos alunos que o estudo é um penoso dever, esta escola tornou-se longínqua e obsoleta. E o próprio fato que arquitetos modernos tenham sido chamados para projetar todas estas escolas nos parece uma profecia. Comecemos pelas escolas e, sobretudo comecemos pela arquitetura."

(in Lina Bo Bardi, prefácio Revista Habitat n 4, São Paulo, set-dez de 195I) 



\section{INTRODUÇ̃̃O}

“... moderno nasceu como resposta a uma situação histórica, o moderno na arquitetura é um momento da história, uma tomada de posição permanente, fundada em princípios e métodos estabelecidos com relação aos problemas de seu tempo e apoiando-se no desenvolvimento científico e técnico mais avançado e na análise das necessidades e das possibilidades que a sociedade tinha para satisfazê-las. É com este sentido que o moderno poderia existir hoje - apesar dos efeitos contrários da moda, da mídia e da busca do lucro imediato - tornando-se de novo uma língua vivallinguagem atuante, uma causa, como foi durante o período entre Guerras e não um estilo como está reduzido por alguns." (in Kopp, revista AU, pág. 93, dez/jan de 87/88)

A arquitetura moderna brasileira, construída sobre bases sociais e humanistas, tem ainda muito a nos revelar, e seus atores, os arquitetos que enfrentaram as questões sociais e de desenvolvimento humano, como justificativa para sua profissão, não puderam, muitas vezes, registrar seus projetos da devida maneira: não havia tempo, as questões eram muitas e deveriam ser resolvidas com urgência.

Felizmente, foram muitos os arquitetos que abriram mão de sua projeção pessoal, dos elogios de uma crítica elitista e da elaboração de discursos articulados, em favor da prática consciente e do exercício constante do projeto arquitetônico. 
Esta pesquisa pretende colaborar nesse sentido: recuperar, no tempo e no espaço, um determinado grupo de arquitetos, que, visionário, e trabalhando em um órgão público municipal, conseguiu construir um conjunto de obras que, sem dúvida, pode ser chamado de legítima arquitetura moderna brasileira. Esse grupo não só se apropriou dos princípios acadêmicos do modernismo, mas também conferiu à arquitetura um valor social e humano inquestionável: um lugar apropriado para a educação, dentro de um projeto de desenvolvimento social do Brasil.

A arquitetura moderna do convênio escolar será abordada dentro dos princípios do modernismo, tal e qual foi teorizada por Anatole Kopp - "arquitetura moderna como causa e não estilo", e acreditando que o movimento moderno perdurará enquanto persistirem as injustiças sociais.

A questão social, assim entendida, foi a ossatura da arquitetura moderna, e é o que the dá suporte e a justifica, até hoje. As formas que o modernismo conferiu à arquitetura das escolas construídas pelo convênio escolar, naquele momento, atenderam às questões sociais que lhe foram postas como desafio: a construção do espaço da escola nova voltada para a criança e para a comunidade na qual estava inserida - a escola construtora da cidadania. A reflexão e o estudo desses edifícios escolares servem para que pensemos novas formas arquitetônicas, aproveitando aquilo que a equipe de arquitetos do convênio escolar alcançou: a racionalidade científica, que colocou o arquiteto como centro da produção do projeto, base para a construção dos edifícios escolares, tendo como meta a justiça social e o humanismo, um projeto coletivo em detrimento de vontades pessoais. 
“...Entretanto, as referências, as argumentações conceituais e as técnicas dos modernos não se esgotaram enquanto possibilidades, preservando o núcleo racional da criação arquitetônica. Trata-se de não desprezar os ensinamentos do passado e, ainda, não incorrer na subjetividade e no espontaneísmo da simples cópia como querem alguns." (in Kopp, revista AU, pág. 91, dezljan de 87/88)

Para o resgate das raízes do modernismo a serviço das causas sociais no Brasil, o recorte para a pesquisa, oferecido pela ação dos arquitetos do $2^{\circ}$ Convênio Escolar revelou-se expressivo, quanto ao quadro de desequilibrio social que se apresentava, no tocante ao oferecimento de vagas em escolas públicas entre 1949 e 1953. E tendo em vista a demanda por 48.000 vagas a serem oferecidas na rede pública de ensino, foram construídos 52 edifícios escolares, no município de São Paulo, cidade que despontava como o maior Parque Industrial da América Latina e que se dividia espacialmente entre uma cidade cosmopolita metropolitana, para alguns, e uma cidade ilegal e improvisada, para a maioria.

Cinco arquitetos e um engenheiro, coordenados pelo arquiteto Hélio de Queiroz Duarte, produziram todos os projetos arquitetônicos dessas 52 escolas, com racionalidade e princípios programáticos para que fosse uma escola libertadora, pensada a partir de uma pedagogia escolanovista, e resultando em uma nova arquitetura escolar, concebida para a escala da criança, com a finalidade de formar cidadãos em bairros que, até então, em sua grande maioria, eram desprovidos de qualquer equipamento público.

A produção arquitetônica do convênio escolar, enquanto forma arquitetônica, representou a introdução da linguagem moderna na arquitetura pública paulista, arquitetura nascida a partir dos preceitos de Le Corbusier e que ganhou os contornos 
orgânicos a partir da releitura dos jovens arquitetos formados pela Escola Nacional de Belas Artes, com destaque para Oscar Niemeyer. Essa arquitetura carioca, produzida no Rio de Janeiro, então Distrito Federal, espalhou-se pelo país, a partir dos arquitetos que, do Rio de Janeiro, saíram em busca de trabalho em todos os estados e também das novas faculdades de arquitetura que foram fundadas em várias cidades brasileiras. $\mathrm{Na}$ segunda metade da década de 40 e início da década de 50, a linguagem moderna carioca já estava consagrada como aquela que, culturalmente, expressava nossa brasilidade, reconhecimento que vinha inclusive da Europa e dos Estados Unidos após a Segunda Grande Guerra.

Este trabalho de finalização do Curso de Mestrado, ao eleger esse conjunto de escolas, expressão da moderna arquitetura carioca, pretendeu investigar a que essa nova linguagem arquitetônica servia, uma vez que foi resposta a um novo modo de pensar e produzir projetos arquitetônicos com uma finalidade social.

tema arquitetura escolar foi escolhido também em função de este pesquisador trabalhar com a produção de edifícios escolares junto à Fundação para o Desenvolvimento da Educação - FDE que, ligada à Secretaria de Estado da Educação de São Paulo, é responsável, entre outras atribuições, pela construção e manutenção física da rede de escolas estaduais. A rotina de trabalho que desenvolvo impõe ao técnico e arquiteto conviver diariamente com o dilema quantidade e qualidade, e as decisões e definições projetuais devem ser pensadas em função de uma rede de escolas e do grande número de estudantes que deverá ser atendido. Parte do meu trabalho cotidiano é fazer com que o arquiteto que presta serviços para a FDE na execução de projetos arquitetônicos, compreenda essa lógica, abrir mão de uma ou outra questão pontual de seu projeto, em favor da questão coletiva relativa à rede de 
escolas. A partir desse modo de pensar, que permeia minha rotina, é que encontro uma causa considerada moderna: dentro dos princípios da nova arquitetura abrir mão do projeto individual visando à construção do projeto coletivo, no caso a manutenção e a construção de uma rede de escolas públicas destinada a atender, com qualidade, todas as crianças do Estado, em que a arquitetura é só uma parte, complementada pelo projeto pedagógico.

As escolas construídas pelo convênio escolar vêm ao encontro dessa reflexão: foram erguidas cerca de 52 escolas em 5 anos, ou seja, pouco mais de 10 edifícios escolares por ano, quando a racionalização da construção ainda não existia na cidade de São Paulo. Dessa forma, a racionalização existiu somente na produção dos projetos: esses deveriam ser concebidos, considerando a construção em massa, em um curto espaço de tempo.

Fica a primeira questão a ser respondida: de que modo os arquitetos do convênio organizaram a produção de seus projetos arquitetônicos e por que a moderna arquitetura carioca prestou-se a essa produção em massa?

Parte do meu trabalho na FDE é coordenar projetos visando a intervenção em edifícios existentes e, por decorrência, acabei me deparando com os edifícios construídos pelo convênio escolar. Não conhecia ainda o conjunto dessas escolas, mas via uma grande semelhança entre vários edifícios construídos no final da década de 40 e início da década de 50 na cidade de São Paulo, que mostravam uma interessante unidade, configurando um conjunto.

Eram pilotis, grandes extensões de janelas, oferta de espaços livres ajardinados, recreios cobertos abertos, pés-direitos mais baixos que os convencionais, marquises sinalizando a entrada dos edifícios, coberturas em asa de borboleta, sem concreto 
aparente, sem malabarismos estruturais, nem mesmo grandes teorias e discursos, que estavam como que resguardadas do registro da história da moderna arquitetura paulista. Essas escolas estão, há 50 anos, espalhadas pela cidade, e se mostram muito diferentes do que eu havia aprendido e adotado como verdade no meu curso de graduação na Faculdade de Arquitetura e Urbanismo da Universidade de São Paulo - FAUUSP, na hegemônica arquitetura moderna paulista presente na formação de seus alunos.

Ao conhecer os primeiros exemplares das escolas do convênio, através de meu trabalho rotineiro procurei saber mais sobre aquele conjunto de escolas: eram as "escolas do convênio escolar do Hélio Duarte". Ao pesquisar, no arquivo da FDE, verifiquei que o conjunto das escolas construídas era muito mais expressivo, não só por sua qualidade arquitetônica mas também pela sua quantidade.

Conhecendo os primeiros exemplares, constatei que uma escola pública estadual ao lado de minha casa, no bairro da Lapa, que conhecia desde a infância, era uma das escolas do convênio, projetada por Hélio Duarte, a mesma que vi registrada em uma exposição da FAU, por ocasião de uma homenagem ao arquiteto, falecido em 1989.

Nas minhas recordações de infância estavam o espaço daquela escola, as salas de aula fartamente iluminadas, com corredores repletos de luz que passava através de uma infinidade de vidros quadriculados e um galpão abobadado, onde aconteciam as festas juninas do bairro. Conhecer essa escola com os olhos de criança foi fundamental para compreender as teorias acerca da escala aplicada na arquitetura escolar pelos arquitetos do convênio.

Fica, no entanto uma segunda pergunta: de que maneira e que diretrizes os arquitetos do convênio utilizaram para construir um programa e alcançar uma escala de espaço que prioriza a criança? 
A escola do convênio, da qual sou vizinho, chama-se EE José Monteiro Boanova. Implantada no bairro, abre-se para uma esquina que se prolonga para uma praça pública. A calçada entra na escola e continua até o bloco administrativo e o recreio coberto. $\mathrm{Na}$ entrada do bloco administrativo, encontra-se uma singela marquise demarcando a mudança da escala pública do espaço urbano para a escala da criança. O recreio coberto abobadado, também no prolongamento da calçada, recebe o visitante que, se adulto, quase encosta a cabeça na telha de cimento amianto que cobre os arcos. A escola, em sua implantação, convida e recebe seus estudantes e moradores do bairro.

Fica, ainda, uma terceira questão: essa generosa relação com o bairro foi uma característica que se repetiu em todo o conjunto de escolas do convênio?

Motivado pelas questões que acabei de colocar, iniciei minha pesquisa, construindo uma linha do tempo histórica, a partir das primeiras escolas republicanas, porque é a partir dessas escolas que tem início o projeto de construção de uma Nação através da educação - localizar o conjunto de escolas do convênio, no quadro de produção da arquitetura escolar paulista, pesquisar de onde vieram e de que forma foram aplicados os princípios que orientaram a produção desses espaços, foi para mim de suma importância.

A dissertação foi organizada em três capítulos:

No Capítulo I - Modernização do sistema escolar: a importância da arquitetura na nova concepção pedagógica - é relatada a importância do movimento escolanovista nas políticas educacionais do estado republicano, com ênfase na gestão de Anísio Teixeira junto à Secretaria de Educação e Cultura do Distrito Federal, quando reformulou o sistema escolar com base na nova pedagogia. Reorganizou aquele órgão 
público, ao implementar uma linha de ação baseada em estatísticas e procedimentos científicos. Ao lado do arquiteto Enéas Silva, projetou uma rede de escolas baseada nas escolas americanas Platoon, que se caracterizavam pelo ensino integral com disciplinas informativas (ensino tradicional) e disciplinas formativas (esporte, artes industriais, dança, teatro, biblioteca etc). Essa nova pedagogia levou à busca de uma nova arquitetura para o desenho de um novo edifício escolar - desde então, arquitetura e pedagogia passaram a caminhar lado a lado.

Em função dessa experiência e dos constantes esforços dos escolanovistas para a renovação do sistema educacional brasileiro, o estado de São Paulo, através da Comissão Permanente de Ensino passou a reformular a rede estadual e seus edifícios. Assim, os programas arquitetônicos passaram a contar com auditórios e bibliotecas e a atentar-se para as questões de higiene pública ao implantar seus edifícios, considerando como premissas as questões de aeração e insolação das salas dos diferentes ambientes.

Por sua vez, na cidade de São Paulo, um conjunto de edifícios denominados Parques Infantis, implantado por Mário de Andrade em sua gestão na Secretaria Municipal de Cultura, criou uma primeira referência para o ensino, complementar ao ensino ministrado na escola pública, através da formação cultural e educação para os hábitos de higiene e esportes. Mário de Andrade preocupou-se com a formação do espírito de brasilidade nas crianças.

Por fim, ainda, nesse primeiro capítulo, é colocado o que foram os três convênios escolares celebrados entre o Estado e o Município, em atendimento à crescente demanda por salas de aula no Município paulista.

Para a elaboração desse capítulo, alguns livros foram imprescindíveis e possibilitaram recuperar, na linha do tempo, a seqüência das iniciativas a favor do 
aperfeiçoamento do sistema escolar público e em decorrência, da arquitetura escolar. São eles: O Município de São Paulo e o Ensino Primário, de Carlos Corrêa Mascaro, 1960; Parques Infantis de São Paulo: lazer como expressão de cidadania, de Carlos Augusto da Costa Niemeyer, 2002; Arquitetura e Educação: Organização do Espaço e Propostas Pedagógicas dos Grupos Escolares Paulistas, 1893/197/ de Esther Buffa e Gelson de Almeida Pinto, 2002 e a dissertação de mestrado A Modernidade Oficial: a arquitetura das escolas públicas do Distrito Federal (1928-1940) de Beatriz Santos de Oliveira, 1991 e a tese de doutorado Arquitetura para Educação: escolas públicas na cidade de São Paulo (1934 - 1962), de Mário Henrique de Castro Caldeira, 2006.

Esta dissertação, no seu Capítulo 2, intitulado Contextos e Referências, traça para o leitor, em sua primeira parte, o panorama da cidade de São Paulo no momento da implementação dos convênios escolares: renovação de costumes de uma sociedade industrial que se tornava cosmopolita e registrava em seu espaço urbano não só as novas maneiras de morar, como também os novos hábitos adquiridos nos passeios à Cinelândia e aos museus paulistas. Os preparativos para a comemoração do IV Centenário da cidade de São Paulo, com suas obras de infra-estrutura, revelaram uma metrópole sem planejamento e sedimentando seu crescimento industrial na frágil base de uma cidade dividida entre pobres e ricos.

A periferia revelava-se e começava a fazer parte das preocupações dos políticos que, acabada a ditadura getulista, iriam passar por eleições para a conquista de seus cargos públicos. A burguesia industrial pontuou os espaços da cidade paulistana com modernidade, e o parque do Ibirapuera, projeto de Oscar Niemeyer, foi o símbolo desse desejo. Para a compreensão da cidade, na década de 50, foi imprescindível a leitura da tese de doutorado Metrópole e Urbanismo, São Paulo anos 50, de Regina Maria Meyer Prosperi, 1991. 
Nesse mesmo capítulo foi também, de fundamental importância, a fim de contextualizar o panorama arquitetônico no qual foram produzidas as escolas do convênio escolar, o resgate da gênese da arquitetura carioca, desde o racionalismo da moderna arquitetura internacional até a síntese de Niemeyer, celebrada com a construção do conjunto arquitetônico de Pampulha. Nessa parte, o livro Arquiteturas no Brasil: 1900 - 1990 de Hugo Segawa, 1999, orientou minha pesquisa.

Para que o leitor tenha referências das posturas profissionais que permearam o trabalho da equipe do convênio escolar e seu modo de produzir modernidade através da arquitetura, foram escolhidos dois arquitetos, estratégicos para compreendermos a arquitetura moderna enquanto resposta às questões sociais. São eles : Affonso Eduardo Reidy e Luis Nunes.

primeiro foi, declaradamente, referência para a equipe do convênio, por sua postura profissional e, como resultado formal arquitetônico; a escola do conjunto Pedregulho foi referência formal, que facilmente identificamos em várias escolas construídas em São Paulo. O livro Affonso Eduardo Reidy, organizado por Nabil Bonduki, 2000, foi esclarecedor para, através do detalhado relato de suas obras e posturas, compreender a moderna arquitetura brasileira fundamentada em bases sociais. $\bigcirc$ segundo arquiteto, Luis Nunes, foi apresentado, a fim de mostrar como a modernização das repartições públicas a serviço da população, e mais especificamente do departamento de arquitetura, foram estratégicos para a modernização do estado.

No Capítulo 3, esta dissertação é finalizada com a reflexão colocada no início desta introdução, através da análise dos projetos desenvolvidos pela equipe dirigida por Hélio Duarte, durante o $2^{\circ}$ Convênio Escolar: arquitetura moderna, enquanto resposta às necessidades sociais concretas. As posturas da equipe são destrinchadas de maneira 
a compreendermos de que modo a criança é priorizada no projeto de um edifício escolar, de acordo com a pedagogia escolanovista. Através de recomendações técnicas, são desvendadas as teorias científicas que pautaram o desenvolvimento dos projetos. E, por fim, com a apresentação dos desenhos de cada uma das escolas, pode-se visualizar o universo de soluções que se manifestaram através de um resultado que apresentou variedade na unidade: uma resposta às questões pedagógicas que a história da arquitetura escolar ainda não conseguiu repetir.

Foi de fundamental importância para a completude desta dissertação o livro Arquitetura Escolar Paulista: anos 1950 e 1960, organizado por Avany de Francisco Ferreira e Mirela Geiger de Mello, onde pude pesquisar todo o acervo de desenhos dos projetos das escolas do $2^{\circ}$ Convênio Escolar.

Uma dissertação na área de projetos não poderia prescindir de visitas aos edifícios estudados. Por isso, visitei dez escolas do universo das 52 construídas, localizadas nos bairros da Lapa, Tatuapé, Barra Funda e Bairro do Limão e projetadas por três diferentes arquitetos: Hélio Duarte, Roberto Tibau e Eduardo Corona. 

ARQUITETURA NA NOVA CONCEPÇÃO PEDAGÓGICA 
"O fim da escola - pontificava Cubberley - não é somente saber, mas saber enquanto útil; não somente disciplina mental, mas disciplina da vida toda; não uma cabeça cheia de fatos, mas uma cabeça cheia de idéias; não regras de procedimentos aprendidas, mas habilidade de se conduzir corretamente; não conhecimento das matérias que constituem educação cívica, mas capacidade de pensar sobre as coisas cívicas; não tanto um erudito quanto um produto bem educado.

A escola, como se vê, deixara de ser a casa onde se estudavam alguns assuntos especiais que, se dizia, preparavam para a vida, para ser... o lugar onde as crianças vivem e, diariamente, são postas em contato com as reais experiências industriais e sociais, da comunidade da vida, experiências que as educam e armam para os mais árduos problemas da existência adulta que as espera." (in, Hélio Duarte 1973, pág. I6) 
1.1 MODERNIDADE NO SISTEMA EDUCACIONAL BRASILEIRO: OS PIONEIROS DA NOVA EDUCAÇ̃̃O E A CONSTITUIC̦ÃO FEDERAL DE 1934 
O Brasil Republicano, até a década de 20, pouco avançou no campo da educação pública, no que diz respeito à sua modernização e à sua adequação para a nova sociedade urbana que se desenvolvia, reflexo daquilo que já acontecia no resto do mundo, a partir do acelerado processo de industrialização das cidades.

Apesar de destinarem seus majestosos edifícios neoclássicos para as escolas em suas praças centrais, em substituição às Igrejas, de acordo com a importância dada à educação em um regime republicano, o Estado pouco acrescentou em matéria de ensino para a grande maioria da população, que ao emigrar para as cidades não tinha oportunidades concretas de educação, seja pela exigüidade de oferta de vagas nessas escolas, seja pelo ensino intelectualista, verbalista e excludente que passaram a representar. As escolas na Primeira República eram para poucos.

"Na verdade, a escola, nos diversos graus, e o diploma interessam a todas as camadas sociais. Os latifundiários querem filhos doutores, não só para bem exercer as atividades políticas e Ihes dar prestígio social como também para enfrentar possíveis situações de ruína. As camadas médias (pequenos comerciantes, construtores, funcionários públicos mais graduados etc.) e os trabalhadores urbanos viam na escolarização dos filhos um meio de aumentar as chances de ingresso numa função burocrática das mais simples às mais prestigiadas, essas ocupadas, sobretudo pelos bacharéis, seguidos pelos engenheiros." (in Buffa, 2001, pág. 64)

A emigração do campo para as cidades e entre países, em função da demanda por mão-de-obra na indústria, exigiu que as cidades e novas formas de morar fossem repensadas para acolher os núcleos familiares e seus novos hábitos de vida, e as escolas modernas republicanas eram parte dessa invenção. 
Nesta perspectiva, a educação, através da escola, passa a ser fundamental na capacitação da mão-de-obra qualificada para a indústria, que exigia cada vez mais preparo e especialização, e para a formação dos novos extratos sociais, advindos da formação da burguesia industrial. Assim, desde a I ${ }^{a}$ infância, as crianças necessitavam aprender hábitos de higiene e desenvolver capacidades para a vida em grupo, reflexo da mobilidade e da inclusão social oferecidas pela vida urbana.

A ciência da pedagogia se desenvolve e se moderniza para atender a esta nova realidade. Segundo os pedagogos, já a partir da década de 20, passa a escola a ter o papel de ensinar a viver, muito mais do que somente instruir. As cidades, na perspectiva da sociedade industrial, passam a ser os espaços de aprendizado para a vivência em uma sociedade participativa. Podemos afirmar, dentro desta linha de raciocínio, que a educação e o urbanismo passaram a caminhar juntos com o advento da sociedade industrial - era necessário, na escola, aprender a viver nos espaços urbanos modernos e, desta forma, o espaço físico da escola pública passa a ser um importante espaço para a vivência dessa urbanidade.

"A arquitetura escolar haveria, pois, de simbolizar as finalidades sociais morais e cívicas da escola pública. O lugar de formação do cidadão republicano teria que ser percebido e compreendido como tal" (in Souza 1998, pág. 124)

A pedagogia como ciência no mundo todo e no Brasil passa a ser reformulada, conforme coloca Carlos Augusto da Costa Niemeyer em seu livro Parques Infantis de São Paulo, 2002, pág. 78: 
“... a exemplo de bem sucedidas experiências européias, serão aqui também introduzidas reformas educacionais de peso em boa parte dos estados brasileiros durante os últimos anos da década de 1920. Iniciado na Inglaterra, em 1918 , com as reformas educacionais realizadas por Lord Fisher e seu Educacion Act, o movimento reformador expande-se pela Áustria (1919), Prússia e Estados Alemães (1 922-1925), estes últimos sob a influência da constituição liberal de Weimar, atingindo, na seqüência, os demais países europeus, chegando à Rússia pós- revolução, considerada pelo educador Fernando de Azevedo como "a mais audaciosa e radical de todas as reformas que então se realizaram" (in Pena, 1987, págs. 32-3).

No Brasil, o novo ideário pedagógico influenciará diversas reformas educacionais, realizadas, inicialmente, nos estados de São Paulo (1922), por Sampaio Dória; no Ceará (1922-3) por Lourenço Filho; no Rio de Janeiro (1928) por Fernando de Azevedo; na Bahia (1928) por Anísio Teixeira, e em Minas Gerais (1928), por Francisco Campos. Essas reformas surgirão como o meio dinâmico requerido pelos intelectuais e educadores para iniciar o tão sonhado processo de transformação das mentalidades." (in Niemeyer, 2002, pág.78)

Os intelectuais brasileiros que promoveram essas reformas foram chamados de "Renovadores da Educação" - os escolanovistas - e denunciaram publicamente a situação calamitosa do ensino em nosso país. Para tanto, fundaram em 1924 a Associação Brasileira de Educação - ABE - que a partir de 1927, realizava, anualmente, Conferências Nacionais de Educação, a fim de discutir com todos os interessados a real situação na área da educação e a perspectiva de qualificá-la, a partir da troca de experiências, inclusive internacionais, propagadas pelo Escolanovismo. 
Os "Renovadores da Educação" foram chamados, a partir da década de 30, a colaborar com o Governo Getúlio Vargas, empenhado em transformar nosso país agrário em um país desenvolvido e industrial. Entre as várias iniciativas, Getúlio Vargas cria, em 1930, o Ministério da Educação e Saúde e, assim, pela primeira vez em nosso país, a educação contaria com uma pasta própria ao lado da saúde, com a qual, a partir daí, caminharia.

O plano de reformulação da educação, preparado pelos "Renovadores da Educação" para o Ministério da Educação e Saúde foi, entretanto, substituído por uma reforma do ensino superior e secundário, sem considerar sua contribuição.

Diante do fato, os educadores, em 1932, lançaram à Nação um manifesto conhecido como "Manifesto dos Pioneiros da Escola Nova", assinado por expressivas personalidades envolvidas com a questão (in Buffa, pág. 66). "Neste documento eram retratadas muitas mazelas do nosso ensino e também eram expostos princípios que deveriam nortear sua reformulação. Dentre esses, merece destaque a proposta de uma escola primária pública, universal, leiga, obrigatória e gratuita em consonância com a nova realidade do país; a proposição de uma escolarização adaptada às características regionais e a formação em grau superior de todos os professores." (in Buffa, págs. 65-66).

Entre os intelectuais e educadores que assinaram o manifesto, merecem destaque os educadores Anísio Teixeira, Secretário de Educação carioca que, na década de 30, implantou a primeira rede de escolas públicas no Rio de Janeiro, inspirado nas teorias do educador norte-americano Jonh Dewey e no modelo americano das Escolas Platoon, e o educador Fernando de Azevedo que colaborou com o governo de São Paulo quando, em 1933, empreendeu uma reforma do ensino e instituiu o "Código de Educação do Estado", com o objetivo de unificar toda a legislação escolar. 
Anos depois, conforme nos relata Esther Buffa, Fernando de Azevedo afirmou que esse Código fora elaborado dentro das diretrizes essenciais do movimento de reconstrução escolar. Ou seja, através de Fernando de Azevedo, o Estado de São Paulo contou com o que havia de mais avançado no tocante às discussões do ensino no que diz respeito às escolas públicas e à nova pedagogia internacional.

Os Pioneiros da Escola Nova, anos mais tarde, prepararam, de acordo com o solicitado pela ABE (Associação Brasileira de Educação), um texto com sugestões para o anteprojeto de lei a ser apresentado aos constituintes de 1934. Nesse texto, foi ressaltada a necessidade de construção de sistemas educacionais regionalizados, colocando a esfera estadual como a responsável pela implantação desse sistema, uma vez que os municípios encontravam-se ainda bastante defasados em relação à infraestrutura já disponível no Estado. Aventou-se, entretanto, a possibilidade de municípios mais abastados e adiantados poderem tomar a frente nesta questão. Os Pioneiros, assim, colocaram-se contrários à federalização dessas questões, uma vez que defendiam que somente as iniciativas e comprometimentos locais relativos à questão educacional poderiam construir sistemas educacionais legítimos e adequados às especificidades de cada localidade, considerando-se a extensão de nosso país.

"A competência da União se estende, entretanto à fixação do plano geral, à coordenação suprema das atividades educativas nacionais e ao exercício de uma ação estimulante, ampla e vigorosa. A União, tomando a si o estudo dos sistemas educacionais e mantendo um serviço permanente e autorizado de inquéritos, pesquisas e informações, atuará como uma poderosa força intelectual na direção da educação nacional" (in Mascaro, 1960, págs. 5 I a 53). 
A Constituição Federal de 1934, a primeira versão de nossa Carta Magna a incluir no seu corpo de disposições fundamentais um capítulo especial sobre a educação e o ensino no país, estabeleceu que, para a constituição destes sistemas educacionais, os recursos financeiros deveriam ser obtidos da seguinte forma: I0\% provenientes da União e Municípios e 20\% provenientes dos Estados, recursos esses advindos dos impostos arrecadados por cada uma das esferas de poder. Assim a proposta dos "Pioneiros da Educação" em colocar o Estado como esfera responsável pela implantação dos sistemas educacionais tornava-se viável. 
1.2 0 MODELO DE ESCOLA MODERNA NO BRASIL DERIVADO DO MODELO PLATOON AMERICANO E SUA APLICAÇÃO NO RIO DE JANEIRO PELO EDUCADOR ANÍSIO TEIXEIRA 
A Revolução de 30 ao destituir do poder central a oligarquia agroexportadora, e pretendendo implantar um plano nacional de desenvolvimento baseado na economia industrial, encontrou nos conceitos escolanovistas para a educação um tema que uniu as várias tendências políticas.

Em 1931, Anísio Teixeira, um dos principais protagonistas do movimento "Renovadores da Escola Nova", foi nomeado Secretário Geral de Educação e Cultura do Distrito Federal, durante a administração de Pedro Ernesto (1931 a 1936), em substituição a Fernando de Azevedo, após regresso de duas viagens de estudos aos Estados Unidos.

Anísio Teixeira deixa claro, desde o início, suas intenções como administrador público:

"Ele se dizia um democrata e um liberal convicto e não escondia sua profunda admiração pelo poder de organização e capacidade de progredir da sociedade americana. Aceitou o cargo, colocando-se como continuador do programa traçado por Fernando de Azevedo, mas, disposto a dar ao serviço de educação do Distrito Federal uma feição técnica e científica, que julgava ter sido minimizada por uma administração de caráter extremamente personalista." (in Oliveira, 1991 , pág. 1 36)

Dessa forma, Anísio Teixeira, ao assumir o cargo de Secretário Geral de Educação e Cultura do DF, propõe, utilizando-se metodologia científica, a renovação da administração pública, e implanta em sua Secretaria um sistema escolar, a fim de trazer para a máquina administrativa a eficiência do processo produtivo industrial. Esse processo deveria culminar em um produto de qualidade: a escola pública eficiente e universal. 
Anísio Teixeira, dessa maneira, não apregoava um sistema escolar estático, mas ativo, em constante mutação, de acordo com a dinâmica do desenvolvimento e coerente com a modernidade, e os princípios dos valores modernos de democratização dos ganhos da sociedade industrial.

O seu reconhecido humanismo científico - de resto, uma característica escolanovista - fazia-o avesso a organizações que pleiteavam as formas da uniformidade e da centralização porque estas eram, para ele, meios de morte e não de vida. Emperravam o vigor das iniciativas, desestimulando a transformação e impedindo o desenvolvimento. Para Anísio, a organização racional era aquela que buscava, na unidade de um "princípio", a singularidade de sua forma, e não na repetição literal de um arranjo de seus elementos. Este "princípio" era entendido como o conjunto de idéias comuns que derivavam da filosofia de vida moderna. Eram decorrentes, portanto, da razão científica e da razão moral (ética). Sendo assim, eram estas que, em última instância, regeriam os objetivos e finalidades de qualquer conduta, modelando os planos, no intuito de conferir-lhes uma unidade, mas preservando-lhes a especificidade. (in Oliveira, 1991, pág. 175 e 176).

O humanismo defendido por Anísio Teixeira coloca o aluno como o elemento central da organização do sistema escolar. É pelo aluno que o sistema escolar deveria sempre ser visto e revisto, em um equilíbrio dinâmico. Conhecer a heterogeneidade dos alunos é fundamental para preservar esse equilibrio, principalmente em um país com nossa extensão territorial. As escolas, em sua organização espacial deveriam refletir esse humanismo; o espaço destinado à criança deveria ser adequado para trabalhar suas sensações e atender às suas necessidades de conforto acústico, térmico, psicológico, a fim de garantir o seu melhor desempenho pedagógico. 
A rede de escolas proposta por Anísio Teixeira inseriu-se no Plano Urbanístico de Alfred Agache, recém implantado no Rio de Janeiro, e o modelo ideal de edifício escolar adotado foi inspirado nas escolas americanas tipo Platoon, modelo esse já experimentado nos Estados Unidos, em um momento de crescimento e estruturação da rede pública de escolas norte-americanas que Anísio Teixeira conheceu de perto em suas viagens de estudo.

O que impressionou o educador Anísio Teixeira, ao conhecer de perto tal experiência, não foi somente a grande oferta de edifícios escolares construídos, mas, sobretudo, a qualidade de ensino oferecida através de escolas de período integral, nas quais os alunos iam muito além das "letras e dos números", vivenciando atividades culturais, esportivas e de lazer como parte fundamental de sua formação.

"As escolas construídas no Rio de Janeiro, neste período, carregavam o estigma de serem vitrine da política educacional pretendida para o restante do país, portanto, têm de ser necessariamente vistas sob a ótica da reprodução de um discurso, materializado em uma forma que se pretendia modernizadora, mas também carregada da afirmação de um estado que fosse capaz, junto a uma nova proposta pedagógica, de inserir a criança e o adolescente em um modo de vida que até então muito poucos tinham acesso." (in Caldeira, 2006, pág. 4I).

O conjunto de escolas a ser construído deveria, portanto, ser planejado estrategicamente, levando-se em consideração, para a sua concretização, a realidade brasileira, consideradas suas especificidades e realidades regionais. Para tanto, foram criadas seções dentro da Secretaria de Educação e Cultura, com o propósito de 
auxiliar no conhecimento de nossa realidade escolar: seção de recenseamento, matrícula e freqüência; seção de estatística escolar; seção de antropometria; seção de medidas e eficiência escolares, entre outras (in Oliveira, 1991, págs. 141 e 142).

Para poder implantar esse modelo no Brasil, Anísio precisou conhecê-lo, precisou buscar nossa identidade, e todo o Governo Federal, viu-se envolvido nessa busca, uma vez que a mudança pretendida para o Brasil só poderia acontecer em bases concretas, seguras, e só uma metodologia investigativa poderia garantir o sucesso do projeto de desenvolvimento nacional pretendido.

Como conseqüência dessa decisão, data de 1931 a criação do Instituto Brasileiro de Geografia e Estatística (IBGE), realizada em um Congresso da Associação Brasileira de Educação (ABE), reduto escolanovista, o que evidencia a seriedade e a profundidade como era considerada a questão educacional. Começou-se a partir daí, a discussão da importância das estatísticas e a escolha do padrão metodológico a ser adotado para as pesquisas e quantificações necessárias para o planejamento do sistema escolar a ser implantado pela Secretaria de Educação e Cultura. $\bigcirc$ levantamento e análise de nossas condições eram uma necessidade proporcional ao desejo de modificar a face do país. (in Oliveira, 1991, pág. 143).

Foram essas estatísticas que mostraram a Anísio Teixeira a carência e a precariedade dos edifícios escolares. Como grande defensor da arquitetura escolar, enquanto promotora das bases físicas para o progresso do sistema educacional, concluiu que um novo projeto pedagógico só se sustentaria com uma nova maneira de pensar a escola, e à arquitetura caberia projetar um novo edifício, um novo programa arquitetônico que refletisse, no conjunto de seus ambientes, essa pretendida nova maneira de ensinar. 
"Esse era, sem dúvida, um ponto de vista característico da Escola Nova. Boa educação era um direito de todos e precisava de boa arquitetura para realizar-se, portanto, boa arquitetura escolar era direito de todos os cidadãos. O sentido da instrumentalização da arquitetura para ganhos pedagógicos concretos, e não para alcances puramente estéticos e propagandísticos, estava presente nas realizações dos reformadores escolanovistas, mesmo quando discordavam quanto ao que fosse bom ou não em arquitetura de escolas." (in Oliveira, 1991)

As primeiras escolas construídas na gestão de Anísio Teixeira, cujos projetos arquitetônicos foram de autoria do arquiteto Enéas Silva, inauguraram a iniciativa, no Brasil, de se construir uma rede de escolas com uma proposta pedagógica sintonizada com uma nova filosofia de educação pública, uma escola formadora de hábitos, alinhada com as mudanças pelas quais passava o país da era Getulista. A escola pública deveria ganhar da "rua" a disputa pelo tempo das crianças em relação à sua educação.

As escolas modelo "Platoon", adotadas por Anísio Teixeira, caracterizavam-se, formalmente, pela disposição de seus blocos de salas em pelotões. $\bigcirc$ primeiro pelotão seria destinado ao ensino tradicional com salas de aula para instrução das letras e números, através das disciplinas fundamentais (ou home-room-subjects), e o segundo pelotão (ou special-subjects), para as atividades especiais, formativas e complementares de artes, esportes, higiene, biblioteca, atividades manuais e industriais etc.

Os estudantes nessas escolas permaneceriam em horário integral, entrando no início da manhã e saindo ao final da tarde. As crianças que na parte da manhã desenvolviam atividades de instrução, à tarde participavam das atividades formativas; por sua vez, a turma que de manhã tinha atividades formativas, à tarde desenvolvia atividades de instrução. Assim o uso intensivo dos espaços viabilizava economicamente 


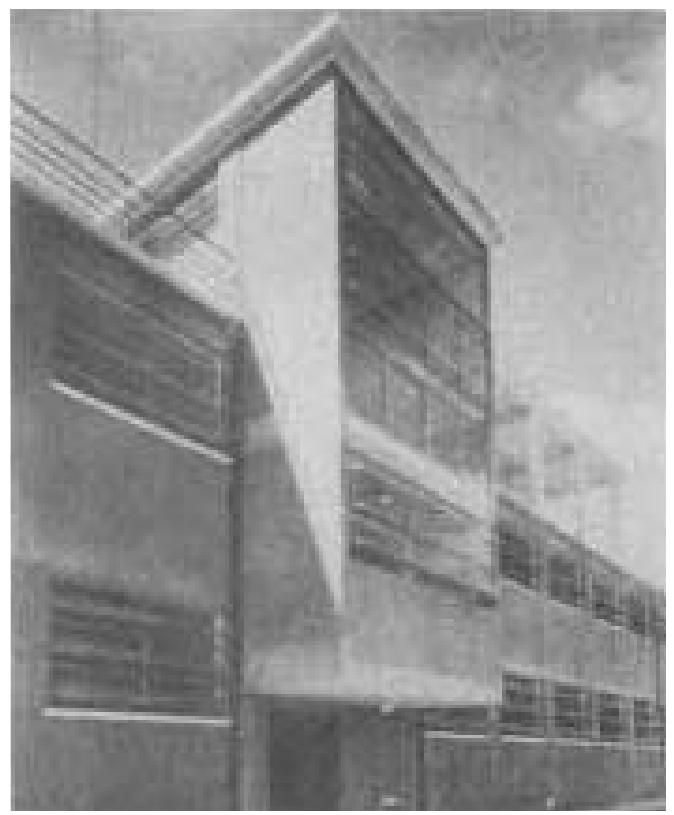

PLATO0N 16 CLASSES, ENTRADA POSTERIOR

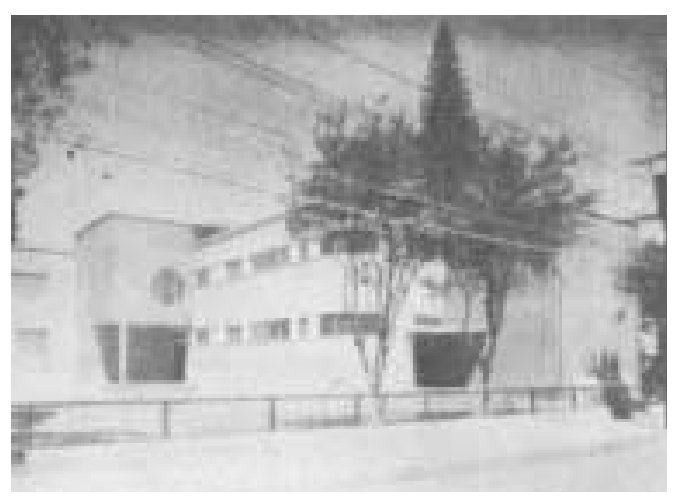

PLATOON 16 CLASSES, PERSPECTIVA essas escolas. Cada pelotão poderia ser equiparado a uma linha de produção industrial, em que a "matéria-prima aluno" entraria na I a sala para sair formado integralmente pelas últimas salas do pelotão.

O educador Anísio Teixeira, ao conhecer as escolas Platoon, em Detroit, nos Estados Unidos, impressionou-se pela maneira como o trabalho manual era valorizado na educação do povo americano, enquanto o povo brasileiro ainda associava o trabalho manual ao trabalho escravo, característica essa que a sociedade brasileira, comprometida com um futuro industrial, deveria repensar e modificar. $\bigcirc$ modelo Platoon de escolas apresentava como proposta central unir o pensar ao fazer ou o pensar e o viver ativo em um mesmo espaço físico.

Essa tipologia de edifícios, entretanto, exigia grandes terrenos para sua implantação, uma vez que haveria salas de aula clássicas, ou do ensino elementar, e ginásios, auditórios, bibliotecas, oficinas características do ensino especial. Terrenos com o porte necessário para essas escolas eram poucos, o que comprometia o modelo Platoon como modelo oficial a ser implantado.

De espírito objetivo, já que buscava atender à realidade que the era imposta, Anísio Teixeira criou dois modelos de escola que interagindo, ganhariam a completude pretendida pelas escolas Platoon. Eram as escolas-classe (somente classes para o ensino fundamental) e as escolas-parque (espaços para o ensino especial) e a combinação dessas duas tipologias, onde quatro escolas-classe se complementariam com uma escola-parque, adequar-se-iam ao modelo Platoon pretendido.

Desse modo, Anísio Teixeira encomendou aos arquitetos seis tipos de projetos de escolas, que, gradativamente, buscavam atender aos ideais da escola de ensino integral: 
— Escola Tipo Mínimo (240 alunos): 2 salas de classes fundamentais e I sala de classe complementar, a serem implantadas em áreas de reduzida demanda por escolas.

— Escola Nuclear ( 1.000 alunos): 12 salas de classes fundamentais com biblioteca para os professores.

- Escolas - Parque ou Parques escolares que atenderiam, cada um, ao conjunto de quatro escolas nucleares, complementando seu programa arquitetônico de acordo com o modelo Platoon: direção geral; serviço médico e fichamento para controle de educação física; auditório e palco; ginásio esportivo; banheiros e vestiários; refeitórios e anexos (copa, cozinha, serviços); sala de música; jardim de infância; biblioteca; salas para clubes escolares; sala para projeção; terraço-jardim; estádio para concentração e pista de corrida; campos para voleibol ( 4 pequenos campos); equipamento completo para ginástica e playground.

- Escolas Platoon com 12 classes, 16 classes e 24 classes, sendo que as de 12 e as de 16 classes necessitariam das escolas-parque para complementar seu programa arquitetônico para o ensino integral.

- Platoon 12 classes: 6 classes para o ensino fundamental e 6 classes para o ensino complementar, com salas para leitura e literatura, com biblioteca anexa; ciências sociais; ciências, com respectivo "vivarium"; desenho e artes industriais; auditório; música, recreação e jogos; - Platoon 16 classes: 12 classes para o ensino fundamental; 4 classes para o ensino complementar: ciências e ciências sociais; música, recreação e jogos; auditório;

- Platoon 24 classes: 12 classes para o ensino fundamental e 12 classes para ensino complementar: biblioteca; ciências sociais; ciências; desenho e artes industriais; auditório com palco; música;recreação; jogos; ginásios; refeitório e anexos correspondentes; almoxarifado escolar; salas de professores. 


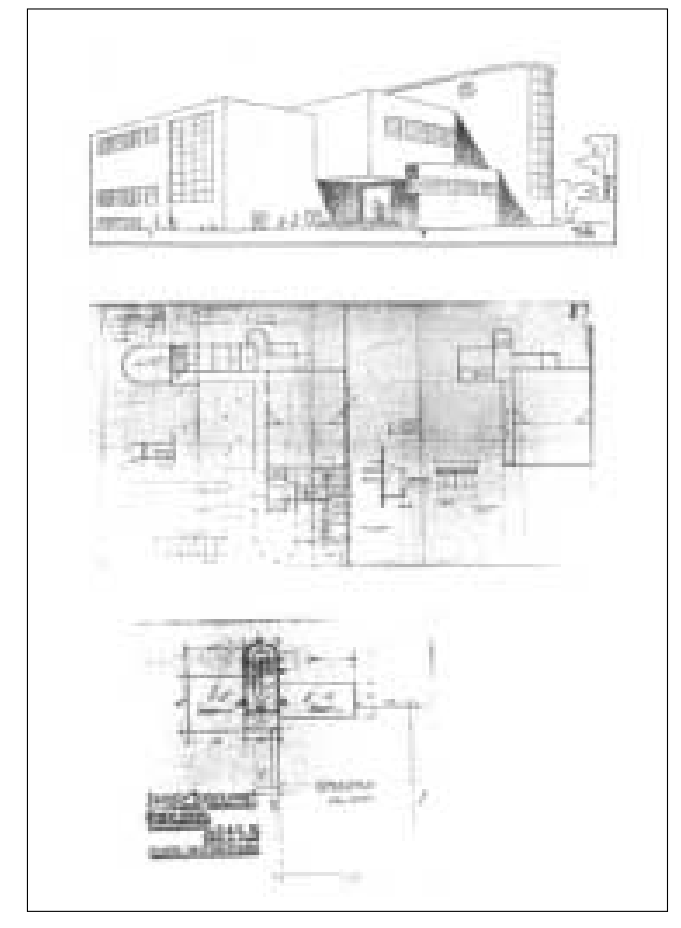

ESCOLA-PARQUE

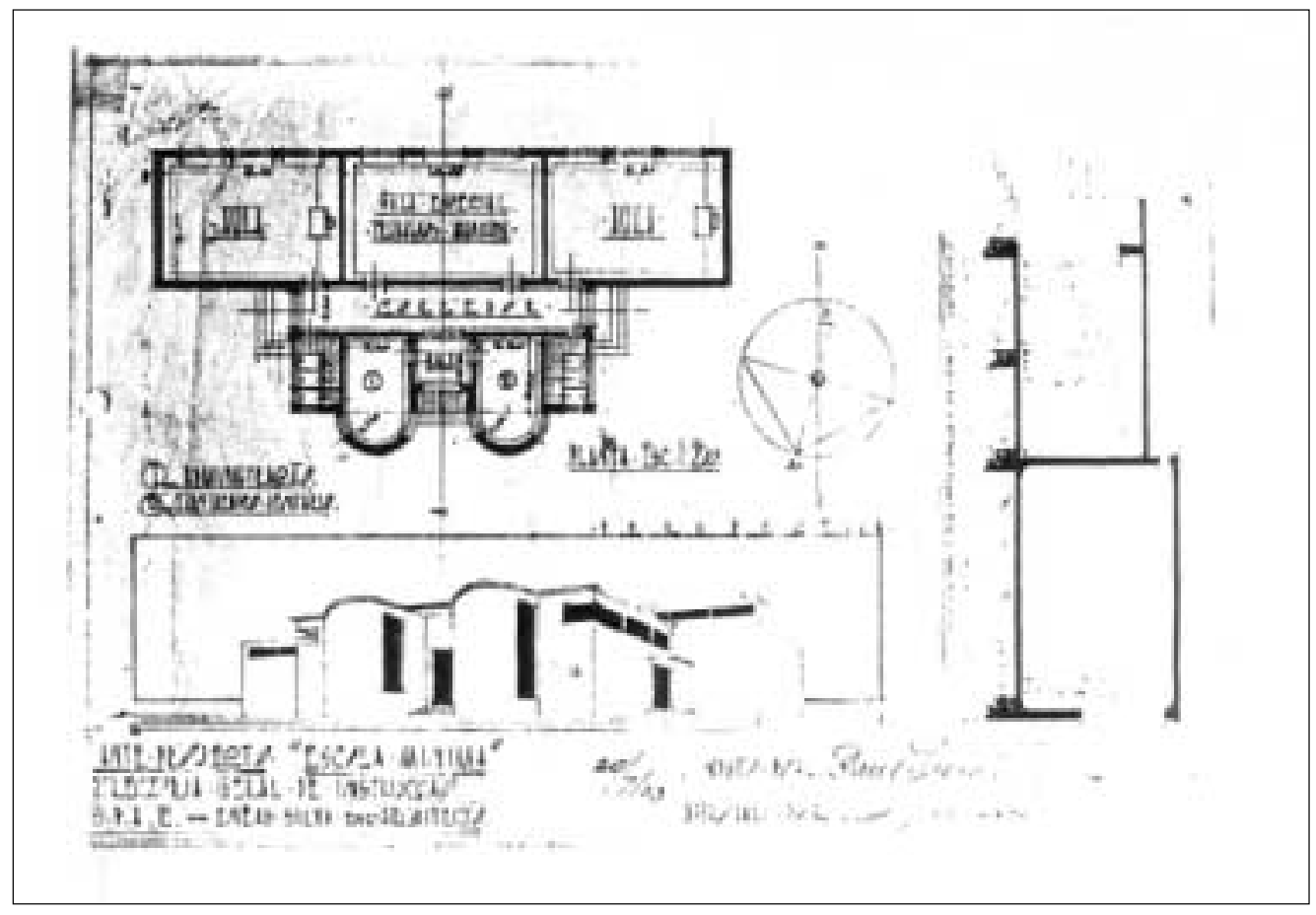

ESCOLA-MÍNIMA 


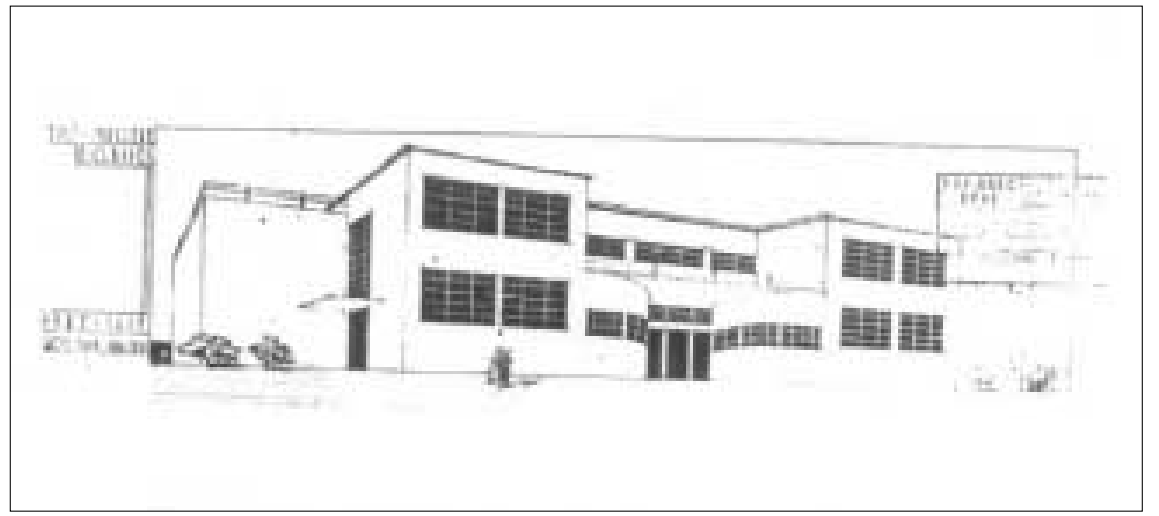

PERSPECTIVA NUCLEAR 12 SALAS

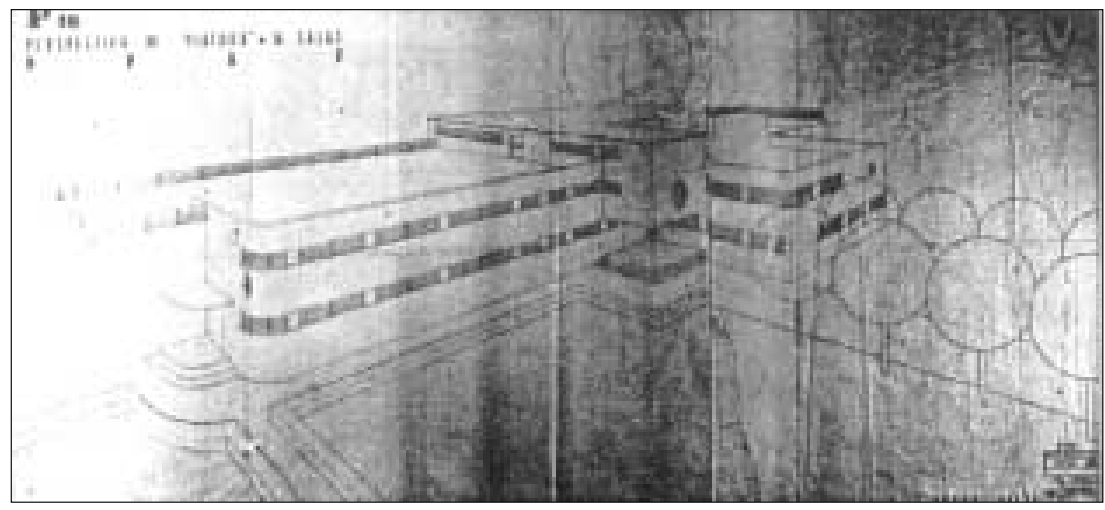

PERSPECTIVA PLATOON 12 SALAS

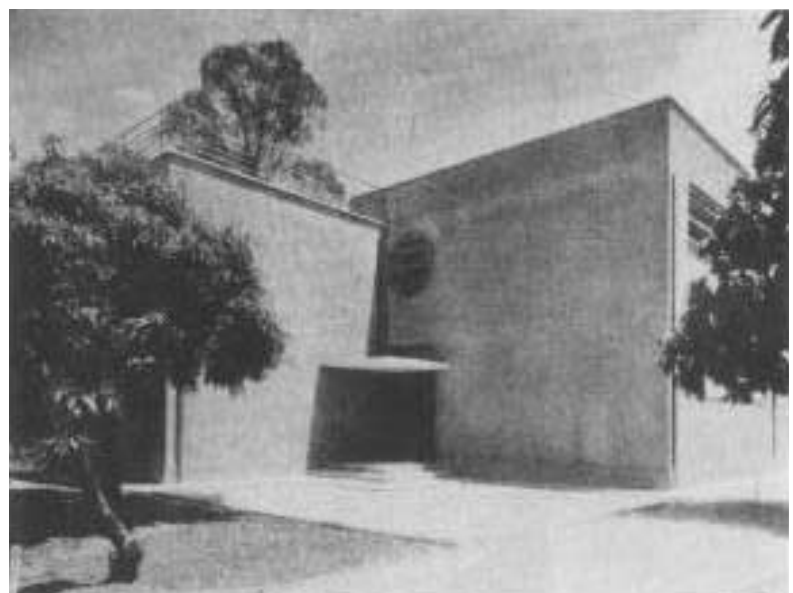

NUCLEAR 12 CLASSES, ENTRADA LATERAL 


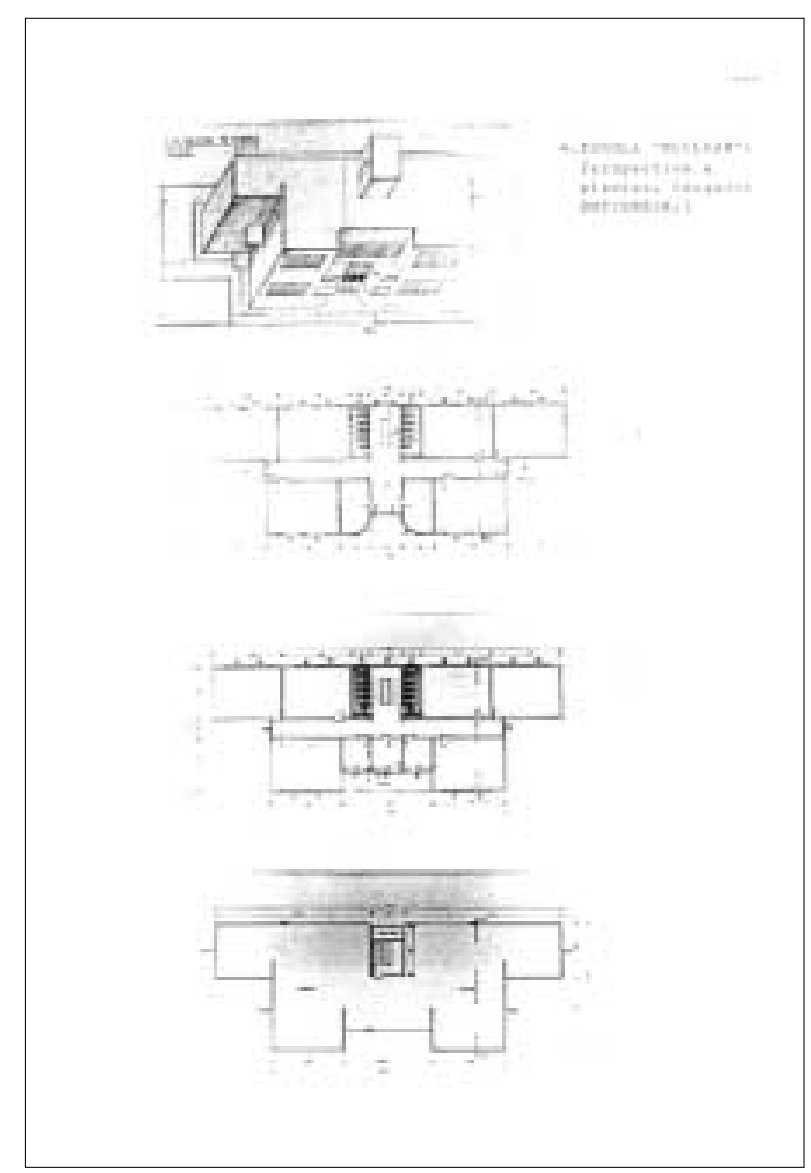

ESCOLA NUCLEAR - PERSPECTIVA E PLANTAS

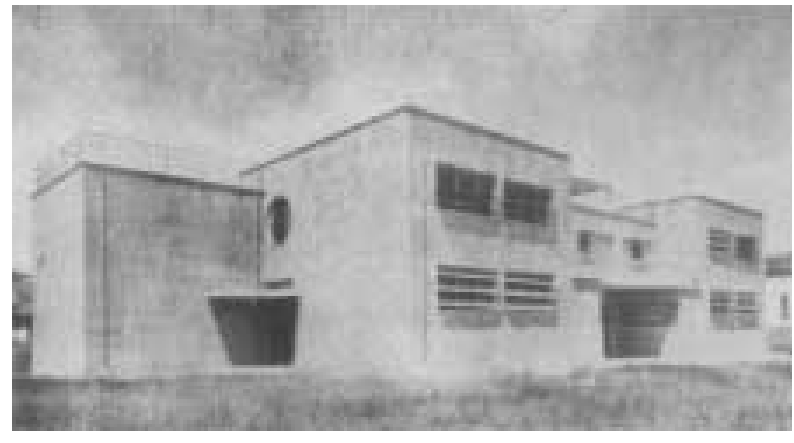

NUCLEAR 12 CLASSES, PERSPECTIVA

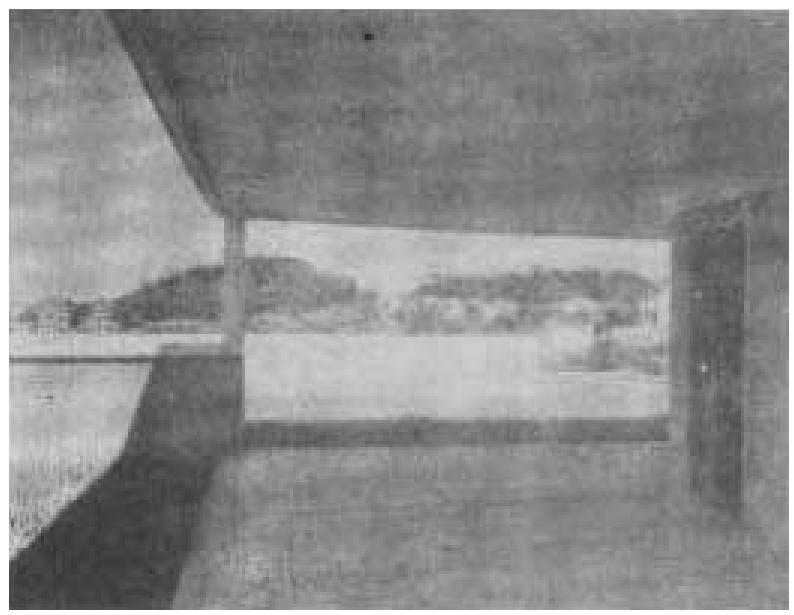

NUCLEAR 12 CLASSES, TERRAÇO JARDIM 
O comprometimento do educador com a busca, na educação, de uma identidade nacional encontra no discurso dos arquitetos modernos brasileiros o mesmo comprometido discurso que, entretanto, engatinhava enquanto resultado formal.

A arquitetura brasileira, nesse momento, como em todo o mundo, buscava se reposicionar na sociedade, apresentando-se através do domínio da técnica projetual e construtiva, tão cara a uma sociedade industrial.

Os hábitos que a escola pretendia transformar redesenharam também os espaços necessários ao homem moderno. Esses espaços precisavam ser desenhados, construídos, agora não mais com uma finalidade meramente estética, o que cabia ao arquiteto clássico no uso da cartilha de estilos, mas ao arquiteto técnico e construtor, que domina os processos construtivos. $\bigcirc$ profissional arquiteto passa a fazer parte do processo produtivo, com o papel de dimensionar os espaços, seu desempenho e sua técnica construtiva, através de dados científicos. Assim, justificativas projetuais, tais como as teorias dos educadores escolanovistas, passavam na mão dos arquitetos por análises científicas, pautadas em números e estatísticas.

Junto com o educador Anísio Teixeira, arquitetos como Enéas Silva constroem escolas e um discurso ético para justificar sua arquitetura, em que o pensar arquitetura e o fazer arquitetura se fundem em um mesmo ato, e projetam pensando em como construir, pois, as escolas precisam de eficiência, precisam mostrar resultados espaciais funcionais, concebidas que foram a partir de um projeto pedagógico transformador e preciso. Os arquitetos, sobretudo com a arquitetura escolar, passam a estar a serviço de uma nova ordem social e colocamse com um claro desejo de ser instrumentos de transformação da sociedade. 
Na sua dissertação de mestrado, Beatriz Santos de Oliveira descreve o texto do arquiteto Enéas Silva, datado de 1935 e publicado na revista da Prefeitura do Distrito Federal. Neste texto, encontramos as justificativas técnicas que balizaram a concepção de uma escola tipo Nuclear com 12 salas de aula e que exemplificam o comprometimento da arquitetura com a precisão do discurso pedagógico. Enéas coloca a necessidade de o arquiteto, comprometido com a arquitetura escolar, pesquisar, indo além das questões construtivas e assumindo compromisso com as questões educativas, levando-se em conta as questões biológicas e psicológicas da criança, sua mentalidade, maneira de viver, agir e julgar as coisas e, conseqüentemente, concretizando na arquitetura os princípios de segurança, salubridade, expansão, flexibilidade, conveniência, aspecto arquitetônico e economia, características essências de eficiência de um prédio escolar.

Enéas descreve com precisão os cuidados para com a orientação solar dos ambientes destacando, as caixas de escada para circulação como fontes de luz natural. $\bigcirc$ sistema estrutural proposto deveria ser em concreto armado, incluindo suas fundações, com vedações em alvenaria de blocos cerâmicos alveolares para isolamento térmico e acústico, e as lajes em concreto armado, cuja cobertura deveria ser impermeabilizada e receberia uma camada de $15 \mathrm{~cm}$ para isolamento térmico, com a finalidade de garantir seu uso como terraço jardim para as aulas de educação física ao ar livre. As janelas seriam desenhadas com caixilhos de ferro basculantes, a fim de garantir abertura total para ventilação dos ambientes. A disposição das salas, uma ao lado da outra com estrutura de concreto independente das vedações, garantiria a possibilidade para futuras mudanças, e - bloco de salas de aula permitiria a sua ampliação nas duas extremidades. A volumetria final, descreve Enéas Silva, seria singela e resultado da funcionalidade de sua planta. Sua 
linguagem arquitetônica é, assim, resultado direto da eficiência, otimização e conforto de seus espaços e custos de construção.

O discurso do arquiteto reflete seu comprometimento com a técnica, em que a plástica passa a ser produto dessa preocupação. A arquitetura moderna brasileira caminha no sentido de substituir sua condição de artista inspirado para a de agente de transformação social.

Anísio Teixeira, dessa forma, se identificava e se aproximava dos arquitetos modernistas brasileiros, que, como ele, buscavam, através da construção de novos programas, respostas para as novas necessidades sociais, baseadas na ciência e na razão, uma vez que funcionalistas e racionalistas poderiam responder com novas formas às carências do povo brasileiro e, em especial, às dos educadores com a construção de edifícios voltados à educação e à cultura Uma nova forma, entretanto, ainda estava por ser desenhada para expressar este movimento.

Assim, as escolas criadas no Rio de Janeiro por Anísio Teixeira e Enéas Silva são uma forte referência que irá permear as teorias de todos os educadores e 0 discurso ético dos arquitetos. A partir de então, a união entre essas duas áreas do conhecimento passa a ser fundamental para a qualidade da educação em nosso país.

Há que se ressalvar que o conjunto de escolas construído nesse período não é a expressão plástica de nossa moderna arquitetura brasileira, pois são ainda criadas dentro das regras da Art-Decô, a partir de elementos que evocam a máquina, a arquitetura naval, a velocidade e a aerodinâmica, respostas formais a um modismo que evocava o futuro.

Esses projetos aproximam-se da arquitetura moderna, demonstrando coerência em suas plantas funcionais, conseqüência dos inovadores programas das 
escolas de ensino integral, e a necessária economia de recursos para sua construção além do racionalismo programático com o qual foram concebidos. Assim, a eficiência dos ambientes, sua funcionalidade e o discurso ético é que lhes confere este pioneiro papel de modelo para as escolas modernas que serão construídas no país, principalmente em São Paulo, através da Comissão Permanente, pelas mãos de arquitetos como José Maria da Silva Neves e Humberto do Val Penteado. 
1.3 MODERNIDADE NA EDUCACÃO DO ESTADO DE SÃO PAULO: 0 CÓDIGO DE EDUCAÇÃO DE 1933 E A COMISSÃO PERMANENTE DE ENSINO 
As primeiras escolas construídas na cidade de São Paulo, a partir do espírito de renovação e modernidade apregoado pelos "Renovadores da Escola Nova", foram empreendidas pela Comissão Permanente de Ensino, por iniciativa do Estado. Essa Comissão foi instituída pelo Código de Educação do Estado, datado de 1933 e organizado pelo educador Fernando de Azevedo, que o destacou no capítulo intitulado "Do serviço de prédios e instalações escolares", com o objetivo de:

"propagar a nova política das construções escolares, ampliando em todas as camadas sociais a consciência da necessidade de cada escola possuir instalações pedagógicas que façam dela centro de saúde e alegria, ambiente de educação estética e fator de nacionalização" (Artigo 32).

É importante salientar que o Estado de São Paulo, a partir da Revolução de 1932, firmou, perante a Nação, seu compromisso com o desenvolvimento e a modernidade, e, assim, a educação mereceu seu devido e estratégico destaque neste processo.

Até então as escolas construídas na Primeira República pelo Departamento de Obras Públicas (DOP) do Estado representavam uma nova condição para a educação da sociedade, na possibilidade que ofereciam de formar o cidadão republicano. As majestosas escolas neoclássicas colocaram o edifício escolar como protagonista do espaço urbano; com a chegada de um novo tempo, porém, reduziram-se a edifícios com o simplificado programa de um conjunto de salas de aula, organizadas em duas alas simetricamente divididas, uma para cada sexo, pátio para recreação, uma pequena administração e sanitários. A educação era nessa primeira fase da República para poucos.

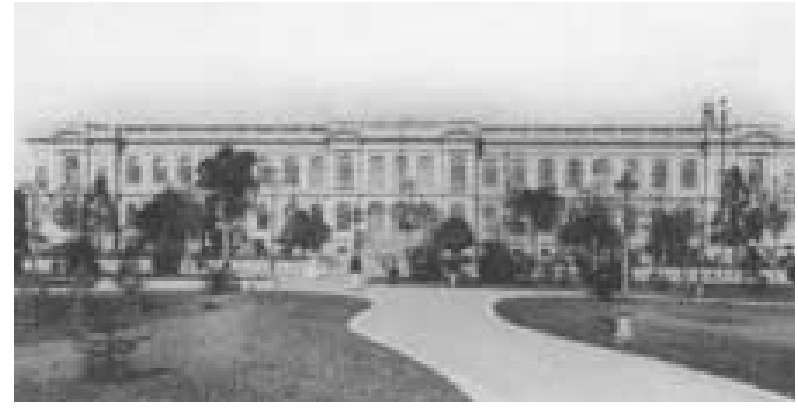

ESCOLA NORMAL CAETANDO DE CAMPOS - RAMOS DE AZEVEDO

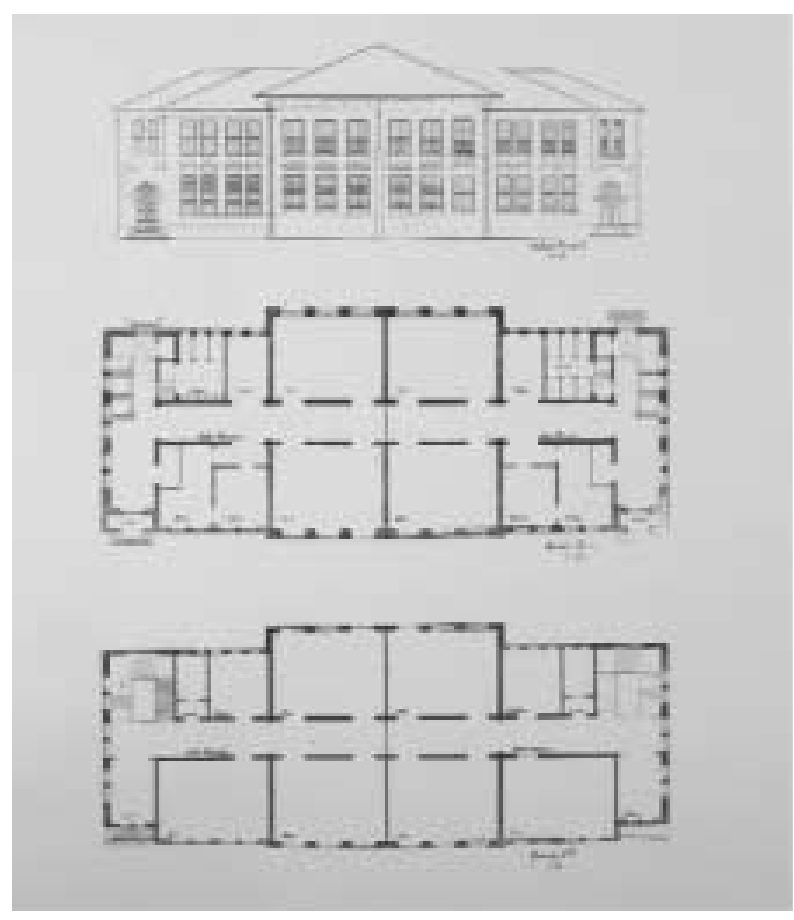

ESCOLA PADRÃO VILA MARIANA - RAMOS DE AZEVEDO 
As escolas da Primeira República representavam, na vida dos estudantes, momentos de instrução intelectualista e verbalista. Eram em pouco número, e por isso somente privilegiados tinham direito a esse serviço público. Na maioria das vezes, nem o programa mínimo era atendido, e a situação dos professores e estudantes era bem pior, uma vez que contavam unicamente com espaços improvisados em edifícios alugados, sem condições mínimas de salubridade para as atividades pedagógicas.

As escolas construídas pela Comissão Permanente de Ensino inauguraram a modernidade na arquitetura escolar em nosso Estado. Importa frisar que essas escolas carregam a experiência trazida do Rio de Janeiro, então Capital do país que, como já vimos anteriormente, implantou a primeira rede de escolas com o espírito de modernidade, através de iniciativa do educador Anísio Teixeira.

A Comissão Permanente, para efetivar o planejamento da rede de escolas do Estado, além de contar com a referência das escolas-classe e escolas-parque e o modelo Platoon da rede pública do Rio de Janeiro, contou, para o seu planejamento, com os dados coletados pelo Censo Escolar de 1934. Os dados técnicos e a ciência começavam a fazer parte também do planejamento da rede escolar paulista.

○ Censo Escolar revelou em números para o Estado de São Paulo a já conhecida e calamitosa situação do ensino público de nosso país, denunciada pelos "Pioneiros da Escola Nova": contabilizou-se nesse censo uma população escolarizável de |.|37.09| habitantes entre 7 e 14 anos, com uma população urbana de 38,36\% e rural de 61,64\%. Os números finais do censo revelaram que mais da metade da população escolarizável não freqüentava a escola - (62,07\% ou seja 705.793 habitantes) e revelaram também que a situação já preocupante nas cidades era pior ainda na área rural. A falta de edifícios específicos para a educação era apontada com veemência 
no resultado apresentado. A partir dessa constatação, o Governo do Estado encomendou à Diretoria de Ensino recém criada, órgão ligado à Secretaria dos Negócios da Educação e Saúde Pública, um plano de edificações e adaptações de escolas, que resultou no livro publicado em 1936, intitulado "Novos Prédios para Grupo Escolar", com a finalidade de subsidiar sua política educacional, no que tange à expansão de sua rede de escolas.

A Comissão Permanente formada contava com técnicos de duas Secretarias Estaduais (Secretaria da Educação e Saúde e Secretaria da Viação e Obras Públicas) e era constituída por uma equipe multidisciplinar de notáveis profissionais, o que demonstra a importância dada à questão da educação no Estado nesse momento. Dessa comissão participavam arquitetos, engenheiros, administradores, professores, médicos e higienistas, nomes expressivos como Antônio de Almeida Júnior - exchefe do serviço de higiene escolar, Francisco de Prestes Maia - engenheiro chefe do escritório técnico da diretoria de obras públicas, José Maria das Neves - chefe da seção técnica de projetos de grupos escolares, Carlos Alberto Gomes Cardim Filho - chefe da divisão de urbanismo da prefeitura da capital, Oscar Machado de Almeida - diretor de obras públicas, Luis Motta Mercier - chefe dos serviços de prédios escolares da Diretoria de Ensino, Geraldo de Paula Souza - diretor do Instituto de Higiene, Figueira de Mello - inspetor chefe da Inspetoria de Higiene Escolar e Educação Sanitária, Danton Malta - inspetor médico escolar,Vicente de Sampaio Lara - médico instrutor do Instituto de Higiene, Moacir Álvaro Eyck - médico oftalmologista, Noemy Silveira Rudolfer - professora de psicologia educacional do Instituto de Educação, Quintiliano José Sitrangulo - Delegado Regional de Ensino, Carolina Ribeiro - diretora do curso primário, Milton da Silva Rodrigues - professor 
de estatística e educação comparada do Instituto de Educação e Jorge Mancebo desenhista arquiteto da Diretoria de Ensino. (in: Novos Prédios para Grupos Escolares, 1936, págs.37 e 38).

A composição da Comissão, tendo em vista o expressivo número de médicos e higienistas nos dá a dimensão da preocupação do Estado com as questões de saúde pública, questões essas que passaram a ser consideradas nos desenhos dos projetos dos novos edifícios escolares. Assim, novos ambientes foram propostos para atender ao programa arquitetônico das novas escolas, a fim de abrigar no edifício escolar o médico sanitarista, o dentista e a colocação dos vestiários para promover o hábito de banho nos alunos.

A Comissão Permanente caracterizou-se por promover discussões multidisciplinares. Assim, reuniões promovidas pelo Secretário de Educação, para discutir questões relativas ao edifício escolar, contavam com as diversas áreas de conhecimento ligadas às questões educacionais. No livro "Novos Edifícios para Grupo Escolar", algumas dessas reuniões são relatadas.

Capítulos foram escritos ressaltando a importância dos auditórios e das bibliotecas nos programas arquitetônicos das escolas desse período. As janelas e sua relação com o espaço externo mereceram capítulo a parte, em que foram minuciosamente discutidas. Entretanto não consideravam, ainda, a escala da criança para definição final de suas dimensões.

A elaboração dos projetos dos novos edifícios escolares revelou a preocupação com as questões higienistas, que pautaram o urbanismo moderno, através da correta implantação dos edifícios em relação à insolação e à ventilação dos ambientes. Assim, a rígida simetria do edifício eclético das escolas da Primeira 
Republica rompe-se e cede espaço para o edifício que busca o sol. Edifícios com plantas em forma de "L", "Z", "U', "E" são projetados, de preferência, com os corredores que dão acesso aos ambientes de um só lado, para garantir a iluminação das salas de aula na fachada mais propícia à incidência de luz solar.

As salas, dispostas em corredores, unilateralmente, apesar de serem as melhores do ponto de vista da insolação, não foram as mais recomendadas, diante do enorme número de salas a ser construído; assim, recomendaram-se corredores com salas de aula dos dois lados, para tivessem, na cidade de São Paulo, iluminação NNE ou SSO. Todas essas recomendações foram feitas por Prestes Maia, em seu estudo publicado no livro "Novos Prédios para Grupo Escolar", baseadas na experiência de vários autores em diferentes países. Nesse estudo, Prestes Maia detalha as várias situações climáticas do estado de São Paulo e propõe, cientificamente, a adequação dos projetos a essas particularidades.

Com o intuito de gerar informações para a construção específica de edifícios escolares, Prestes Maia faz várias considerações a respeito da questão relativa à orientação dos edifícios; relata, por exemplo, um estudo que prioriza a busca pelo menor nível de ruído para o desenho das plantas, ou da melhor claridade e não, necessariamente, da melhor incidência solar. Em suas considerações, propõe a insolação para cada um dos ambientes a partir do uso pretendido, assim, até a fachada sul poderia ser a mais indicada para as aulas de culinária, por exemplo. Arremata, colocando que essas considerações fazem parte da maneira moderna de pensar o projeto, em detrimento da estética que dominava a simetria dos edifícios neoclássicos, então referência para a produção da arquitetura escolar. (in "Novos Edifícios para Grupo Escolar, págs. 42 a 60)
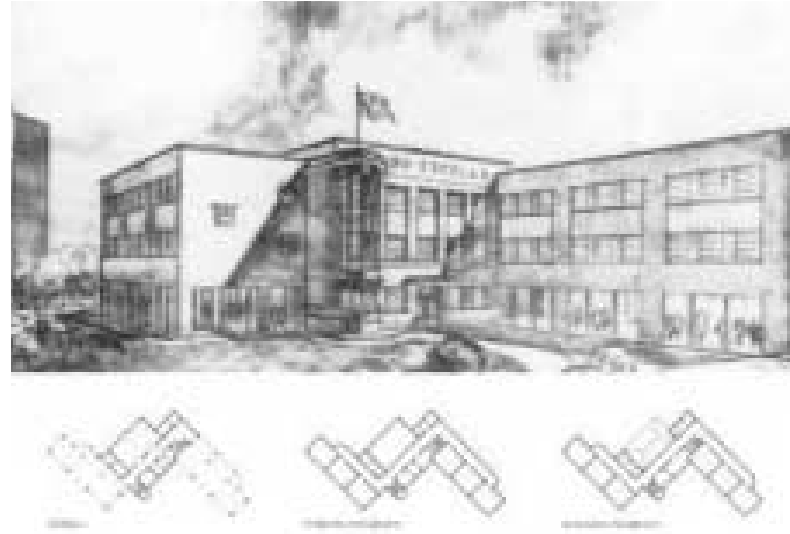

EEPG VISCONDE CONGONHAS DO CAMPO - JOSÉ MARIA DA SILVA NEVES
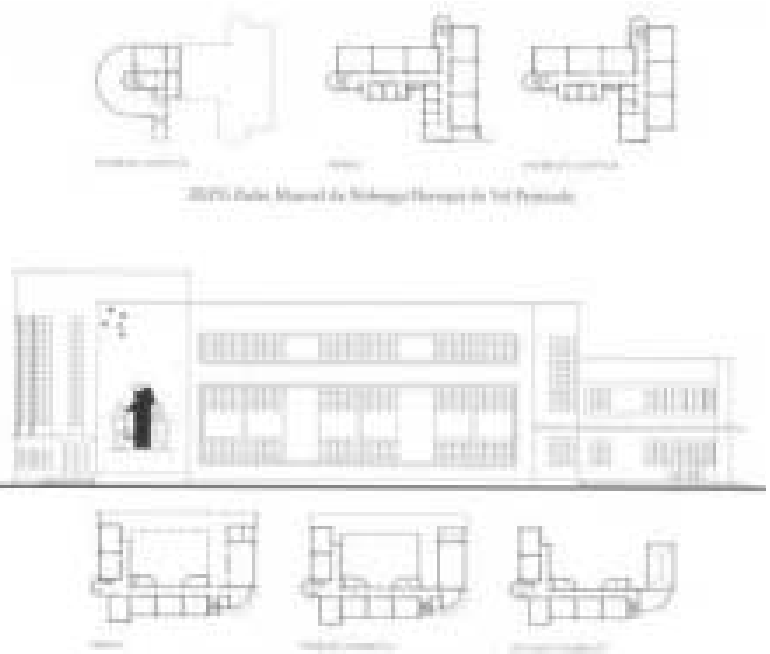

EEPG PROFa MARINA CINTRA - JOSÉ MARIA DA SILVA NEVES 
No livro "Novos Edifícios para Grupo Escolar", a arquitetura moderna é constantemente colocada como aquela que atende, em sua funcionalidade, à nova pedagogia.

A esse respeito, o arquiteto José Maria das Neves coloca que "as escolas de fachada" são substituídas por "fachadas de escolas", que resultam de uma nova maneira de compreender a função da arquitetura a serviço das questões educacionais; assim, critica o neocolonial como reprodução artificial de técnicas superadas, longe da verdade necessária que o edifício escolar deveria revelar, no tocante à sua construção.

"...fazer arquitetura não é somente construir fachadas. A arquitetura é função dos processos de construção da época. $O$ grande arquiteto de uma época é o seu estado social. Acima das obras, acima dos programas especiais, há o programa dos programas: a civilização de cada século, - a fé ou a incredulidade, a democracia ou a aristocracia, a severidade ou a desmoralização dos costumes. A verdade se impõe à arquitetura...

Fazer arquitetura moderna não significa copiar o último figurino de Moscou ou Paris. A arquitetura racional exige o emprego de materiais da região, atendendo às condições de clima, usos, costumes, etc. Obedecendo a esses princípios básicos criaremos um estilo para cada povo. Não deve haver temores quanto a monotonia da arquitetura.

A arquitetura nacional brasileira virá naturalmente, apresentando aspectos característico de cada estado." (in José Maria das Neves, págs. 63 e 64) 


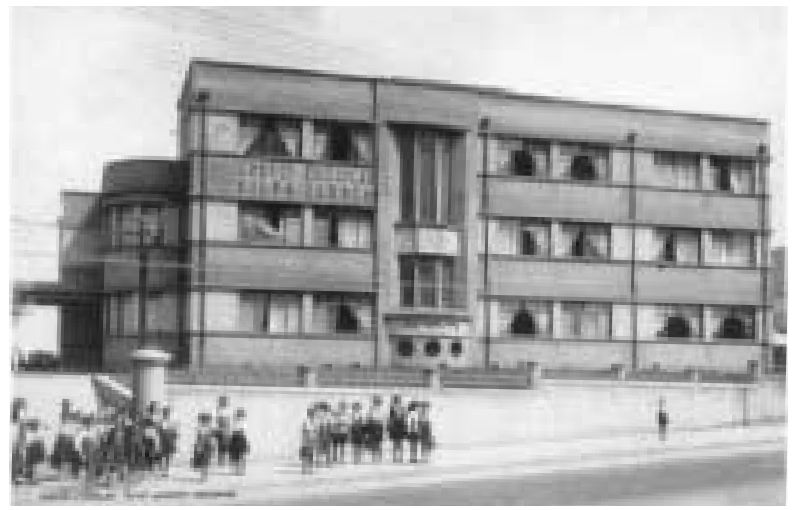

EEPG SILVA JARDIM - JOSÉ MARIA DA SILVA NEVES
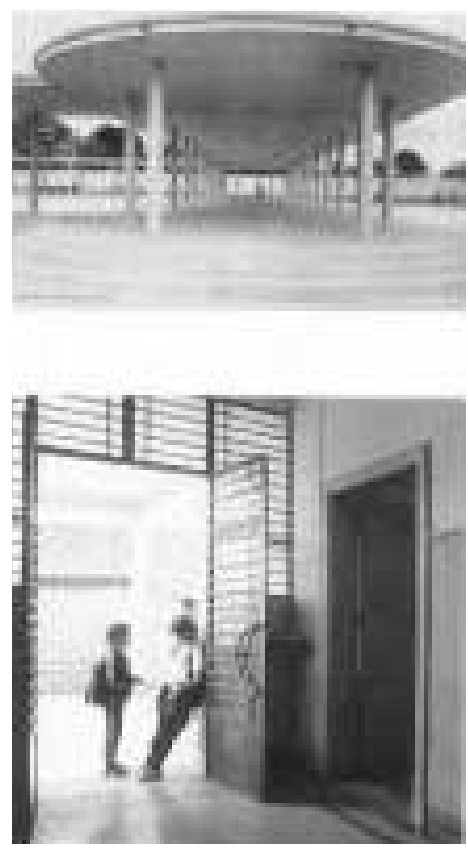

EEPG SILVA JARDIM
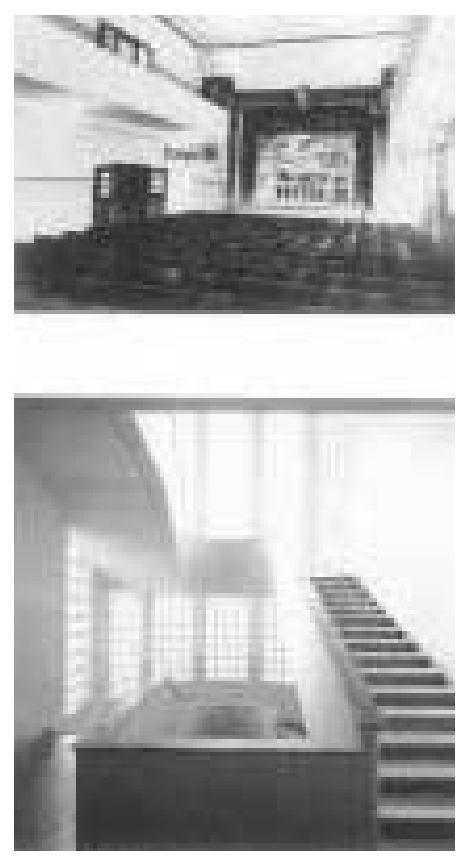

EEPG PROF ${ }^{\mathrm{a}}$ MARINA CINTRA

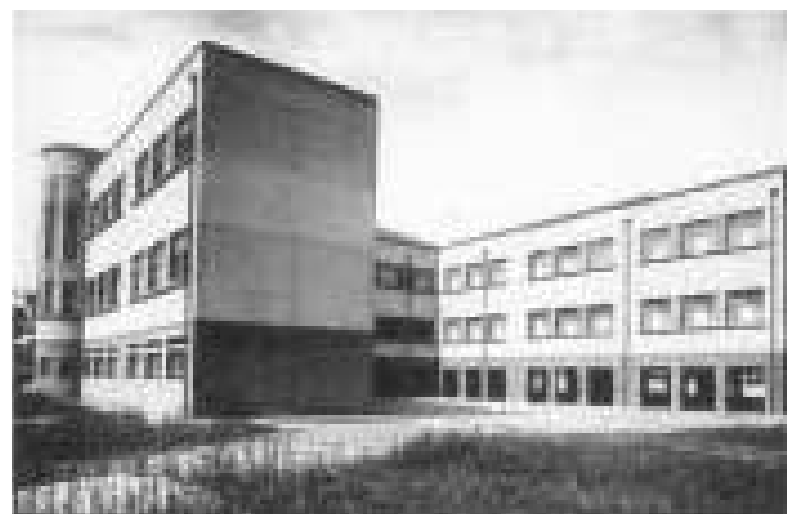

EEPG PROFa PRINCESA ISABEL - JOSÉ MARIA DA SILVA NEVES
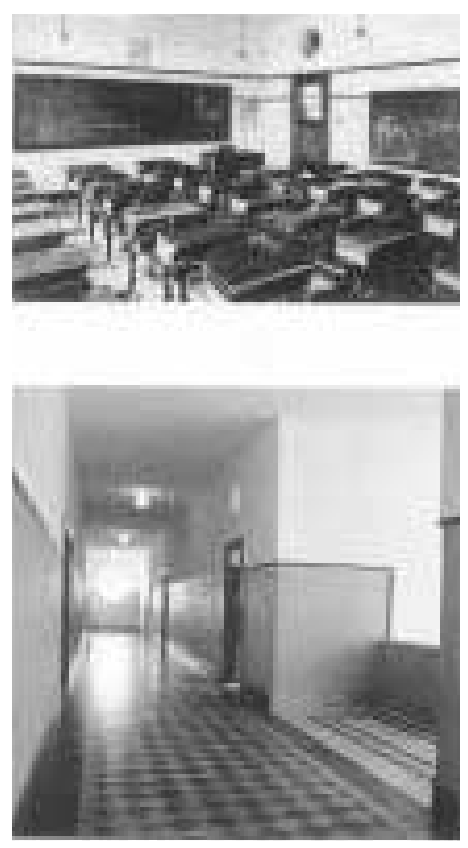

EEPG PRINCESA ISABEL 


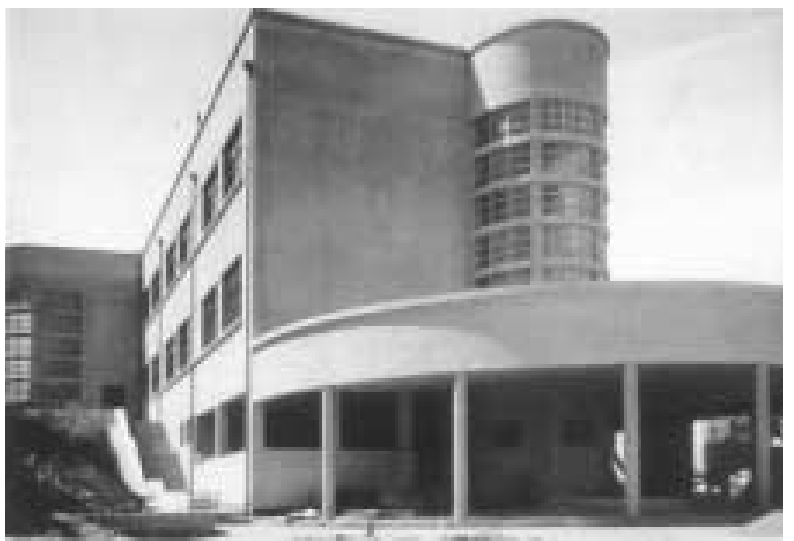

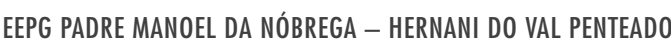

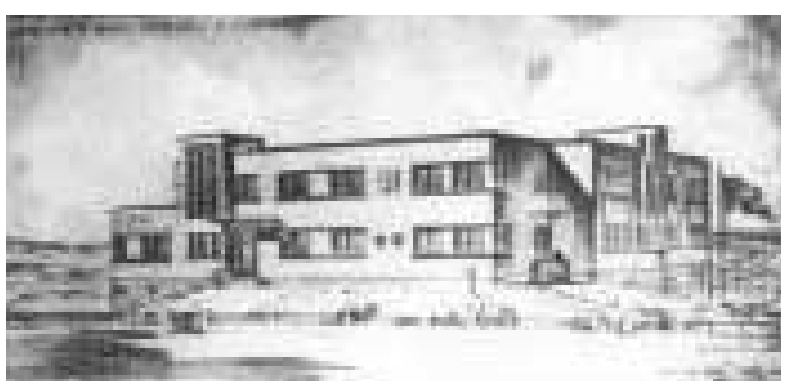

EEPG PROFa PRINCESA ISABEL - JOSÉ MARIA DA SILVA NEVES
Os volumes resultantes, a partir dos arranjos das plantas, são, dessa maneira, conseqüência da funcionalidade e eficiência pretendida no programa arquitetônico proposto. Assim, a planta, a partir das considerações funcionais, passa a ser a geratriz para o desenho da volumetria final.

A leitura dos volumes revela as funções dos ambientes: os maiores abrigam as salas de aula e mostram rasgos horizontais em toda a sua extensão, com molduras reforçando sua horizontalidade, uma vez que a, ainda incipiente, tecnologia do concreto armado não possibilitava o rasgo contínuo de todo o vão da sala de aula. Os volumes verticais das escadas, amplas e claras, por sua vez, quebram a horizontalidade do conjunto, funcionando como elementos plásticos de transição entre as diferentes funções e seus diferentes volumes.

Os volumes são marcados por aberturas que lembram escotilhas; nos terraços, seus guarda-corpos em alvenaria são arrematados por tubos metálicos, um conjunto de detalhes que remete à arquitetura naval, tão cara aos arquitetos que trabalhavam com a linguagem art déco. As entradas são marcadas por marquises que identificam a transição entre os espaços público e privado.

A volumetria final mostra um articulado conjunto de sólidos simples que, em alguns casos, ergue-se do chão através da colocação de pilotis, definindo o pátio coberto que, até então, era um volume separado do conjunto arquitetônico nas escolas da Primeira República.

Ensaia-se, assim, nos novos edifícios escolares construídos pela Comissão Permanente, o modernismo que precederia a composição dos edifícios escolares na década de 40 e 50 .

O livro "Novos Prédios para Grupos Escolares" registra na página 34 a explícita opção pela arquitetura moderna para as novas escolas: "modernismo 
sóbrio, discretamente sentimental, mais próximo do equilíbrio francês do que do arrojo desconcertante das composições mexicanas".

significativo resultado arquitetônico que descrevemos refere-se a um conjunto de apenas II escolas construídas na cidade de São Paulo, dentro de um conjunto em todo o Estado que somava mais de 400 edifícios, na maioria térreos e bastante singelos, com a finalidade de atender à enorme demanda por novas escolas.

Exemplos de referências à arquitetura neocolonial brasileira fizeram parte da linguagem adotada por algumas das escolas construídas no interior, em um claro compromisso de, no edifício escolar, refletir a busca de nossa identidade nacional.

Dois arquitetos merecem destaque na construção de escolas desse período, sendo que o primeiro - José Maria das Neves - projetou nove dos II edifícios mencionados. $O$ segundo é Ernani do Val Penteado, que projetou importantes obras públicas como funcionário do Departamento de Obras Públicas (DOP), entre as quais a mais significativa foi o Aeroporto de Congonhas, na cidade de São Paulo. José Maria das Neves, por sua vez, foi um incansável defensor da arquitetura moderna e da arquitetura de Le Corbusier, em particular.

Em 1934, a Associação Brasileira dos Educadores promoveu uma exposição de arquitetura escolar (num total de duas) em que o Prof. Sud Menucci argumentou sobre as vantagens da arquitetura moderna defendida por Le Corbusier e seus cinco pontos dogmáticos - terraço-jardim, janelas horizontais, fachada livre, uso de pilotis e planta livre. Ao analisarmos as escolas projetadas por José Maria das Neves, podemos concluir que seus projetos se comprometem com os pontos apregoados por Le Corbusier, ainda de maneira tímida, uma vez que nossa tecnologia construtiva era ainda incipiente para atender a todas as inovações propostas.

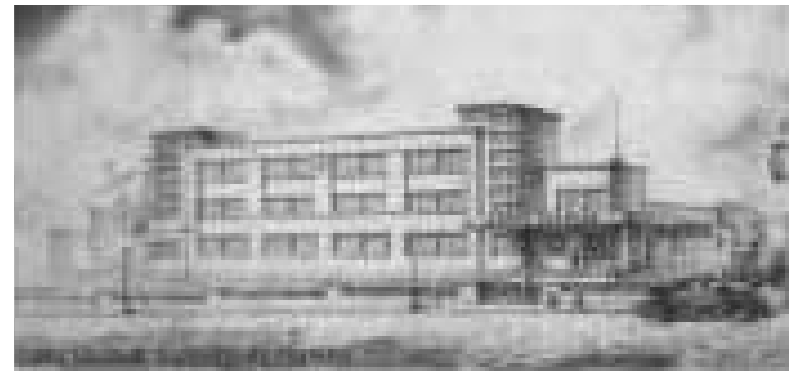

EEPG PROF GODOFREDO FURTADO - JOSÉ MARIA DA SILVA NEVES

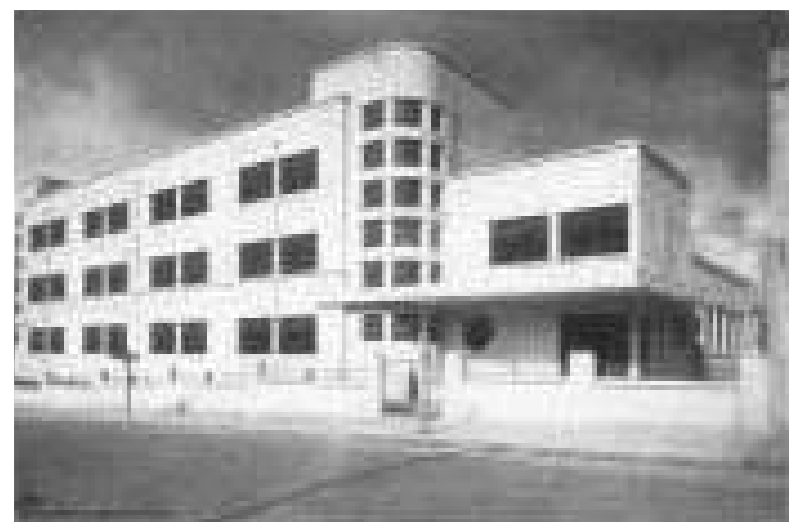

EEPG PROFa GODOFREDO FURTADO - JOSÉ MARIA DA SILVA NEVES 
1.4 MODERNIDADE NA EDUCAÇÃO DO MUNIĆIIIO DE SÃO PAULO: 0 DEPARTAMENTO DE CULTURA E RECREAÇÃO E OS PARQUES INFANTIS 
Até 1934, na esfera municipal, na cidade de São Paulo, nada se fez a favor da educação pública. Todas as questões ligadas à ela dependiam, até então, de uma ação da esfera estadual, até porque o município não tinha qualquer responsabilidade legal sobre essa questão. Alguns outros municípios do Estado, entretanto, mantinham escolas urbanas ou rurais com recursos próprios, em complementação à rede estadual (in Mascaro, 1960, pág. 59).

No município de São Paulo, os únicos recursos comprometidos com a educação popular, até então, serviram à manutenção da Biblioteca Municipal, do Teatro Municipal e do Parque Infantil do Parque Pedro Il. Algumas escolas de iniciativa privada também recebiam auxílio financeiro público da municipalidade (in Mascaro, 1960, pág. 59).

Essa situação se modifica a partir de 1935, reflexo do determinado pela Constituição Federal de 1934, quando a cidade de São Paulo, sob a gestão do Prefeito Fábio Prado, através do Departamento de Cultura e Recreação, passa a ser núcleo irradiador de cultura para todo o Estado.

O governador do Estado de São Paulo era Armando de Salles Oliveira que, em 1934, fundou a Universidade de São Paulo, entre as várias medidas para colocar o Estado de São Paulo no papel que deveria ocupar, em função de seu desenvolvimento econômico, dentro do projeto de construção de um país moderno e industrializado.

O prefeito Fábio Prado ao assumir o cargo contou com a colaboração de um importante grupo de intelectuais, que passariam a apoiar e a colaborar com a modernização da administração municipal paulista. $\bigcirc$ modernista Mário Andrade, um destes intelectuais assumiu, em 1935, a diretoria do Departamento de Cultura e Recreação, que abrangia o serviço de Parques Infantis, cuja finalidade era de dar

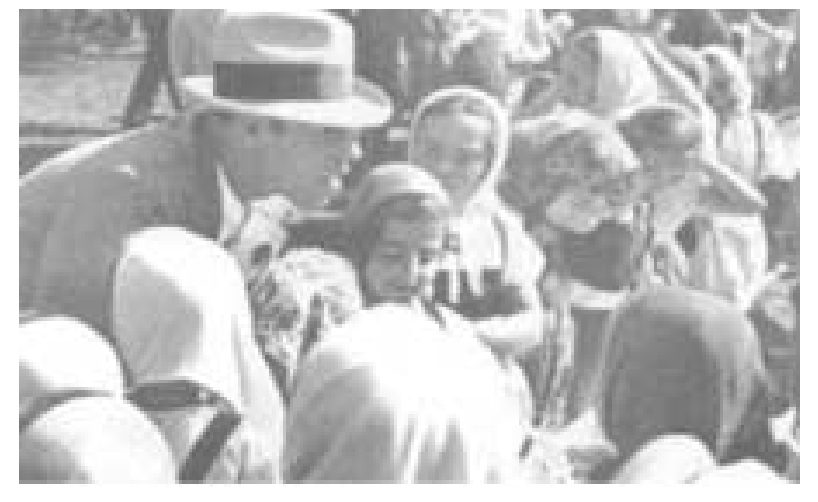

MÁRIO DE ANDRADE EM VISITA AO PARQUE ESCOLAR 


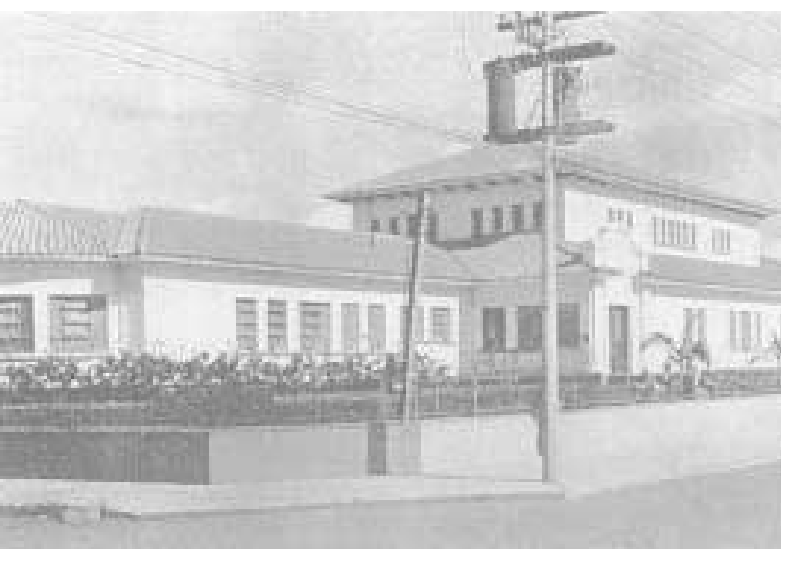

PARQUE INFANTIL DA BARRA FUNDA (1940)

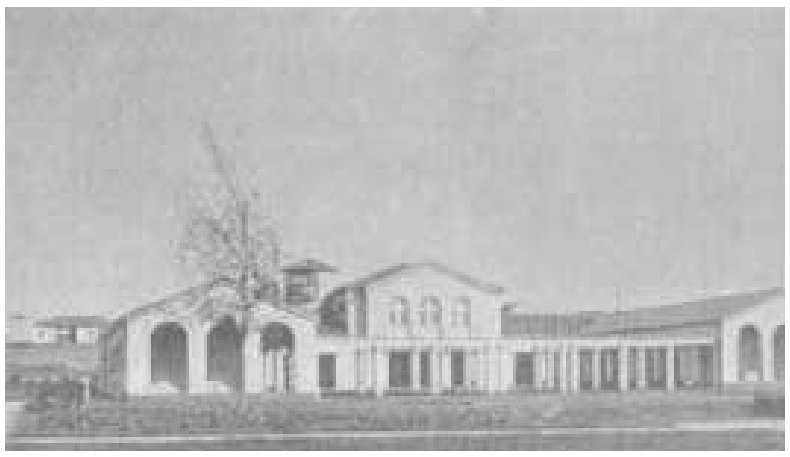

PARQUE INFANTIL DA VILA ROMANA (1940) assistência a menores e educação extra-escolar, complementando a rede de escolas estaduais.

É através desse serviço, por iniciativa de Mário de Andrade, que assistiu-se a construção de parques infantis em várias regiões da nossa cidade, inaugurando um original sistema de educação extra-escolar que serviria de referência a outras cidades do continente europeu e americano, que aqui vieram buscar inspiração para a implantação de instituições para a educação infantil, os mesmos europeus e americanos que, em um primeiro momento, serviram de referência para a construção dos primeiros parques infantis paulistanos.

Importante salientar que, sob a direção de Mário de Andrade, os primeiros parques infantis não foram reduzidos a dar continuidade à idéia do lazer organizado das cidades industriais com a função de um papel moralizador, higienista e controlador do trabalhador urbano, particularmente das crianças, filhos desses trabalhadores. Mário de Andrade ampliou em muito as possibilidades deste equipamento urbano e vê nos parques infantis a possibilidade de investir na educação do trabalhador desde a sua mais tenra idade, incuntindo-lhe os valores de nossa nacionalidade, na construção de um espírito de brasilidade, tão caro a todos os modernistas da Semana de 22, ou seja, o papel moralizador e organizativo, presente na gênese dos parques infantis, ganham contornos revolucionários em nossa cidade.

No parque infantil, a primeira instituição de iniciativa municipal com a finalidade de educar os filhos dos trabalhadores urbanos, em sua maioria marginais às instituições de ensino privadas e mesmo da incipiente rede pública estadual de escolas, as crianças puderam encontrar um meio de se apropriar da cultura urbana em um espaço físico desenhado para essa finalidade. Naquele momento, o 
Departamento de Cultura e Recreação previa a articulação dos Parques Infantis aos melhoramentos urbanos previstos para a cidade de São Paulo, conforme afirma Niemeyer em seu livro "Parques Infantis de São Paulo - Lazer como expressão de cidadania", pág. 104.

Os parques infantis atenderam, no âmbito municipal, ao que fora formulado na Constituição Federal de 1934 em que se estipulou que caberia aos Municípios entrosar suas iniciativas educativas às iniciativas do Estado voltadas à complementação do sistema educacional em construção. Assim, as autoridades municipais, através da Lei Orgânica, deliberaram não estabelecer qualquer sistema paralelo, ou rede de escolas concorrente com o sistema estadual. Conforme nos relata Mascaro em seu livro "O Município de São Paulo e o Ensino Primário", pág. 65.

Assim, por ser a única iniciativa municipal voltada à educação, o Departamento de Cultura e Recreação contou com vultosos recursos para seus projetos que correspondiam a 10\% do recolhimento dos impostos do Município, especificamente para a construção dos primeiros parques infantis.

uso desses recursos pelo Departamento de Cultura levou a grandes discussões na Câmara Municipal, chegando a ser proposta a construção de uma rede de mil escolas municipais, colocando em questão à iniciativa municipal de, através dos parques infantis, complementar à instrução já oferecida pela rede estadual.

Discutido o tema, entretanto, a Câmara Municipal votou manter os recursos para o Departamento de Cultura e Recreação. Mais tarde, a colaboração entre o Estado e o Município no âmbito dos Convênios Escolares delineou o papel de cada uma das esferas, na construção de uma rede de edifícios dentro de nosso Município.
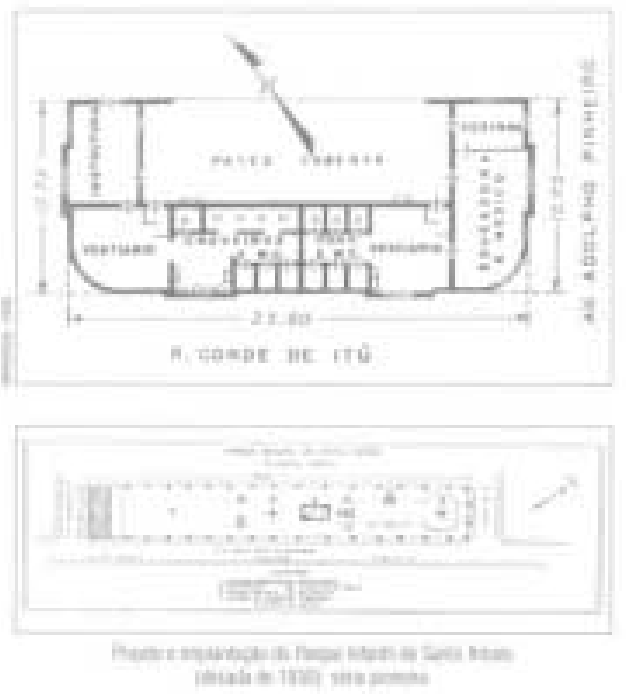

PROJETO E IMPLANTAÇ̃̃ DO PARQUE INFANTIL DE SANTO AMARO (DÉCADA DE 1930): SÉRIE PIONEIRA 


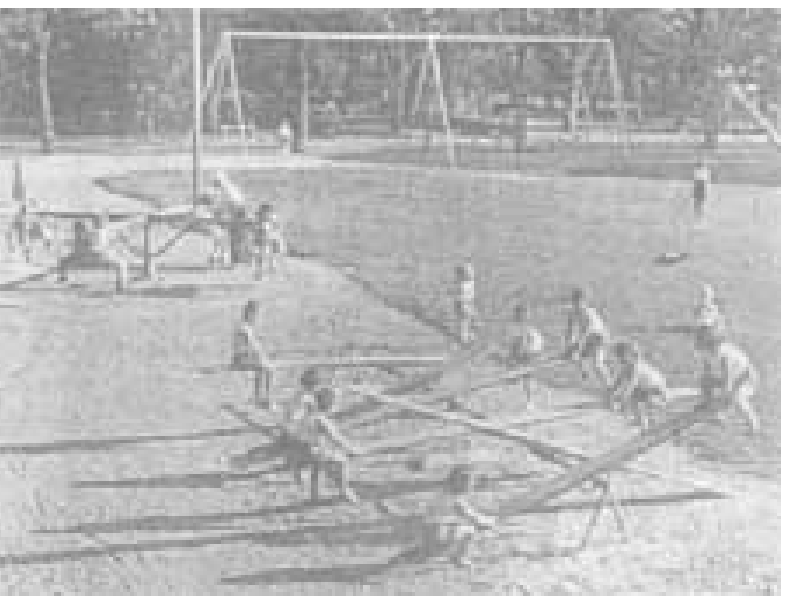

PARQUE INFANTIL D. PEDRO II INSTALADO NO INTERIOR DO PARQUE DE MESMO NOME (DÉCADA DE 1940)

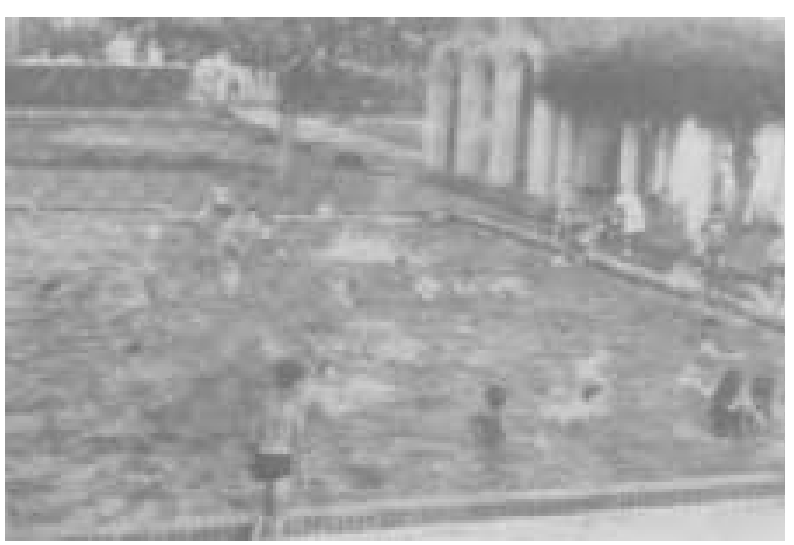

PARQUE INFANTIL DA VILA ROMANA (1940)
Em função de uma política Federal modernizadora e industrial, implementada por Getúlio Vargas, assistiremos ao surgimento de grandes parques industriais pelo país. A cidade de São Paulo, em particular, assume o papel de protagonista desta crescente industrialização e urbanização, processo que se reflete no crescente movimento migratório do campo para as cidades, inchando-as com uma densidade populacional que a sua precária infra-estrutura não conseguirá atender com dignidade.

Uma sociedade rigidamente hierarquizada, com base em uma política agroexportadora, é paulatinamente substituída por uma sociedade industrial urbana. Assim, novos hábitos e novos personagens passam a fazer parte do cenário urbano. São operários, funcionários públicos, profissionais liberais, estudantes de todas as faixas etárias, professores, comerciantes, bancários, que passam a disputar as oportunidades de trabalho dentro das novas possibilidades de mobilidade e inclusão social, criadas por um estado republicano e industrial. A escola, assim, passa a ser o trampolim para a ascensão do imigrante e do trabalhador urbano recém-chegado em nossas cidades.

Os parques infantis, na escala Municipal, passam a atender a esse público infantil que, ao ter um apoio extra-escolar, se educa a conviver nas grandes cidades, nele são incutidos novos hábitos de higiene, a prática de jogos esportivos organizados e a iniciação às questões de saúde pública. $\bigcirc$ lazer e o tempo livre eram assim meticulosamente controlados, o que convencia até os mais retrógrados políticos sobre a eficácia desse empreendimento. É importante salientar, que o número de escolas públicas ainda era ínfimo, e o atendimento tornava-se cada vez mais precário, em detrimento do enorme crescimento da cidade paulistana que, nessa década, já alcançava a casa de um milhão de habitantes. 
Na modernização da máquina administrativa, promovida pelo prefeito Fábio Prado, não só o poder executivo passou por grandes mudanças modernizadoras, mas também a Câmara Municipal se modernizava, ao criar comissões específicas para a discussão de questões culturais e educativas referentes à cidade paulistana.

Todo o avanço assim realizado deveu-se, conforme nos relata o educador Carlos Corrêa Mascaro, à atuação de um grupo reduzido mas seleto de colaboradores, dos quais se cercara o prefeito Fábio Prado, especificamente, para a realização de estudos relacionados à criação do Departamento de Cultura, que contava com notáveis colaboradores, entre eles o educador Fernando de Azevedo, mentor dos parques infantis urbanos da cidade paulistana.

Os parques infantis, além de criarem uma referência para o desenvolvimento de projetos educacionais, consideradas as questões do uso dos espaços livres urbanos, possibilitaram o início da discussão sobre a questão educacional de iniciativa municipal.

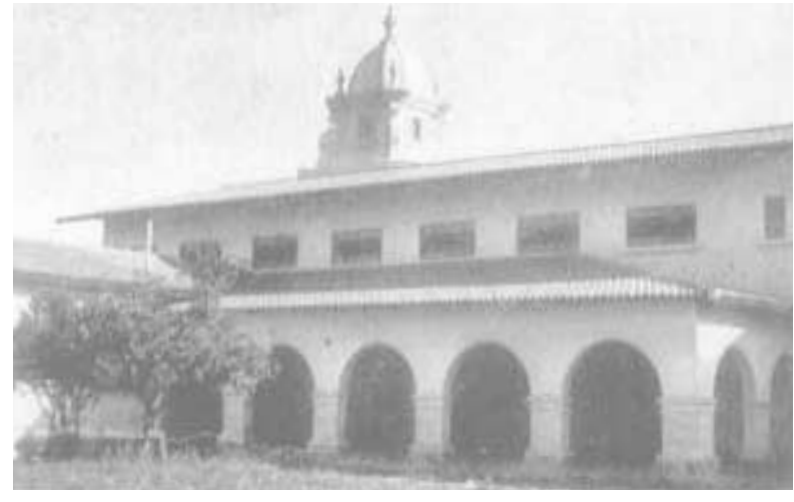

PARQUE INFANTIL PRESIDENTE DUTRA (1949) 
1.5 OS CONVÊNIOS ESCOLARES: 0 DIÁLOGO CONSTRUÍDO ENTRE 0 ESTADO E 0 MUNICÍPIO PARA A AMPLIACÃA DA REDE PÚBLICA DE ESCOLAS. O SUCESSO DO $2^{\circ}$ CONVÊNIO 
O convênio entre a União, Estados e Municípios, com a finalidade de implementar um sistema de ensino primário no país, foi conseqüência da promulgação do Decreto-Lei Federal n 4.598, de 1942, no qual foi instituído o Fundo Nacional de Ensino Primário.

Através desse fundo estabeleceram-se cotas de arrecadação para cada uma das esferas de poder e definiram-se as bases para a efetivação dos sistemas educacionais propostos. Como já foi colocado, a Constituição de 1934 estabeleceu uma cota da arrecadação para aplicação nos sistemas de ensino equivalente ao recolhimento de $20 \%$ dos impostos arrecadados pelos Estados e de $10 \%$ dos impostos arrecadados pelos Municípios com a finalidade do desenvolvimento e manutenção dos sistemas educativos.

Os convênios criados pelas três esferas foram além da definição de cotas de arrecadação e contribuição; estabeleceram uma fórmula de colaboração entre os poderes e o modo como deveriam ser aplicados os recursos recolhidos no desenvolvimento de um sistema educativo a nível nacional, de acordo com Carlos Correa Mascaro em sua obra "O município de São Paulo e o Ensino Primário", págs. 71 e 72.

Os convênios, entretanto, não apresentaram substancial resultado em escala nacional, sobretudo nos acordos estabelecidos entre a União e os Estados.

A cidade de São Paulo, assim como outros municípios do estado de São Paulo, recorrem aos convênios firmados entre o Estado e o Município para o atendimento à crescente demanda por educação pública e, mais especificamente, para a construção de edifícios escolares, uma vez que o município de São Paulo, até a década de 60, ainda não contava com uma estrutura própria para a sua construção. 
Nos convênios firmados entre o Estado e o Município de São Paulo, no total de três, pudemos ver variações nas atribuições de cada uma das partes. Ao Estado, independente das cláusulas de cada convênio, sempre coube a responsabilidade pela formação do quadro de professores, do quadro administrativo e da manutenção das escolas, e ao Município, a construção dos edifícios escolares. As discussões sobre as competências e responsabilidades das partes, mais tarde, suscitaram a possibilidade da municipalização do ensino na cidade paulistana.

A arquitetura escolar, a serviço de uma específica questão municipal e o edifício escolar com suas particularidades, através da definição do programa arquitetônico, traduz um modo de educar, uma determinada linha pedagógica; assim sendo, em pouco tempo, as questões específicas de nossa cidade exigiram uma particularização do programa a ser atendido; não caberia mais o mesmo edifício, com o mesmo programa arquitetônico, que se repetia por todo o Estado, para a cidade de São Paulo, sobretudo na década de 40, quando já figurávamos como uma grande metrópole industrial.

Foram três os convênios escolares firmados entre o Estado e o Município de São Paulo. O primeiro reduziu-se à construção de somente três novas unidades, sem importância relevante quanto ao resultado arquitetônico; o segundo, objeto deste estudo, notabilizou-se pela produção de 52 edifícios no espaço de cinco anos, marcando a arquitetura pública de nossa cidade com a afirmação da arquitetura moderna em nossa paisagem, sobretudo nos bairros que atendeu, e o último convênio, derradeiro, construiu pouco mais de 15 unidades.

Nos estudos referentes aos convênios escolares, reduz-se os três acordos ao $2^{\circ}$ Convênio, dado o alcance que obteve em relação aos demais; entretanto, é 
importante fixarmos suas diferenças, até para compreendermos as causas que levaram ao feliz resultado isolado desse $2^{\circ}$ Convênio.

\subsection{1 $01^{\circ}$ CONVÊNIO ESCOLAR (1943 - 1948)}

O $1^{\circ}$ Convênio foi celebrado em 14 de setembro de 1943, quando era interventor estadual Fernando da Costa e nomeado prefeito, desde 1938, o urbanista Francisco Prestes Maia. Nesse ano, a cidade de São Paulo já era considerada o maior aglomerado humano do país, o maior parque industrial da América Latina e a cidade de maior índice de crescimento urbano em todo o mundo. Esses números deveramse, sobretudo, ao cenário mundial que, em função da $2^{\text {a }}$ Grande Guerra arrasou a Europa e proporcionou o crescimento industrial de países americanos. Há que se considerar, para complementar o cenário em que se instalara o $1^{\circ}$ Convênio, que ainda estávamos sob o regime do Estado Novo de Getúlio Vargas.

O convênio escolar fez-se necessário devido ao grande número de crianças sem escola na cidade paulistana, cuja população já encostava na casa de I milhão de habitantes, e a colaboração entre Estado e Município foi estratégica, a fim de reverter a situação alarmante que esse apresentava.

Educar as crianças passou também a ser estratégico para a nova burguesia industrial que se firmava, uma vez que a indústria Ihe cobraria mão-de-obra qualificada, a fim de garantir o constante desenvolvimento de seu parque industrial.

Nessa soma de esforços, caberia ao município a construção das escolas e ao estado, a formação dos professores e a abertura das salas de aula a serem 
construídas. Para tanto, o Município estaria obrigado a contribuir com um valor fixado percentualmente sobre sua receita (advindas do recolhimento de impostos): nos cinco anos desse Convênio (1943 a 1948), o município reservaria, respectivamente ano a ano, as porcentagens de 10\%, $11 \%, 12 \%, 13 \%$ e $15 \%$.

A cota anual reservada, de acordo com o estabelecido pelos termos do convênio, deveria ser dividida em 3 partes: a primeira de 68\% seria destinada à construção, compra, adaptação, restauração e conservação de terrenos e prédios escolares para o ensino primário ou para instituições auxiliares; a segunda de 10\% deveria ser reservada para o serviço de Caixa Escolar e para a instalação das instituições auxiliares da escola primária, e a terceira, de 22\%, para a construção, ampliação e manutenção das bibliotecas, parques infantis municipais e auxilio municipal às escolas primárias ou instituições auxiliares. Caso a verba reservada para determinado ano não fosse totalmente utilizada, deveria ser reservada para o próximo ano, a fim de ser investida na construção da rede primária de ensino.

Foi formada uma Comissão de cinco membros, composta por profissionais da Secretaria Estadual de Educação e Saúde e da Prefeitura Municipal, com a finalidade de informar e dar suporte técnico às ações do convênio.

O estado, por sua vez, comprometia-se a continuar investindo na compra e construção de edifícios escolares e a criar "o quadro de pessoal docente e administrativo necessário ao bom desempenho dos serviços do ensino primário e das instituições auxiliares" e "a prestar toda a assistência técnica solicitada pelo município, para a mais perfeita organização dos serviços do ensino primário".

Apesar da clareza com que se redigiram os termos do Convênio, os resultados foram pífios, perante as necessidades da população em idade escolar que 
deveria se atendida. Foram vários os motivos que contribuíram para o fracasso dos objetivos. Entre eles, merece destaque, conforme nos relata Carlos Corrêa Mascaro, na pág. 76 de seu livro "O município de São Paulo e o Ensino Primário":

"O compasso de espera inicial decorreu, segundo afirmam, do estilo de ação do então prefeito - urbanista de prestígio firmado e autoridade acatada pela orientação que havia adotado e vinha imprimindo... Centralizador e autoritário, o prefeito começou por não promover a instalação da Comissão prevista na cláusula 12 do Convênio, preferindo traçar pessoalmente os planos e fazer elaborar, por engenheiros de sua confiança pessoal e fiscalizar, pelo Departamento Municipal de Obras, sob suas vistas diretas, os projetos que seriam financiados pela Prefeitura, entregando as construções, sob regime de administração, a firmas idôneas."

As primeiras escolas começaram a ser construídas somente em 1944 e visaram a atender os bairros de maior densidade populacional. Foram projetados edifícios de grande porte, de maneira a abrigar grande parte das crianças de um mesmo bairro.

"Construções de grande porte, sólidas e bem planejadas, capazes de impressionar pela majestade de suas linhas e capacidade de abrigar numerosa clientela. Junto ao estabelecimento deveriam ser construídas dependências para a instalação de serviços de assistência alimentar escolar, gabinetes médicos e dentários". (Mascaro, 1960, pág. 77)

O saldo da administração de Prestes Maia foi somente de três novas escolas, algumas bibliotecas e parques infantis. Em 1945, com o fim do governo de Getúlio 
Vargas, novo prefeito é imposto - o jurista Abrahão Ribeiro - e a partir dele, apesar de o Convênio Escolar manter-se, é dada prioridade à construção dos parques infantis, equipamento que sempre caracterizou os investimentos dos governos municipais paulistas na área da educação, desde o mandato do Prefeito Fábio Prado.

A morosidade no atendimento e o pouco volume de obras resultaram, entretanto, em uma generosa reserva de dinheiro a ser aplicada no $2^{\circ}$ Convênio Escolar. Importante salientar que neste período como no período do governo de Prestes Maia, a Comissão Executiva praticamente não existiu, ficando a cargo do Gabinete do Prefeito as decisões a respeito da aplicação e das prioridades a serem dadas para as obras do Convênio Escolar.

Em 1946, é promulgada nova Constituição e nela fica determinada a nova cota a ser aplicada na educação: 20\% e não mais os 15\% dos recursos já reservados pelo município paulista.

O final do $1^{\circ}$ Convênio é marcado, na administração estadual do governador Adhemar de Barros, pela constante troca de prefeitos, por um enorme saldo de dinheiro no caixa da Secretaria de Educação e Cultura e pela prioridade no atendimento à criança resumido aos parques infantis ( 8 construídos no total).

Somente em 1948, é instituída a Comissão Executiva do Convênio Escolar, prevista desde 1943. Sua principal tarefa passou a ser o estudo para a base de sua renovação, uma vez que se compreendeu que, para a parceria estado e município dar certo, a comissão seria estratégica para resolver com independência a enorme demanda de salas de aula.

Em 1950, já sob a gestão do $2^{\circ}$ Convênio Escolar, a Comissão Executiva divide-se em duas subcomissões: uma de planejamento e outra de construções; assim, 
independentes do gabinete do Prefeito conseguem trabalhar e atender à construção de edifícios escolares com mais eficiência ao poder colocar em prática suas metas.

\subsection{2 $02^{\circ}$ CONVÊNIO ESCOLAR (1949-1953)}

O $2^{\circ}$ Convênio escolar foi assinado em 28 de dezembro de 1949. Para presidente da Comissão Executiva foi nomeado o engenheiro José Amadei que exercia, até então, na prefeitura de São Paulo, o cargo de diretor do Departamento Municipal de Obras; para diretor da Subcomissão de Planejamento foi nomeado o arquiteto Hélio de Queiroz Duarte, recém-chegado da Bahia, onde trabalhara diretamente com o educador Anísio Teixeira e, para a Subcomissão de Obras o engenheiro Ernesto de Faria Alves.

Conforme Decreto n 1.|45, de 30 de maio de 1950, eram atribuições das subcomissões:

Artigo $2^{\circ}$ - Compete à Subcomissão de Planejamento:

a) a pesquisa e coleta dos elementos indispensáveis à boa localização e dimensionamento dos imóveis, cuja aquisição seja de interesse para o Convênio Escolar;

b) o exame dos terrenos convenientes à construção de novos prédios, bem como tomar as providências necessárias ao seu recebimento em doação, por aquisição amigável ou expropriação judicial;

c) a elaboração de projetos de novos prédios e de reformas dos já existentes, desde que sejam de propriedade do Estado ou do Município 
e de adaptação dos que, para os fins previstos no Convênio Escolar, forem adquiridos.

Artigo $3^{\circ}$ - Compete à Subcomissão de Construções:

a) a elaboração de orçamentos e de editais de concorrência para a execução das obras;

b) a direção, quando por administração direta, e a fiscalização, quando por empreitada ou por administração contratada, da execução das obras;

c) a recepção, guarda e distribuição de todo o material permanente destinado às escolas e instituições auxiliares.

A Comissão Executiva do Convênio Escolar não se subordinava diretamente a nenhuma Secretaria, mas diretamente ao Prefeito, conforme estipulado pelo decreto do convênio.

As aplicações anuais deveriam obedecer à seguinte divisão de verbas, de acordo com seu Decreto de regulamentação:

"72\% para construção, aquisição, adaptação restauração e conservação de imóveis destinados ao ensino de pré-primário, primário, secundário, especializado e instituições auxiliares de ensino primário, dentro das divisas do município, inclusive na aquisição de mobiliário e instalações para os novos edifícios e nas despesas da Comissão Executiva; 23\% para manutenção de instituiçães auxiliares de ensino primário e auxílio às escolas primárias e instituições auxiliares destas; $5 \%$ para a Caixa Escolar. Consideravam-se instituições auxiliares de ensino primário: as bibliotecas e parques infantis, os serviços de assistência médica, terapêutica e dentária, de alimentação supletiva, cinema educativo, parques recreativos, de desportos ou de 
educação física, colônias de férias, desde que destinadas aos escolares de estabelecimentos de ensino primário oficial e particular não remunerado, registrado no departamento de educação do Estado." (Mascaro, 1960, pág.83)

O $2^{\circ}$ Convênio Escolar apresentou à sociedade um completo programa de atendimento a todas as necessidades das crianças pobres da cidade, dando-lhes condições plenas de se desenvolver como cidadãos; entretanto, a população infantil crescia muito além do previsto inicialmente e, assim, o convênio não conseguiu alcançar seus objetivos de atender a todas as crianças que, anualmente, procuravam por vagas na rede pública.

$\bigcirc 2^{\circ}$ Convênio caracterizou-se pela construção de edifícios de menor porte com, na maioria, 12 salas de aula. Este critério adotado substitui o anterior de construir grandes edifícios, reflexo da carência que se generalizou por toda a cidade na falta de salas de aula. Assim, optou-se por formar, a partir dos edifícios escolares, pequenas comunidades de bairro, dentro de um raio de $1.500 \mathrm{~m}$ de abrangência, de modo a se distribuírem por todo o município paulistano.

Nos primeiros três meses de trabalho a Subcomissão de Planejamento procurou fazer um levantamento detalhado da demanda das carências por salas de aula por toda a cidade, pois mesmo os escassos levantamentos estatísticos existentes na época mostravam a calamitosa realidade existente. Por mais ágeis que fossem as respostas dessa subcomissão o crescimento da cidade e de sua população extrapolavam qualquer planejamento que se fizesse.

Os trabalhos da Comissão Executiva do $2^{\circ}$ Convênio Escolar demonstraram, em cinco anos de atividades, um surpreendente resultado: 
"Em cinco anos, a Comissão se mostrara capaz de construir quase novecentas salas de aula, cerca de 180 por ano. Ela também já havia, na mesma ocasião, localizado 4 I terrenos, colocando-os em vias de desapropriação, para neles serem levantados edifícios para grupos escolares de diferentes tamanhos, além do relacionamento de 19 outros prontos para receber as construções projetadas prela Comissão do Convênio, duas na fase de pronto início das obras, 4 em concorrência pública e as restantes com os projetos em estudo. Havia ainda 34 Projetos de Lei de desapropriação preparados. Acrescentem-se a esses, 12 outros, cujas obras iriam ser postas em concorrência pública". (in Mascaro, 1960, pág. 91)

Esse resultado revela um processo que aplicou como princípio a produção em série de projetos, de acordo com o preconizado pela moderna arquitetura brasileira, nessa época reconhecida mundialmente, por revelar uma linguagem arquitetônica singular, relativa à produção mundial.

O crítico de arte, Sr. Quirino da Silva, sobre a exposição que aconteceu no MASP, em que se mostraram, através de maquetes e projetos, escolas projetadas pela Comissão Executiva, escreveu:

"O sentido dessa obra de grande alcance social parece ter-se orientado dentro do mais sadio critério, porque os membros da referida Comissão não se restringiram somente a construir escolas; antes procuraram, acima de tudo, edificar obras que refletissem um espírito moderno, compatível com as normas da moderna pedagogia. Os edificios dos grupos escolares até agora construídos, bem atestam o caráter de modernidade das modernas casas de ensino. Compreenderam, pois, que era indispensável educar as crianças num ambiente que refletisse a conquista da arquitetura contemporânea, para que estas bem cedo se familiarizassem com as formas que surgiram como produto natural de nossa cultura e civilização. A moderna 
arquitetura, realizada sob a orientação da Comissão de Convênio é um fato que orgulha São Paulo, não só por partir dos poderes públicos, mas também, por ser obra de grande extensão empreendida somente em países de organização social bastante evoluída. Para termos uma idéia dos trabalhos da Comissão do Convênio, basta visitar a mostra da arquitetura Escolar recentemente inaugurada na grande sala de exposições periódicas do Museu de Arte. Ali está, em suas linhas sóbrias e modernas, o ambiente em que será educada a futura geração desta cidade. Os projetos são dignos do bom nome que a arquitetura brasileira granjeou no estrangeiro, e o Museu de Arte, ao pôr em relevo o programa do Convênio, transmite um apelo ao governo para prosseguir nessa orientação de apoio aos valores da arquitetura contemporânea. Esperamos que essa orientação sadia atinja também outros órgãos da administração pública". (in Mascaro, 1960, págs. 100 e 101)

Mesmo alcançando reconhecimento de vários setores da sociedade, a Comissão Executiva do $2^{\circ}$ Convênio Escolar, por ocasião das eleições para a Câmara dos Vereadores de 1951, passou a receber críticas de vários vereadores que, em sua maioria, não sabiam dos reais propósitos e obrigações do Convênio. As críticas fundamentavam-se a partir dos seguintes problemas enfrentados para a viabilização da construção dos edifícios escolares:

- o tempo para a efetivação do processo de desapropriação era longo, por todas as suas implicações legais e, mesmo com as devidas explicações do presidente da Comissão Executiva, os vereadores colocavam responsabilidade desta morosidade na ineficiência dos profissionais que participavam da Comissão, de modo a levá-la ao descrédito popular;

- o número de crianças a serem atendidas extrapolava aquele projetado pela 
Comissão; assim, as escolas, mesmo projetadas e construídas em tempo recorde, não atingiam a população necessária;

- as sobras de dinheiro do orçamento anual destinado à Comissão do Convênio revelavam, no modo de entender dos candidatos a vereador, ineficiência da equipe na produção das escolas, o que era rebatido pela Comissão, tentando esclarecer que o processo envolvia não somente o tempo de projeto e sua construção, mas também o tempo das desapropriações e licitações para as obras.

fato é que o Convênio contava com uma verba vultosa para a realização de suas metas, verba essa desejada por outros órgãos da prefeitura que, muitas vezes, dela tentaram se apropriar para aplicação em obras de melhorias urbanas que não necessariamente tinham a ver com as escolas. A aproximação do IV Centenário de aniversário da cidade também fez com que parte dessa verba fosse desviada para a construção do Parque do Ibirapuera.

ano de 1951 foi marcado pela eleição direta para prefeito que, até então, era escolhido diretamente pelo Governador do Estado. Venceu a eleição o candidato Jânio Quadros, que passou a interferir diretamente nas ações da Comissão Executiva. O arquiteto Hélio Duarte chegou a receber "bilhetinhos" diretamente do Prefeito solicitando alterações no planejamento traçado pela equipe.

Os membros da Comissão do Convênio gastaram parte de seu restrito tempo de trabalho para responder ofícios de vereadores e políticos, dando explicações que, muitas vezes, estavam publicadas nos objetivos do Convênio, em conformidade com seus Decretos de regulamentação. Em meio a esse desgaste e tendo chegado o ano de 1954, o arquiteto Hélio Duarte demitiu-se do cargo de diretor da Subcomissão de Planejamento. 
detalhado estudo dos 52 edifícios escolares projetados e seu modo de produção é tema do $3^{\circ}$ capítulo desta dissertação.

\subsection{3 $03^{\circ}$ CONVÊNIO ESCOLAR (1954-1959)}

O $3^{\circ}$ Convênio Escolar foi promulgado através da Lei Estadual n².816, de 27 de novembro de 1954, e difere dos demais por carregar consigo, desde o ano de 1951, quando foram iniciadas as negociações para a renovação do $2^{\circ}$ Convênio, a discussão sobre a municipalização do ensino em nossa cidade. Os recursos que se avolumavam ano a ano, em decorrência do crescente aumento do recolhimento de impostos e pelo fato da Comissão Executiva, pelos motivos já enumerados, não gastar o dinheiro reservado, continuavam a chamar a atenção dos políticos que viam aí a possibilidade de o município não só construir os edifícios escolares, mas também gerir toda a rede de Ensino Municipal.

O $3^{\circ}$ Convênio foi extinto em 1959, longe de alcançar a qualidade que apresentou o $2^{\circ}$ Convênio: enquanto o $2^{\circ}$ Convênio Escolar construiu 52 escolas em 5 anos, o $3^{\circ}$ construiu somente 17 escolas ao longo de, também, 5 anos de existência.

Durante sua vigência, as ações do $3^{\circ}$ Convênio estiveram muito mais voltadas à construção de galpões de madeira. Consta que, durante os dois últimos convênios, cerca de 500 galpões de madeira foram construídos visando, em um primeiro momento, a funcionar como "biruta" para medir a demanda de uma determinada região, para, posteriormente, serem substituídos por edifícios de alvenaria. Esses galpões, porém, passaram a fazer parte da paisagem da cidade durante vários anos. 
De acordo com a Revista Engenharia Municipal n 13, de 1959, as comissões Executivas e suas subcomissões foram assim compostas:

A primeira Comissão Executiva do Convênio Escolar, no período de 1949 a 1953, foi assim constituída: presidente, engenheiro José Amadei; chefe do setor de construções, engenheiro Ernesto de Faria Alves; chefe do setor de projetos, arquiteto Hélio de Queiroz Duarte e, finalmente, chefe do setor de contadoria, Celso Hahne.

Posteriormente, a presidência da referida Comissão passou pelas seguintes modificações:

de 1953 a 1954: engenheiro Werther Krause

de 1954 a 1955: o engenheiro José Amadei

de 1955 a 1955: o engenheiro Maury de Freitas Julião

de 1957 a 1955: o engenheiro Jayme da Rocha Pereira

de 1958 a 1959, o engenheiro José Olavo de Freitas

Quanto ao setor de construções:

de 1953 a 1954: engenheiro Armando de Arruda Camargo

de 1954 até 1959: engenheiro Cyro Ribeiro Pereira

Quanto ao setor de projetos [sic]:

de 1952 a 1953: arquiteto Julio Cezar Lacreta

de 1954 a 1956: arquiteto Elvio Novelleto

de 1956 a 1959: arquiteto Raul Bolliger. 
"Se a República era o lugar do 'homem novo', tornava-se necessário repensar este ambiente, organizado, higienizado, ordenando o espaço físico da cidade e, por conseqüência, o espaço físico da escola. Os prédios escolares surgem, então, com uma finalidade específica, ou seja, o lugar onde se processa a formação do cidadão." (in Dórea, 2000, pág. I) 
2.1 O CONTRADITÓRIO CONTEXTO SOCIAL E URBANO DA METRÓPOLE COSMOPOLITA NO QUAL AS ESCOLAS DO $2^{\circ}$ CONVÊNIO ESCOLAR FORAM IMPLANTADAS 
Como vimos no capítulo I, com a modernização dos sistemas escolares ocorrida no Rio de Janeiro, em 1930, durante a gestão do educador Anísio Teixeira, e, em São Paulo, a partir de 1936, com o trabalho da Comissão Permanente de Ensino, a escola pública passou a ampliar o seu papel na sociedade se definindo como espaço para a formação dos cidadãos.

As escolas na Primeira República (1889-1930) caracterizaram-se urbanisticamente por ocuparem espaços estratégicos nos centros urbanos, ao pretenderem mostrar o papel redentor que se atribuía à educação no regime republicano recémimplantado: a igreja e o campanário, tradicionais das cidades coloniais, são substituídos, respectivamente, pelo edifício escolar e pelo mastro da bandeira nacional. Essa centralidade física e a necessidade de destacar o edifício escolar no espaço urbano, através de sua monumentalidade, não subsistem à revisão do papel social da educação defendido pelos ideais escolanovistas: a centralidade física foi então substituída por uma "centralidade funcional", ou seja, uma vez que o edifício escolar passa a ser equipamento estruturador dos bairros, em conseqüência do programa arquitetônico que se incrementou, ao oferecer equipamentos urbanos como auditórios e bibliotecas, serviços de assistência social e de saúde, sua localização e número de edifícios passaram a ser estratégicos, no intuito de atender a toda população urbana.

Dessa maneira, os bairros passaram a organizar parte de seu cotidiano em função dos serviços oferecidos pelas modernas escolas escolanovistas. $\bigcirc$ caráter social conferido ao edifício escolar, na década de 50, passou a definir uma nova "centralidade" para a escola que, de monumento, rende-se à escala da criança e se dilui no cotidiano dos bairros. 
Essa mudança da função da escola dentro do espaço urbano, sua quantidade e porte ocorreram em decorrência das transformações pelas quais passaram os bairros, na cidade de São Paulo, a partir da década de 50, conseqüência do crescente processo de descentralização que começa a caracterizar as transformações urbanísticas da cidade, na proximidade de seu IV Centenário de fundação.

Assim, as escolas durante o convênio escolar, dentro desse processo de descentralização da cidade em relação ao seu centro histórico, ganham definitivamente status de equipamento público educativo e cultural, referências urbanas na formação de cidadãos, equipamentos disponíveis, não somente aos estudantes matriculados, aos quais em um primeiro momento se destinava, mas também a seus pais e vizinhos que compartilhariam o mesmo espaço físico: nas reuniões de bairro que ocupariam as salas de aula em horários de ociosidade, alfabetização de adultos em cursos noturnos, uso de seus espaços livres para atividades físicas e recreativas, bibliotecas, salas de artes, museus de exposição e no uso do pátio coberto, equipado com palco para as mais diversas apresentações artísticas. 


\subsubsection{A CIDADE SE REVELA EM SUAS CONTRADIÇÕES NOS PREPARATIVOS PARA A COMEMORAÇÃO dO IV CENTENÁRIO DE FUNDAÇÃO}

No período de 1951 a 1954, a cidade de São Paulo preparou-se oficialmente para a comemoração do IV Centenário de sua fundação. Seu caráter metropolitano e cosmopolita de maior Parque Industrial Latino-Americano cobrava-lhe uma tomada de posição quanto ao grave desequilibrio social que se revelava na contramão de seu vertiginoso desenvolvimento econômico. Assim, para as comemorações do IV Centenário, a Câmara Municipal de São Paulo aprovou em setembro de 1951, o Plano de Melhoramentos Públicos. $\bigcirc$ plano representou somente uma proposta de melhorias urbanas e não a proposição de um conjunto de ações que, planejadas ao longo do tempo, pudessem construir um plano urbanístico para a metrópole que se definia.

Várias equipes constituíram-se para a viabilização desse plano, e merece destaque a Equipe de Planejamento, liderada pelos arquitetos Eduardo Kneese de Mello e İcaro de Castro Mello que defenderam ser de fundamental importância a elaboração de um plano diretor que ordenasse o crescimento da cidade: as comemorações do IV Centenário deveriam ensejar a possibilidade de se planejar o futuro da cidade, contemplando seu equilíbrio social e econômico e, por isso, os arquitetos colocaram em discussão a necessidade de frear o vertiginoso crescimento da capital paulista tendo em vista o grave desequilíbrio social sobre o qual ele se sedimentava. Esse plano diretor não se efetivou.

Com as obras do Plano de Melhorias, a cidade, a partir de 195 I, transformouse em um gigantesco canteiro de obras como não se via desde o Plano de Prestes Maia

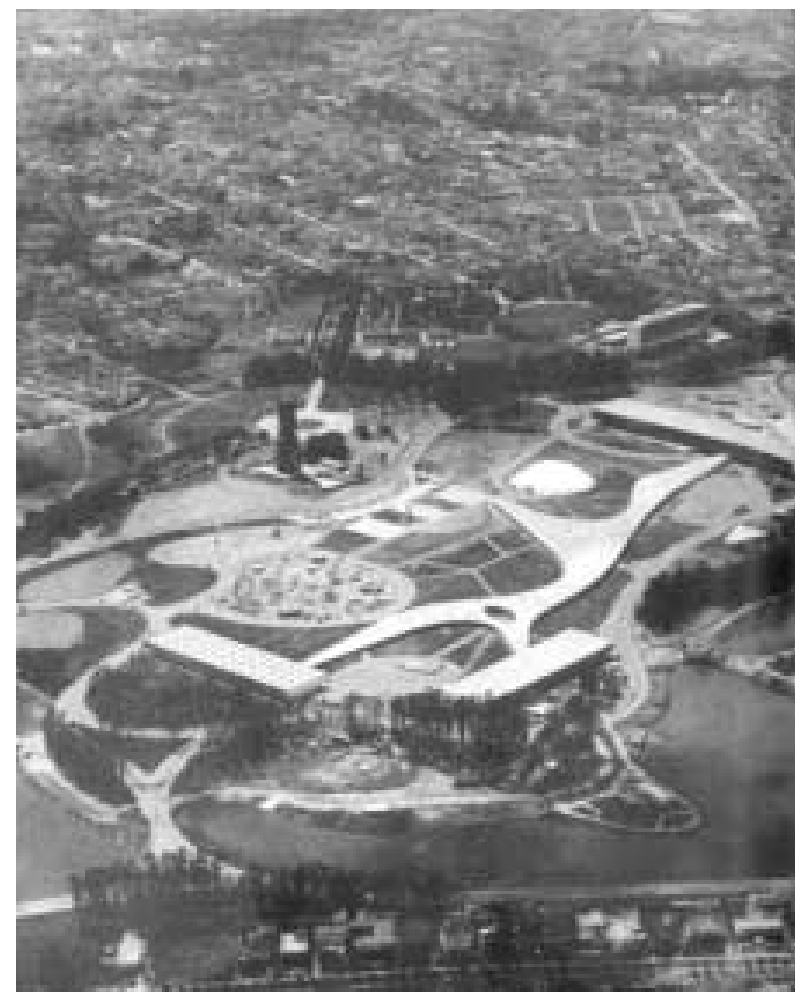

PARQUE dO IBIRAPUERA, 1954 - DeSTAQUE dAS COMEMORAC̄̃eES DO IV CENTENÁRIO 
de 1930. Obras de saneamento foram realizadas, através da construção de 18 galerias para escoamento das águas pluviais; pontes e viadutos foram construídos, como a estratégica ponte de acesso à Via Anhanguera; outras pontes já existentes foram substituídas por estruturas mais modernas como a Ponte da Freguesia do Ó, Ponte do Limão, Ponte da Casa Verde, Ponte dos Remédios e Ponte Metálica da Armour.

"O Programa Quadrienal de Obras e Melhoramentos tinha também como meta a execução de avenidas cujos projetos datavam da década de 30. Com origem no "Plano de Avenidas", algumas destas artérias foram reavaliadas pelo Departamento de Urbanismo que apenas atualizou as propostas elaboradas por Prestes Maia. Faziam ainda parte deste agrupamento de melhoramentos, a Avenida Leste (Radial Leste), a Avenida Anhangabaú-Tiradentes (Radial Norte), a Avenida Anhangabaú Superior (antiga Itororó e atual 23 de Maio), a Avenida Sumaré, a Avenida Água Funda, a Estrada de Santo Amaro e as Avenidas Marginais do Tietê no trecho Osasco e Guarulhos." (in Meyer, 1992, pág. 52)

Através de volumosas obras de infra-estrutura viária, a cidade conectava seu centro aos bairros, que se consolidavam. Evidenciando o caráter de descentralização contido no plano em relação ao seu centro histórico, foram construídos o mercados distrital de Osasco, então pertencente ao município de São Paulo, e o mercado distrital do bairro da Lapa.

A área cultural foi, sem dúvida, uma das mais privilegiadas, com a construção (sob a responsabilidade e custeio da Prefeitura Municipal) do Parque do Ibirapuera, onde a grande exposição do IV Centenário aconteceu. Cenário moderno, seus edifícios e marquises foram projetados por equipe liderada por Oscar Niemeyer, então o arquiteto 
com maior prestígio em nosso país. $O$ projeto dos espaços livres ficou sob a responsabilidade do paisagista Burle Marx, substituído depois pelo projeto do engenheiro Otavio Augusto Teixeira Mendes.

O projeto do Parque Ibirapuera trouxe para a cidade paulistana um sinuoso e moderno parque concebido para a "vida urbana da luz, do verde e do ar", de acordo com o que havia de mais contemporâneo na arquitetura nacional, então reconhecida internacionalmente em sua singularidade. Dessa maneira, a burguesia industrial pretendeu registrar no espaço físico da cidade paulistana, em seu aniversário de 400 anos, a modernidade arquitetônica.

As propostas do Plano de Melhorias visaram a atenuar os efeitos de uma cidade que crescia sem qualquer planejamento e que, por conseqüência, gerou grandes vazios urbanos, privilegiando, através de seu especulativo mercado imobiliário, somente a região central e adjacências.

Conforme descreveu Luis Saia, a cidade de São Paulo, em 1954, havia crescido substancialmente: dos 130 km² em 1930, para uma área de $420 \mathrm{~km}^{2}$, e esse crescimento deveu-se, em grande parte, à expansão do mercado imobiliário que, sem qualquer traço de planejamento urbano, resultou em loteamentos e bairros desconectados, carentes de serviços básicos e de infra-estrutura urbana. Saia também descreveu que o processo de industrialização, em substituição à economia monocultora do café impulsionou esse crescimento e transformou a cidade em metrópole, ao conectá-la regionalmente às cidades do ABC, Guarulhos, Osasco, São Miguel e Santo Amaro, que passaram a participar do mesmo processo de industrialização atendendo à diversificação da produção de manufaturas, característica da produção industrial. Assim, o mesmo processo de regionalização, que conectou esses municípios em torno da monocultura cafeeira,

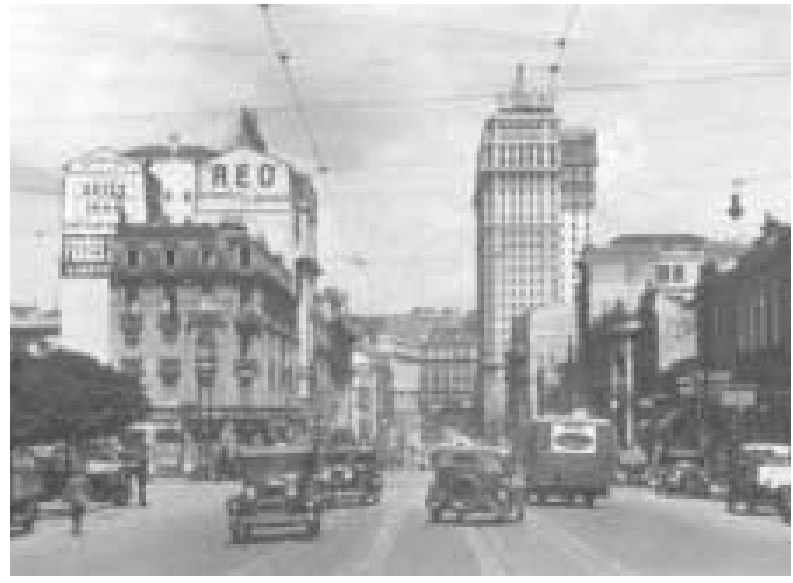

SÃO PAULO ANOS 30

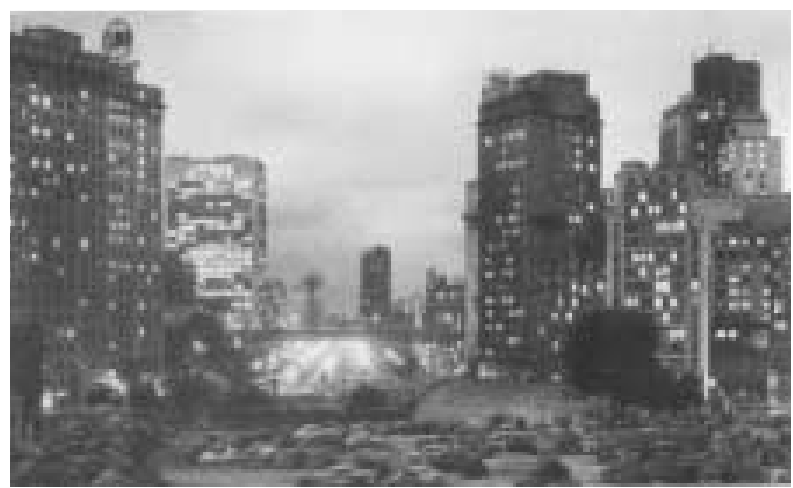

SÃO PAULO ANOS 50 
possibilitou a transformação da economia na diversificação da produção industrial: a conexão dos municípios, em função da economia monocultora, transformou-se indutora do processo de diversificação característico da economia industrial.

Em sua tese de doutorado "Metrópole e Urbanismo - São Paulo Anos 50", Regina Meyer ao descrever as conclusões de Luis Saia, reforça a tese de crescimento espacial horizontal metropolitano, através, também das teorias de Langenbuch:

"Com base nos censos demográficos de 1940, 1950 e 1960 e com dados divididos por subdistritos e distritos, Langenbuch conclui que o aumento da população foi de 207\%, e o que é essencial: o rebatimento espacial deste crescimento foi maior nos 'arredores' do que na 'cidade'. Segundo os dados apresentados, a 'cidade' cresceu $171 \%$ e os 'arredores' 364\%. Langenbuch atesta assim a tese de que a intensa verticalização da área central da cidade, sem dúvida alguma uma das fortes características do período, é objetivamente menos intensa do que a vigorosa compactação horizontal periférica". (in Meyer, 2002, pág. 15)

Langenbuch em sua teoria abrangeu dois períodos: o primeiro de 1915 a 1940, quando ocorreu a verdadeira metropolização, e um segundo, de 1940 a 1954. No primeiro período, Langenbuch descreveu um cenário urbano que vai além daquele verticalizado e concentrado em seu centro histórico e que se caracterizou por revelar a grande extensão horizontal de nossa cidade; o segundo período descrito caracterizou-se pela conexão regional, viabilizada pela construção de rodovias, de loteamentos e de conjuntos habitacionais modernos que se destacaram na paisagem por sua homogeneidade de tratamento. 
No primeiro período (1915-1940), São Paulo passou a se caracterizar por um grande crescimento horizontal, através da construção dos novos loteamentos promovidos pela especulação imobiliária, que foram implantados desconectados dos bairros já consolidados.

Dentro desse processo de crescimento horizontal desordenado, destacamos duas modalidades de subúrbio:

- subúrbios industrial-residenciais que, segundo a análise de Langenbuch, tiveram sua implantação condicionada ao trinômio ferrovia, terrenos grandes, planos e baratos e água fluvial - os chamados subúrbios-estação;

- subúrbios que surgiram em função de loteamentos conectados através de ônibus, que chegaram a esses novos bairros depois de as pessoas aí já terem se fixado e reivindicado esse meio de transporte.

Se o caminho do trem costurou os bairros em linha, com a racionalidade dos trilhos, os ônibus possibilitaram a expansão da cidade por regiões totalmente desconectadas da cidade existente e obedecendo somente a lógica da especulação da terra urbana.

No segundo período, a partir de 1940, a nova paisagem suburbana de São Paulo passou a ser construída ao longo das rodovias que, conectadas para o escoamento da produção industrial, costuraram o tecido regional.

“...Via Anchieta, Via Anhanguera e Via Dutra - como agentes do desenvolvimento suburbano, verdadeiros eixos em escala regional. Além de estimular o desenvolvimento suburbano em seus domínios, as auto-estradas se mostraram propícias à industrialização nas suas bordas, resultando em uma nova paisagem 
industrial. Implantadas em grandes áreas ajardinadas, as industrias passam a explorar a visibilidade propiciada pela via. Um indiscutivel caráter moderno marca a instalação destas indústrias." (in Meyer, 1991, pág. 15)

Outra paisagem que passou a caracterizar as áreas suburbanas foi a dos conjuntos habitacionais homogêneos, produzidos em escala industrial por iniciativa do Estado ou da iniciativa privada, repetindo, entretanto, os mesmos problemas de falta de equipamentos urbanos dos demais subúrbios existentes.

Esta breve caracterização dos bairros da cidade de São Paulo e seu incipiente processo de urbanização, em resposta a um crescimento demográfico exponencial, provocado pelo vertiginoso desenvolvimento da indústria e sem a intervenção de qualquer órgão planejador do Estado, têm a função de ilustrar a dificuldade em planejar a construção de escolas em um território que se espalhava sem qualquer critério, nas décadas de 40 e 50. Atender à criança em um território tão disperso e heterogêneo e com o princípio de educar para "viver na cidade", fizeram das escolas construídas pelo $2^{\circ}$ Convênio Escolar equipamentos essenciais na qualificação dos bairros suburbanos e na vida de suas crianças.

A Comissão Executiva do $2^{\circ}$ Convênio Escolar iniciou, em 1949, seus trabalhos com uma científica e detalhada pesquisa, levando em conta o crescimento demográfico dos 4 I distritos que compunham a cidade e a demanda por escola de cada um deles, a partir da população infantil existente em idade escolar e, para tanto, incluiu visitas às áreas a serem atendidas e o levantamento dos problemas no próprio local.

As escolas do convênio e seu princípio de educar cidadãos revelaram, também, uma postura que se alinhava com os desejos da burguesia industrial que 
São Paulo até o início da década de 30. A década de 40 mostrou-nos que o processo de construção de uma sociedade urbana já se apresentava irreversível na cidade paulistana.

Educar para viver na cidade, instruir para que o filho do trabalhador pudesse servir à indústria, e por conseqüência, usufruir de seus benefícios, era parte do ideal que alimentava os novos extratos sociais advindos do desenvolvimento de uma sociedade urbana e industrial.

A mudança da sociedade revelou-se, também, nos novos hábitos adquiridos e, por decorrência nas novas necessidades, a serem atendidas. Assim, a educação e a cultura, o acesso à arte e ao cinema passou a fazer parte do cotidiano do cidadão paulistano. 


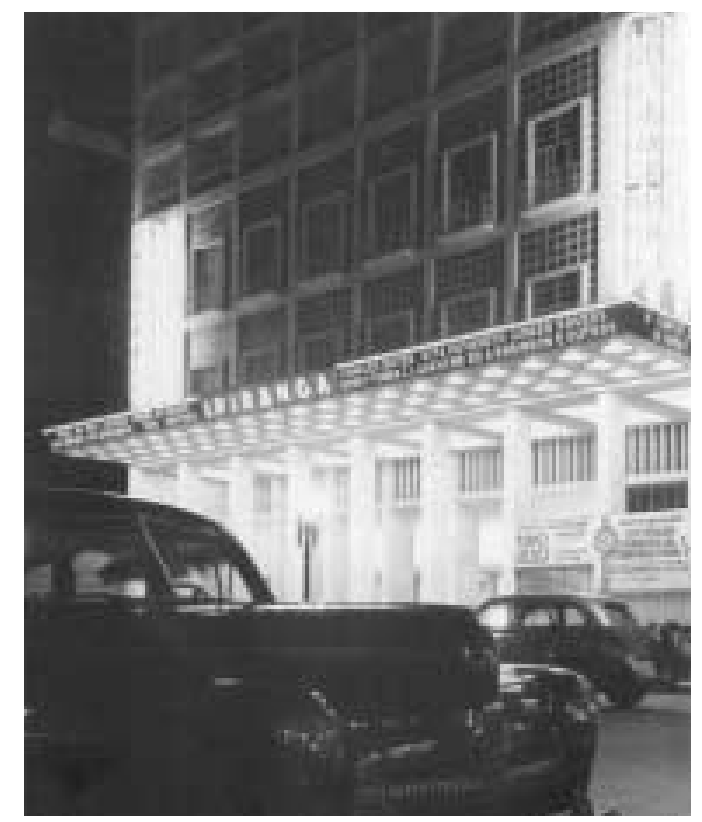

CINE IPIRANGA E HOTEL EXCELSIOR - ARQUITETO RINO LEVI, 1941

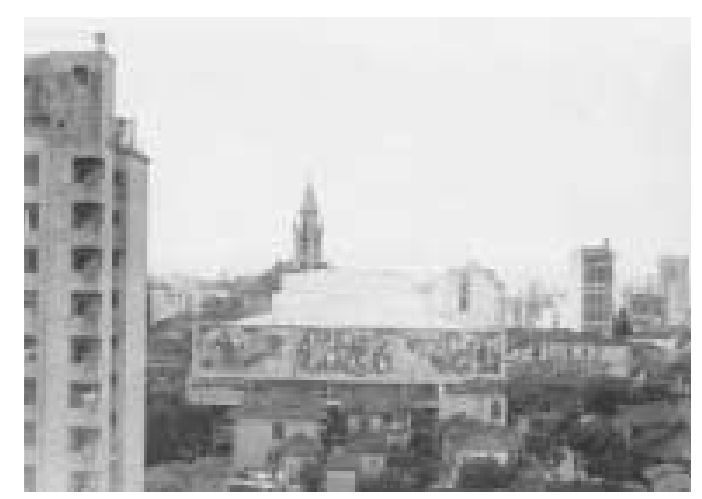

TEATRO CULTURA ARTÍSTICA - ARQUITETO RINO LEVI, 1942/1943

\subsubsection{OS NOVOS HÁBITOS CULTURAIS PAULISTANOS}

Na década de 50, a cidade de São Paulo já ocupava lugar de destaque no cenário cultural nacional e internacional; um meio cultural urbano e cosmopolita que guardava, na complexidade de seu tecido social, diversas formas de representação cultural - se a geração modernista da década de 20 perseguia nossa identidade, através do nacionalismo, o "ser moderno" da década de 50 perseguiu o cosmopolitismo como uma forma de nos inserirmos no mundo:

"A cidade dos italianos está definitivamente superada, a diversidade dos imigrantes justifica a observação de Oswald de Andrade de que São Paulo tornarase naquele momento uma sociedade das nações urbana. Entretanto, apesar desta transformação ter grande significado para a vida metropolitana, pois as influências culturais se diversificaram enormemente, ela não era a responsável nem direta nem única do novo cosmopolitismo paulistano.

O cosmopolitismo dos anos 50 difere do anterior por não ser apenas a somatória de indivíduos estrangeiros presentes na sua população. Na sua nova acepção, o cosmopolitismo paulistano baseava-se em novos valores. Pertencer ao mundo, ser homem do mundo era então o ideal que se manifestava na sociedade paulistana da década de 50. 0 desenvolvimento industrial, a presença do capital estrangeiro, a modernização da vida cotidiana, criavam a expectativa de transformar esta aspiração em realidade palpável." (in Meyer, 1992, págs. 48 e 49)

O espaço físico da cidade de São Paulo refletiu sua modernidade nos novos programas arquitetônicos voltados à cultura. Desde o final da década de 40, São 
Paulo contava com dois museus - O Museu de Arte de São Paulo (MASP), fundado em 1947 por Assis Chateaubriand, e o Museu de Arte Moderna (MAM), criado em 1948 pelo industrial Francisco Matarazzo Sobrinho, no qual se instalou, em 1951, a

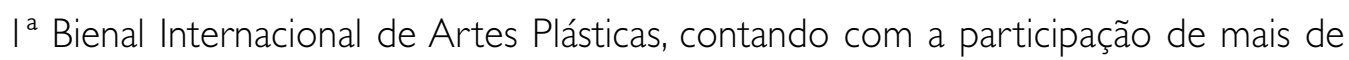
20 países e visitada por mais de 20.000 pessoas. A primeira televisão, a TV TUPI, foi ao ar em 1950, sacramentando a sociedade de massas que se consolidava.

Na década de 50, São Paulo já contava com 119 cinemas freqüentados por 35 milhões de espectadores ao ano (in Meyer, 1992, pág. 36). O circuito constituído pelas avenidas Ipiranga e São João e arredores formavam a Cinelândia paulistana, com cinemas que foram sendo construídos a partir da década de 30. Em 1936, foi inaugurado o Ufa-Palace, projeto do arquiteto Rino Levi com 3.139 lugares que, exemplar, foi adotado como modelo e fez de seu arquiteto referência no domínio da técnica para desenvolvimento de projetos de salas de projeção.
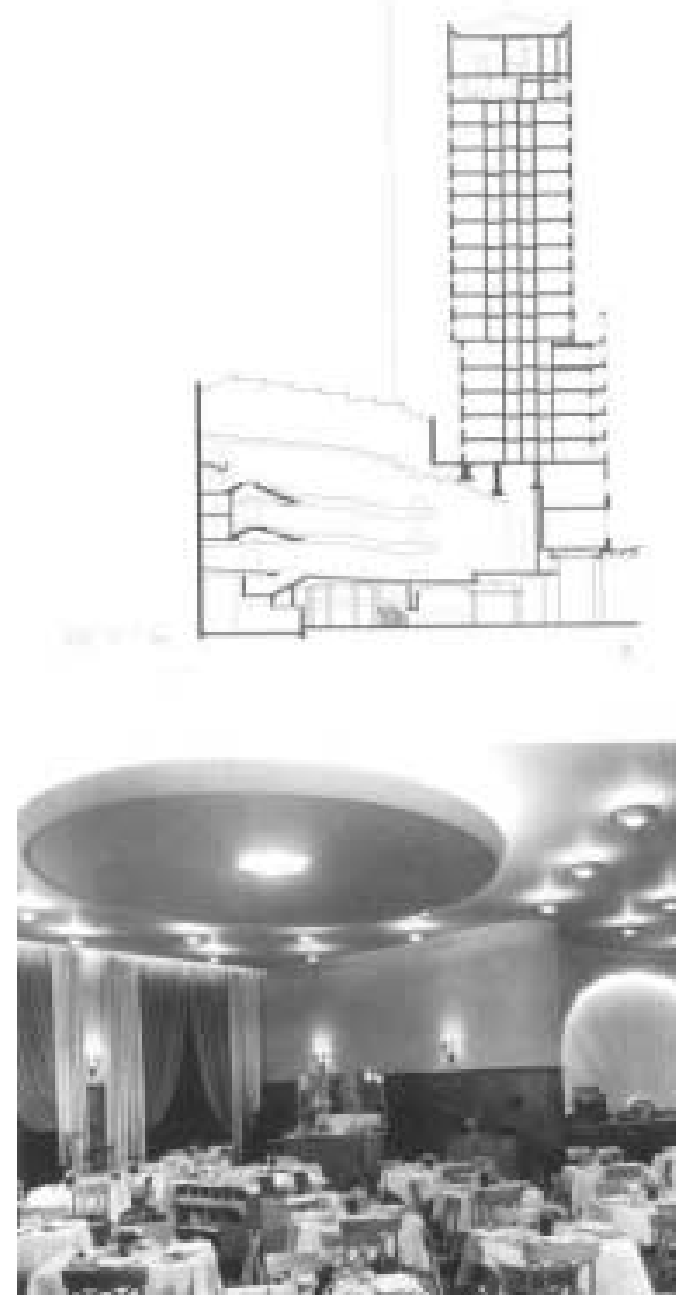

CINE IPIRANGA E HOTEL EXCELSIOR - CORTE LONGITUDINAL E RESTAURANTE DA COBERTURA DO HOTEL 


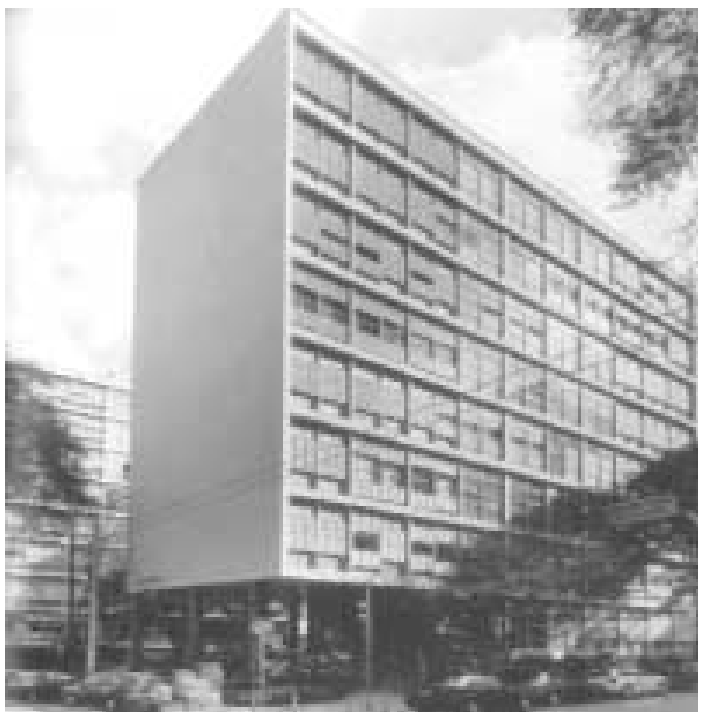

EDIFÍIIO LOUVEIRA - ARQUITETO VILANOVA ARTIGAS 1946

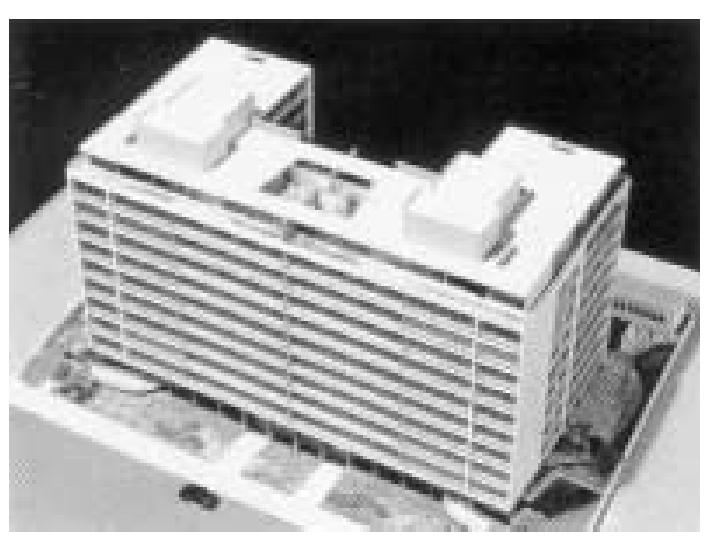

EDIFICIO PRUDÊNCIA - ARQUITETO RINO LEVI, 1948

\subsubsection{OS NOVOS HÁBITOS DE MORAR NA CIDADE PAULISTANA}

A intensa verticalização da área central da cidade levou os paulistanos a adquirirem novos hábitos de moradia - os condomínios verticais foram uma conseqüência desse processo - morar na cidade passou a significar morar com densidade, ao menos para uma parcela da população que podia usufruir de seu centro econômico e financeiro e dos bairros diretamente a ele relacionados.

Desde a década de 50, os condomínios verticais ofereciam na base de suas torres, serviços de recreação e comércio, a partir de uma arquitetura comprometida com a moderna escola de arquitetura internacional.

Regina Meyer nos descreve, sucintamente, uma cronologia da produção de edifícios verticais para habitação, entre as décadas de 40 e 50:

"Ao abrir a década de 50 a cidade de São Paulo já contava com um número razoável de edifícios de apartamentos, cujas propostas arquitetônicas mostravam sintonia com a arquitetura erudita internacional e mais intensamente com o Movimento Moderno. Os mais representativos exemplos destes edifícios residenciais são seguindo uma ordem cronológica: o edifício Columbus, projeto do escritório Rino Levi Arquitetos Associados, situado na Avenida Brigadeiro Luiz Antônio, no ano de 1932; o edifício Esther, dos arquitetos Álvaro Vital Brasil e Adhemar Marinho, inaugurado em 1935 na Avenida Ipiranga; o Edifício Santarém, projeto de Henrique Mindlin, na Rua Barão de Campinas, do ano de 1940; 0 Edifício Anchieta, de 1941, projetado pelos irmãos Marcelo Roberto e Milton Roberto, situado na esquina da Av. Angélica com a Av. Paulista; o Edifício Louveira, projeto de Vilanova Artigas e Carlos Cascaldi, situado na Praça Vilaboim, de 1946 e o Edifício Prudência, de 1948, projeto de escritório Rino Levi Arquitetos Associados, situado na Avenida Higienópolis." (in Regina Meyer, 1992, págs. 36 e 37) 
Por outro lado, se os bairros centrais ou os bairros a eles diretamente ligados tinham garantidas as benesses de uma sociedade moderna, industrial e urbanizada, outra grande parte do território do município - sua maior parte - representada pelos subúrbios de estação ou subúrbios de loteamentos ficaram à margem deste processo de modernização, relegados ao esquecimento do Estado. Sua população amontoavase, sem equipamentos ou infra-estrutura urbana, nos cortiços de periferia e nas casas auto-construídas.

A real situação destes bairros periféricos foi detalhadamente revelada somente com a contratação da Sociedade para a Análise Gráfica e Mecanográfica Aplicada aos Complexos Sociais (SAGMACS).

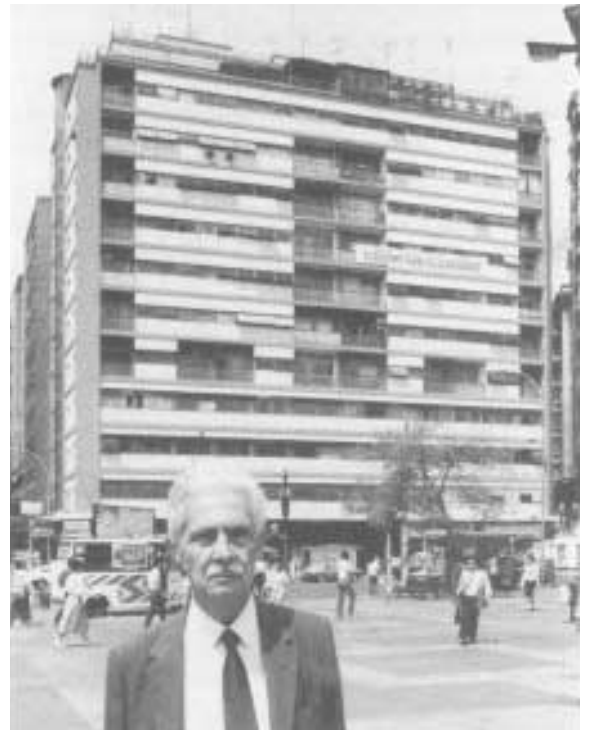

EDIFÍCIO ESTHER - ARQUITETO ÁLVARO VITAL BRASIL, 1935

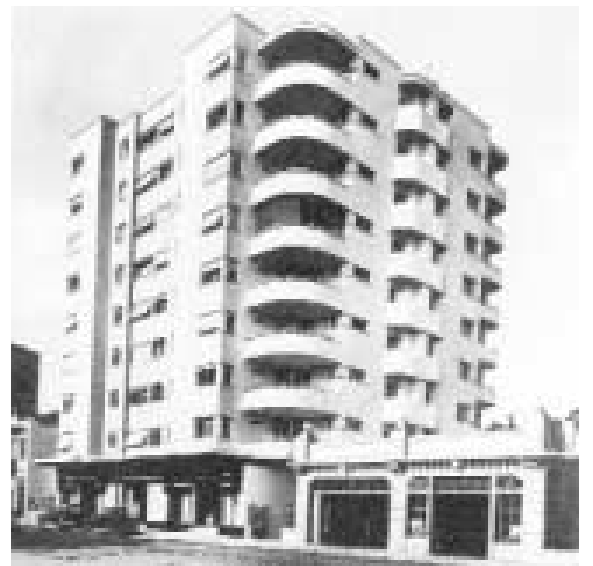

EDIFÍCIO COLUMBUS - ARQUITETO RINO LEVI, 1932 


\subsubsection{A SAGMACS E A REVELAÇ̃̃O DA CIDADE REAL}

Durante o Governo de Lucas Nogueira Garcez (1951 a 1953), a SAGMACS (Sociedade para a Análise Gráfica e Mecanográfica Aplicada aos Complexos Sociais), fundada no Brasil em 1948 pelo Padre Lebret, promoveu um estudo sobre as possibilidades e necessidades do Estado de São Paulo e, em 1956, a mesma SAGMACS foi contratada para elaborar uma pesquisa, visando a analisar e diagnosticar detalhadamente a cidade de São Paulo, e que se constituiu em um marco na formação dos urbanistas paulistanos.

Tratou-se de um estudo voltado ao planejamento e desenvolvimento equilibrado de todo o território urbano, priorizando a instalação de equipamentos urbanos para toda a população, que só poderiam ser planejados por meio do conhecimento da cidade real, de suas carências e potencialidades. É através dessa postura no enfrentamento de seus desequilíbrios, que podemos identificar na história de nossa cidade um conjunto de profissionais que trabalharam na convergência de um projeto humanista, com a intenção de reduzir e denunciar as desigualdades sociais da cidade de São Paulo.

As escolas propostas pelo $2^{\circ}$ Convênio Escolar, com seu programa arquitetônico abrangente, foram parte desses equipamentos urbanos que, além de educar para o ensino tradicional, extrapolaram, em seu espaço físico, para as possibilidades de encontro entre as pessoas, na discussão de seu cotidiano. Hélio Duarte, chefe da equipe de arquitetura do "Convênio Escolar", na revista Habitat n 4, ao apresentar as primeiras escolas, confirma esta constatação: 
"Por que não considerar em cada bairro - a escola, o grupo escolar, como fonte de energia educacional, como ponto de reunião social, como sede das sociedades amigos de bairro, como ponto focal de convergência dos interesses que mais de perto dizem com a vida laboriosa de suas populações?

Nela com o aproveitamento integral do prédio, em rodízio de um farto número de horas, poderíamos, a par da educação ministrada à noite a adultos, recrear e educar um grande número de pessoas.

A escola passaria a ser um verdadeiro cadinho do amálgama da nossa heterogênea população. Reuniões de pais, pequenos bailes, cursos para as mães e noivas, pequenas palestras, cinema e teatro educativos, biblioteca, audições de música, teatro de bonecos e jogos. Tudo aí poderia ser realizado. Forças centrípetas convergiriam para a escola e seriam as concorrentes da formação intelectual, social, e profissional dessas pequenas comunidades, onde depois de processadas passariam a ser as forças centrífugas - difusoras do conhecimento adquirido. "

A visão orgânica de cidade, apresentada pela SAGMACS é reforçada pela visão humanista esboçada pelo arquiteto Hélio Duarte em sua coordenação nos trabalhos do "Convênio Escolar", sem que uma tenha servido diretamente para alimentar os ideais da outra. Na realidade, as duas atenderam à mesma "causa" social que caracterizou, de acordo com Anatole Kopp, o movimento genuinamente moderno: ambas as visões moveram-se pelo sonho de uma sociedade humana e igualitária - a equipe liderada por Hélio Duarte, na escala do edifício que só se faz completo com a visão da cidade, e a SAGMACS, na escala da cidade que só se completa no pleno atendimento dos serviços de saúde, educação, justiça e infraestrutura urbana de sua população.

A cidade, através do diagnóstico apresentado pela SAGMACS, revelou todas as suas faces, escancarando aquela da periferia improvisada para a moradia do 
trabalhador urbano, excluído que foi do espaço central da cidade paulistana. Nabil Bonduki, em seu livro "Origens da Habitação Social no Brasil", aponta a situação que encontramos na periferia paulistana, no início da década de 50, e a conseqüência política desse abandono: terreno fértil para a demagogia populista.

Podemos concluir que, junto à ideologia apregoada pelas escolas do "Convênio Escolar", dentro de um processo de descentralização do poder pelo qual passava o país naquele momento, vimos o surgimento do populismo que se apossou dos ideais de cidade e transformou-os em peças de um jogo eleitoreiro e pseudodemocrático. Montou-se, assim, o campo de batalha entre os arquitetos, com sua técnica e seus projetos, e o jogo demagógico dos políticos populistas.

Podemos concluir também que, apesar de não fazer parte do "Programa de Melhoramentos Públicos de 195 I", que teve na construção do Parque do Ibirapuera sua maior expressão, em função das comemorações do IV Centenário da cidade, o "Convênio Escolar" fez parte de um conjunto de intervenções na cidade paulistana na década de 50 que visava a "correr atrás" dos anos de desprezo relativos às questões voltadas à carência de escolas e às primeiras considerações com os distantes bairros operários suburbanos. 
2.2 NO CONTEXTO DA PRODUÇÃO ARQUITETÔNICA NACIONAL AS DEFINITIVAS INFLUÊNCIAS DA HEGEMÔNICA ARQUITETURA CARIOCA NA LINGUAGEM ADOTADA PARA AS ESCOLAS DO $2^{\circ}$ CONVÊNIO ESCOLAR 
"Contudo, para melhor situar as razões e significados contidos nesses projetos, será preciso retomar os princípios espaciais que governam a revolução moderna na arquitetura, considerando, para o caso brasileiro, a penetração predominante da vertente corbusiana. Quer dizer, a idéia de construções "amplas, horizontais, espaçosas, no meio de jardins", pressupõe uma compreensão da relação entre edifício e espaço urbano completamente distinta da que se consolidou nas cidades tradicionais européias da metrópole e da colônia: edifícios relativamente uniformes, respeitando os gabaritos e alinhamentos dos lotes, e definindo pátios centrais fechados nos miolos das quadras". (Wisnick no livro Arquitetura Escolar Paulista anos 50 e 60, 2006, pág.62)

Desde Mário de Andrade, com os parques infantis paulistanos, na década de 30, a arquitetura voltada à educação procurou expressar a busca por uma identidade nacional. A experiência adquirida com o Neocolonial, que cativou em um primeiro momento Mário de Andrade e até mesmo Lúcio Costa, deve ser avaliada como parte de um processo que levou à definição de uma linguagem arquitetônica singular e que culminou na moderna arquitetura carioca.

A trajetória para a invenção dessa linguagem arquitetônica, legitimada como expressão cultural brasileira, tem sua gênese no rígido racionalismo europeu, que orientou a concepção de nossos primeiros edifícios modernos, como classificamos as escolas construídas por Enéas Silva, na década de 30, no Rio de Janeiro, ao lado do educador Anísio Teixeira, e as escolas construídas pela Comissão Escolar, em São Paulo, a partir de 1936, pelos arquitetos José Maria das Neves e Hernani do Val Penteado.

Vimos também que o rígido racionalismo presente nessas primeiras escolas refletiu-se somente na composição de seus arranjos espaciais, apresentando uma 
roupagem art decô em sua forma final.

As escolas do $2^{\circ}$ Convênio Escolar, a partir de 1978, por sua vez, definiram sua linguagem arquitetônica a partir da arquitetura moderna carioca, então consagrada internacionalmente, como representante máxima da arquitetura moderna brasileira.

Essa linguagem se originou a partir dos ensinamentos de Le Corbusier, com o qual alguns de nossos primeiros arquitetos modernos brasileiros puderam dividir a prancheta, na elaboração do projeto do Ministério da Educação e Saúde, na gestão do Ministro Gustavo Capanema, em 1937, sob o comando do arquiteto Lúcio Costa.

O percurso entre o austero racionalismo do início dos anos 30 até as orgânicas e plásticas formas da arquitetura carioca é contado a partir das experiências de engajados e idealistas arquitetos como Eduardo Affonso Reidy que, como veremos a seguir, resultaram das mudanças implementadas pela direção de Lúcio Costa na Escola Nacional de Belas Artes, ao romper com o ensino de arquitetura clássico ortodoxo e substituí-lo pelo ensino dos modernos conceitos da arquitetura internacional, a partir dos cinco pontos propagados por Le Corbusier para uma nova arquitetura.

O ornamento clássico ou eclético não teria nenhuma razão de ser para um arquiteto comprometido com o desenvolvimento de um país moderno e industrializado, afinado com a construção de um espírito nacional e a serviço de um povo que, urbanizado, teria acesso a uma moderna vida com qualidade.

O percurso dessa busca tem seu desfecho em obras como o Ministério da Educação e Saúde, coordenado por Le Corbusier, o Pavilhão Brasileiro, projetado por Lúcio Costa e Oscar Niemeyer para a Feira Mundial de 1939, em Nova York e com a importante exposição Brazil Builds no MoMa de NY. 


\subsubsection{BREVE HISTÓRICO PARA COMPREENSÃO DA HEGEMONIA DA ARQUITETURA CARIOCA NO CENÁRIO NACIONAL}

A hegemonia da escola moderna carioca deveu-se, entre outras coisas, ao fato de essa moderna arquitetura ter tido como mecenas o Governo Federal de Getúlio Vargas (não se tratou de torná-la arquitetura oficial, mas de seu uso oportuno por alguns de seus ministros e colaboradores, identificados com a busca por uma identidade nacional para nossa arquitetura). Exemplo dessa intenção foi dado pelo Ministro Gustavo Capanema que dirigiu a contratação de jovens arquitetos cariocas, sob a coordenação de Lúcio Costa, para a execução do projeto da sede do Ministério da Educação e Saúde com o acompanhamento do mestre Le Corbusier e também pelo fato de os arquitetos, que se espalhavam pelo país, deverem sua formação ao curso de arquitetura da Escola Nacional de Belas Artes do Rio de Janeiro, após a curta e transformadora gestão de Lúcio Costa.

No Rio de Janeiro, os arquitetos, desde a palestra proferida por Le Corbusier na Escola Nacional de Belas Artes, em 1929, passaram a ter um primeiro contato com suas revolucionárias idéias na propagação dos ideais modernistas por toda a América Latina. A obra de Le Corbusier passou a ser referência fundamental, para a produção de nossas primeiras obras com explícita linguagem moderna.

"A sedução que ela exercia pode ser explicada pela unidade do sistema proposto, que partia de ordem econômica e social, de um lado, e de argumentos de ordem técnica de outro, culminando numa concepção artística. Seu espírito dogmático atraĺa os jovens espíritos, um tanto desorientados, na procura de um caminho; oferecia, ao mesmo tempo, um ideal, regras precisas e uma disciplina que podiam servir de referências e orientar os inseguros passos iniciais". (in Bruand, 1981, pág. 74). 
Para Lúcio Costa, entretanto, não foi esse primeiro contato com Le Corbusier que o cativou; sua importância e a descoberta da consistência de sua obra só foram consideradas, após conhecer por escrito suas teorias, em período posterior à sua saída da direção da Escola Nacional de Belas Artes. Lúcio Costa aceitou o cargo de diretor do curso de arquitetura por seu descontentamento com o ensino tradicional e por estar alinhado com o estilo Neocolonial, então compreendido como aquele que exprimia nossa nacionalidade.

No início, não despertou oposição, mas ela começou a acontecer à medida que aplicava as mudanças que achava necessárias, a começar pela demissão de professores defensores do ensino tradicional e contratação de novos professores como Gregori Warchavchik (que despontava, desde seu manifesto modernista de 1925, como liderança na defesa da arquitetura moderna no Brasil), Affonso Eduardo Reidy (jovem arquiteto formado pela Escola Nacional de Belas Artes e defensor da arquitetura racional exemplificada pelo projeto vencedor no concurso para o Albergue da Boa Vontade) e Alexander Buddeus introdutor de publicações européias que difundiam conceitos do racionalismo europeu (Segawa, 2002, pág 78). Para exemplificar o impacto dessas novas idéias, vejamos o que defendia Buddeus:

"O modernismo não é uma evolução do tradicional, isto é dos valores artísticos do passado, mas uma criação integral do nosso tempo. A orientação moderna é construtiva, social e econômica, ao passo que a orientação tradicional era artística, decorativa, simbólica." (in Santos, 19777, pág. 108)

Dessa maneira, Lúcio Costa, ao se mostrar disposto a mudanças radicais que pouco tinham a ver com as propostas neocoloniais, foi exonerado da direção da Escola 
Nacional de Belas Artes, mesmo antes de completar um ano no cargo, no entanto esse tempo foi suficiente para marcar uma geração inteira de estudantes que por lá passaram e que, formados, começaram a projetar, a partir dos pressupostos aprendidos nesse movimento reformador.

Após sua saída da Escola Nacional de Belas Artes, Lúcio Costa enfrentou um período de ostracismo, que o levou a refletir com profundidade sobre suas convicções modernas, através das leituras sobre esse movimento, de acordo com suas declarações em entrevista a Hugo Segawa:

(...) "foi então, nessa época, que tomei conhecimento a fundo, de verdade, de todo esse movimento que havia ocorrido na Europa (...) Aí comecei a tomar conhecimento da obra de Le Corbusier e me apaixonei, porque ele era extraordinário, tanto na paixão que tinha pelo que estava fazendo como foi o único daqueles arquitetos que trabalharam na época, todos extraordinários - o Gropius, o Mies Van der Rohe - que fez uma abordagem completa do movimento do ponto de vista social, do ponto de vista tecnológico, das novas técnicas construtivas, e do ponto de vista plástico, ponto de vista das artes. Ele reunia esses propósitos abrangentes; os outros cuidavam da arquitetura, mas nunca em uma abordagem global. (Le Corbusier) Criou um movimento unânime no sentido de encarar essa possibilidade de transformações tanto no campo da arquitetura e do urbanismo como do ponto de vista social, pois havia uma coincidência. Na época estávamos convencidos de que uma coisa era vinculada a outra, tendo as mesmas origens, na revolução industrial. Essa arquitetura nova que vinha surgindo destinava-se a uma nova era social, uma nova época, porque parecia que as coisas iam se encaminhar num sentido muito claro. Havia uma certa ética, uma coisa de cunho moral até, um apego de não se permitir liberdades que não se enquadrassem bem dentro dessa concepção sociológica." (in Segawa, 1987, pág. I 47) 
As reflexões de Lúcio Costa, publicadas no livro de sua autoria "Razões da Nova Arquitetura" elaborado, em 1934/ 1935 serviram para propagar, entre os arquitetos brasileiros, os ideais da arquitetura moderna que então passou a defender com convicção.

Uma importante fonte de informações a respeito do movimento moderno e seus resultados no Brasil e no exterior foi a revista PDF, publicada pelo Departamento de Engenharia e Obras Viárias do Distrito Federal. Fundada em 1932, a revista serviu para difundir o movimento moderno na arquitetura ao publicar desde projetos modernos nacionais não construídos como também idéias e conclusões do movimento moderno internacionais, defendidas nos pelos Congressos Internacionais de Arquitetura Moderna (CIAMs).

"Vários anteprojetos de concursos em linha moderna não aproveitados eram divulgados nas suas páginas (sede da associação Brasileira de Imprensa, Aeroporto Santos Dumond, cidade operária de Vila Monlevade). Um melhor conhecimento sobre insolação e iluminação (fundamental para o desenho de brise-soleil) derivou dos estudos de um colaborador da PDF, o engenheiro Paulo Sá. A revista serviu também como veículo de informações arquitetônicas internacionais: notícias sobre os CIAMs, Cirpac, os grupos Presens ZP (polonês), Gatepac (espanhol), Mars (inglês) e Tecton (do qual se publicou o Penguin Pool, cujas rampas certamente influenciaram os arquitetos brasileiros) e textos de Le Corbusier (...) (in Segawa, 2002, pág. 82)

Jovens arquitetos passaram a aplicar os pressupostos modernistas em diversas obras, como Álvaro Vital Brasil e Adhemar Marinho (edifício Esther em São 
Paulo, 1936 - com a integral aplicação dos 5 pontos da arquitetura nova, preconizados por Le Corbusier), ou como os irmãos Marcelo e Milton Roberto que, ao ganharem, em 1936, a concorrência para o projeto da Associação Brasileira de Imprensa e, em 1937, o concurso para o anteprojeto do Aeroporto Santos Dumond, também aplicam em seus projetos os conceitos da moderna arquitetura internacional.

A linguagem moderna internacional, a partir das idéias corbusianas, ganhava, assim, força dentro do cenário brasileiro e era protagonista das discussões sobre os destinos da arquitetura moderna brasileira.

Questões do ideário moderno, como comprometimento social, funcionalidade e clareza dos programas arquitetônicos e o desenvolvimento das tecnologias construtivas, através da racionalização de sua produção, já faziam parte de nossa arquitetura, desde o início da década de 30; entretanto, sua expressão formal, como já foi dito, ainda não traduzia essa modernidade.

A experiência desses jovens arquitetos, a propagação das idéias corbusianas através das publicações nacionais e internacionais, não foram suficientes para fazer do ideário moderno nossa arquitetura oficial, mas, por certo, serviram para dar um rumo para a nova geração que se espalhava pelo Brasil, responsável pela construção de várias obras e pela fundação de novas escolas para o ensino de Arquitetura.

A força dessas idéias, felizmente, também permeara a mente dos intelectuais modernistas brasileiros que assessoravam o ministro Gustavo Capanema, desde o ano de 1934, e, após o resultado do concurso para o projeto da sede do Ministério da Educação e Saúde que premiou os arquitetos Archimedes Memória e Francisque Cuchet com um projeto de linhas marajoaras, o Ministro decidiu somente pagar o prêmio e não executar a idéia vencedora. Para a execução do projeto convidou em

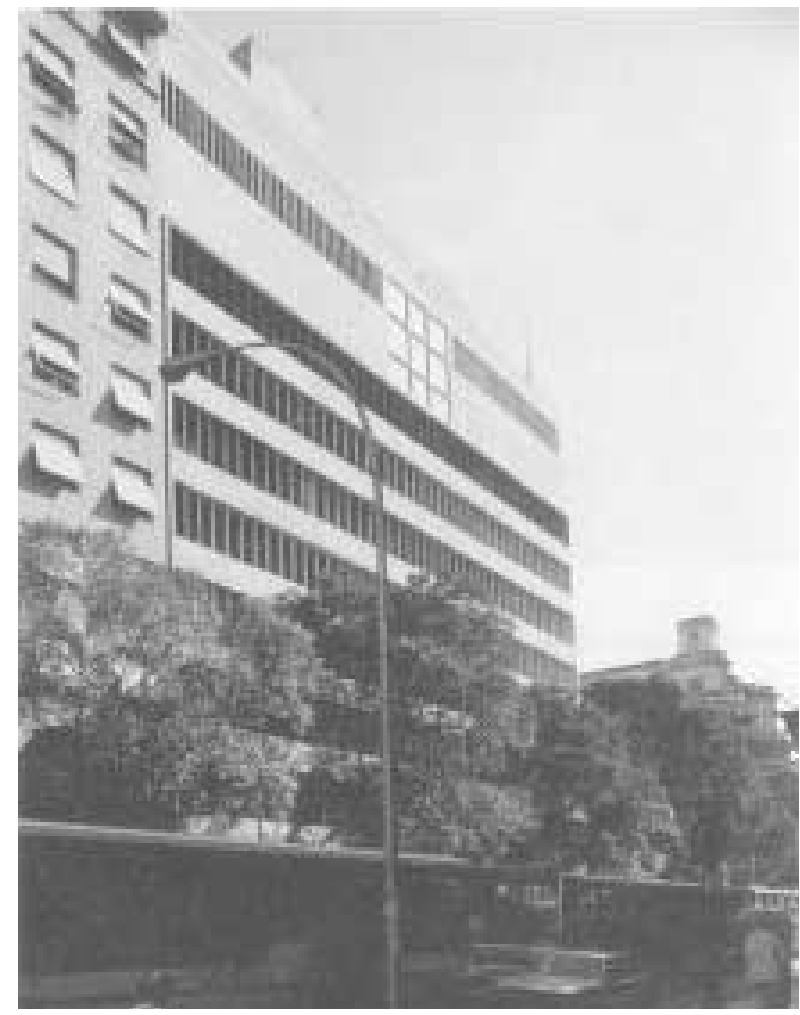

ASSOCIACÃO BRASILEIRA DE IMPRENSA - MARCELO E MILTON ROBERTO 


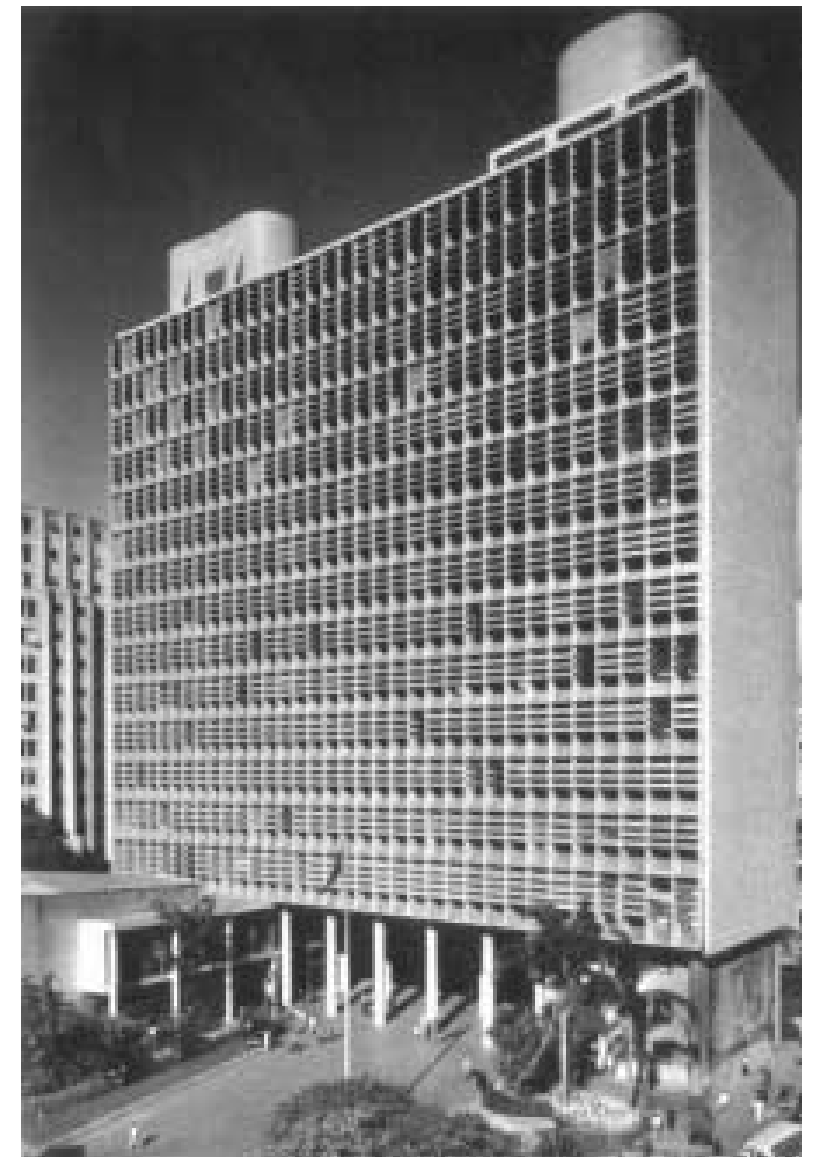

MINISTÉRIO DA EDUCAÇÃO E SAÚDE setembro de 1935, Lúcio Costa para apresentar uma nova proposta, uma vez que nesse momento Lúcio Costa já era bastante considerado pela defesa que fazia de nossa moderna arquitetura e, assim, os auxiliares intelectuais modernistas do Ministro, conhecedores da discussão em curso sobre os rumos de nossa arquitetura, propuseram seu nome.

"Lúcio Costa não tomou o encargo apenas para si. Convocou os arquitetos que haviam apresentado anteprojetos modernos no concurso para formarem uma equipe sob sua chefia: Affonso Eduardo Reidy, Carlos Leão e Jorge Moreira. Ernani Vasconcellos reivindicou um lugar por ser assistente de Moreira e Oscar Niemeyer fez o mesmo, pelo lado de Lúcio Costa. Assim organizado, o grupo passou a desenvolver o novo projeto." (in Segawa, 2002, pág. 89).

Essa corajosa decisão do Ministro Gustavo Capanema a favor da arquitetura moderna brasileira representou uma mudança de rumo dentro de nossa história. $\bigcirc$ novo projeto para a Sede do Ministério, com a assessoria direta do mestre Le Corbusier para uma equipe de jovens arquitetos, já comprometidos com a modernidade de nossa arquitetura, garantiu a liberdade plástica que faltava ao duro racionalismo que praticavam.

O projeto para o edifício do Ministério da Educação e Saúde iniciou-se em 1936 e foi inaugurado somente em 1945. Seus arquitetos, durante esse período, fizeram vários outros projetos, dentro dos ensinamentos adquiridos nessa direta relação com Le Corbusier. $\bigcirc$ projeto mais importante, considerada a dimensão alcançada internacionalmente, foi o projeto para o pavilhão brasileiro da Feira Internacional de Nova York de 1939, feito por Lúcio Costa com a colaboração de Oscar Niemeyer. 
O surpreendente resultado final encantou a crítica internacional no uso das sinuosas curvas propostas pelo jovem arquiteto. $\bigcirc$ sucesso desse pavilhão colocou o Brasil em evidência nas publicações internacionais, conforme descreve Hugo Segawa em seu livro Arquiteturas no Brasil, 1900-1990:

"O sucesso na mídia internacional gerou uma positiva repercussão no Brasil, com a revista Arquitetura e Urbanismo reproduzindo os comentários elogiosos à arquitetura brasileira ("o pavilhão brasileiro tem uma pureza e estilo que fazem a gente perder o fôleg"o, elogiava o magazine Art, ou "Lúcio Costa e Oscar Niemeyer são provas da maturidade intelectual do Brasil", comentava Fortune). Uma mistura de surpresa e ufanismo caracterizavam o noticiário brasileiro do feito em Nova York". (in Segawa, 2002, pág. 93)

Hugo Segawa, a respeito do amadurecimento da arquitetura moderna brasileira, conclui:

"Estava amadurecida, também, a superação do racionalismo mais ortodoxo, com a consciência de uma nova dimensão estética da arquitetura moderna acima da aridez do mero rebatimento da função sobre a forma - lição aprendida no convívio com Le Corbusier em 1936 e algo mais". (in Segawa, 2002, pág. 93)

A contribuição do pavilhão por sua arquitetura e conseqüente propagação dos ensinamentos modernistas nacionais, revelados em uma original síntese brasileira a partir dos cinco pontos preconizados por Le Corbusier, é revelada pela originalidade das curvas que passaram a fazer parte do vocabulário moderno nacional, respaldado a partir do discurso de nosso passado barroco.

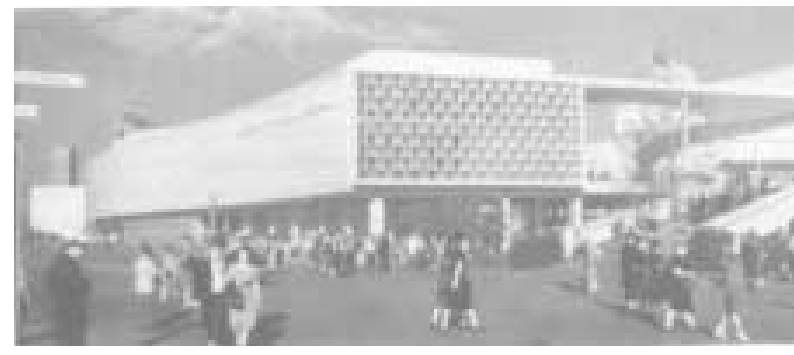

PAVILHÃO BRASILEIRO DA FEIRA INTERNACIONAL DE NOVA YORK DE 1939

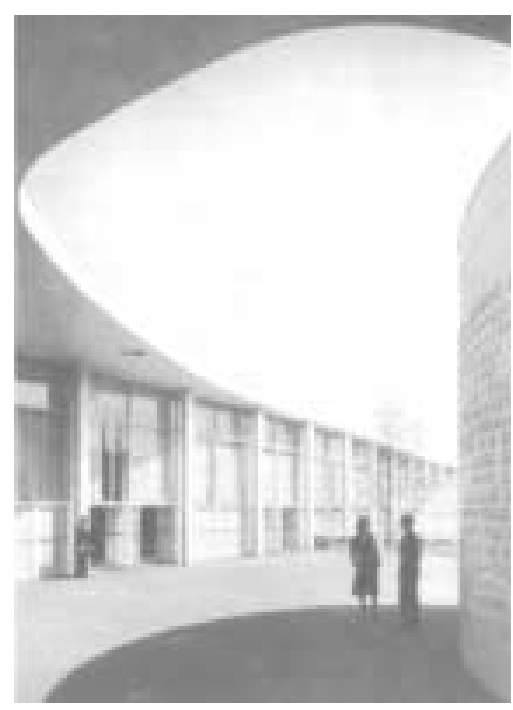

ACESSO SUPERIOR AO PAVILHÃO BRASILEIRO 


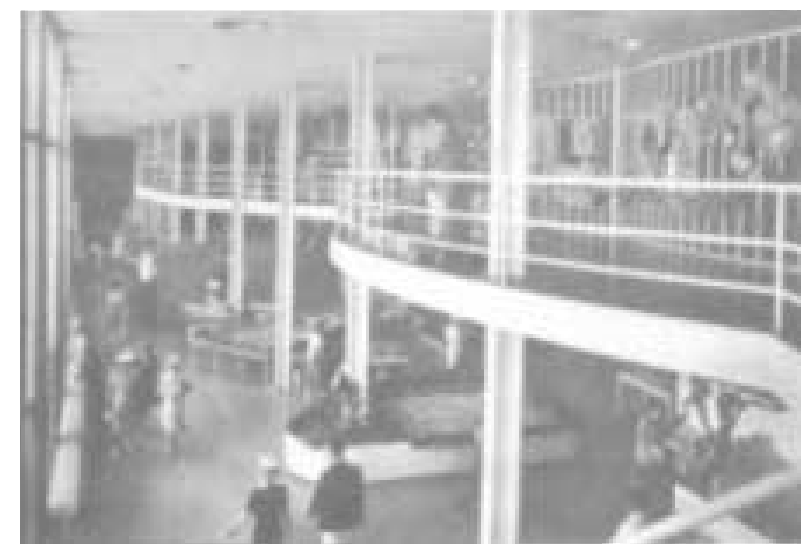

JARDINS INTERNOS DO PAVILHÃO BRASILEIRO

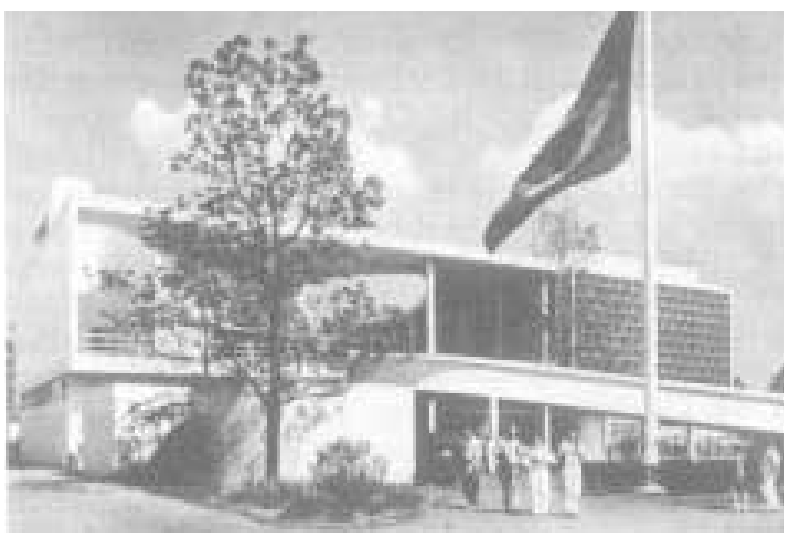

PAVILHÃO BRASILEIRO DA FEIRA INTERNACIONAL DE NOVA YORK DE 1939
Lúcio Costa, a respeito da interação entre as diversas manifestações artísticas que passou, também, a caracterizar a arquitetura moderna brasileira, escreveu:

"Queremos, isso sim, a aplicação rigorosa da técnica moderna e a satisfação precisa das exigências de programa e locais, tudo porém guiado e controlado, no conjunto e nos detalhes pelo desejo constante de fazer obra de arte plástica no sentido mais puro da expressão. Na arquitetura assim compreendida, a pintura e a escultura vêm tomar naturalmente cada qual o seu lugar não como simples ornatos ou elementos decorativos mas como valor artístico autônomo, embora fazendo parte integrante da composição".

\subsubsection{PAPEL DE OSCAR NIEMEYER NA AFIRMAÇÃO DE UM VOCABULÁRIO ARQUITETÔNICO NACIONAL}

Para a compreensão da afirmação do vocabulário que passou a identificar nossa arquitetura moderna nacional, é importante revisitarmos algumas obras emblemáticas da carreira de Oscar Niemeyer e que irão contribuir para a compreensão das composições propostas pelos arquitetos do $2^{\circ}$ Convênio Escolar e de todos os arquitetos comprometidos com um plano de reconstrução nacional e com a concretização de uma identidade cultural brasileira.

Após a revelação do talento de Oscar Niemeyer, aos 32 anos, em sua participação no projeto do Pavilhão de Nova York, o Serviço de Patrimônio Histórico Artístico Nacional (SPHAN) convida-o, em 1939, para um desafio: projetar o Grande Hotel de Ouro Preto, de acordo com a postura que o Serviço de Patrimônio Histórico Artístico Nacional (SPHAN), adotou ao inserir modernidade mesmo em 
situações tão peculiares como o dessa cidade setecentista. $\bigcirc$ projeto resultou, após muita polêmica com os arquitetos neocoloniais, em um trabalho moderno que, mesmo marcando a paisagem com um edifício contemporâneo, conseguia dialogar com seu entorno, através do uso de materiais e detalhes pertinentes à arquitetura colonial dominante.

O projeto do Grande Hotel garantiu o contato de Niemeyer com o governo mineiro e, assim, Juscelino Kubistschek, então prefeito de Belo Horizonte, convida-o para projetar um conjunto de edifícios à beira do lago de Pampulha, então planejado para ser um novo bairro de lazer para a Capital mineira. $\bigcirc$ conjunto encomendado contemplava um cassino, um iate-clube, um restaurante/casa de baile, um hotel e um clube de golfe, além de uma capela (Segawa, 1985). $O$ conjunto final se resumiu ao cassino, ao iate-clube, ao restaurante/casa de baile e à capela, acrescentado de uma casa para o prefeito Juscelino Kubistheck.

Essas obras resultaram em um original vocabulário de formas arquitetônicas, concebidas a partir da arquitetura corbusiana: o telhado asa de borboleta da casa Errazuris, projetado em 1930 por Le Corbusier e Pierre Jeanneret, é aplicado na cobertura da casa projetada para o prefeito Juscelino Kubistheck e na cobertura do cassino; no conjunto dos edifícios, os cinco pontos da arquitetura nova são harmonicamente desenhados e combinados a elementos autóctones como a organicidade das curvas que remetiam ao nosso barroco colonial mineiro.

A capela franciscana, no conjunto construído, destacou-se por sua originalidade, ao aplicar abóbodas e uma casca parabolóide (elementos até então usados somente na arquitetura industrial), resultando em uma harmoniosa volumetria revelada no genial acerto de sua escala.

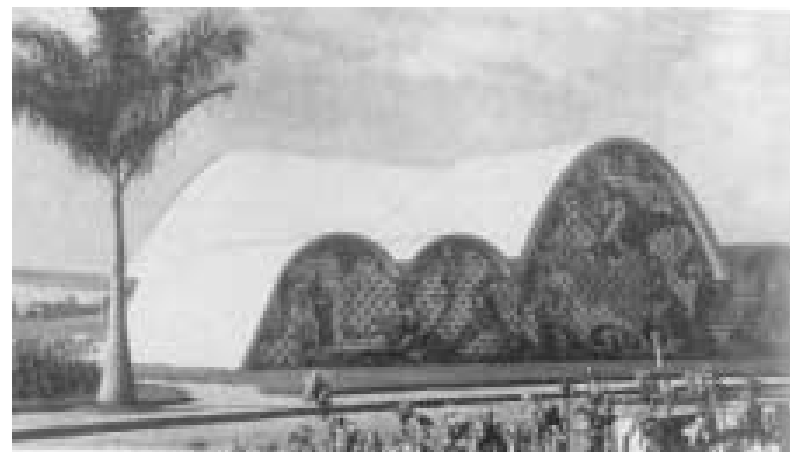

CAPELA SÃO FRANCISCO - OSCAR NIEMEYER MURAL - PORTINARI

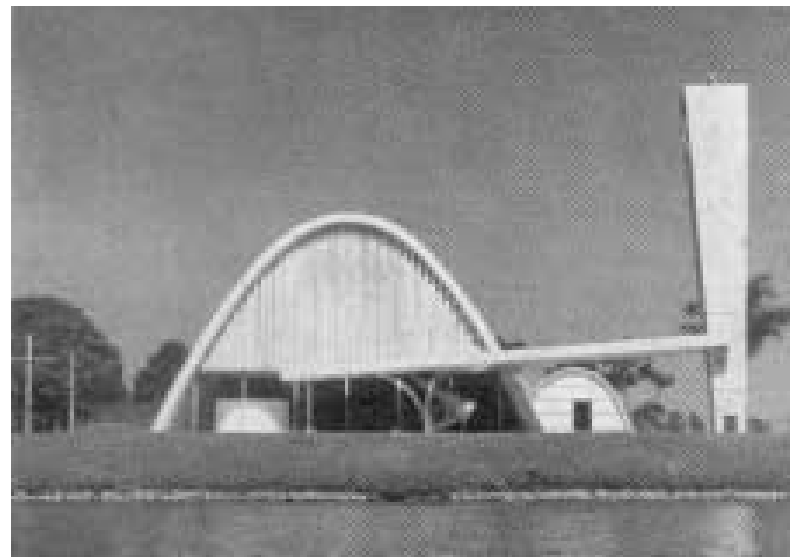

CAPELA SÃO FRANCISCO - OSCAR NIEMEYER VISTA DA LAGOA 


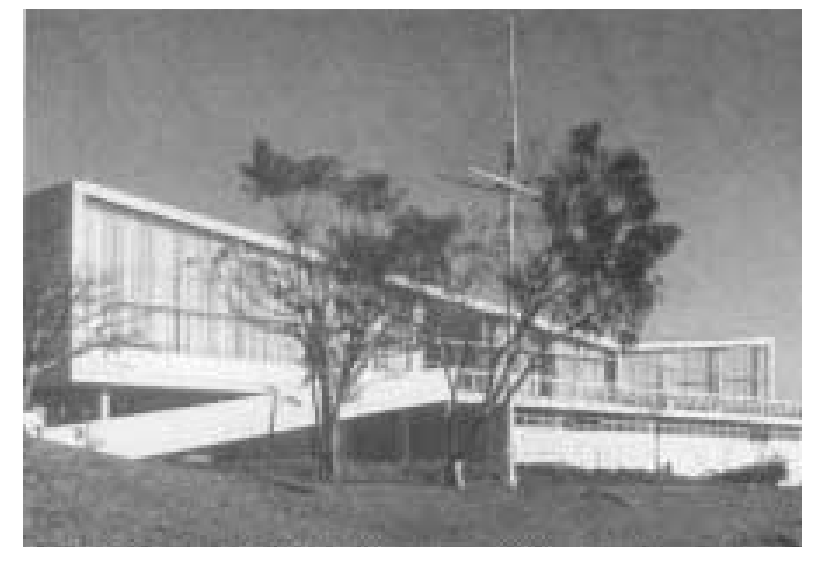

IATE-CLUBE PAMPULHA - OSCAR NIEMEYER

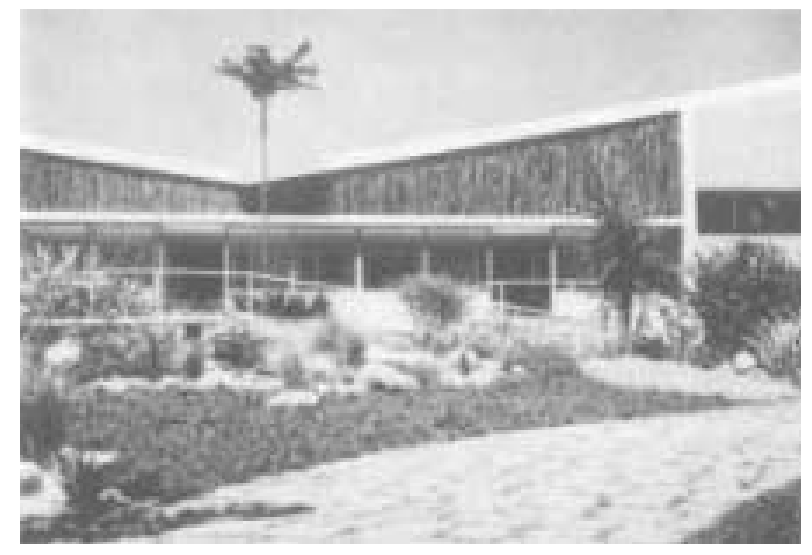

CASA JUSCELINO KUBISTHEK - OSCAR NIEMEYER
Niemeyer consagrou-se, assim, como o arquiteto brasileiro que desenvolveu uma expressão própria para nossa arquitetura. Suas obras foram divulgadas em várias publicações nacionais e internacionais e passaram a ser referência corrente para a produção de obras de arquitetos brasileiros e estrangeiros.

A exposição Brazil Builds, datada de 1943, montada por iniciativa do MoMa de Nova York, e a publicação de seu catálogo de aproximadamente 200 páginas, divulgou para o mundo a história e a originalidade da arquitetura brasileira, e mesmo os brasileiros passaram a ter noção do valor de nossa produção arquitetônica através dessa publicação americana, conforme escreveu Hugo Segawa:

"Brazil Builds resgatava algumas imagens esquecidas e muitas inéditas. Dividida em duas partes - obras antigas, com fotografias da arquitetura colonial e do Império, e obras modernas - Goodwin organizou uma publicação de arquitetura brasileira que os próprios brasileiros desconheciam, como testemunha Mário de Andrade (...) Goodwin, como um observador externo, enfatizava certas conquistas de que a média dos arquitetos brasileiros não se apercebia. Tomando o exemplo do Ministério da Educação e Saúde (então em construção), o norte-americano reconhecia a influência de Le Corbusier (...) mas a ênfase recaiu sobre a produção vinculada aos arquitetos do Rio de Janeiro, com destaque (pelo menos quatro páginas a cada um) para o Ministério da Educação e Saúde (Lúcio Costa e equipe), a sede da Associação Brasileira de Imprensa (Marcelo e Milton Roberto), a Estação de Hidroaviões (Atílio Correia lima e equipe), a casa Cavalcanti, o Grande Hotel de Ouro Preto, a Obra do Berço e o conjunto da Pampulha (Oscar Niemeyer)." (Hugo segawa, 2002. pág. 101) 
A arquitetura nacional, reconhecida pela intelectualidade brasileira e críticos internacionais como representante de nossa identidade cultural, forneceu a todos os arquitetos brasileiros, a partir da segunda metade dos anos 40, forte referência para os projetos a serem idealizados, de acordo com o espírito de nacionalismo e comprometimento com o projeto de desenvolvimento nacional. Na realidade, não era somente um vocabulário que se oferecia, mas todo um discurso e uma coerência ideológica que fez desse período um dos mais profícuos para a história da arquitetura nacional.

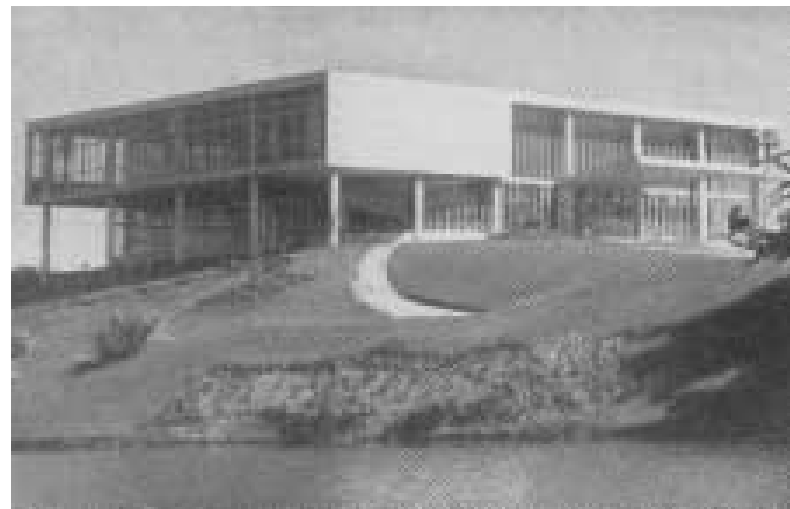

CASSINO - OSCAR NIEMEYER

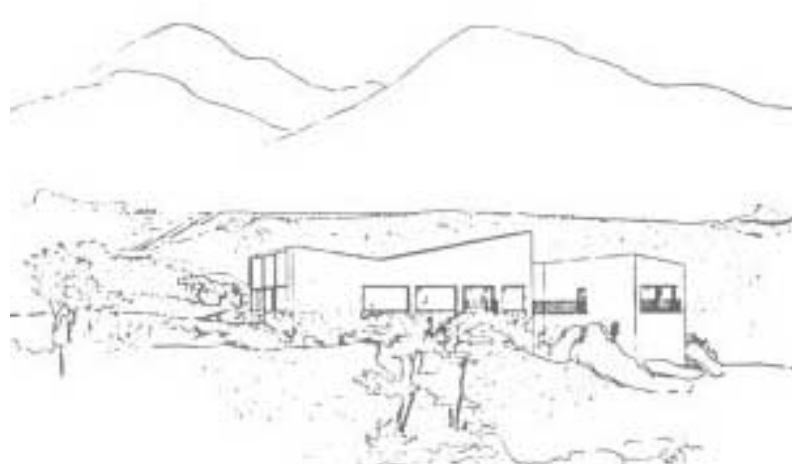

CASA ERRAZURIS - ARQUITETO LE CORBUSIER E PIRRE JEANNERET, 1930

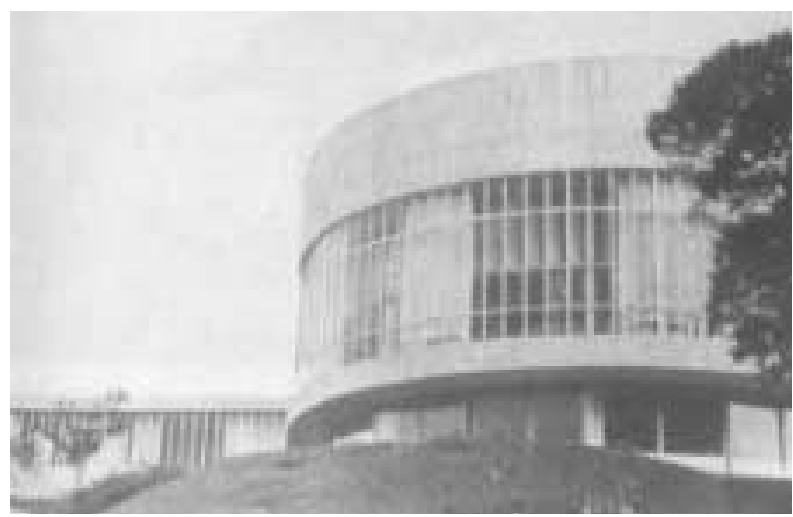

CASA DE BAILE - OSCAR NIEMEYER 
2.3 REFERENCIAIS POSTURAIS: OS EXEMPLOS DE AFFONSO EDUARDO REIDY E LUÍS NUNES 
A autêntica arquitetura moderna, conforme defende Anatole Kopp, revela-se na preocupação social da produção da arquitetura: no atendimento à produção da habitação mínima digna, como desafio para o atendimento da moradia para todos, na produção de edifícios públicos para o atendimento aos programas arquitetônicos para a saúde, para a cultura, para a educação e para o transporte, enfim, no atendimento a todas as melhorias urbanas que a convivência social, nas modernas cidades industriais, pode oferecer.

Esse posicionamento profissional alimentou o sonho de uma sociedade melhor, fruto do labor de muitos arquitetos, entre os quais aqueles que se propuseram a trabalhar no serviço público no Brasil, engajados em um legítimo projeto de desenvolvimento nacional: a ética social moveu o discurso e a ação de vários arquitetos que se identificaram com a escola moderna internacional de arquitetura.

O serviço público para aqueles profissionais comprometidos com o projeto de desenvolvimento nacional, oferecia a oportunidade para que o arquiteto trabalhasse diretamente com a produção de edifícios públicos, uma vez que o Estado não terceirizava, ainda, os projetos arquitetônicos institucionais. Se o escritório do profissional liberal ofereceu ao arquiteto a liberdade formal no desprendimento com o mercado especulativo das construtoras, trabalhar no serviço público ofereceu a possibilidade de se dedicar integralmente a uma causa social.

De acordo com o que vimos nos capítulos anteriores, a modernização dos sistemas de ensino destacou a arquitetura como área técnica estratégica para a implementação da nova escola pública. $\bigcirc$ modo de produção da arquitetura moderna, com sua racionalização, passou a ser a resposta à enorme demanda no serviço público por edifícios escolares. Caberia, portanto, ao arquiteto que ocupasse algum desses 
postos de comando no serviço público a organização de uma linha de produção de projetos, que viesse atender às necessidades que se colocavam, sempre com a solicitação para a produção de um grande número de edifícios, em um curto prazo para sua realização.

A seguir, serão destacados os trabalhos, no serviço público, de dois arquitetos que se assemelharam, por suas posturas projetuais e condução dos projetos dentro de repartições públicas, à equipe de projetos do $2^{\circ}$ Convênio Escolar.

\subsubsection{A INSPIRADORA REFERÊNCIA DE AFFONSO EDUARDO REIDY}

No Rio de Janeiro, Affonso Eduardo Reidy, então recentemente formado pela Escola Nacional de Belas Artes, viu no serviço público a oportunidade de exercer integralmente os ideais preconizados pela arquitetura moderna, podendo colocar-se à margem da construção comercial, comprometida com a especulação imobiliária.

Ao ingressar na Prefeitura do Rio de Janeiro, em 1932, a partir de concurso público para o cargo de arquiteto, trouxe consigo uma significativa bagagem profissional adquirida ao trabalhar com o urbanista Agache no plano de reurbanização da cidade do Distrito Federal, quando teve a oportunidade de conhecer de perto a produção de um projeto público. Agache aplicou uma metodologia para o desenvolvimento de projetos urbanísticos que mais tarde Reidy, ao ocupar a diretoria de urbanismo no Rio de Janeiro, viria a praticar como arquiteto contratado pela prefeitura. 
"Agache (...) introduziu no Brasil uma nova metodologia para se pensar o urbanismo, realizando um plano urbanístico que compatibilizava uma proposta global de ordenamento da cidade, incluindo zoneamento, legislação, saneamento e sistema viário, com um plano de embelezamento e remodelação, preocupado com aspectos estéticos e visando sobretudo à área central, onde se destacava a necessidade de urbanização da Esplanada do Castelo" (in Nabil, 2000)

Outra importante experiência, anterior à sua entrada na Prefeitura, refere-se à sua premiação em concurso público de projetos, ao lado do arquiteto Gerson Pinheiro, para o Albergue da Boa Vontade. Nesse projeto, o arquiteto expressa seus ideais de modernidade ao apresentar, em 1931, uma proposta inovadora, quando despe o edifício de qualquer ornamento e passa a se preocupar, essencialmente, com a funcionalidade de seu programa arquitetônico. $\bigcirc$ que mais chamou a atenção dos jurados, entretanto, foi o tratamento humano dado à questão, revelando essa nobre característica que Reidy imprimiu à sua profissão. Esse projeto, mesmo sendo um dos primeiros de sua carreira, revelou as principais características que iriam acompanhá-lo: o racionalismo e o entendimento de que a função desenha o edifício e de que sua plástica é uma resposta prática à necessidade que o gerou; em sua obra, forma e função devem ser compreendidas como um todo indivisível.

"... o júri, por unanimidade, escolheu o projeto "Ubiratan" por ser aquele que melhor resolvera o lado social do problema. Tratava-se de um trabalho interessante como partido, pois os seus autores, posteriormente verificado serem os talentosos e jovens arquitetos Affonso Eduardo Reidy e Gerson Pompeu Pinheiro, resolveram com muita felicidade o lado social do problema, adotando uma planta em que a

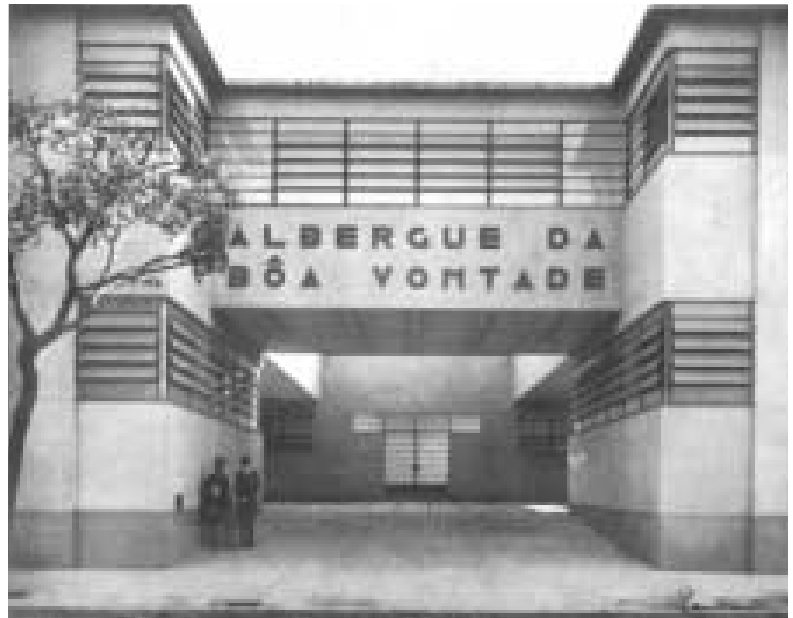

ALBERGUE DA BOA VONTADE - REIDY E GERSON PINHEIRO 


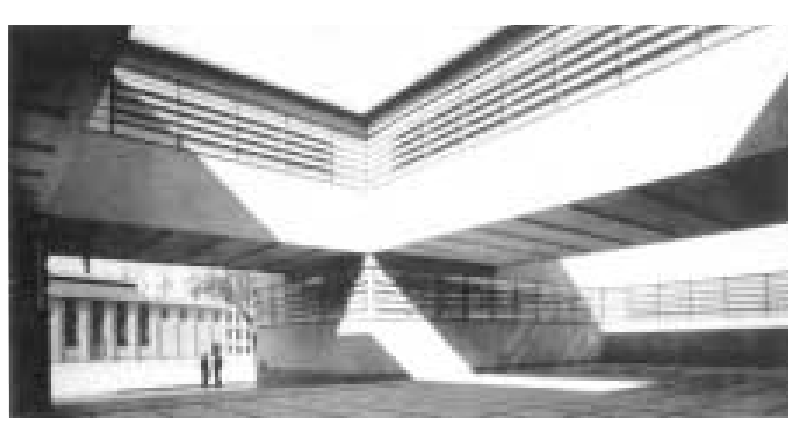

ALBERGUE DA BOA VONTADE entrada é franca para um pátio central coberto em grande parte pelas construções do segundo pavimento, onde o albergado aguarda discretamente, fora do olhar público, o momento de ser levado para subir aos dormitórios. Foi esta interessante solução um dos motivos poderosos para sua classificação, além de terem os premiados resolvido as dependências internas com muita lógica" (in Bonduki, 2000).

$\mathrm{Na}$ prefeitura do Distrito Federal, Reidy ocupou rapidamente cargos de relevância, onde projetou várias obras que, como é característico no serviço público, ficaram arquivadas em gavetas. Sua parceria com Carmem Portinho, então engenheira da Secretaria Geral de Viação, Trabalho e Obras e adepta incondicional dos conceitos racionalistas que orientavam a produção da arquitetura moderna, foi muito frutífera, garantindo a execução de sua obra mais significativa: o Conjunto Pedregulho. Carmem Portinho, expansiva e política no trato dos projetos públicos, complementava a personalidade introspectiva de Reidy e dessa combinação foram garantidas as construções integrais do projeto de Pedregulho, do MAM carioca, e das casas de Jacarepaguá e Itaipava.

É Importante ressaltar, para compreendermos o desafio que sempre foi convencer a aplicação dos conceitos modernos na arquitetura pública, que Carmem Portinho, com a finalidade de divulgar a arquitetura moderna, fundou a Revista da Diretoria de Engenharia da Prefeitura do Distrito Federal (PDF) em 1932, em que foram publicados projetos modernos de relevância, com o intuito de difundir a produção moderna arquitetônica por todo o país. A própria Carmem Portinho redigiu alguns artigos, entre os quais se destacou o artigo difundindo a moderna arquitetura construída na Holanda. Alguns projetos de Reidy, engavetados, significativos pelas soluções apresentadas, foram registrados nessa revista. É também nessa revista que as primeiras escolas modernas do arquiteto Enéas Silva, construídas na gestão de Anísio Teixeira, foram publicadas. 
"Para este grupo de profissionais, Reidy incluído, tratava-se de uma fase heróica, quase de uma luta militante, e a PDF, sigla pela qual a revista passou a ser conhecida, tornou-se uma espécie de trincheira, órgão oficioso deste movimento" (in Bonduki, 2000).

O convite a Reidy para integrar, em 1936, o grupo de arquitetos com a finalidade de desenvolver o moderno projeto para o edifício do Ministério da Educação e Saúde ao lado de Oscar Niemeyer, Lúcio Costa, Carlos Leão e Hernani Vasconcellos e a coordenação de Le Corbusier, representou um ponto de inflexão em sua carreira, no que tange a importância do resultado formal que, até então, era preponderantemente conseqüência do arranjo funcional de seus projetos.

Prova disso, foi uma das versões para o edifício-sede da prefeitura do Rio de Janeiro que, após o contato com Le Corbusier, na equipe do Ministério da Educação e Saúde, apresentou uma solução não só muito bem resolvida quanto às questões funcionais mas também inovadora quanto às questões plásticas.

"A observação dos três projetos realizados por Reidy para o edifício-sede da prefeitura do Distrito Federal atesta o impacto da experiência da equipe do ministério e do contato pessoal com Le Corbusier sobre a linguagem do arquiteto. Na terceira solução, desenvolvida em 1938, Reidy superou a uniformidade e monotonia plástica presente até então em seus projetos, e propôs um novo agenciamento do espaço, com volumes hierarquizados e diferenciados. Além disso, introduziu uma fachada totalmente protegida com brise-soleil, como no projeto do ministério. Abria-se uma nova fase para o trabalho de Reidy" (in Bonduki, 2000). 


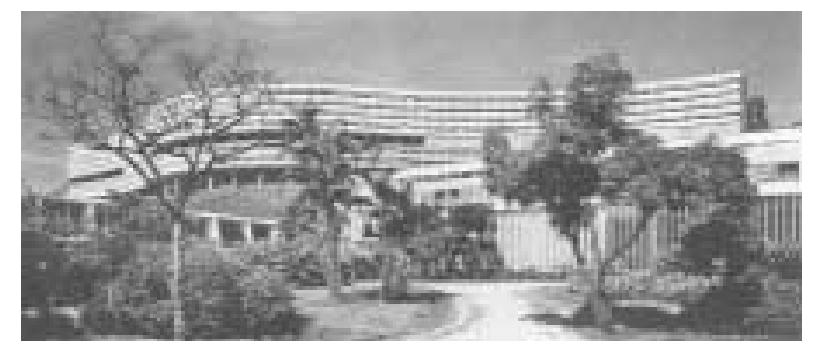

CONJUNTO PEDREGULHO - REIDY
A obra mais emblemática de Reidy, que o projetou para o mundo, foi sem dúvida o Conjunto Pedregulho, quer pelo resultado social alcançado, quer pelo seu surpreendente resultado formal. A expressão plástica típica de nossa produção moderna, cujos primeiros ensaios remetem aos edifícios projetados por Niemeyer, foi muito criticada por estrangeiros, mas essa mesma crítica, diante do resultado social representado pelo Projeto de Pedregulho, abrandou esse julgamento.

A análise do projeto do conjunto de Pedregulho revela o modo "reidyano" de projetar e que, segundo depoimento do arquiteto Roberto Tibau, integrante do $2^{\circ} \mathrm{e}$ $3^{\circ}$ Convênios Escolares serviu de referência para o desenvolvimento dos projetos da equipe no município paulistano.

arquiteto Francisco Bolonha, colaborador constante da equipe de Reidy durante vários anos, descreveu para o livro organizado por Nabil Bonduki, publicado em 2000, o modo "reidyano" de projetar:

"(...) ao reconhecer, de início o sítio escolhido, exigia completo levantamento topográfico, a orientação e o programa a obedecer. Revisitava o local, familiarizando-se com o ambiente, anotando a circulação de pedestres e de veículos, sem, contudo, desprezar a paisagem urbana, que reputava de excepcional importância. Era a preocupação da 'heterogeneidade quanto ao homem'. De posse dos primeiros dados, silencioso, debruçava-se na prancheta a fim de, com obstinação, estudar o problema e esquematizar a solução. Desenhava e refazia até concluir a elaboração de suas idéias. Ansiava pelo perfeito funcionamento do objeto, o que levava a acurado estudo da infra-estrutura, da superestrutura e de todas as instalações. A priori, o essencial era o dimensionamento dos pilares, vigas e lajes, assim como o comportamento das instalações para não ver lesado o conceito do sistema estrutural: atingia-se, então, a homogeneidade quanto à 
'operação do pensamento'. Reidy assessorava-se de excelentes engenheiros especialistas, discutindo a forma mais racional e eficiente para a condução do empreendimento: 'quanto aos movimentos virtuais'.

Estabelecidos, destarte, todos os elementos, Reidy iniciava a fase de anteprojeto, tarefa assaz demorada, porquanto já não era o poeta a arquitetar mas o arquiteto a burilar o objeto de sua paixão. (...) Reidy analisava seu trabalho através de levantamentos, cortes, planos, perspectivas. (...) essa fase do trabalho apresentava-a sempre desenhada, cotada, com indicação das áreas, estrutura e passagens das instalações e, por vezes, do mobiliário e acabamento do edifício.

Aprovado o anteprojeto pelo cliente, Reidy se dispunha à "fase definitiva, cujo desenvolvimento confiava a seus colaboradores. Na conclusão do projeto, Reidy, reunido com seus engenheiros, discutia até a exaustão" (Bolonha, 1985)

○ respeito à paisagem com sua topografia, clima e ventos, a leitura pormenorizada das necessidades a serem atendidas na formatação de criterioso programa arquitetônico, a perfeita correspondência entre a arquitetura e os sistemas construtivos e uma coerente coordenação entre vários e diferentes profissionais, a fim de alcançar o melhor resultado quanto às questões técnicas, fizeram de Reidy referência nacional para os arquitetos. Reidy foi poeta e técnico, arquiteto e humanista em sua carreira ao colocar o ser humano como centro de suas preocupações, através de seu racional entendimento.

"A arquitetura existe em função do homem. Ele é o centro de todas as preocupações e o módulo a que se relacionam todas as medidas. Seu passo determina relações de tempo e de espaço nos locais onde vivemos. Suas necessidades físicas ou espirituais geram os programas a que os arquitetos devem atender..." (Reidy, 1955)

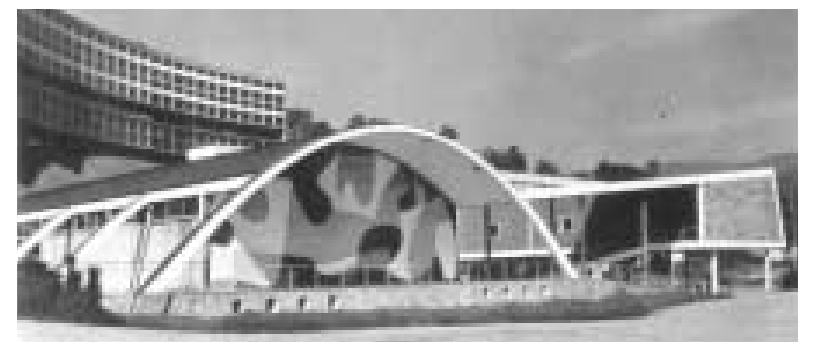

ESCOLA INTEGRANTE DO PROJETO PEDREGULHO - REIDY

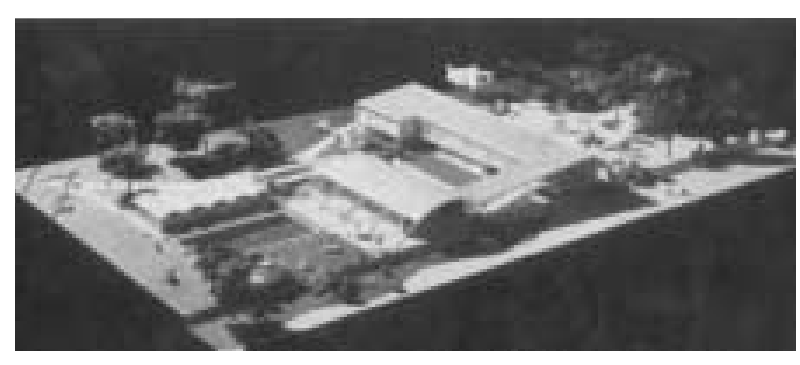

MAQUETE MOSTRA ESCOLA E CONJUNTO ESPORTIVO 


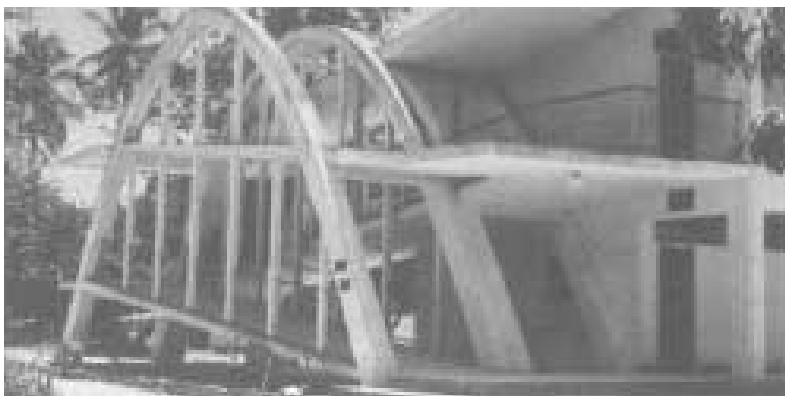

ESCOLA RURAL ALBERTO TORRES, RECIFE, 1935 - LUÍS NUNES

\subsubsection{EXEMPLO DO ARQUITETO LÚIS NUNES NA GESTÃO DA DIRETORIA DE ARQUITETURA E CONSTRUÇÃO DO ESTADO DE PERNAMBUCO}

O arquiteto Luís Nunes, ao assumir, em 1934, a Diretoria de Arquitetura e Construção do estado de Pernambuco, criou um referencial moderno para o desenvolvimento de projetos em uma repartição pública, para a construção de edifícios institucionais naquele Estado e que serviu de exemplo para todo o país. Sua contratação deveu-se à iniciativa do governo de Carlos de Lima Cavalcanti que tinha como objetivo a modernização da máquina administrativa em uma região liderada pela mentalidade oligárquica dos usineiros de cana-de-açúcar.

"É também meu desejo que todos compreendam sem a menor dúvida que estas nossas realizações, cheias do espírito contemporâneo, isentas de qualquer influência individualista, que foram até agora dirigidas por um critério de absoluta honestidade profissional, capaz de conduzir a uma técnica mais evoluída, mais perfeita e, portanto, mais eficiente, ficará durante algum tempo ainda, marcando em Pernambuco uma época em que, como nos centros grandes e civilizados, a arquitetura é uma preocupação administrativa, uma demonstração de cultura e espírito, muita cousa de humano e social" (Luís Nunes, 1935)

arquiteto Luís Nunes, formado pela Escola Nacional de Belas Artes, foi um dos líderes estudantis na greve deflagrada a favor de Lúcio Costa, em sua tentativa de introduzir os ensinamentos da arquitetura moderna naquela instituição. Assim, ao assumir em Recife, o cargo de diretor de um departamento público de arquitetura e 
construção, pôde colocar em prática os ideais modernos que o moviam.

Luís Nunes, apesar das dificuldades em trabalhar em um órgão público coordenou seu grupo de trabalho de forma inovadora ao conseguir integrar as diferentes áreas do conhecimento ligadas à ação do projetar (uma equipe integrada por engenheiros, técnicos e artesãos) e por conseqüência envolvidas com as questões construtivas. Adepto da escola internacional de arquitetura, sobretudo inspirado por Gropius, imprimiu no Recife uma arquitetura racional e contida.

"Sua originalidade tornou-se evidente desde os primeiros projetos, onde demonstrou que a padronização em nada se opunha à expressão arquitetônica e que uma construção podia ser econômica e funcional, oferecendo, ao mesmo tempo, soluções técnicas e formais audaciosas." (in Bruand, 2003)

$\bigcirc$ estado de Pernambuco, bastante atrasado em sua indústria da construção civil, obrigou Luis Nunes a adaptar soluções àquela realidade. Soluções inspiradas em referências da arquitetura internacional como Gropius e Le Corbusier, os quais admirava, só puderam se concretizar com a adequação dessas soluções projetuais à sua realidade, em resposta às questões sociais que visava a atender.

Exemplo de sua criatividade e capacidade de adaptação é a aplicação do cobogó, elemento construtivo largamente usado na arquitetura moderna brasileira e que teve nos edifícios do Recife sua primeira utilização. A aplicação do cobogó foi inventada na administração de Luís Nunes ao inverter-se a posição do bloco já utilizado para construir paredes; quando invertida, sua posição permitia o sombreamento das fachadas sem comprometer a ventilação necessária.

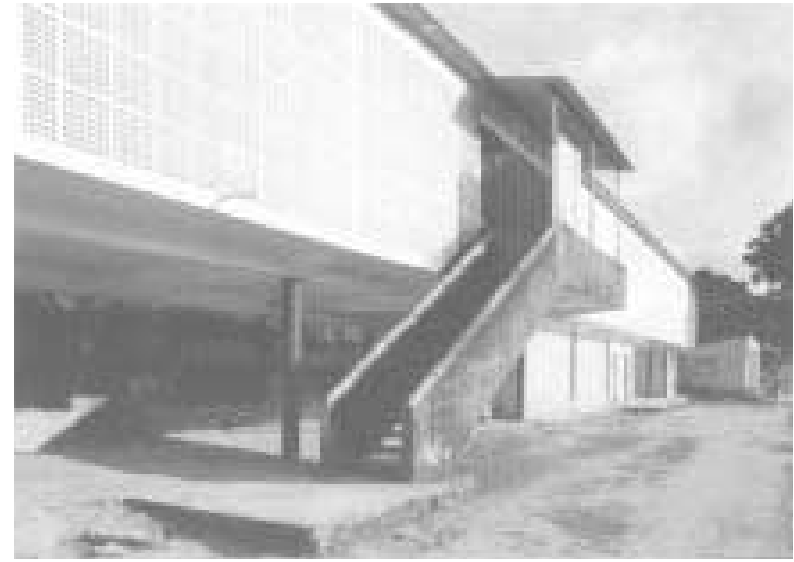

LEPROSÁRIO DE MURUEIRA (PE), 1936 - LUÍS NUNES 


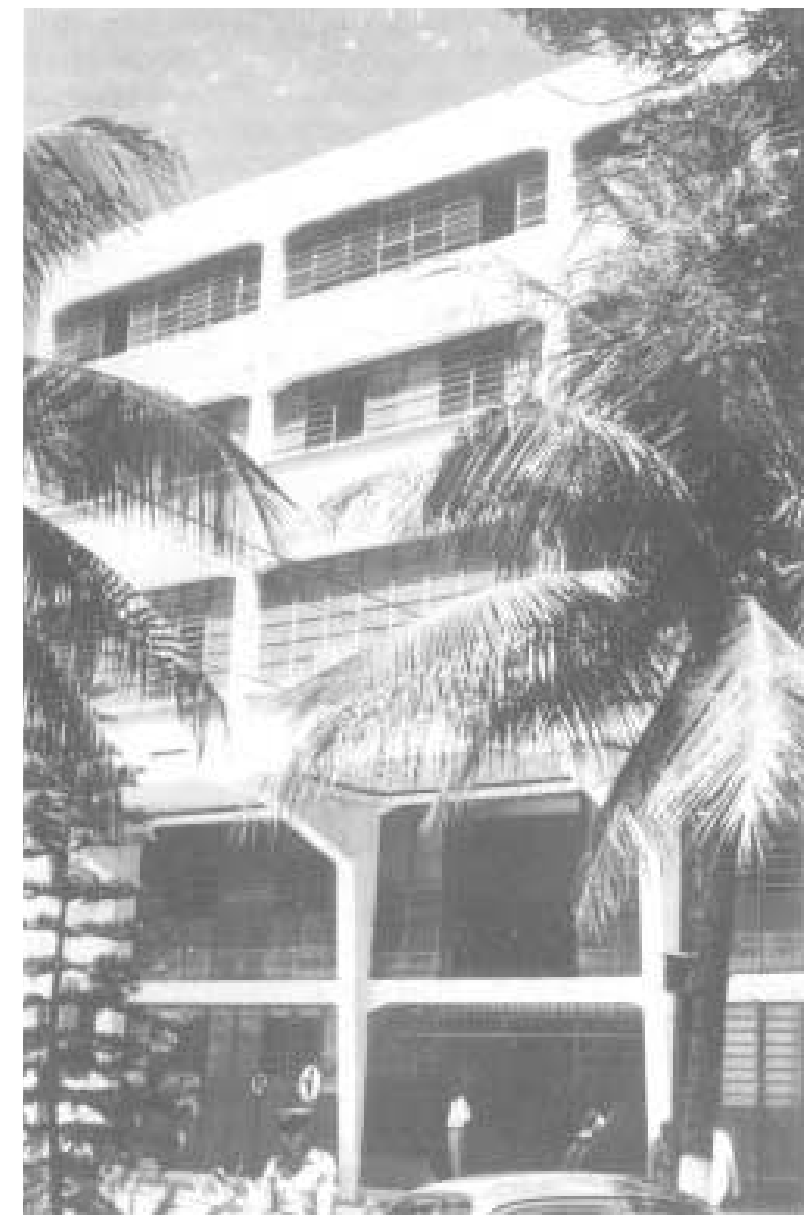

HOSPITAL DA BRIGADA MILITAR, RECIFE, 1935-1937 - LUÍS NUNES
"O movimento do Recife foi um episódio breve, mas não se pode negar sua importância. Extremamente dinâmico, representou significativo esforço de implantação, profunda e racional, da nova arquitetura no Brasil. Perfeitamente homogênea, em conseqüência da personalidade dominante de Luís Nunes, tomou o caminho de uma síntese entre o caráter universal dos princípios básicos e a expressão regional que the podia ser conferida." (in Bruand, 2001)

A racionalidade necessária à produção dos edifícios públicos, aliada ao claro desejo do uso dos materiais "in natura", mostrou-se expressivamente na composição da textura de seus planos e na volumetria dos edifícios e exibiu sua diferença em relação à produção dos arquitetos cariocas. As equipes interdisciplinares, que Luis Nunes constituiu, resultaram na apresentação para o cenário da arquitetura nacional de profissionais como o paisagista Burle Marx e o engenheiro e poeta Joaquim Cardozo.

Podemos concluir, a partir desses dois grandes exemplos que a década de 30 funcionou como uma incubadeira de idéias e de profissionais que iriam construir e inspirar obras de destaque nas décadas de 40 e 50. Assim, podemos ver que a arquitetura moderna, paulatinamente, criou referências brasileiras e passou a ocupar posição central no desenvolvimento da construção de edifícios públicos no Brasil. 
"Com efeito, pela sua nova arquitetura, o Brasil vem participando de um espírito de coragem e de saudável aventura que não anima nenhum outro setor da vida nacional, embora outro não devesse ser o espírito da civilização que se deveria implantar nas amplitudes vazias e promissoras deste continente. O amor ao adquirido e ao privilégio - hoje conquistado repentinamente - um exasperante senso de segurança e um trágico horror ao risco, aliados, à coragem puramente passiva de tudo suportar, fazem de nosso país a mais palpitante contradição. (...) Um pequeno grupo, entretanto, de arquitetos e engenheiros salva o espírito brasileiro, com essa arquitetura moderna que é, antes de tudo, um ato de confiança no país, no gênio de seu povo e no progresso do conhecimento humano.

Todos nós que sonhamos um estado de entusiasmo para a grande aventura de construir nacionalidade, temos nesse movimento da arquitetura brasileira, uma pequena amostra do que poderíamos ser (...)" (in Anísio Teixeira, em "Um presságio de progresso", revista Habitat n. 4, São Paulo, set-dez de 1951) 
3.1 A EQUIPE, 0 LEVANTAMENTO DA SITUAÇ̃̃ DO ENSINO NA CIDADE PAULISTANA E AS CONSEQUENTES POSTURAS INICIAIS ADOTADAS 
"Não à escola-monumento, escola fortim que infunde respeito e que aparece às tenras fantasias das crianças como algo de tenebroso, de áulico e até de inimigo. (...) As escolas do convênio escolar são amplas, horizontais, espaçosas no meio de jardins, são um convite amigável para as nossas crianças...". (in Hélio Duarte, revista Habitat n. 4, São Paulo, set-dez de 1951, pág. 17)

As 52 novas escolas construídas durante a vigência do $2^{\circ}$ Convênio Escolar, objeto de estudo desta dissertação, revela, no seu conjunto, uma unidade no tratamento dos volumes e de sua implantação, que nos chama a atenção. A arquitetura que se revelou nesses novos prédios escolares inaugurou, na construção de edifícios públicos, a linguagem moderna como forma arquitetônica, adotada em grande escala na cidade de São Paulo, em substituição à arquitetura eclética e neoclássica que até então caracterizava os edifícios institucionais.

A linguagem moderna adotada para esses novos edifícios foi conseqüência da hegemonia exercida pela escola moderna carioca na produção arquitetônica, nesse período, em todo o país, conforme colocado no capítulo anterior, e reforçada pela formação dos arquitetos cariocas que fizeram parte da equipe da subcomissão de planejamento do $2^{\circ}$ Convênio Escolar: Hélio de Queiroz Duarte, Roberto GoulartTibau e Eduardo Corona que, graduados pela escola de Belas Artes do Rio de Janeiro, carregaram a herança de Lúcio Costa em sua breve e transformadora passagem por aquela instituição.

No início do $2^{\circ}$ Convênio Escolar, a partir de 1949, juntaram-se ao arquiteto carioca Hélio Duarte, então designado diretor da subcomissão de planejamento, os paulistas: Oswaldo Corrêa Gonçalves, engenheiro-arquiteto e Ernest Robert de Carvalho Mange, engenheiro, ambos formados pela Escola Politécnica da Universidade de São Paulo.

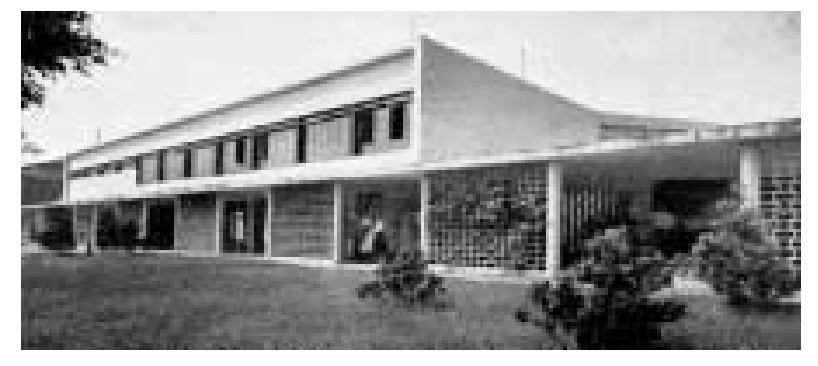

ESCOLA DOMINGOS FAUSTINO SARMIENTO - PROJETO DE ERNEST MANGE 


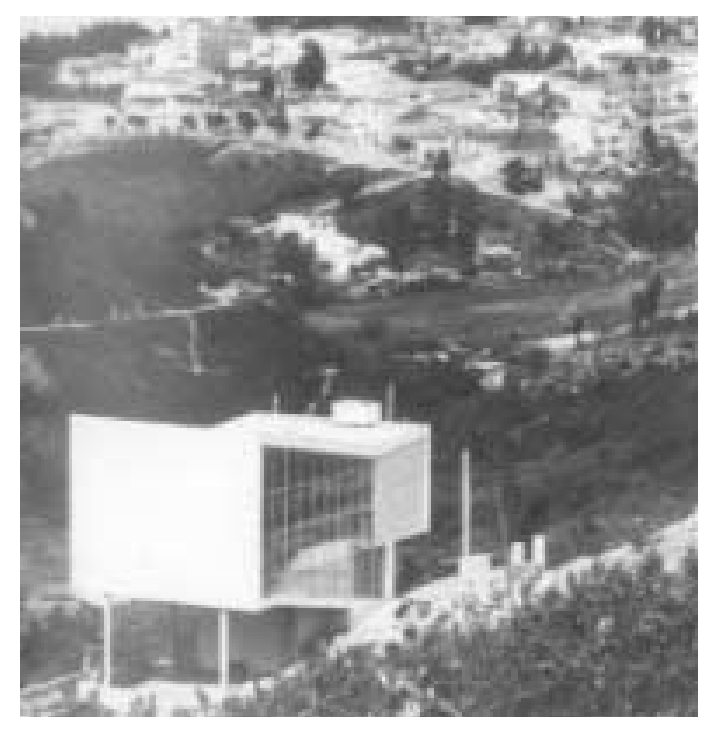

RESIDÊNCIA CZAPSKI (1949) - VILANOVA ARTIGAS

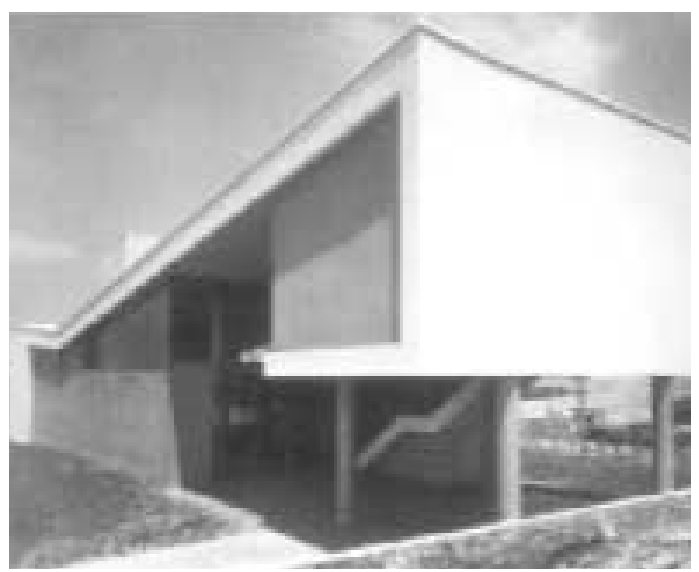

RESIDÊNCIA TAQUES BITENCOURT (1949) - VILANOVA ARTIGAS E CARLOS CASCALDI
É dessa correspondência entre a plástica consagrada por Niemeyer e Reidy, trazida pelos arquitetos cariocas, e a precisão da técnica construtiva, na preocupação que Oswaldo Corrêa Gonçalves e Ernesto Mange carregavam em função de sua formação pela Escola Politécnica, que assistiremos a um ensaio da "escola paulista de arquitetura", revelada anos depois.

Cabe ressaltar que consagrados arquitetos paulistas como Vilanova Artigas e Rino Levi, em meados da década de 40, produziam de acordo com os postulados da escola moderna carioca, "corbuslana" por princípio, aplicando como solução arquitetônica a planta-livre, os volumes prismáticos que se articulam por adição de funções, o pilotis, os brise-soleis e as coberturas "asa de borboleta". 


\subsubsection{OS TRABALHOS INICIAIS DO 20 CONVÊNIO ESCOLAR}

A comissão executiva do $2^{\circ}$ Convênio Escolar, nos três primeiros meses de trabalho, percorreu a cidade com uma pequena equipe, constituída de três engenheiros e um arquiteto, e pôde verificar in loco a calamitosa situação física das escolas existentes ( 108 no total). $\bigcirc$ engenheiro José Amadei, presidente dessa comissão, relatou em conferências públicas algumas das situações encontradas:

"Crianças em porões, em garages, em salas acanhadas comportando normalmente apenas a terça parte dos alunos nela amontoados, salas de prédios novos com a lotação quase dobrada, três, quatro e até seis períodos de aulas, como no G.E. de Vila Guarani, ausência de ar e de luz, e de pátios de recreação, ambientes de ar viciado, muitas vezes uma só instalação sanitária para centenas de crianças de ambos os sexos, água de poços abertos junto às fossas negras, carteiras de caixão de querosene ou de cebola, bancos de tábuas apoiadas sobre pilhas de tijolos, médicos atendendo crianças na rua (G.E. Vila Leopoldina).

Dezenas de milhares de crianças mal nutridas, percorrendo às vezes distâncias enormes, de alguns quilômetros para serem alojadas em pardieiros, necessitando às vezes trazer consigo um vidro com água para matar a sede, alimentadas e vestidas com os minguados recursos da Caixa escolar socorrida com a contribuição de professores particulares." (trecho de palestra do Engenheiro José Amadei, em palestra proferida em outubro de 1949, na Biblioteca Municipal)

Ao conhecimento da situação real, feito em tão pouco tempo, devido à urgência de se colocar em prática a construção das escolas, somaram-se as dificuldades na coleta de dados estatísticos que ajudassem no dimensionamento da demanda de 
estudantes a ser atendida: a comissão trabalhou com os dados de 1940, projetados pelo departamento de estatística da Prefeitura para o ano de 1947. Dessa maneira, através de projeções, pôde-se estimar o crescimento da população em idade escolar e, assim, o número necessário de salas de aula a serem construídas.

A equipe de planejamento, em uma postura claramente científica, traçou, para o início dos trabalhos, apesar das dificuldades, critérios técnicos para o planejamento da distribuição das escolas nos bairros e para o início dos projetos arquitetônicos.

Na leitura dos dados, constatou-se um déficit de 1.200 salas de aula, para uma população de 48.000 crianças. A comissão dimensionou cada classe com 40 alunos para escolas com, no máximo, 12 salas de aula. Assim, seria necessária a construção de 100 novas escolas, no período de 5 anos. Para tanto, foi traçado um plano qüinqüenal, prevendo-se a construção de 20 escolas por ano, com a finalidade de zerar o déficit de salas de aulas até o ano de 1954, em comemoração ao IV Centenário de fundação da cidade de São Paulo. Esse plano qüinqüenal previu também a construção, por ano, de 2 bibliotecas infantis, de 2 dispensários médicos escolares e de I ginásio e incluiu dotações outras destinadas à manutenção de parques infantis e instituições auxiliares de ensino.

Apesar do número considerável de edifícios a serem construídos, essa quantidade estava aquém das reais necessidades, uma vez que o regime de tresdobramento ainda persistia, ou seja, as escolas, depois de inauguradas, atenderiam a três classes no período diurno, por sala de aula, uma situação condenada por Anísio Teixeira, devido ao reduzido número de horas que a criança passaria dentro do ambiente escolar. 
Para o cumprimento do plano qüinqüenal, o engenheiro José Amadei confiou ao arquiteto Hélio Duarte a chefia da subcomissão de planejamento. $\bigcirc$ arquiteto Hélio Duarte havia recém-chegado da Bahia, onde trabalhara com o educador Anísio Teixeira no projeto de implantação do Centro Educacional Carneiro Ribeiro conjunto de escolas-classe e escolas-parque - o mais ambicioso projeto do educador Anísio Teixeira para a inclusão da criança pobre no sistema educacional baiano.

\subsubsection{O EMBASAMENTO PEDAGÓGICO APLICADO ÀS ESCOLAS DO $2^{\circ}$ CONVÊNIO ESCOLAR}

Para a compreensão do embasamento pedagógico aplicado por Hélio Duarte nas escolas do $2^{\circ}$ Convênio Escolar, é de fundamental importância ter conhecimento dos conceitos aprendidos com o educador Anísio Teixeira na concepção do projeto do Centro Educacional Carneiro Ribeiro ao lado do arquiteto Diógenes Rebouças.

O Centro Educacional Carneiro Ribeiro representou a implantação do modelo ideal de escola pública, denominado escola-parque e escola-classe, projeto concebido por Anísio Teixeira na década de 30, como vimos no Capitulo I. Implementar junto ao sistema educacional baiano esse modelo de escola, com o oferecimento de uma estrutura de excelência, através de um completo programa arquitetônico, cuja a finalidade era atender a todas as carências sociais do público infanto-juvenil que morava na pobre periferia da cidade de Salvador, Bahia, rendeu a Anísio premiações concedidas pela Unesco, e o reconhecimento internacional de 
exemplo no atendimento à educação completa e de qualidade. $\bigcirc$ Centro Educacional Carneiro Ribeiro fazia parte de um complexo de escolas-classe e escolas-parque a serem distribuídas estrategicamente pela periferia de Salvador (cada 4 escolas-classe seriam complementadas com I escola parque). Lamentavelmente, a proposta foi reduzida somente a esse conjunto no bairro da Liberdade, que foi finalizado quase 20 anos após o início de suas obras, já na década de 70.

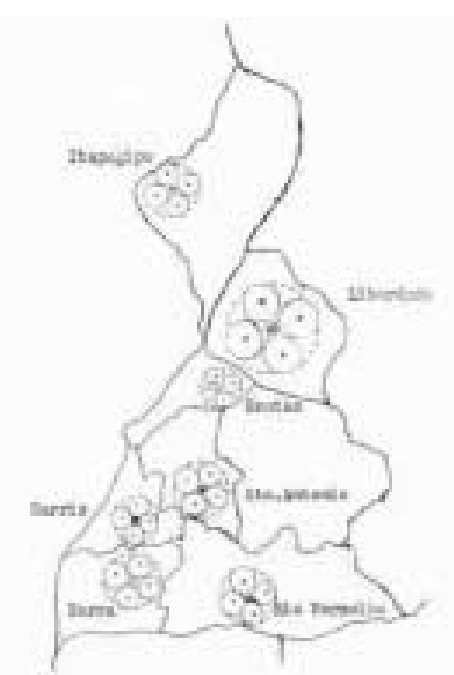

DISTRIBUIÇÃO DOS 7 CONJUNTOS INICIALMENTE PREVISTOS PARA 0 MUNIĆ́PIO DE SALVADOR

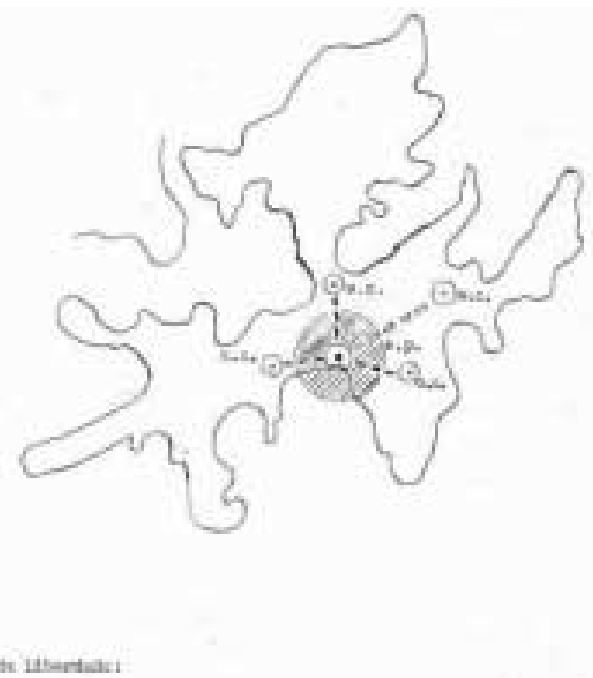

CONJUNTO DA LIBERDADE - ESQUEMA DA IMPLANTAÇÃO DO CONJUNTO ESCOLAS-CLASSE ESCOLAS-PARQUE NA

CONFIGURAÇÃO TOPOGRÁFICA LOCAL 
Para o educador Anísio Teixeira, a educação era uma questão de estratégia nacional a ser enfrentada com os maiores recursos possíveis. Defendia que a qualidade na educação não podia se submeter às questões meramente quantitativas, conforme nos relatou Hélio Duarte, em publicação da Faculdade de Arquitetura e Urbanismo da Universidade de São Paulo (FAUUSP) de 1973:

"Ao invés disso, tudo simplificamos e tudo aceitamos na ilusão de que qualquer cousa é sempre melhor do que nada, o que seria verdade se educação não fosse antes qualidade do que quantidade. Não importa quanta educação, mas qual a educação que está a criança recebendo. Se a simplificação dos meios e a pobreza dos mestres levam a escola a criança a ser inexata, impontual, ineficiente, estúpida, mistificadora, irreal e falsa, está claro que ela não está recebendo, pelo menos, um pouco de educação, mas péssima educação. O que se supunha ser apenas pouco é pouco e péssimo, e somente menos péssimo porque pouco. Se pelo mesmo processo formos com a educação até ao ensino superior, então teremos muito e péssimo."

Inspirado no pensamento de Rui Barbosa, Anísio Teixeira afirmava:

"É custoso e caro porque são custosos e caros os objetivos que visa. Não se pode fazer educação barata - como não se pode fazer guerra barata. Se é a nossa defesa que estamos construindo, o seu preço nunca será demasiado caro, pois não há preço para a sobrevivência." (in Hélio Duarte, apostila FAUUSP, 1973, pág. 26)

A educadora Ester Buffa, sobre a escola de ensino integral e a posição de Anísio Teixeira, escreveu: 
"Anísio Teixeira criticava a escola existente reduzida a objetivos intelectualistas, a um ensino verbalista, a um ensino que classifica (diríamos hoje, um ensino que distingue), destinada às crianças das elites e das camadas médias. Além disso, a presença dos pobres na escola primária impunha à organização escolar problemas que era preciso resolver: irregularidades no desenvolvimento orgânico dos alunos, em suas reações emocionais, nas dificuldades de socialização e no estranhamento da cultura escrita acarretando repetência e evasão. A escola primária só poderia então ser uma escola voltada à educação integral: física, psicológica, moral, intelectual. O edifício escolar exigia, assim, um novo programa arquitetônico, distinto daquele que formara a concepção dos grupos escolares do início do século.

Para Anísio Teixeira, o governo paulista, no intuito de democratizar a escola primária, mas sem os necessários recursos, acabou por simplificá-la ao máximo, reduzindo-a à simples função de alfabetizadora:

É Anísio Teixeira que afirma: a simplificação teve força para congestionar as escolas primárias com os turnos sucessivos de alunos, reduzindo a educação primária não só aos três anos escolares de Washington Luiz, mas aos três anos de meios-dias, ou seja, ano e meio e até, na Grande São Paulo, aos três anos de terço de dia, o que equivale realmente a um ano de vida escolar."

O próprio Anísio Teixeira, no relato abaixo, explica-nos a concepção idealista contida no Centro Educacional Carneiro Ribeiro e sua contraposição ao modelo adotado no Estado de São Paulo naquele momento. Apesar de longa, vale a pena transcrever a citação completa que carrega o idealismo e a fé, características do educador:

"... o corpo de alunos se matriculava nas quatro escolas-classe, onde se organizariam pelas classes e graus convencionais de cada escola e passariam metade do período escolar completo de 9 horas, dividido em 4-1-4 horas. A outra 
metade do tempo decorreria na escola-parque, de organização diversa da escola tradicional, agrupados os alunos, dominantemente pela idade e tipo de aptidões, em grupos já não mais de quarenta, mas de vinte, que deveriam, durante a semana, participar de atividades de trabalho, atividades de educação física, atividades sociais, atividades artísticas e atividades de organização e biblioteca. Cada manhã, metade dos alunos estaria na escola-parque e a outra metade distribuída pelas quatro escolas-classe. Ao meio dia, os alunos da manhã das escolas-classe e se dirigiriam para a escola parque, onde almoçariam, descansariam em atividades de recreio e depois, se distribuiriam, de acordo com o programa, pelas diferentes atividades da escola-parque. E os alunos que haviam passado a manhã na escola-parque iriam, por sua vez, almoçar nas escolas-classe se distribuiriam a seguir pelas suas atividades escolares. Cada aluno pertencia, deste modo, a seu grupo da escola-classe e a outro possível grupo da escolaparque. Como, ao todo, movimentam-se, em cada dia, por vários lugares, primeiro da escola-classe para a escola-parque e, depois, nesta, para o pavilhão de trabalhos, o ginásio de educação física, o pavilhão de atividades sociais, o teatro, a biblioteca e o restaurante, compreende-se que não faltaria complexidade a essa movimentação de dois mil alunos de cada vez para atividades diversas e em locais diferentes. O plano de funcionamento, de horários e de movimentação das crianças, então elaborado, mostrava a perfeita exeqüibilidade do programa e dava ensejo a que se pudesse apreciar os benefícios educativos da estrutura prevista. A organização da escola, pela forma desejada, daria ao aluno a oportunidade de participar, como membro da comunidade escolar, de um conjunto rico e diversificado de experiências, em que sentiria, o estudante da escola-classe, o trabalhador, nas oficinas de atividades industriais, o cidadão, nas atividades sociais, o esportista, no ginásio, o artista, no teatro e nas demais atividades de arte pois todas essas atividades podiam e deviam ser desenvolvidas partindo da experiência atual das crianças para os planejamentos elaborados com sua plena participação e depois executadas por elas próprias. 


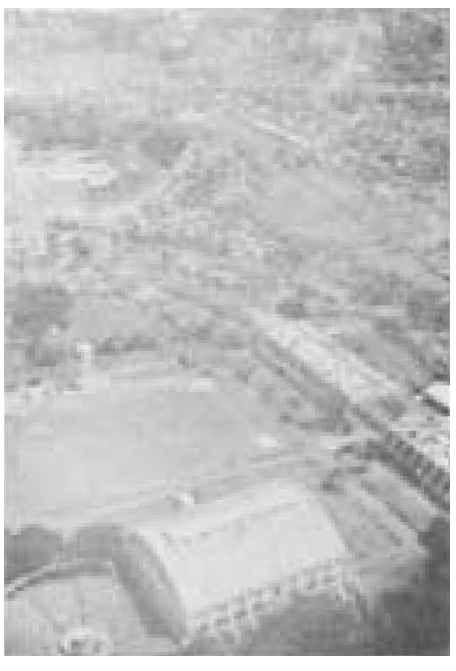

VISTA GERAL DO CENTRO CARNEIRO RIBEIRO

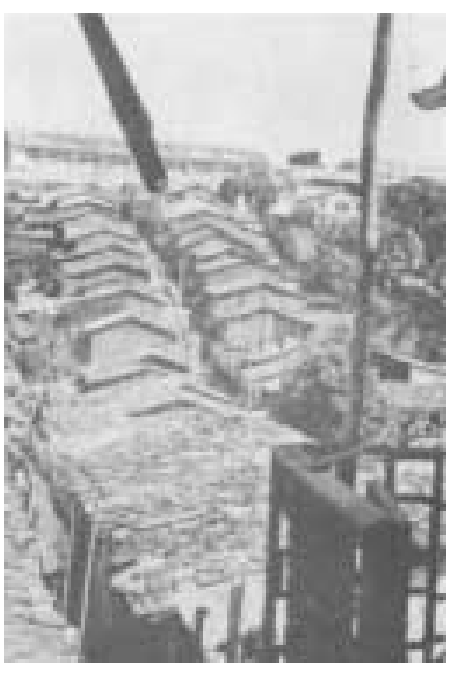

VIZINHANCA POBRE DO CENTRO CARNEIRO RIBEIRO
Seriam experiências educativas, pelas quais as crianças iriam adquirir hábitos de observação, desenvolver a capacidade de imaginar e ter idéias, examinar como poderiam ser executadas e executar o projeto, ganhando, assim, habilitação para a ação inteligente e eficiente em sua vida atual, a projetar-se para o futuro. Se a escola-classe mantinha, em essência, a antiga escola convencional, as condições de trabalho da escola-parque iriam facilitar sobremodo a aplicação dos melhores princípios da educação moderna"

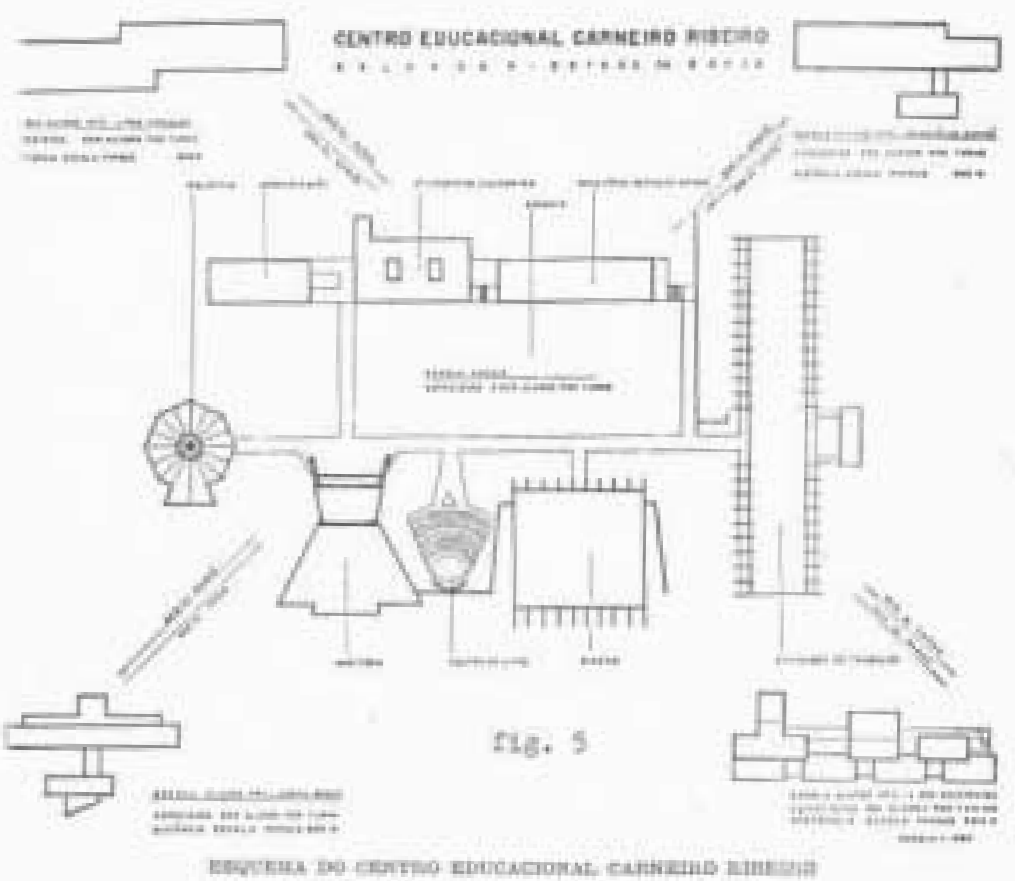

ESQUEMA DO CENTRO EDUCACIONAL CARNEIRO RIBEIRO 
O Centro Educacional Carneiro Ribeiro através da implantação do modelo escola-classe e escola-parque foi, na opinião de Anísio Teixeira, a primeira demonstração do concreto modelo que tinha a oferecer na passagem da escola de poucos para a escola de todos.

A experiência de Salvador - BA, trazida por Hélio Duarte em sua convivência com Anísio Teixeira, reflete a pedagogia aprendida com o educador americano John Dewey que defendia a educação como "processo de reconstrução e reorganização da experiência"; assim, o problema da criança, conhecido e destrinchado, é que dá condições ao educador de buscar soluções para os problemas relacionados à sua educação; é na vida do aluno e na satisfação de suas necessidades que encontraremos matéria-prima para educá-lo.

Enquanto na Bahia as mudanças na concepção das novas escolas passaram por uma revolução no sistema de ensino, em São Paulo as mudanças deram-se no modo de produzir o projeto arquitetônico da escola e no papel que ela que desempenharia nos bairros em que seria implantada.

Hélio Duarte, devido ao fato de ter compartilhado de tão perto as idéias de Anísio Teixeira, e de sua grande experiência na condução de projetos nas áreas da saúde e educação, fez de sua indicação o nome adequado para o desafio proposto para a equipe do $2^{\circ}$ Convênio Escolar em São Paulo.

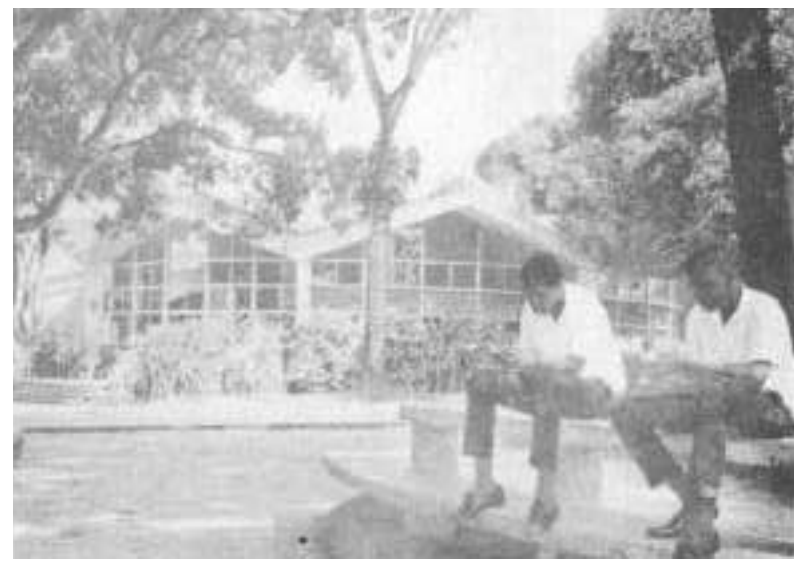

BIBLIOTECA DO CENTRO CARNEIRO RIBEIRO

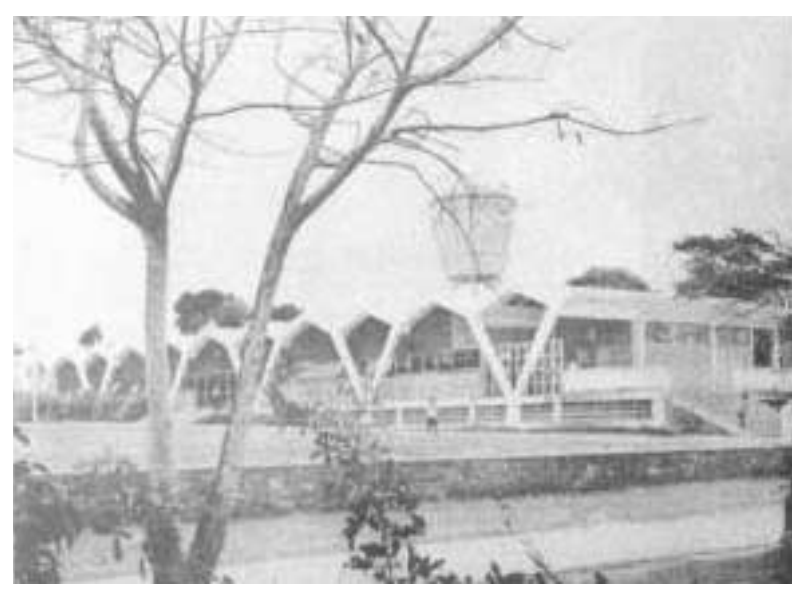

REFEITÓRIO DO CENTRO CARNEIRO RIBEIRO 


\subsubsection{CAUSAS PARA O SUCESSO DO 20 CONVÊNIO ESCOLAR}

O $2^{\circ}$ Convênio Escolar foi antecedido pelo fracasso do $1^{\circ}$ Convênio Escolar, acordado em 1943 e finalizado em 1948, resultando na construção de somente três edifícios escolares, deixando, entretanto, no fundo reservado à educação, um grande volume de dinheiro a ser investido na construção dos edifícios escolares.

As causas que levaram ao resultado positivo deste $2^{\circ}$ Convênio, em relação aos demais, deveram-se à soma de inúmeros fatores, entre os quais, merecem destaque:

- o volume de recursos disponíveis para a específica construção de edifícios destinados, direta ou indiretamente, à educação, de acordo com o preconizado pelo $2{ }^{\circ}$ Convênio, no qual a contribuição Municipal dobrou de 10\% para 20\% de acordo com o estabelecido pela Constituição Federal de 1946;

- o parque industrial paulista cresceu excepcionalmente ano a ano gerando uma receita generosa para aplicação na construção de novos edifícios escolares;

- a formação de uma Comissão Executiva, em 1948, destinada exclusivamente à viabilização do plano para a construção de 100 escolas e equipamentos de apoio ao ensino primário;

- o binômio arquitetura moderna e projetos pedagógicos escolanovistas estarem caminhando juntos, desde a década de 30, a favor da renovação da escola pública;

- o reconhecimento de que a arquitetura moderna, fruto do pensamento técnicocientífico, traria resultados econômicos na produção seriada de edifícios públicos voltados para a educação, sem abrir mão de uma genuína expressão da cultura nacional, reconhecida também no cenário internacional; 
- a disponibilidade de um quadro de jovens arquitetos preparados para a produção de projetos modernos, e formados pela Escola Nacional de Belas Artes;

- o serviço público, naquele momento, representou para alguns jovens arquitetos o ambiente ideal para a produção da legítima arquitetura moderna, longe das amarras do especulativo mercado imobiliário, já enraizado nas grandes cidades brasileiras;

- a arquitetura moderna carioca era hegemônica no quadro da produção nacional de arquitetura;

- os bairros adquiriram importância estratégica nos planos dos políticos que passaram a enfrentar os pleitos eleitorais para a permanência no poder;

- o grande e crescente déficit de salas de aula, que aumentava exponencialmente ano a ano, exigindo medidas efetivas das autoridades municipais.

Dessa maneira, a equipe de arquitetura liderada por Hélio Duarte e respaldada pelo apoio incondicional do Presidente da Comissão Executiva, engenheiro José Amadei, pôde apresentar com liberdade as propostas escolanovistas inspiradas em Anísio Teixeira para a composição do programa arquitetônico das escolas e, ao mesmo tempo, garantir a linguagem moderna carioca como expressão, para a arquitetura dos novos edifícios escolares.

É fato, também, que os arquitetos modernos gozavam de grande prestígio junto à burguesia industrial e a classe política, uma vez que a arquitetura moderna, pelo significado que passou a ter naquele momento, legitimava de certa maneira seus planos. Para confirmar esse fato, como visto no capítulo 2, temos nesse mesmo período, Oscar Niemeyer, o mais destacado arquiteto da escola moderna carioca, sendo contratado para projetar os edifícios do Parque do Ibirapuera. A burguesia 
industrial paulistana visava a colocar a cidade de São Paulo no circuito cultural nacional e internacional, de acordo com a posição econômica que já ocupava no cenário mundial daquela década.

\subsubsection{ARQUITETURA ESCOLAR EXPERIMENTAL: A CONSTRUCÃ̃ DE CONCEITOS A PARTIR DA ESCALA DA CRIANÇA}

Hélio Duarte em artigo para a Revista Habitat n. 04, sobre o início dos trabalhos da Comissão Executiva, descreveu as preocupações e posturas iniciais da equipe de projetos para a construção dos novos grupos escolares:

"A nós arquitetos e engenheiros ocorreu-nos perguntar? - Para que espécies de ensino deveriam ser feitos os grupos? Quais os rumos da educação? Qual o meio subjetivo adequado a uma melhor integração da psique infantil? Qual o ambiente físico mais propício? Essas nossas perguntas ficaram sem respostas. Procuramos então contornar o problema imaginando um novo tipo de grupo que mais se aproximasse da mentalidade infantil. É possível que um ambiente modernizado imponha, de certo modo, por si mesmo, uma reforma de Ensino. Resta-nos, ao menos, essa esperança. Indagações sobre o programa escolar, sobre a vida ativa de um grupo, pesquisas sobre os novos métodos de ensino, consultas às boas fontes da psicologia infantil, tudo foi sumariamente passado em revista, comentado e discutido. Trabalho de monta apenas iniciado e que figura como condição indispensável e como complemento determinativo para um bom projeto." 
Para Hélio Duarte e equipe, foi destinado às crianças, o modelo de escola a ser criado: para suas medidas, suas sensações e sua psique. Entretanto, os arquitetos só poderiam atender a essa prioridade, à medida que obtivessem dados e respostas para as questões educacionais pertinentes à esse universo, pois acreditava-se, como já vimos, que o espaço físico a ser projetado era um dos meios para que o projeto pedagógico escolanovista se realizasse.

Hélio Duarte lamentou que o tempo fosse tão curto para atender à construção de número tão grande de escolas e que sua equipe não pudesse ter um conhecimento mais aprofundado das questões educacionais que já eram discutidas pelos educadores e filósofos da educação no Brasil, desde a década de 30.

\section{Desenho}

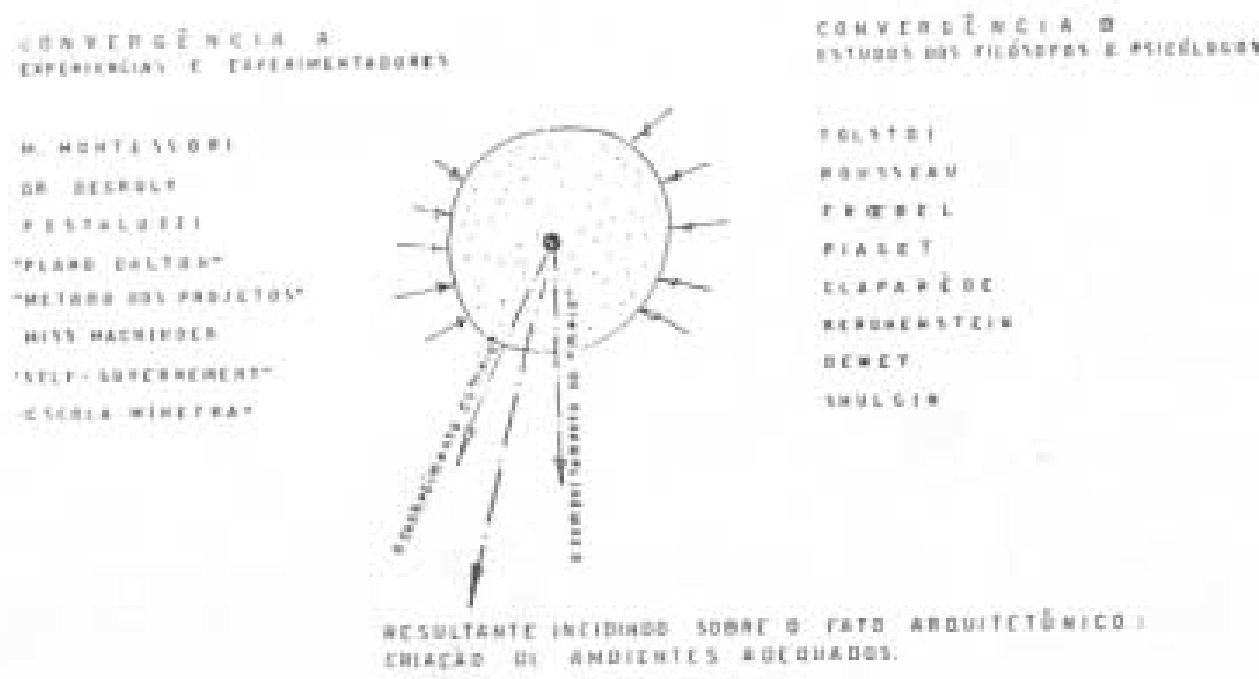

con

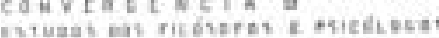


Reuniões com delegados de ensino e autoridades ligadas à educação municipal foram feitas à exaustão, não se chegando, entretanto, aos resultados esperados; mas mesmo diante dessa dificuldade, a comissão do convênio chegou às primeiras conceituações que nortearam o início dos projetos arquitetônicos:

- é para a criança que a escola deverá ser projetada;

- a primeira questão a ser resolvida passa pela quantidade de edifícios a serem construídos; assim, as definições de projeto devem passar, necessariamente, pelas questões econômicas;

- a natureza deverá fazer parte do desenho das escolas, de maneira a integrar-se aos ambientes construídos para a criança;

- os funcionários da escola também deverão ser considerados no dimensionamento dos espaços com "conforto simples, mas efetivo";

- o mobiliário deverá ser padronizado e projetado, considerando-se as diferentes medidas das crianças em suas várias faixas etárias;

— os espaços deverão privilegiar a flexibilidade de uso, de acordo com a dinâmica de transformações pelas quais passam os projetos pedagógicos; não devem ser "recintos catalogados e fechados, como peças em um museu de cera";

— os espaços deverão ser desenhados, considerando-se a mobilidade infantil, seus passos, acessos verticais, distâncias a serem percorridas, correrias e integração entre os espaços livres e construídos;

- domínio das técnicas e teorias relativas ao conforto auditivo, visual, térmico para o adequado desenho dos ambientes a serem construídos;

- transição entre o espaço público e o espaço do edifício escolar, de modo a introduzir os usuários na escala da criança. 
Essas primeiras conceituações não eram fechadas, uma vez que a arquitetura escolar, devido ao seu comprometimento com o projeto pedagógico escolanovista, estaria sempre em constante revisão, e assim como área específica da arquitetura seria experimental, por princípio.

O engenheiro Ernest Robert de Carvalho Mange, membro da equipe de Hélio Duarte, conclui, acerca do experimentalismo da arquitetura escolar:

1. "Se quase todas as obras de arquitetura são hoje experimentais, esse caráter acentua-se extraordinariamente em matéria de arquitetura escolar."

2. "Considerando-se a importância e a complexidade do programa educacional só um trabalho de equipe (arquitetos com a colaboração de professores, psicólogos, médicos etc), de pesquisa e experimentação poderá produzir protótipos de real valor."

3. "O mundo civilizado procura intensamente soluções para seus problemas educacionais, pesquisa sua arquitetura escolar. No Brasil, o problema se põe em termos dramáticos, pois, quantitativamente, pouco temos com relação ao que deveríamos ter: praticamente está quase tudo por fazer. É preciso não perder de vista que devemos fazer muito e bem; resolver o problema em números e em qualidade. Impõe-se, assim, ao lado das básicas providências que permitam obter os recursos necessários, a formação das equipes de trabalho, preparadas para a função. Essa é uma tarefa de arquitetos." (in revista Acrópole n 197, março de 1955) 


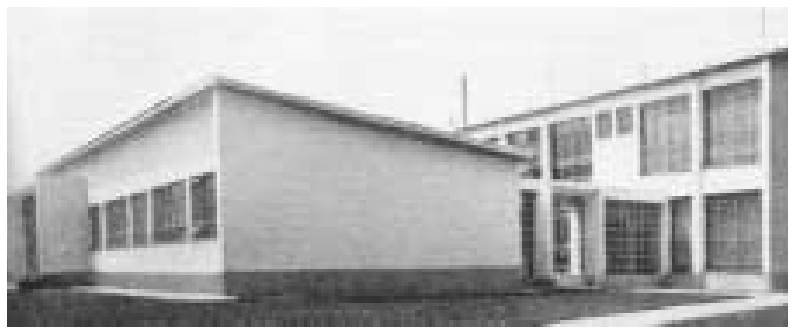

ESCOLA PEDRO VOSS - OS PROJETOS DE ERNEST MANGE, ATRAVÉS DE PÁtIOS INTERNOS, POSSIBILITARAM ILUMINAÇ̃̃O BILATERAL NAS SALAS DE AULA

\subsubsection{RECOMENDAÇ̃̃ES TÉCNICAS ADOTADAS PELA EQUIPE DE HÉLIO DUARTE}

A subcomissão de planejamento do $2^{\circ}$ Convênio Escolar em seus "Estudos Técnicos sobre Grupos Escolares", recomendava para aplicação nos projetos:

- Iluminação: a sala de aula deve estar voltada para a face norte, a fim de obter o máximo de iluminância natural; essa face oferece, também, maior quantidade de calor no inverno, e o fato de seu oposto ser a face sul, promove ventilação cruzada, uma vez que os ventos dominantes na cidade são os que incidem a partir do sudeste e sul. A iluminação bilateral é recomendada pelo convênio.

- Ventilação: a ventilação cruzada é recomendada, de modo que haja uma renovação de ar na sala de aula na ordem de 5 trocas do volume total do ar a cada I hora. $O$ caixilho basculante, com aberturas na parte inferior para tomada de ar frio e saída de ar quente a partir de seu basculante superior, é também recomendado pelo convênio.

- Circulação vertical: a escada, em função da extensão do passo da criança, deve ter seu espelho e pisada do degrau revistos de $17 \mathrm{~cm}$, para $12,5 \mathrm{~cm}$ e de $30 \mathrm{~cm}$ para $20 \mathrm{~cm}$, respectivamente, considerando que a criança tem passo de $45 \mathrm{~cm}$ contra os $63 \mathrm{~cm}$, em média, de um adulto.

- Dimensões e escala dos ambientes voltados à percepção infantil: o engenheiro Ernest Robert de Carvalho Mange, a respeito da dificuldade de arquitetos adultos projetarem para a escala da criança, escreveu artigo na revista Acrópole $n^{\circ} 194$ de março de 1955: 
"Nisso reside talvez uma das maiores dificuldades da arquitetura escolar, particularmente porque o arquiteto como adulto terá de realizar grande esforço de acomodação. Como exemplo típico do fator arquitetônico de enorme valor na ambientação psicológica podemos citar a escala. A escala dos elementos e do todo da obra deve subordinar-se a este imperativo. Advém daí, dada a extensão dos programas, uma dificuldade séria. Devemos sempre ter em mente que a avaliação sensivel dos volumes será feita pela criança em função de seu próprio volume. Assim para uma criança normal de 1,20 m de altura, com relação a um adulto médio, as sensações dos volumes estarão na relação de 3 para l.

$$
\text { hc/ha }=1,20 / 1,70-0,7 \quad \quad V c / V a-(0,7) a o \text { cubo }=1 / 3
$$

$h c=$ altura da criança; $h a=$ altura do adulto; e Vc = volume da criança; $V_{a}=$ volume do adulto

Essas considerações levam à diminuição das alturas dos compartimentos e a tratamentos especiais de suas superfícies, visando a harmonizar as dimensões funcionais dos volumes à escala da criança. Exagerando-se um pouco: principia a estar bem para a criança quando, começa a ficar ruim para o professor..."

- Cores: como em todos os outros quesitos técnicos, a equipe de projetos procurou atender às questões cromáticas das escolas, pesquisando várias e diferentes teorias, com a finalidade de aplicar o que de melhor na área de arquitetura escolar pudesse atender ao conforto da criança e à melhoria de seu desempenho pedagógico. Para o uso de cores é recomendado:

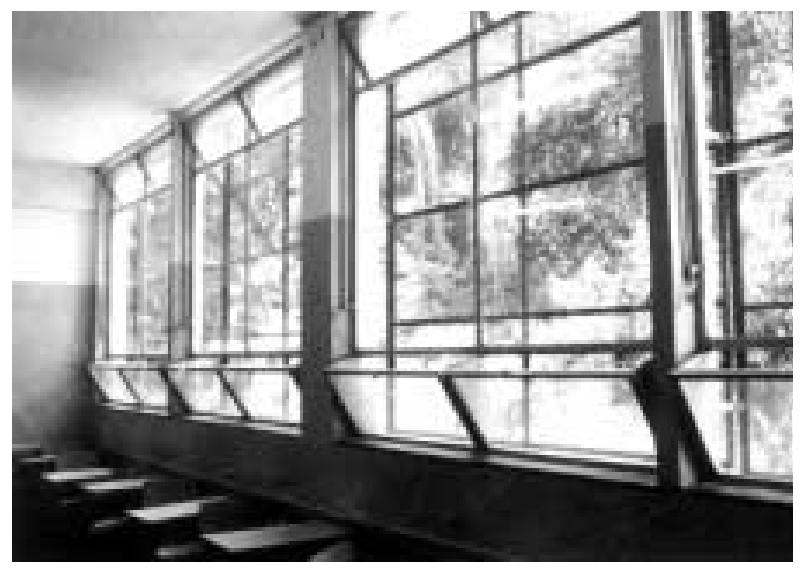

ESCOLA BRASÍLIO MACHADO DA VILA MADALENA - ARQUITETO HÉLIO DUARTE 
"Em nossas salas poderíamos concluir optando pelo forro caiado de branco, por ser o cal fosco e o branco o melhor refletor de luz.

A parede norte poderia ser verde clara ou de cor neutra. Preferivelmente 0 branco nos fornece boa reflexão de luz.

A parede sul deve também ser branca para refletir a luz que vem do norte, principalmente nos dias encobertos.

A parede dos fundos que não é vista pelo aluno deve ainda ser branca pela mesma razão.

A porta deve ser cinza ou outra cor neutra.

Assim toda a atenção do aluno recairá na parede da frente a qual deve ser cor de laranja sem mistura.

O quadro tradicionalmente negro deve ser verde escuro pois esta cor absorve em parte a luz sendo auxiliada pela posição do quadro...

O giz usado deveria também, para atrair a atenção da criança, ser amarelo pois está provado e adotado nas estradas de rodagem do mundo inteiro, que 0 amarelo sobre o preto é mais visível que o preto sobre o branco.

Como iremos usar verde escuro, o amarelo deve ainda ser mais indicado que 0 branco e com a vantagem de ser a cor que mais estimula a criança no elemento que mais deve chamar sua atenção que é o giz.

A cor estimulante disposta em menor área e justamente onde se espera a atenção do aluno deve ser mais racional do que na sala toda, onde pode ser elemento de indisciplina."

A equipe de projetos do $2^{\circ}$ Convênio Escolar notabilizou-se por fazer uso da pesquisa a fim de que seus resultados fossem produtos da organização de informações científicas. $\bigcirc$ apuro nas definições técnicas resultou em velocidade e uniformidade de produção, e a padronização foi entendida como algo mais 
complexo, não como mera repetição, mas como escolha do que é mais adequado às várias situações que levam à sua repetição.

A produção da equipe confirmou uma uniformidade que colocou em dúvida a autoria de muitos projetos, o que denota que a autoria ficou em segundo plano, em relação à importância das questões que os unia como equipe.

Hélio Duarte, sobre o papel que cabia à arquitetura, nos diz:

"Como bem podem ter verificado, existe em todas as unidades apresentadas a mesma ordem de idéias - porque arquitetura é isto mesmo ordem, questão de organização - organizar um conjunto de elementos dispô-lo em ordem, a melhor - uns em relação aos outros, distribuir as respectivas dimensões, assegurar, com igual esforço, a ligação e a coexistência que deve existir entre eles a fim de que o conjunto seja, verdadeiramente, uma unidade congruente.

É neste sentido que arquitetura pode ser considerada síntese, não consistindo somente, em adicionar e justapor elementos separados, mas ligá-los entrosando-os em função determinada e capaz de constituir uma unidade orgânica efetiva." 
3.2 RACIONALIZAÇ̃̃O NA PRODUÇ̃̃O SERIADA DE PROJETOS ECONÔMICOS, IMPLANTAÇÃO E PROGRAMA ARQUITETÔNICO DOS NOVOS EDIFÍCIOS PARA A EDUCAÇÃO: PRAÇAS DE SERVIÇOS PÚBLICOS NOS BAIRROS PAULISTANOS 
atendimento ao plano qüinqüenal para a construção de 20 escolas por ano orientou a dinâmica dos trabalhos da Subdivisão de Planejamento da Comissão Executiva. Para tanto, organizou-se uma linha de produção de projetos para edifícios escolares sem repeti-los como edifícios padrão e a padronização aplicou-se no uso de componentes construtivos e na definição de três blocos funcionais que, articulados em função das diferentes implantações, respondiam às variáveis dos terrenos escolhidos ou disponibilizados para suas construções.

A necessária produção em série e a racionalização da produção dos projetos, propostas por Hélio Duarte, partiram, em linhas gerais, dos seguintes pressupostos, conforme nos revelou a análise dos 52 projetos produzidos pelo $2^{\circ}$ Convênio Escolar:

- compartimentação das escolas em três blocos funcionais: bloco de ensino, bloco administrativo e bloco de recreação, com a repetição de um mesmo programa arquitetônico básico (das 52 escolas construídas, 45 escolas atenderam ao mesmo programa com pequenas variações e 7 escolas contemplaram programas mais complexos e específicos, como escola vocacional, escola rural, escola para "aulas ao ar livre", escolas com ambientes como auditório, equipamentos esportivos com ginásios e piscinas, oficinas industriais e salas específicas para deficientes mentais); - repetição do mesmo projeto em casos muito específicos, onde a topografia e a insolação permitissem (o engenheiro Ernest Mange usou a mesma volumetria em diferentes situações topográficas tendo como resultando edifícios com distribuição de ambientes variada; Hélio Duarte usou o mesmo projeto no Bairro da Lapa e em Indianópolis);

- repetição dos mesmos blocos funcionais em arranjos que se diferenciavam a 
partir de sua topografia e insolação (ver projetos ao final deste capítulo);

- elaboração de componentes construtivos; muitos projetos apresentavam as mesmas pranchas com os detalhes construtivos que se repetiam;

— utilização de soluções construtivas, racionais e econômicas, como a ventilação cruzada, resolvida através de tubos de fibrocimento embutidos nas paredes dos corredores das salas de aula, de planos de vidro estruturados, a partir de elementos vazados com rebaixos para receber vidros de $3 \mathrm{~mm}$ a $4 \mathrm{~mm}$ e das coberturas com telhas de fibrocimento;

- racionalização da construção, com aplicação de arcos pré-moldados para solucionar o vão de cobertura do recreio coberto;

- aplicação de soluções construtivas de fácil assimilação pelas construtoras;

— trabalho de equipe em um ambiente tal e qual uma linha de produção de fábrica, onde todos os profissionais trabalham em um salão de produção, sem divisões, com livre circulação de idéias, dúvidas e soluções; assim, as questões postas e resolvidas podem ser rapidamente assimiladas nos projetos. $\bigcirc 2^{\circ}$ Convênio Escolar produziu seus projetos como qualquer escritório de projetos, com o diferencial de produzir unicamente arquitetura pública;

- as questões de conforto da criança - acústico, térmico, de iluminação, ergonômico, deveriam ser justificadas a partir de parâmetros estabelecidos cientificamente. 


\subsubsection{O PROGRAMA ARQUITETONNICO DE 12 SALAS DE AULA}

O programa arquitetônico escolanovista adotou o trinômio aprender, recrear e nutrir, que se repetiu como padrão nas escolas do convênio escolar. Esse programa proposto sofreu variações, impostas pelo aperfeiçoamento da experiência acumulada ao longo do tempo. Assim, podemos considerar, a partir da subdivisão da escola de 12 salas de aula em três blocos funcionais (ensino, recreação e administração), o seguinte conjunto de ambientes:

- Bloco de ensino: 12 salas de aula (com 48 m²), circulação (Im para 100 alunos), sanitários ( | bacia e I mictório por sala masculina e |,5 bacia por sala feminina), museu escolar, biblioteca infantil e área para ginástica programada;

- Bloco de recreação: recreio coberto com área de 0,9 m²/aluno ou $300 \mathrm{~m}^{2}$, contemplando cinema recreativo com palco para apresentações, vestiários e sanitários (repete critério já exposto);

- Bloco Administrativo composto por três sub áreas:

a) área de administração propriamente dita, com salas para diretoria $\left(10 \mathrm{~m}^{2}\right)$, secretaria $\left(16 \mathrm{~m}^{2}\right)$, arquivo, material escolar $\left(6 \mathrm{~m}^{2}\right)$, sala de professores com biblioteca didática $\left(20 \mathrm{~m}^{2}\right)$, almoxarifado e cômodo dos serventes.

b) área de assistência escolar, abrangendo as especialidades: atendimento médico $\left(10 \mathrm{~m}^{2}\right)$, atendimento dentário dentárias $\left(10 \mathrm{~m}^{2}\right)$, atendimento social e de nutrição (nutricionista, cozinha e distribuição de alimentos);

c) zeladoria com apartamento próprio para o(a) zelador(a). 
(Obs.: as áreas discriminadas correspondem às áreas recomendadas pelo projeto econômico proposto pelo convênio)

O bloco de ensino era constituído, na maioria das vezes, por 2 pavimentos e salas de aula para 40 alunos cada (com I,20 m² por aluno), formando um retângulo de $6 \mathrm{~m} \times 8 \mathrm{~m}$ já tradicionalmente encontrado nas escolas públicas desde os primeiros edifícios escolares construídos no século 20, totalizando $48 \mathrm{~m}^{2}$ por sala (as 4 salas das pontas eram maiores para proporcionar arranjos espaciais diferentes da organização tradicional da sala de aula).
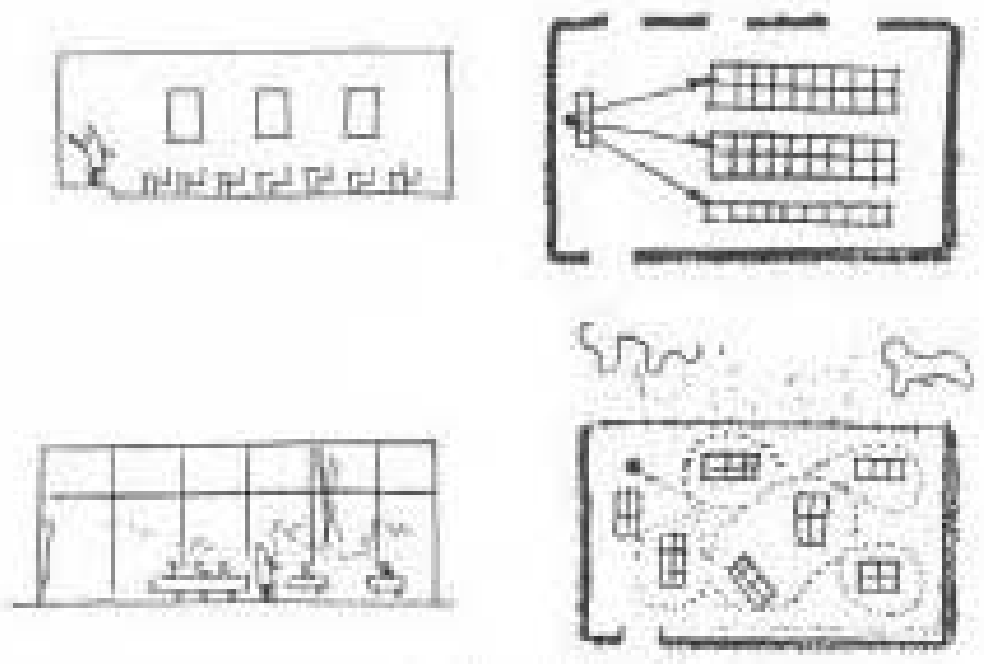

CROQUI DE HÉLIO DUARTE - AS NOVAS RELACÕES COM 0 ESPACO EXTERNO E A POSSIBILIDADES DE ARRANJO DO MOBILIÁRIO 
O bloco de recreação, por sua vez, era composto por recreio coberto em abóbada estruturada através de elementos pré-moldados de concreto ou madeira, contendo um palco (houve propostas para que fosse móvel), vestiários e cabines de projeção. $\bigcirc$ pilotis foi adotado como recreio coberto em escolas, quando havia exigüidade de terreno, ou quando a topografia acidentada possibilitava o aproveitamento do desnível ou ainda quando o programa de necessidades mais extenso exigia área maior de terreno para a construção de edificações de maior porte.

O bloco administrativo, térreo na maioria das escolas, apresentava pequenas aberturas, uma vez que, por princípios econômicos e de conforto da criança, as grandes aberturas deveriam estar nas salas de aula.

Sobre o custo dos edifícios, Hélio Duarte argumentava que "a valorização social da escola como agrupamento unitário e ponto focal de uma comunidade, levando-a a um uso intensivo, estaria, no mínimo, a duplicar o seu valor de uso e, na mesma proporção, a reduzir o seu valor de custo".

O grupo de arquitetos, liderado por Hélio Duarte, apresentou uma versão econômica para a escola idealizada por Anísio Teixeira e foi, por ele, reconhecida como escola modelo:

"Possam estes prédios escolares concebidos em juventude, ardentes e elegantes como potros de raça, impacientes de dinamismo e de amor à vida, comunicar a educação e, pela educação, a existência brasileira, as suas finas e altas qualidades de inteligência, coragem e desprendida confiança no futuro. O Brasil precisa para se realizar de lirismo - que é a capacidade de se esquecer - e de virtude - que é a capacidade de se superar. A sua arquitetura moderna é uma lição magnífica dessas duas atitudes redentoras". (in Anísio Teixeira - Revista Habitat n²4) 


\subsubsection{CONSIDERAÇÃOES COM A CIDADE, O BAIRRO E 0 ENTORNO IMEDIATO}

A premissa que orientou a construção das escolas do $2^{\circ}$ Convênio Escolar caracterizou a escola como equipamento da comunidade, do bairro onde foi implantada, e para tanto ficou estabelecido que elas abrangeriam um raio de, no máximo, 1,5 km, de forma a se tornarem acessíveis a todas as crianças de seu entorno. Como vimos no Capítulo 2, a cidade crescia desordenadamente em extensão e por isso edifícios escolares menores, distribuídos de modo a servir a pequenas comunidades atenderiam de maneira mais coerente esse modelo de cidade que São Paulo revelava.

A combinação das escolas com os teatros distritais, construídos pelo convênio, as bibliotecas e os parques infantis fizeram desses conjuntos de edifícios públicos praças de serviços nos bairros onde foram implantados, e equipamentos estruturadores nos bairros que cresciam sem planejamento e sem oferta desses serviços. Exemplo deste resultado encontramos na Escola Pandiá Calógeras que, junto ao Teatro Arthur de Azevedo na Mooca, configurou-se em uma praça de serviços públicos.

"Inicialmente na sua condição mais primária, a escola mínima assemelhase a uma ameba. É um ser unicelular. Pode ser representado por, apenas, uma sala de aula. Seu crescimento corre paralelo à satisfação das necessidades baseadas no aumento da densidade infantil e, assim, vai o organismo, em processo evolutivo, tramando uma rede de tecidos e se diferenciando em funções especializadas, até que atingindo o ápice do processo, estacione. Suas linhas de 
influência ficam limitadas, então, a um círculo de raio igual a 1500 m, abrangendo o máximo das solicitações externas. Ao dar corpo, no entanto, ao organismo, encontramos incidências físicas que nos levam a soluções as mais diversas no intuito de harmonizá-las com a programação admitida. A topografia quase sempre torturada, os ventos nocivos, as proximidades indesejáveis, a orientação magnética e solar, o panorama; tudo tem que entrar em consideração." (in Hélio Duarte, 1949, Habitat n 4)

A cidade moderna, a partir do modelo "corbusiano", rompeu com a quadra tradicional, que se definia pelo desenho dos edifícios. As escolas do convênio escolar, resultantes desse modelo, distribuíram seus três volumes funcionais sobre o terreno, de modo a buscar a melhor insolação e a melhor relação entre espaço construído e espaço livre. $\bigcirc$ espaço livre emoldurou os volumes, destacando a presença da escola no bairro que se implantava.

Os vazios resultantes, configuraram-se em espaços que se integravam ao entorno, de modo a garantir o contato direto das crianças com a natureza e o contato direto com a vida do bairro, pois, afinal, a escola deveria estar onde a vida acontece, apregoava o educador Anísio Teixeira. Cidade e natureza assim se complementavam, conforme apregoou Le Corbusier em seus tratados sobre o urbanismo moderno.

As escolas, assim implantadas, revelavam seus espaços para o bairro, e as crianças eram vistas por seus pais e vizinhos correndo pelos espaços livres, a qualquer hora do dia, e desse modo toda a comunidade era convidada a usufruir, nos períodos fora do horário das aulas, dos mesmos espaços e equipamentos. Foi proposto, inclusive, que as escolas não deveriam ser muradas, permitindo, através de 
sua transparência, a integração com o bairro no qual se inseria. Hélio Duarte em defesa da gradual retirada dos muros das escolas argumentava:

"Não haverá perigo de ser danificada a coisa pública. Já o vimos e sentimos. Basta uma ação educativa junto aos escolares e seus pais. Os resultados têm sido surpreendentes. E é porque a nossa gente é de boa índole. Ela está descrente apenas. Nós todos, juntamente a faremos voltar a ter fé nos que a dirigem se estes prometerem apenas aquilo que sabem poder cumprir, e cumprirem aquilo que prometeram". (Trecho da palestra de Hélio Duarte na Biblioteca Mário de Andrade em outubro de 1949) 
3.3 ANÁLISE DOS PROJETOS CONSTRUÍDOS 
"Esse dinamismo leve e aéreo, de fluidas formas planas é, como se sabe, uma das marcas mais reconhecíveis da arquitetura carioca das décadas de 1930 e 1940, celebrizada na produção de figuras como Affonso Eduardo Reidy, irmãos Roberto e Oscar Niemeyer. Contudo, caracteriza uma produção que, àquela altura, já se havia difundido enormemente pelo país, a ponto de torna-se dominante na obra de arquitetos "paulistas" nesse período, tais com Rino Levi - Instituto Sedes Sapientae, 1941, e Vilanova Artigas - com a Casa da Criança e Rodoviária de Londrina, 1950. Desse modo, não é surpresa alguma a adoção dessa linha mestra nos projetos do Convênio, desenhados por uma equipe chefiada por Hélio Duarte (...)" (Gulherme Wisnick in Arquitetura Escolar Paulista: anos 1950 e 1960, pág 62.)

A composição do conjunto arquitetônico característico das escolas do $2^{\circ}$ Convênio Escolar, a partir da articulação de diferentes volumes definidos pelos blocos funcionais (de ensino, de recreação e de administração), conectados entre si por marquises, formando diferentes arranjos espaciais, a partir da racional distribuição dos fluxos de alunos, público e comunidade, e da adequação à topografia existente e sua insolação correspondente, possibilitaram que esses volumes, isoladamente, pudessem, em alguns casos, ter o mesmo tratamento arquitetônico, em atendimento ao grande número de escolas a ser construído.

Os diferentes arranjos desses três volumes funcionais e a tipologia das coberturas dos recreios cobertos (cobertura em abóbadas, em pilotis e cobertura "asa de borboleta") configuraram a originalidade e a especificidade de cada solução volumétrica resultante.

De todo o conjunto de 52 escolas construídas pelo $2^{\circ}$ Convênio Escolar, a maioria resultou em uma implantação feita a partir dos 3 blocos funcionais (de ensino, 
de recreação e de administração) articulados através de marquises. Algumas escolas (5 no total de 52), devido à extensão dos programas, exigüidade dos terrenos e topografia acidentada resultaram em um único volume, no qual se organizaram todas as funções.

Por sua vez, dos 47 edifícios compostos a partir da articulação de diferentes volumes, 20 edifícios apresentaram blocos de recreação em abóbadas, blocos administrativos térreos e blocos de ensino com 2 pavimentos.

Os projetos que não utilizaram o recreio coberto por abóbada apresentaram justificativa técnica para a aplicação de solução alternativa. $\mathrm{Na}$ análise dos 27 edifícios que não resultaram no partido do recreio coberto em abóbada encontramos 23 edifícios escolares com o recreio em pilotis: desses 23 edifícios escolares, I4 foram implantados em terrenos com topografia acidentada e, assim, a partir do princípio de economia, fez-se uso do pilotis através do aproveitamento dos desníveis naturalmente existentes; outros 5 edifícios escolares necessitaram atender a programas muito extensos, determinando novamente a solução em pilotis, a fim de garantir um uso mais racional do terreno; por último, 4 edifícios escolares foram implantados em terrenos muito exíguos, impossibilitando também o uso do recreio abóbadado.

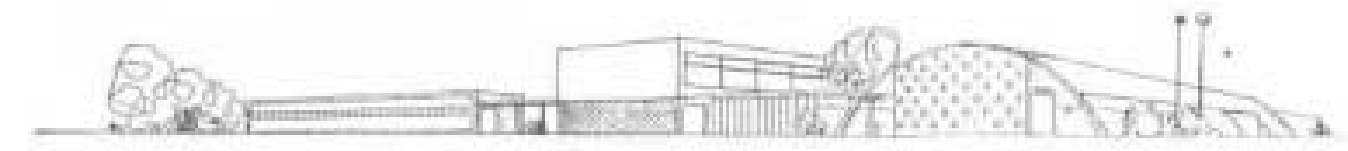

CROQUI MOSTRA A RELAÇ̃̃o ENTRE OS TRÊS VOLUMES BáSICOS, ADMINISTRATIVO (TÉRREO); DE ENSINO (2 PAV) E RECREIO EM ABÓBADA. 
Os 4 edifícios restantes, para complementarmos os 27 edifícios escolares que não resultaram em recreio coberto com abóbada, apresentaram, como solução da cobertura de seu recreio, o telhado com desenho em asa de borboleta.

Mesmo sendo o pilotis a solução adotada pela maioria das escolas (23 do total de 52), foi o recreio em abóbada (20 do total de 52) o modelo consagrado e que identifica um projeto feito pelos arquitetos do $2^{\circ}$ Convênio Escolar.

As diferentes combinações dos três volumes funcionais dispostos livremente nas implantações, típicas da arquitetura carioca, resultaram na versatilidade dos projetos e atenderam plenamente às necessidades técnicas colocadas pelos novos edifícios do $2^{\circ}$ Convênio.

Como dizia Hélio Duarte, os edifícios devem ser postos e não impostos aos lugares; assim, o uso das abóbadas se limitou a situações que tecnicamente se justificavam - adequação à topografia existente e à área do terreno disponível versus programa a ser atendido.

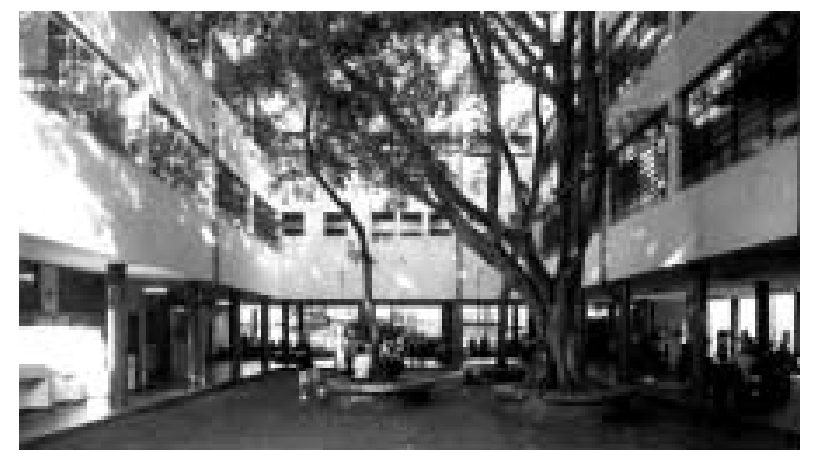

PILOTIS ERGUEM 0 EDIFÍCIO DO CHÃO E CRIAM ESPACO DE RECREACÃO EE NOSSA SENHORA DA PENHA - ARQUITETO EDUARDO CORONA 


\subsubsection{BREVE BIOGRAFIA DE HÉLIO DUARTE}

Moderno peregrino e educador, assim Hugo Segawa qualifica o arquiteto Hélio Duarte. Logo que se diplomou em 1930, antes da gestão de Lúcio Costa, portanto, com uma formação tradicional Belas Artes, Hélio Duarte participou, no Rio de Janeiro, da elaboração dos planos urbanísticos para as cidades de Recife, João Pessoa e Cabedelo, ao trabalhar na equipe do arquiteto Nestor de Figueiredo. Saiu pelo Brasil, em 1936, ao ser transferido para a Bahia pelo Banco Hipotecário Lar Brasileiro, empresa em trabalhou ao ser aprovado em concurso, no ano de 1934.

Conforme Hugo Segawa relata-nos, em artigo para a revista AU, de outubro de 1998, Hélio Duarte, em sua passagem por Salvador, teve um primeiro contato com a arquitetura moderna, mas, apesar de divulgar a arquitetura de Le Corbusier e André Lurçat na Escola de Belas Artes de Salvador em 1936, não aplicou os princípios modernistas em suas obras correntemente; em 1938, iniciou sua carreira docente nessa faculdade.

No ano de 1938, foi contratado como arquiteto chefe da Companhia Brasileira Imobiliária e de Construções, onde teve a oportunidade de edificar seu projeto para o edifício Bráulio Xavier, exemplo da aplicação dos princípios da arquitetura moderna.

Em 1944, foi transferido para São Paulo, em função de seu trabalho na Companhia Brasileira Imobiliária e de Construções. Entre os anos de 1945 e 1947, manteve escritório paralelo de arquitetura, em sociedade com Zenon Lotufo e Abelardo de Souza, onde desenvolveu inúmeros e expressivos projetos, de acordo com a moderna arquitetura carioca. Hélio Duarte, em São Paulo, teve uma intensa vida profissional e participou junto ao Instituto de Arquitetos do Brasil, da organi-

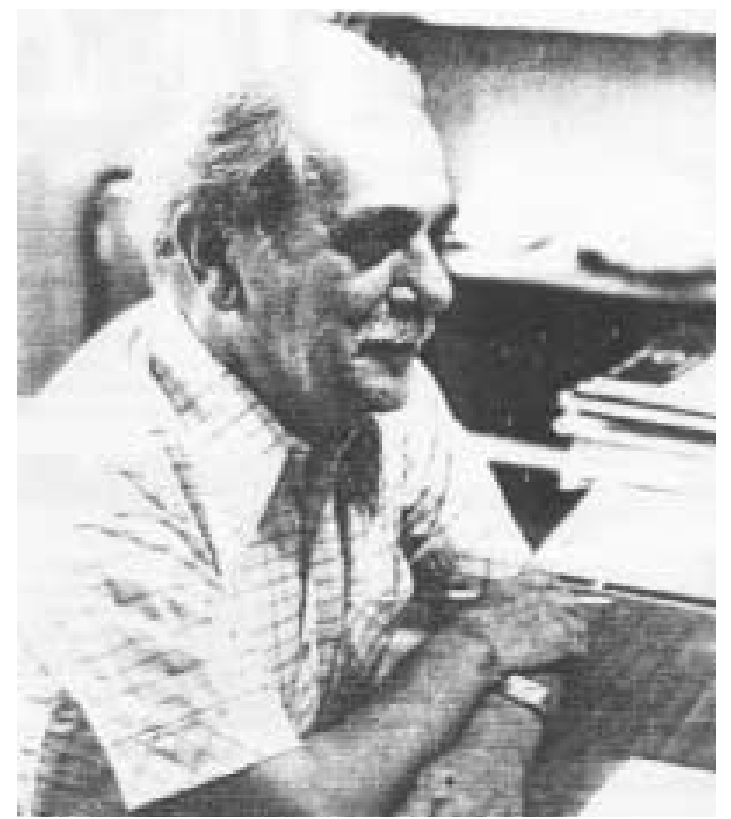

ARQUITETO HÉLIO DE QUEIROZ DUARTE 


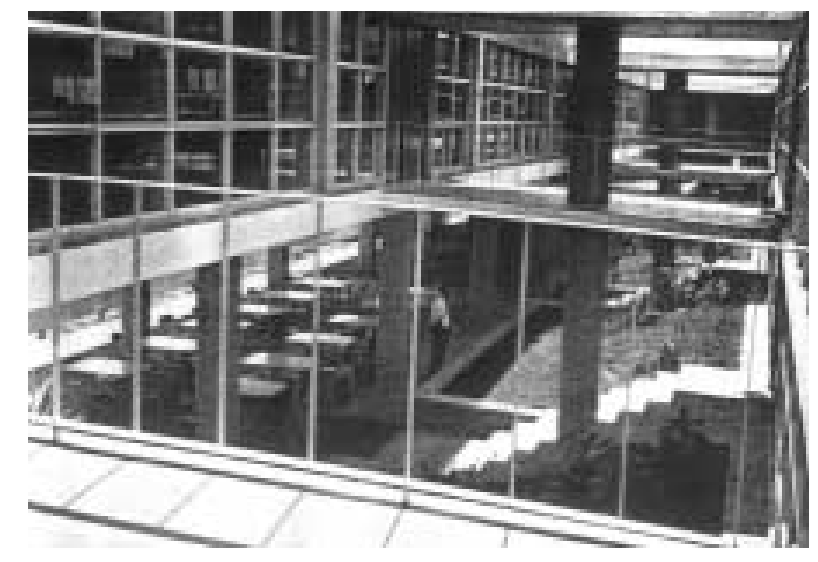

SENAI BRÁS - PROJETO HÉLIO DUARTE E ERNEST MANGE

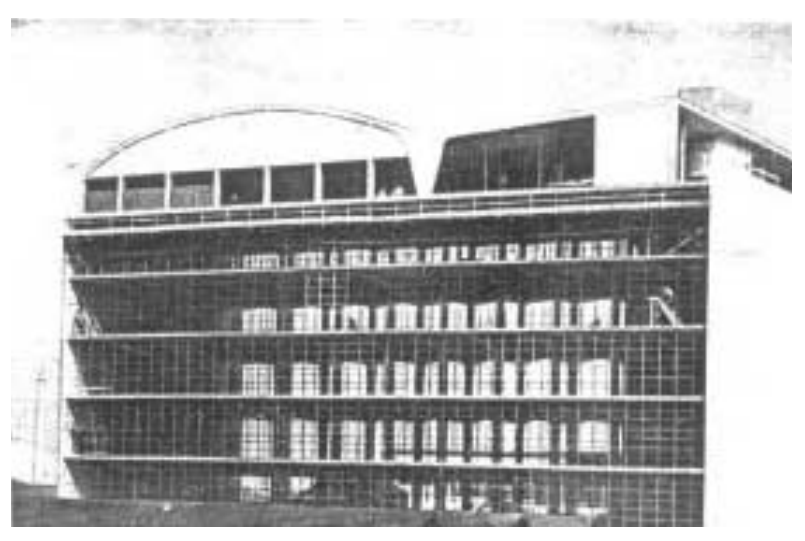

VISTA DO BLOCO DE OFICINAS DA ESCOLA TÊXTIL DO BRÁS zação do $1^{\circ}$ Congresso Brasileiro de Arquitetos de 1945; nesse mesmo ano, foi convidado por Richard Neutra para integrar, como representante brasileiro, o Congresso Internacional de Arquitetura Moderna (CIAM).

Para desenvolver tantas atividades profissionais, simultaneamente, Hélio Duarte executou a maioria de seus projetos em equipe: foi com uma grande equipe que participou da execução do projeto para a Sede do Instituto de Arquitetos do Brasil (IAB) de São Paulo.

Em 1948, desligado da Companhia Imobiliária Brasileira e fora da sociedade com Zenon Lotufo e Abelardo de Souza, passou a se dedicar, na prefeitura de São Paulo, à Comissão Executiva do Convênio Escolar, programa do qual se desligou em 1952.

É também merecedora de nota sua participação no projeto do IAPC Cidade Jardim, em 1947, Convidado pelo arquiteto Eduardo Kneese de Melo, projetou a creche, o jardim de infância, a escola primária, o grupo social, a maternidade e o ambulatório. Também no ano de 1948, ao integrar a equipe do Convênio Escolar, participou da elaboração do plano para o Centro Educacional Carneiro Ribeiro na capital baiana (a definição final dos edifícios coube ao arquiteto Diógenes Rebouças), ao lado do educador Anísio Teixeira, cuja importância já vimos no capítulo anterior.

Paralelamente às atividades no $2^{\circ}$ Convênio Escolar, a partir de 1950, iniciou sociedade com o engenheiro Ernest Robert de Carvalho Mange, também membro da Subdivisão de Planejamento do Convênio Escolar.

Essa sociedade manteve-se até o ano de 1955. Muito profícua, rendeu vários projetos, entre os quais se destacam os projetos para o SENAI de São Paulo (criado em 1942) - foram projetados e construídos a Escola Técnica da Vila Mariana, a Escola Têxtil Central no Brás, o Internato de Campinas e o Pavilhão Social do Brás, projetos que marcaram a arquitetura moderna em São Paulo. 
Outras frentes de trabalho significativas do escritório referem-se aos planos urbanísticos para os campi universitários da Faculdade de Engenharia de São Carlos, projeto de 1952, e para a Cidade Universitária de Santa Catarina, projeto de 1955.

A partir de 1955, já finalizada a sociedade com Ernest Mange, dedicou-se à chefia do escritório de Engenharia e Arquitetura da Comissão da Cidade Universitária de São Paulo. Nessa atuação teve relevo a elaboração do Roteiro para Replanejamento da Cidade Universitária Armando de Salles Oliveira, quando, então, foi planejado um Core, espaço de encontro e vivência para a comunidade universitária, de acordo com o $8^{\circ}$ Congresso Internacional de Arquitetura Moderna (CIAM), ocorrido em 195I, em que foi eleito o tema "Humanização da Cidade", que destacou a importância da apropriação pela comunidade dos espaços públicos, ou seja, segundo o $8^{\circ} \mathrm{CIAM}$, o racionalismo modernista deveria ser revisto, humanizado, colocando o modo de apropriação do espaço por um determinado grupo social como uma variante projetual a ser atendida. Na realidade, as posturas de Hélio Duarte durante o $2^{\circ}$ Convênio Escolar, reveladas na sua preocupação em formar comunidades de bairro, mostraram que não havia novidade para o humanista Hélio Duarte nessa revisão conceitual proposta pelo $8^{\circ} \mathrm{CIAM}$. Suas posturas em colocar o homem como centro das questões espaciais já indicavam, há tempos, esse caminho.

Em 1949, Hélio Duarte retornou ao ensino de arquitetura na Faculdade de Arquitetura e Urbanismo da Universidade de São Paulo (FAUUSP), onde foi um dos pioneiros arquitetos que, exercendo plenamente sua profissão, em paralelo a uma consistente carreira acadêmica, formou uma primeira geração de doutores, ao organizar o curso de pós-graduação dessa faculdade.

Hugo Segawa resumiu a trajetória de Hélio Duarte em outras instituições de ensino:

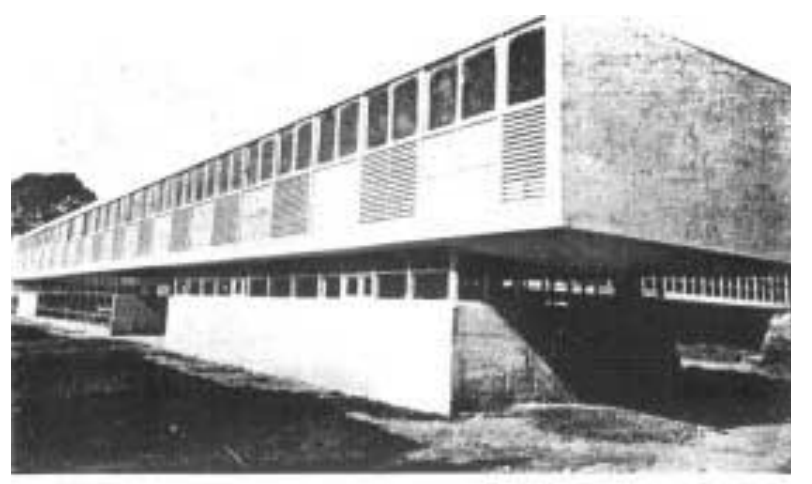

Gists srral Aormágrios!

SENAI - INTERNATO DE CAMPINAS

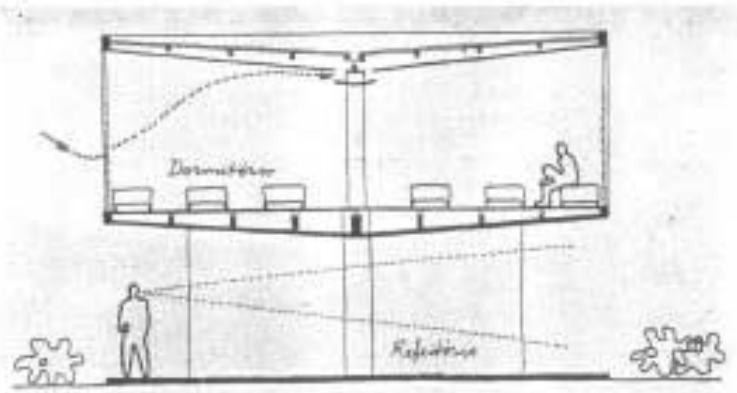

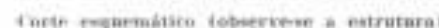

INTERNATO DE CAMPINAS - HÉlIO DUARTE E ERNEST MANGE 
"Desenvolveu atividades docentes fora da FAU em várias oportunidades: entre 1953 e 1955, foi professor da Escola de Engenharia de São Carlos; em 1965 , foi diretor e presidente da Comissão Organizadora da nascente Escola de Arquitetura da Universidade Federal do Ceará; em 1967, lecionou na Universidade de Brasília, naquele conturbado período político na capital federal, e pouco depois se envolveu também na experimental e conturbada criação do curso de arquitetura de São José dos Campos, São Paulo" (in Segawa, revista AU, 1998, pag. 64)

Hélio Duarte encerrou suas atividades profissionais como arquiteto em 1969 e, a partir daí, dedicou-se integralmente à FAUUSP, onde promoveu o Curso de PósGraduação, o primeiro do Brasil.

No curso de graduação, reestruturou $\circ 5^{\circ}$ ano do curso de arquitetura ao criar o Trabalho Final de Graduação que se tornou obrigatório e referência para todos os cursos de arquitetura de acordo com o currículo do Ministério da Educação e Cultura.

Hélio Duarte personificou a imagem de um arquiteto pouco preocupado com a exposição de sua imagem. Para ele a relevância do papel do arquiteto na sociedade estava em projetar com o propósito de atender às demandas e em resolver os diversos problemas colocados. $\bigcirc$ fazer e o ensinar a melhor arquitetura dentro das possibilidades materiais que the eram colocadas, estão registrados ao longo de toda a sua carreira, no modo como exerceu a profissão: como empregado, como funcionário público, como profissional liberal, como acadêmico.

Pouco se fala em Hélio Duarte, quando aprendemos sobre aarquitetura moderna, mas vivenciamos muito seus espaços e ensinamentos como professor da FAUUSP (mesmo não tendo sido seu aluno, fiz meuTFG e minha pós-graduação baseado 
nas estruturas garantidas por sua dedicação. Hélio Duarte foi um arquiteto que sempre se preocupou com uma arquitetura feita a serviço da comunidade, uma arquitetura posta e não imposta à sociedade, como ele próprio gostava de falar ao descrever suas escolas do Convênio Escolar - a boa técnica a serviço do ser humano. Em seu artigo na revista AU, que serviu de base para este texto, Hugo Segawa arremata: "o que perdura são os rastros e, no caso de Hélio Duarte, são rastros conseqüentes".

\subsubsection{A EQUIPE E OS 52 PROJETOS DO $2^{\circ}$ CONVÊNIO ESCOLAR}

Ospírito de equipe que animou a produção desse conjunto de edifícios escolares revelou, também, alguns traços individuais que diversificaram a produção arquitetônica do $2^{\circ}$ Convênio Escolar, em decorrência da liberdade projetual que foi garantida aos arquitetos pelo seu diretor Hélio Duarte.

A seguir, serão apresentados 37 projetos arquitetônicos do $2^{\circ}$ Convênio Escolar, agrupados por autores, com uma sucinta descrição das particularidades de cada arquiteto e, logo após, serão apresentados os 15 projetos cuja autoria não foi identificada.

Dentro de cada conjunto de projetos do mesmo autor, cada edifício escolar será classificado a partir da solução adotada para sua implantação (blocos funcionais independentes ou bloco único) e da volumetria resultante determinada pela cobertura de seu recreio (abóbada, pilotis e asa de borboleta). Ver tabela anexada mostrando resumo da análise das escolas na página 303. 


\section{ARQUITETO HÉLIO DE QUEIROZ DUARTE}

Diretor da Subdivisão de Planejamento, Hélio Duarte assinou a autoria de 10 projetos produzidos pelo $2^{\circ}$ Convênio Escolar. Foi o arquiteto com a maior produção de edifícios escolares da equipe. Sua produção sintetizou as principais diretrizes apontadas para o desenvolvimento dos projetos e, pelo fato de terem sido os primeiros, criaram uma referência para a produção do restante da equipe.

Do total de 10 escolas projetadas por Hélio Duarte, 8 apresentaram o recreio coberto abobadado, que, pré-moldado, reduzia o tempo de execução da obra; as outras 2 escolas têm o seu recreio coberto abrigado por pilotis. Seguem as escolas: 


\section{EE Almirante Barroso (1949)}

Localizado no bairro do Jabaquara a escola configurou-se a partir da tipologia típica do Convênio. Apresenta o bloco administrativo térreo acoplado ao bloco de ensino com 2 pavimentos, que se interliga, através de uma passagem coberta, ao recreio coberto em abóbada. $\bigcirc$ mesmo projeto de galpão abobadado repete-se na escola EE Visconde de Taunay (1949) e na EE Professor José Carlos Dias (1949). 

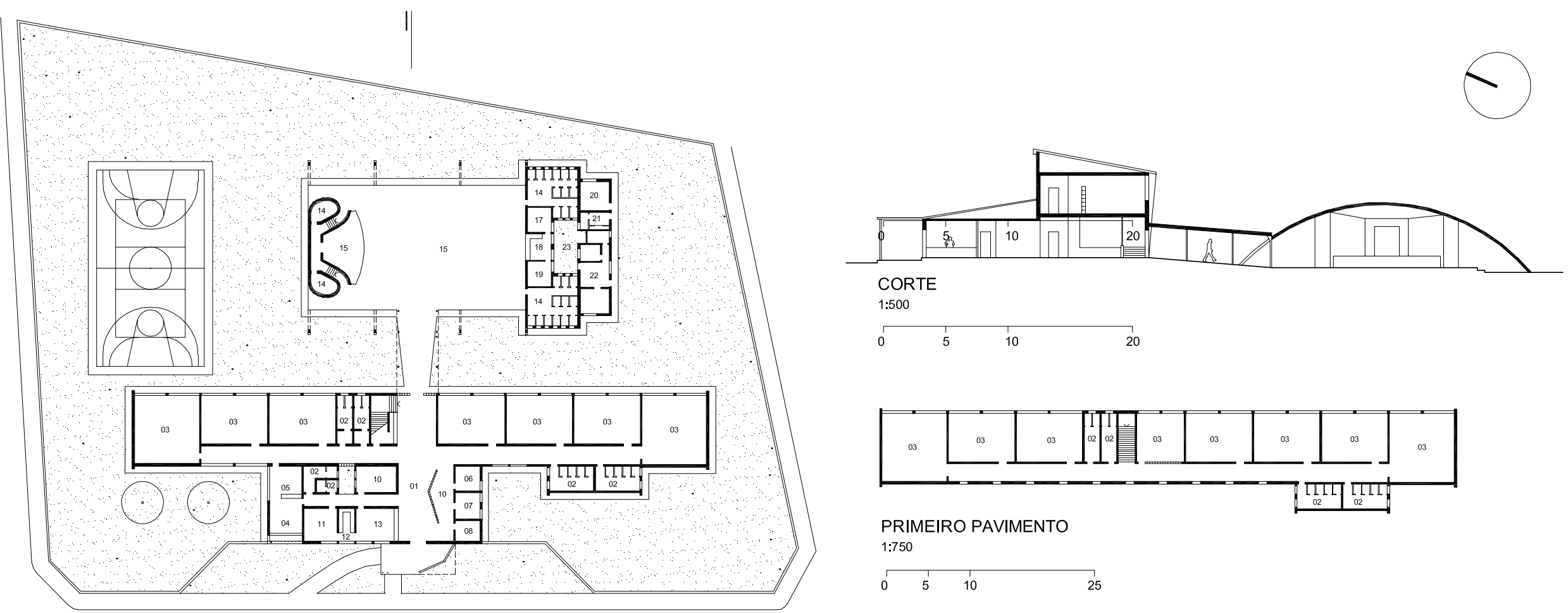

IMPLANTAÇÃO / TÉRREO 1:750
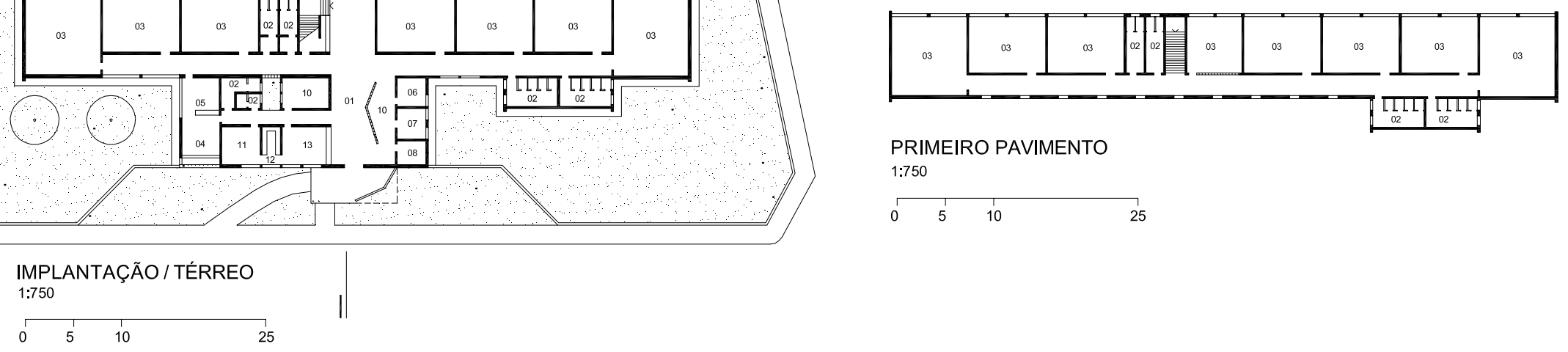

PRIMEIRO PAVIMENTO 1:750
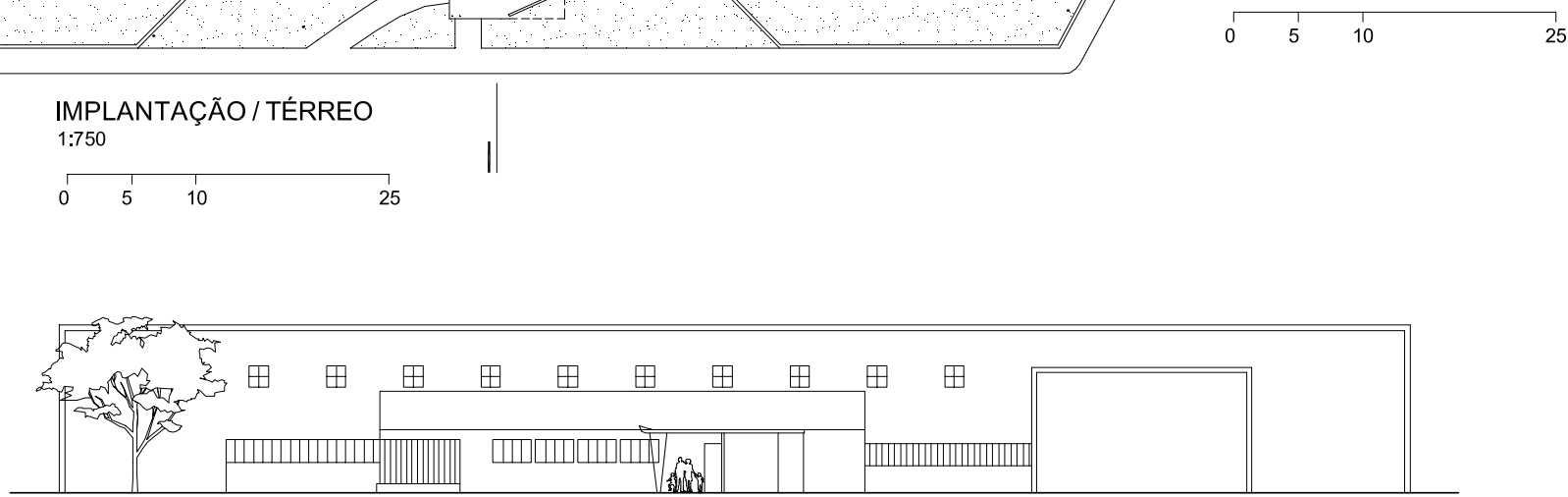

ELEVAÇÃO OESTE

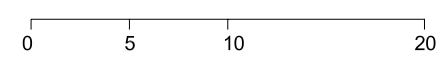

LEGENDA

01. HALL
02. SANITARIO

O4. BIBLOTECA
O5. PROFESSORES

06. DENTISTA

O8. ASSISTENTE SOC

12. ARQUIVO
13. SECRETARIA

14. VESTIARIOS

16. GALPÄO
1. COZINHA
18. DISTRIBUIÇĀO 


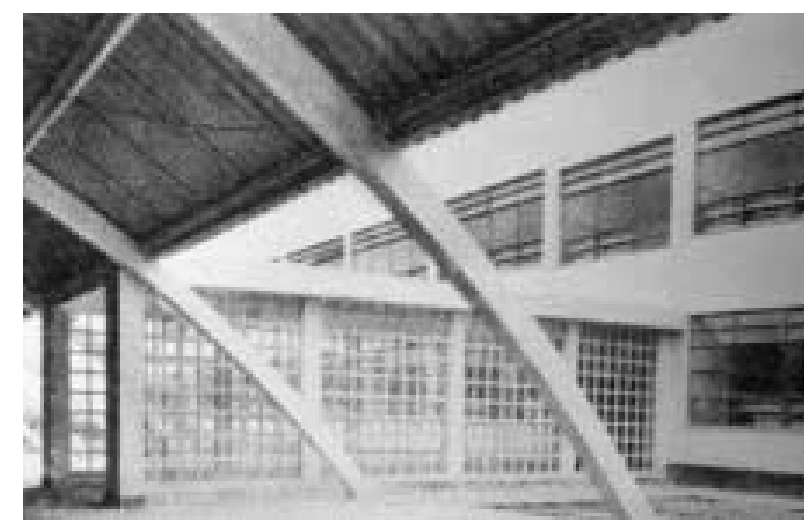

EEPG VISCONDE DE TAUNAY

MARQUISE INTERLIGA BLOCO DE ENSINO AO RECREIO EM ABÓBADA

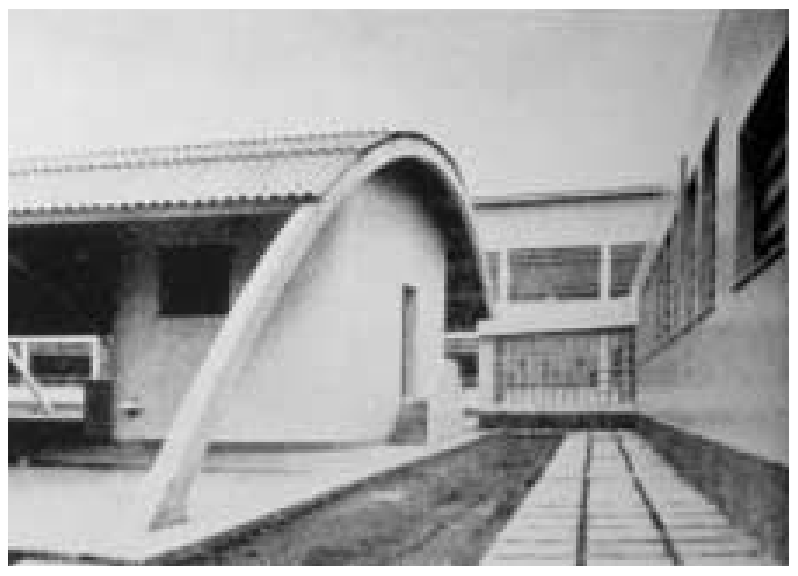

EEPG VISCONDE DE TAUNAY

VISTA 3 BLOCOS DA COMPOSIÇ̃̃O TÍPICA DO CONVÊNIO

\section{EE Visconde de Taunay (1949) e EE Professor José Carlos Dias (1949)}

Localizadas nos bairros do Limão e Casa Verde, respectivamente, as duas escolas apresentam os três blocos funcionais independentes, o bloco administrativo térreo e o bloco de ensino em 2 pavimentos que se acoplam ao recreio coberto por abóbada, através de marquises. Os projetos diferenciam-se somente pela posição e dimensão da caixa de escada, confirmando que a repetição com pequenas variações foi um dos recursos usados para a produção das 52 escolas do $2^{\circ}$ Convênio Escolar. 


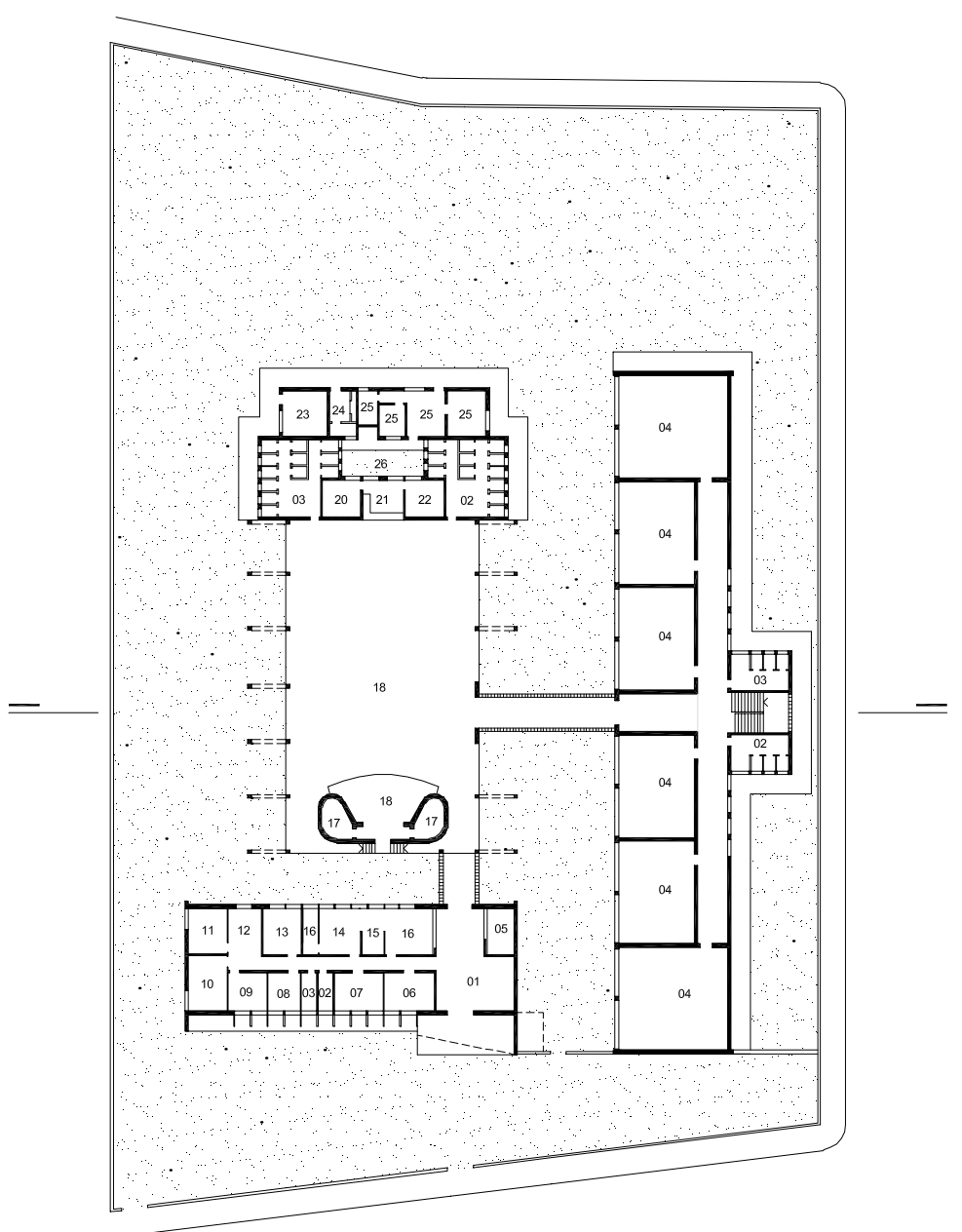

IMPLANTAÇÃO / TÉRREO

1:750

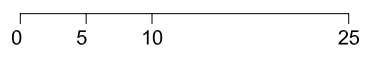

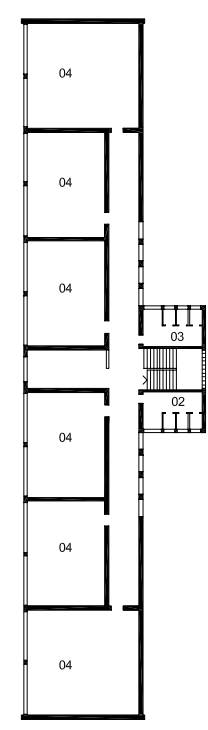

PRIMEIRO PAVIMENTO

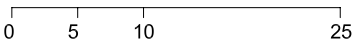

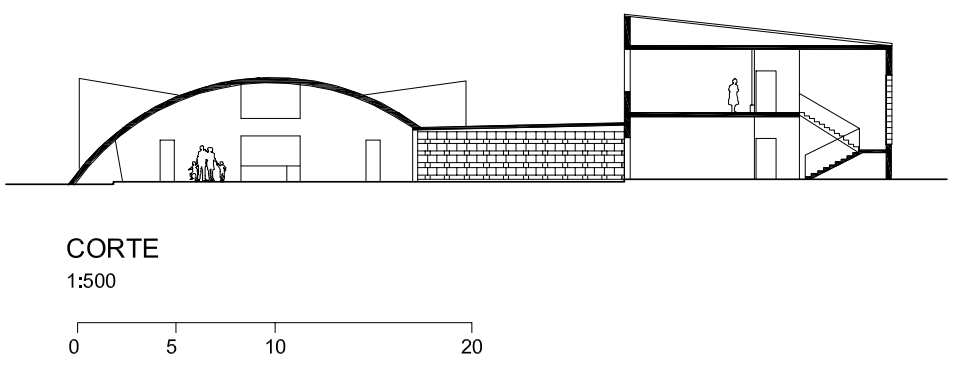

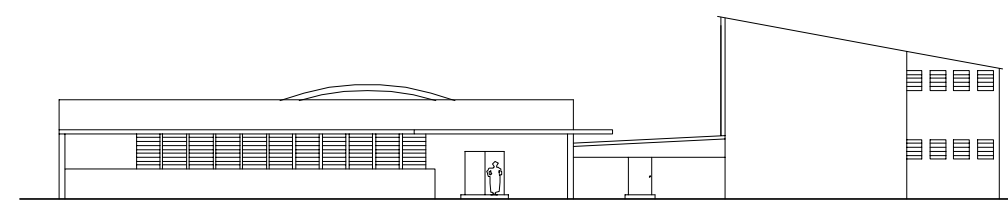

ELEVAÇÃO LESTE

1:500

\begin{tabular}{llll}
\hline & 5 & 10 & 20
\end{tabular}

LEGENDA

$\begin{array}{ll}\text { 01. HALL E MUSEU } & \text { 14. DRETTR } \\ \text { 15. ARQUUVO } & \end{array}$

03. SANITARIO FEMININO
04. SALA DE AULA

S. GUARDADOS

78. PROFESSORES

0. MÉDICO

12 SALA DE ESPERA

2. ALMOXARIFADO
1. 

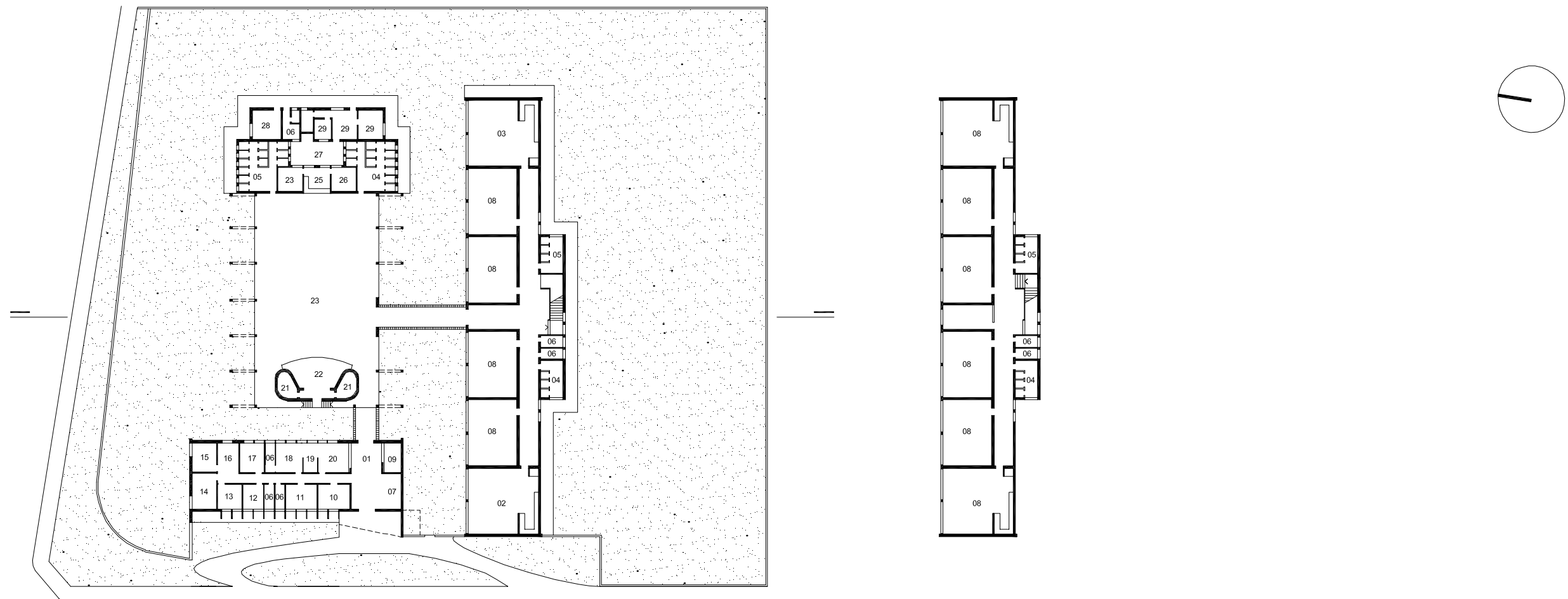

IMPLANTAÇÃO / TÉRREO

1:750

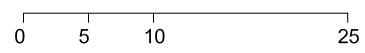

PRIMEIRO PAVIMENTO
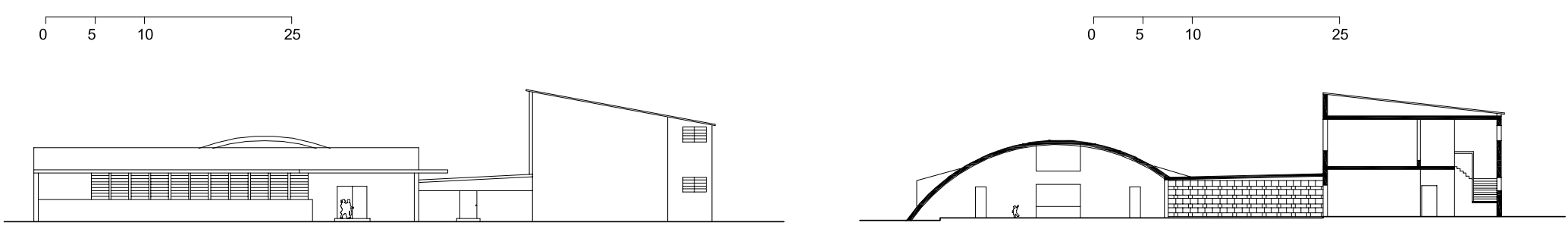

LEGENDA

01. HALL DE ENTRADA
02. MUSEU CIENCIAS

16. SALA DE ESPERA
17. ALMOXARFADO

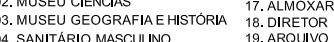

SANITARRIO FEMININO

06. SANTTARIO
O7. MUSEU

ELEVAÇÃO OESTE

CORTE

1:500

1:500

\begin{tabular}{llll}
\hline & 1 & 10 & 20
\end{tabular}

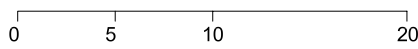




\section{EE César Martinez (1950) e EE José Monteiro Boa Nova (1951)}

A primeira escola localiza-se no bairro de Indianópolis e a segunda, no bairro da Lapa. Os dois edifícios escolares foram construídos utilizando-se do mesmo projeto arquitetônico, e, que, apesar de implantados em terrenos com diferentes configurações, apresentam insolação adequada para as salas de aula.

O partido de implantação de blocos funcionais independentes, com bloco de ensino em 2 pavimentos, bloco de recreação coberto em abóbada e bloco administrativo térreo (com marquise marcando a transição entre a escala urbana e a escala do edifício escolar), mais uma vez predomina na organização do conjunto arquitetônico

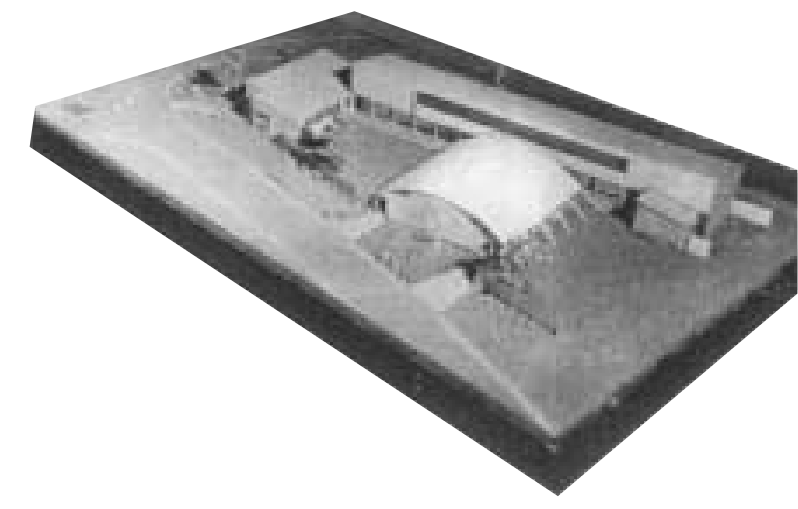

TIPOLOGIA VOLUMÉTRICA BÁSICA USADA PARA A COMPOSIC̣̃O VOLUMÉTRICA DAS ESCOLAS DO $2^{\circ}$ CONVÊNIO ESCOLAR - EE CÉSAR MARTINEZ 


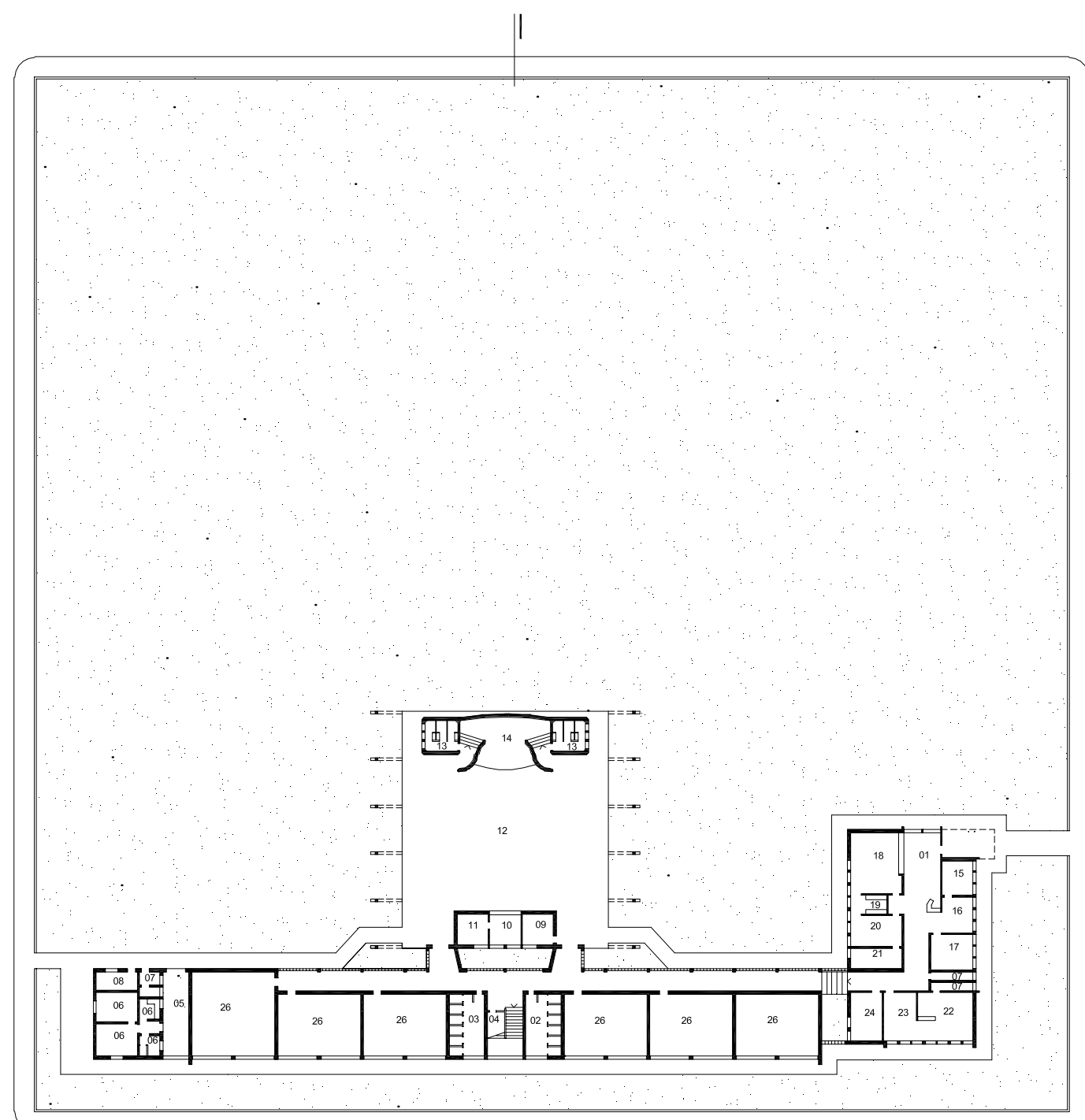

IMPLANTAÇÃO / TÉRREO 1:750

\begin{tabular}{lll}
\hline & 5 & 10
\end{tabular} 25
LEGENDA

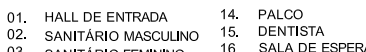

04. SANITARIO
05. DEPOSITO
PATEO

66. ZELADORI
07. SANITARIO
08

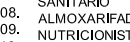

DISTRIBUIÇC̄AO

12. GALPAO

18. ADMINISTRAÇÁ

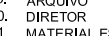

SALA DOS PROFESSORES

24. ASSISTENTE SOCIAL
25. SALA DE PROJEÇAO
$26.5 A L A D E A U L A$

26. VALA VAE AULA
VAIO

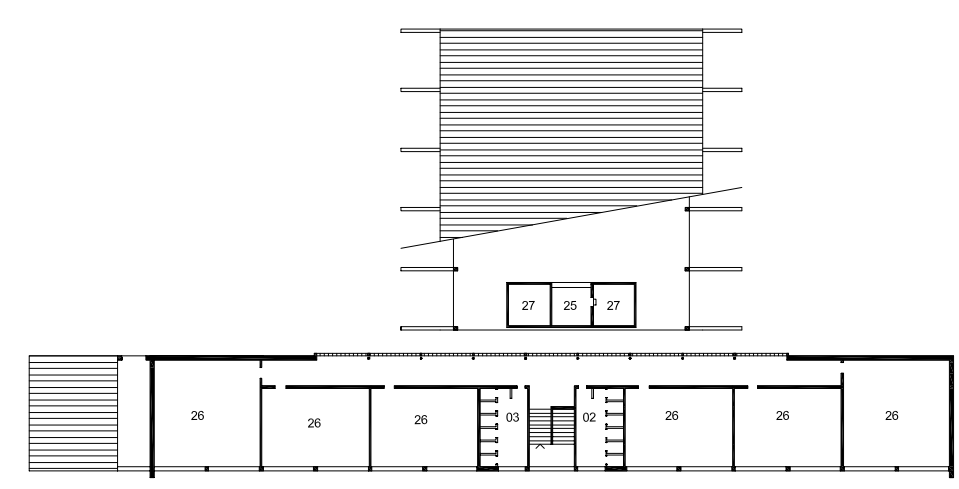

PRIMEIRO PAVIMENTO 1:750

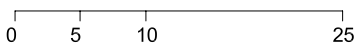



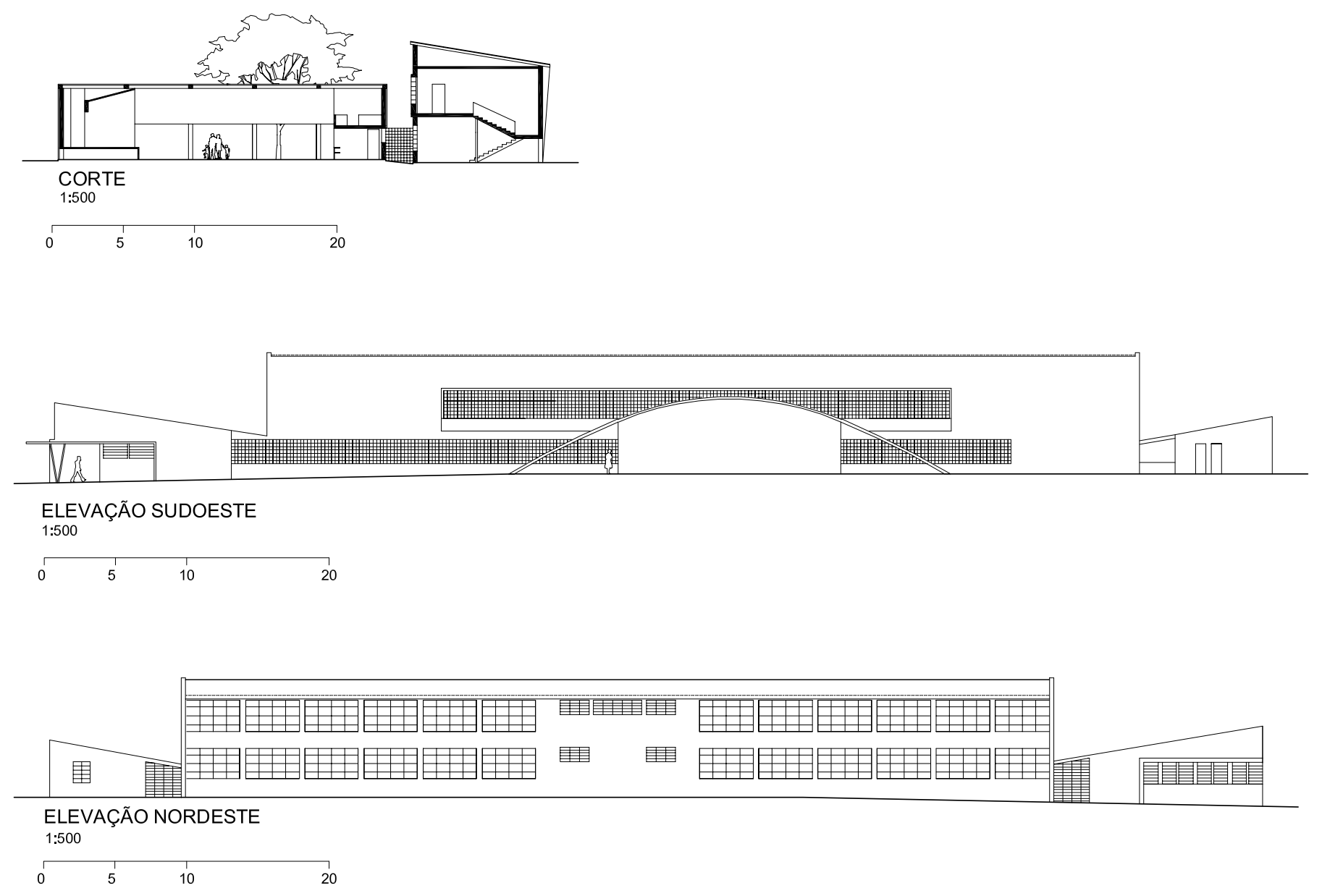


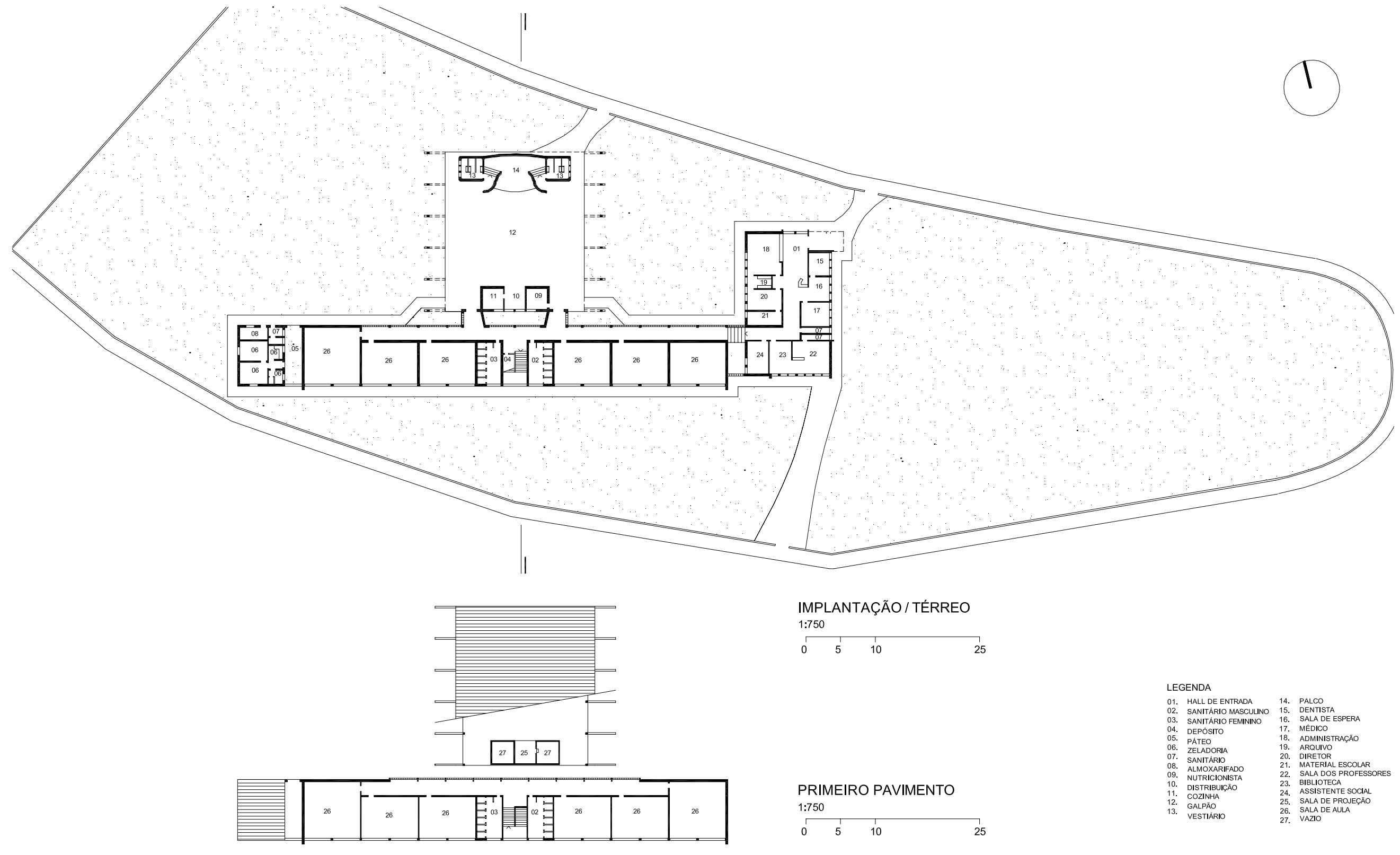



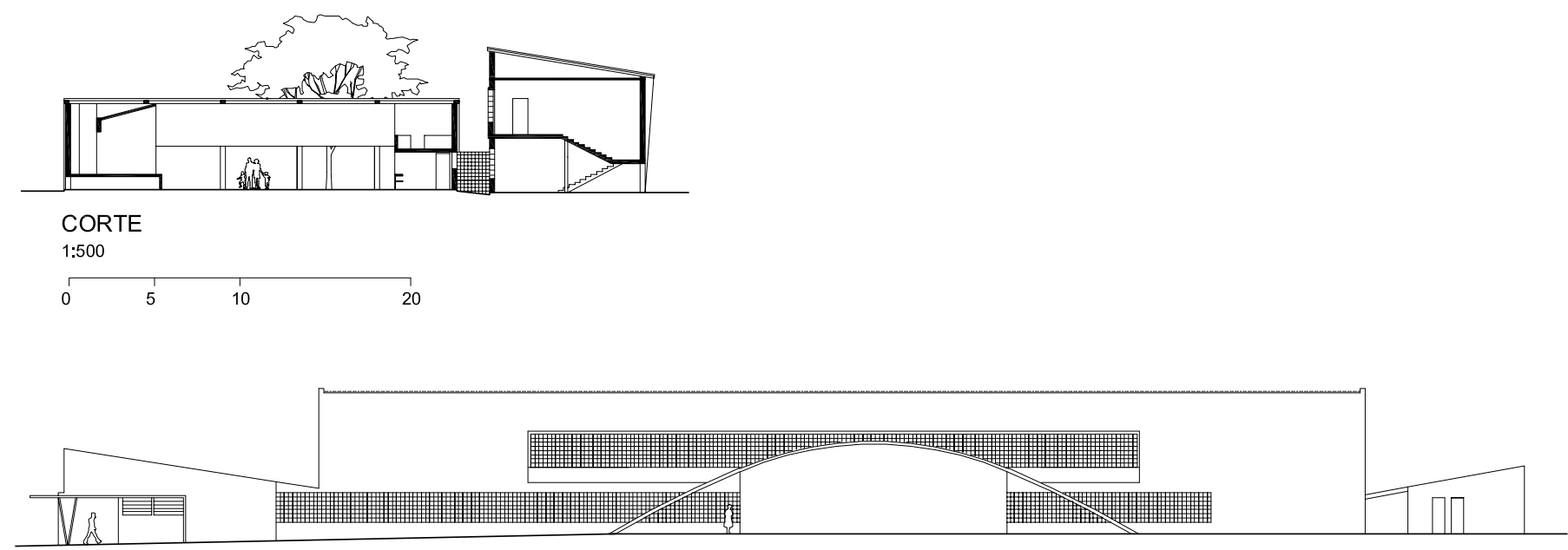

\section{ELEVAÇÃO NORTE}

1:500
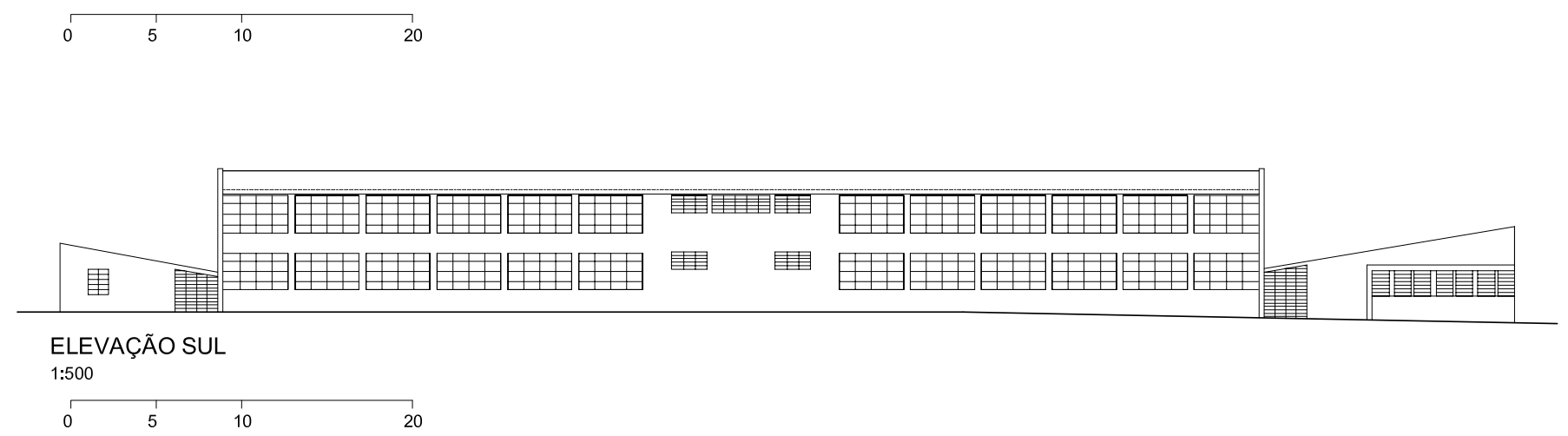


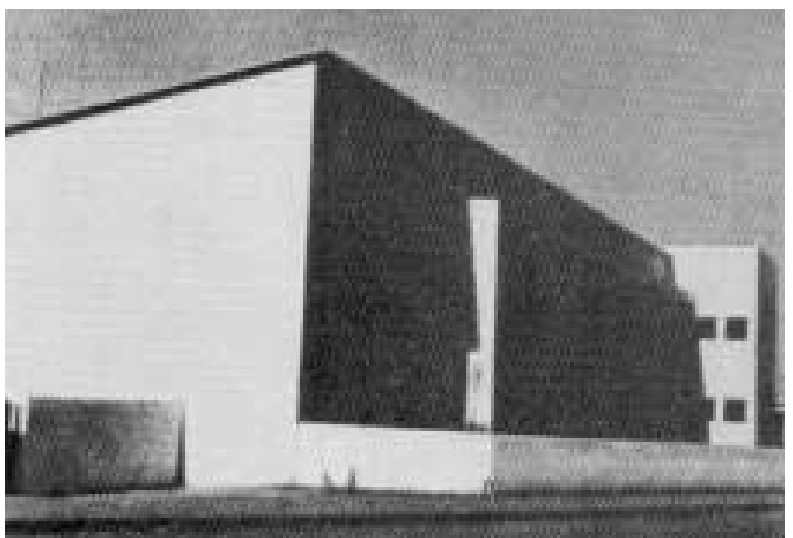

VOLUMES DESTACADOS DO VOLUME PRINCIPAL

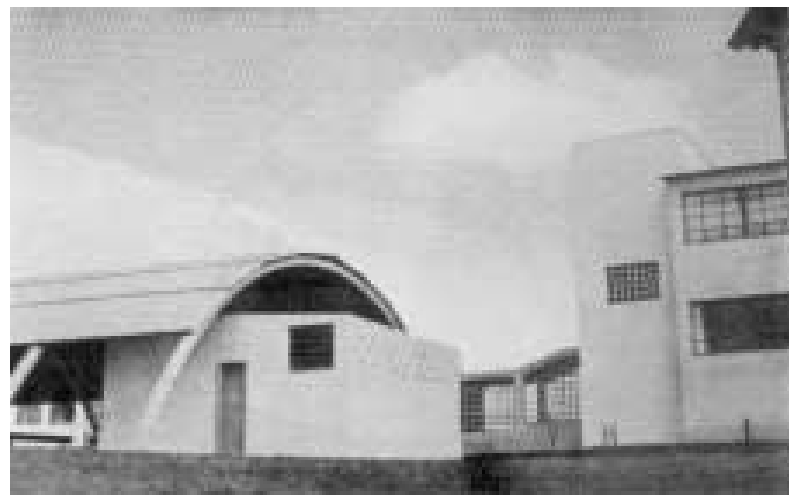

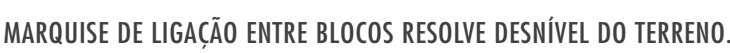

\section{EE Doutor Murtinho Nobre (1950)}

Localizada no bairro do Cambuci, repete o partido de blocos funcionais independentes com o bloco de ensino em 2 pavimentos, bloco de recreação coberto por abóbada e bloco administrativo térreo.

Sua implantação difere dos demais projetos que usam essa mesma tipologia de implantação, em função da topografia existente, que apresenta um desnível entre o recreio coberto e o bloco de ensino, desnível resolvido através de marquise que acompanha a inclinação do terreno.

A marquise de entrada, desortogonalizada, convida à entrada e faz a transição da escala urbana para o espaço construído da escola na conexão de circulação entre os três blocos funcionais. Detalhes sutis e econômicos, como esse, revelam a intenção presente nos projetos do convênio de convidar a comunidade do bairro a entrar na escola e a participar dos espaços das crianças. 


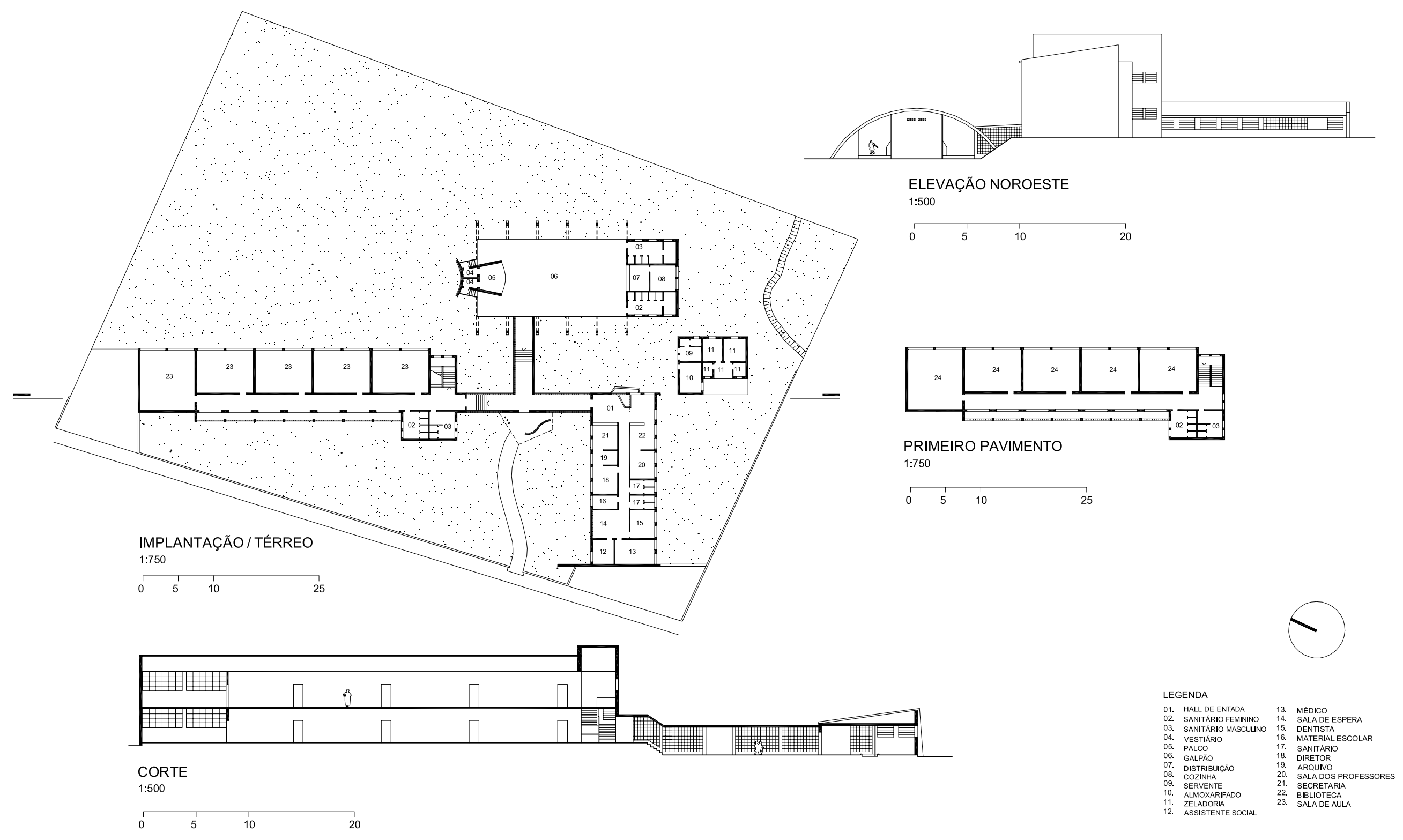




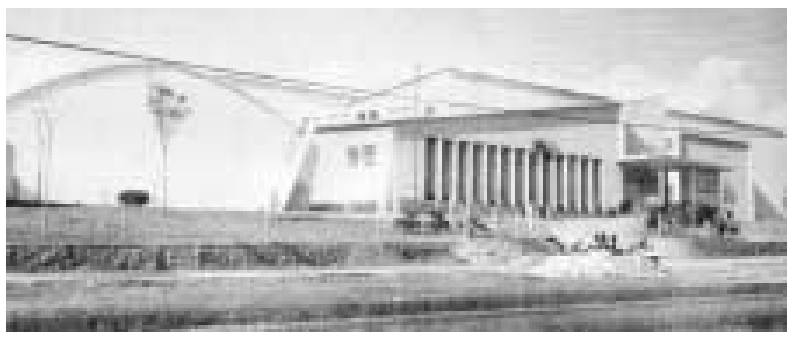

FACHADA PRINCIPAL QUE SE ABRE PARA A AVENIDA PAES DE BARROS

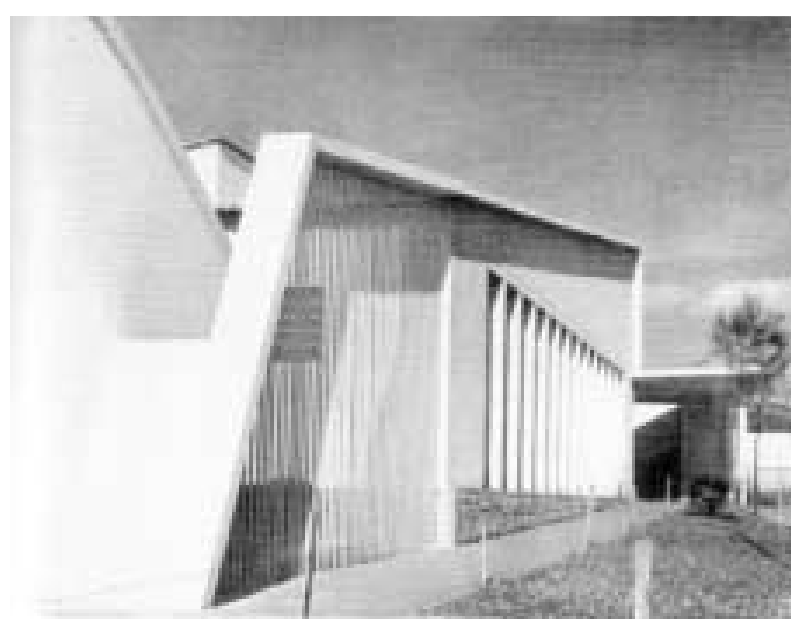

ENCONTRO ENTRE DIFERENTES VOLUMES RESOLVIDO COM A UTILIZAÇÃO DE MUXARABIS

\section{EE Pandiá Calógeras (1949)}

Localizada no Bairro da Mooca apresenta uma implantação compacta em relação às outras escolas, uma vez que parte de seu terreno foi reservado para a construção do Teatro Arthur de Azevedo, na intenção de criar um conjunto de equipamentos urbanos que estruturasse e criasse referência no desenho do bairro.

Essa escola repete a tipologia básica de blocos funcionais independentes articulados, com o bloco de ensino em 2 pavimentos, bloco de recreação coberto por abóbada e bloco administrativo térreo, além de repetir a marquise que faz o estratégico papel de transição entre as escalas da cidade e da criança: no desenho de implantação notamos a continuidade natural da calçada até encontrar a porta de acesso marcada pela marquise de entrada.

A escola organiza sua circulação através de um pátio central descoberto. 


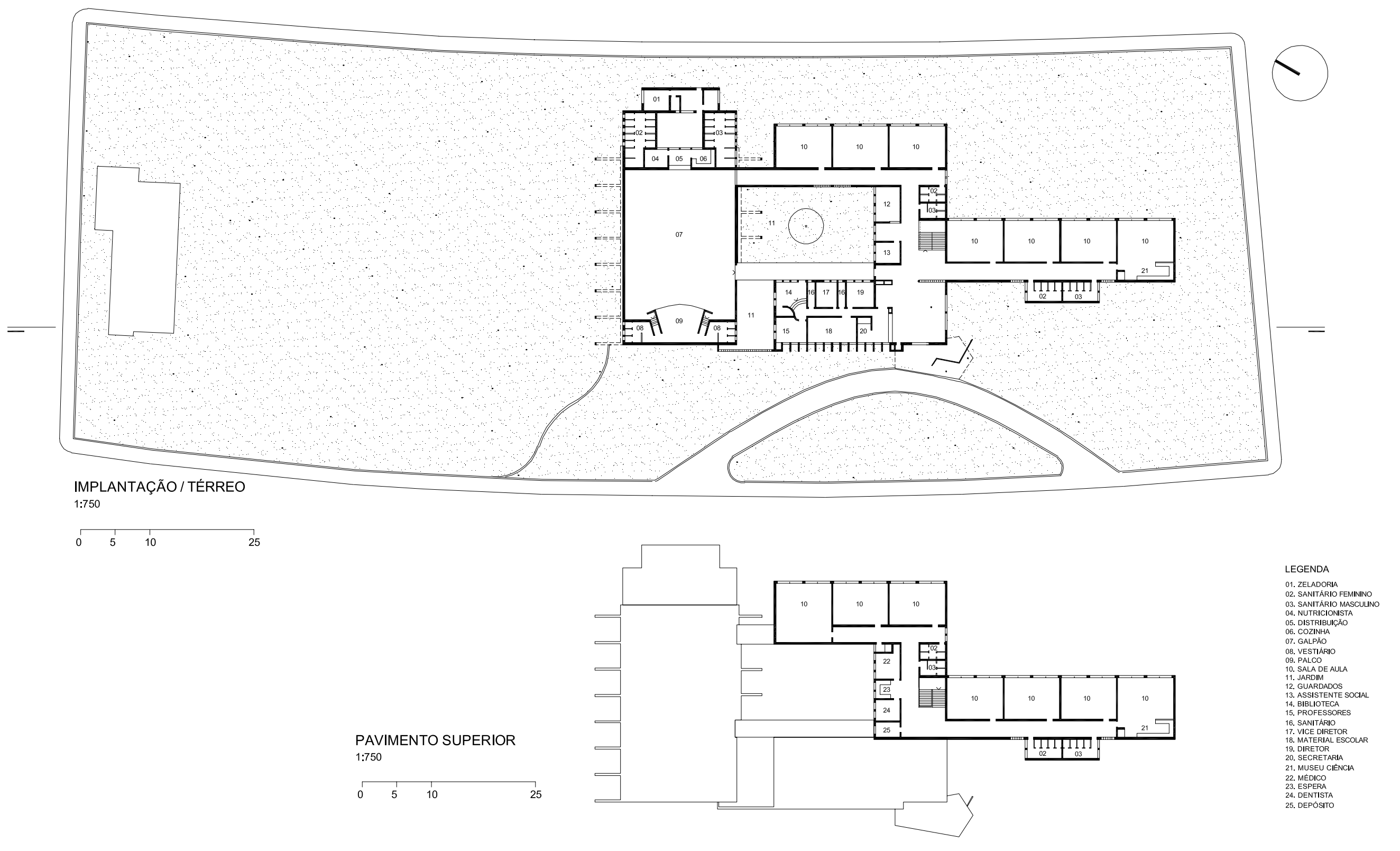




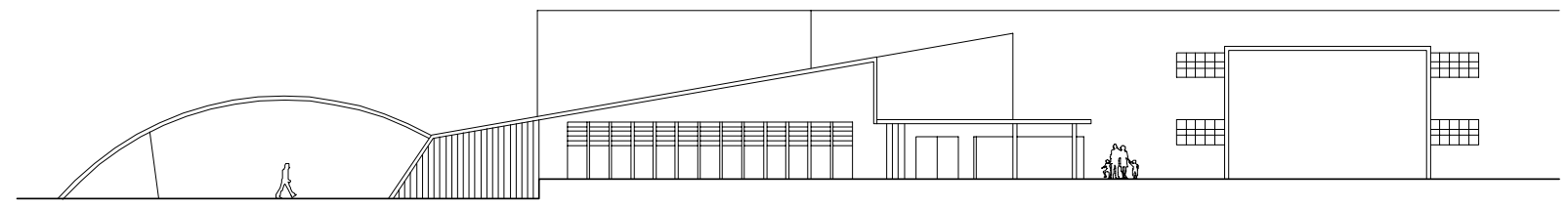

ELEVAÇÃO NOROESTE

1:500

\begin{tabular}{llll}
\hline & 1 & 1 & 20
\end{tabular}

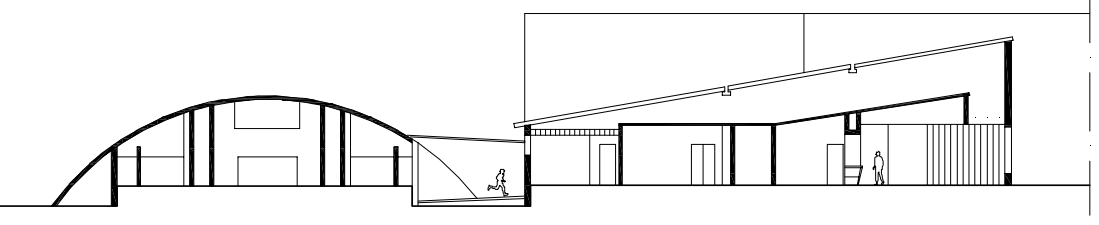

CORTE

1:500

\begin{tabular}{llll}
\hline & 1 & 1 & 20
\end{tabular} 


\section{EE Prudente de Moraes (data não identificada)}

Localizada na Avenida Tiradentes, no bairro do Bom Retiro, essa escola repete a conexão de blocos funcionais independentes organizados a partir de um eixo de circulação paralelo à avenida.

Com volumes conectados lado a lado, o bloco administrativo é térreo, o bloco de recreação é abobadado e o bloco de ensino apresenta-se em 2 pavimentos. Mais uma vez, o arquiteto Hélio Duarte, através de uma marquise e de um pergolado, garante uma transição de escalas entre a rua e o edifício; a calçada em curva encaminha o pedestre para a entrada.

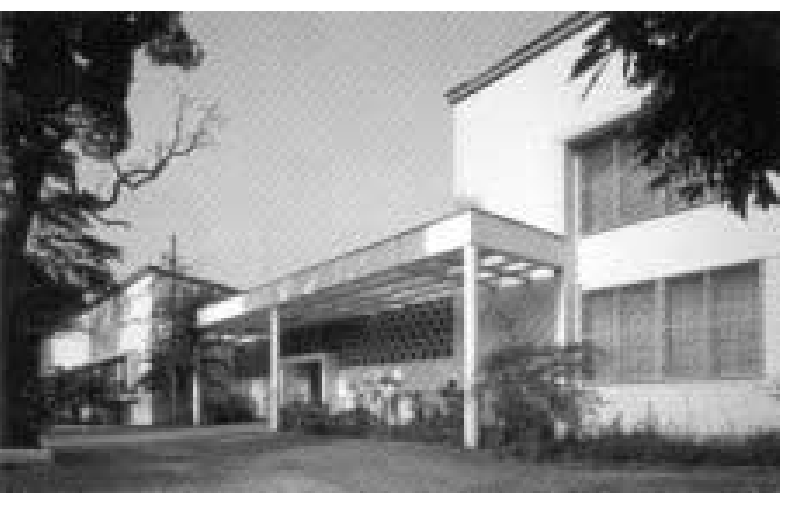

MARQUISE DE ENTRADA MARCA A TRANSIÇ̃̃o ENTRE ESPAÇO URBANO E ESPAÇO DA ESCOLA

Nessa escola, as salas coladas ao muro foram projetadas pelo escritório do arquiteto Ramos de Azevedo. 


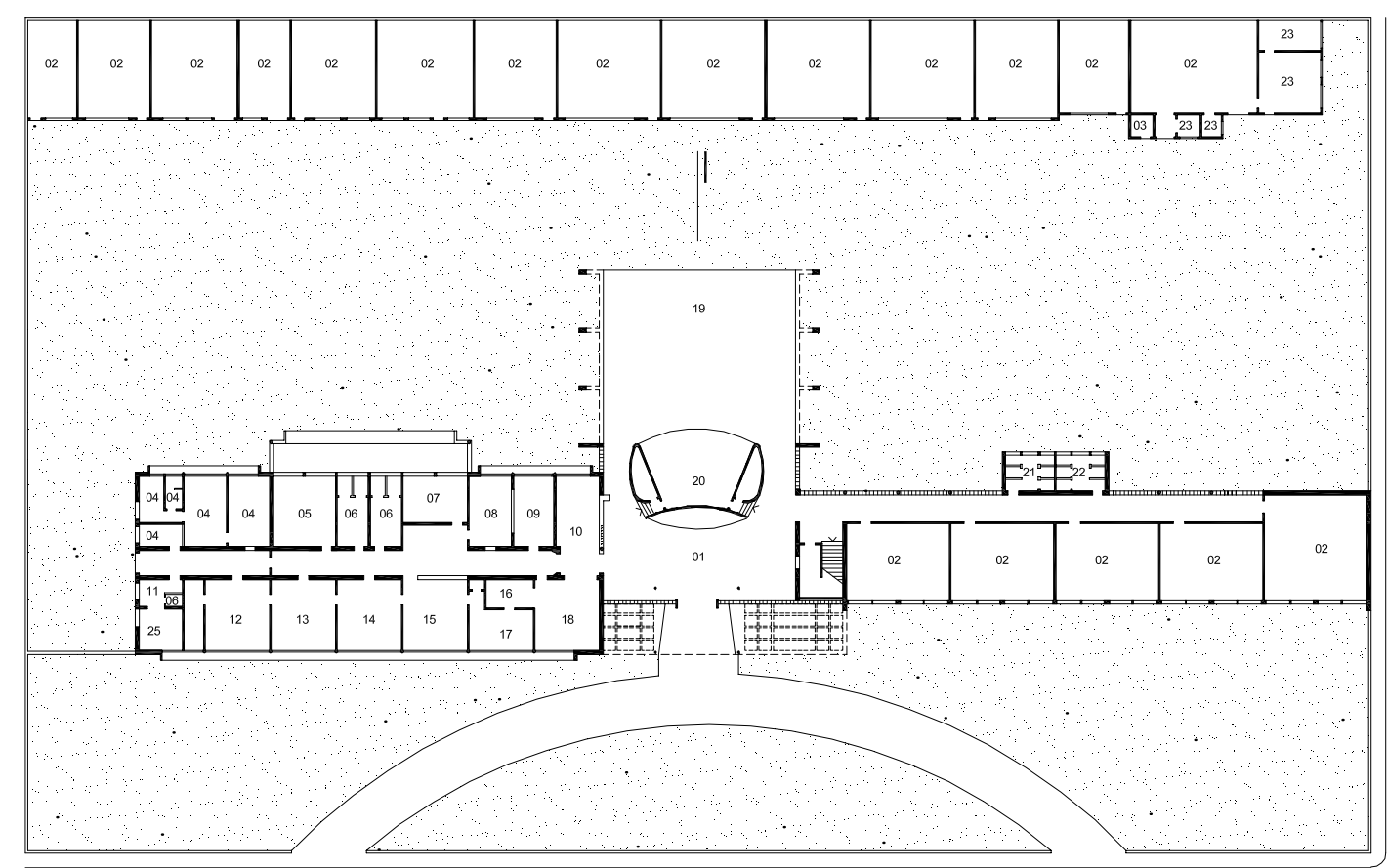

IMPLANTAÇÃO / TÉRREO $1: 750$

\begin{tabular}{llll}
\hline & 1 & 10
\end{tabular}

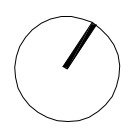

PRIMEIRO PAVIMENTO $1: 750$
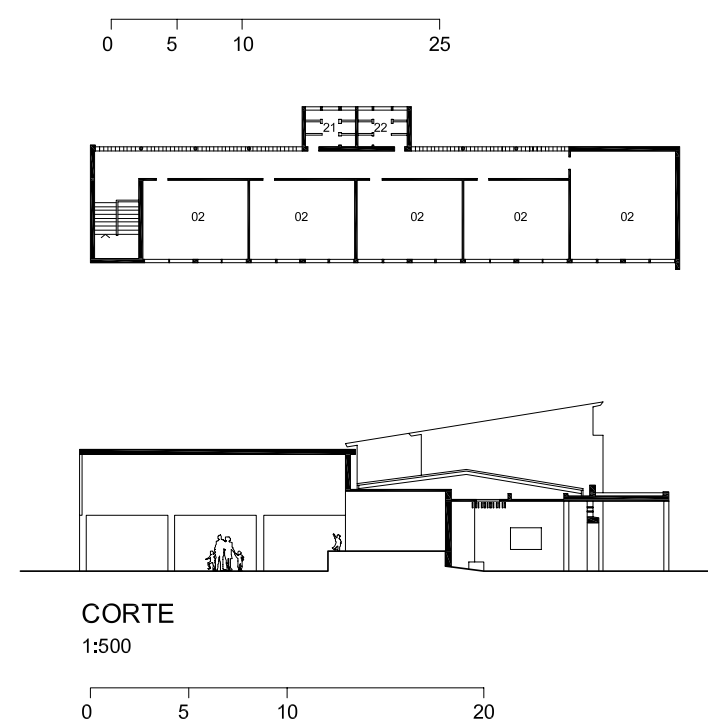

\section{Q}

\section{ELEVAÇÃO SUDESTE}

$1: 500$

\begin{tabular}{llll}
\hline & 1 & 1 & 20
\end{tabular} 


\section{EE Orville Derby (1949)}

Localizada no bairro de Vila Formosa, essa escola caracterizou-se volumetricamente pela articulação ortogonal do bloco administrativo (térreo) e do bloco de ensino (2 pavimentos) com o bloco de recreação (pilotis sob o bloco de ensino) configurando um volume com três pavimentos. A solução de recreio coberto por pilotis é justificada pelo desnível existente no terreno.

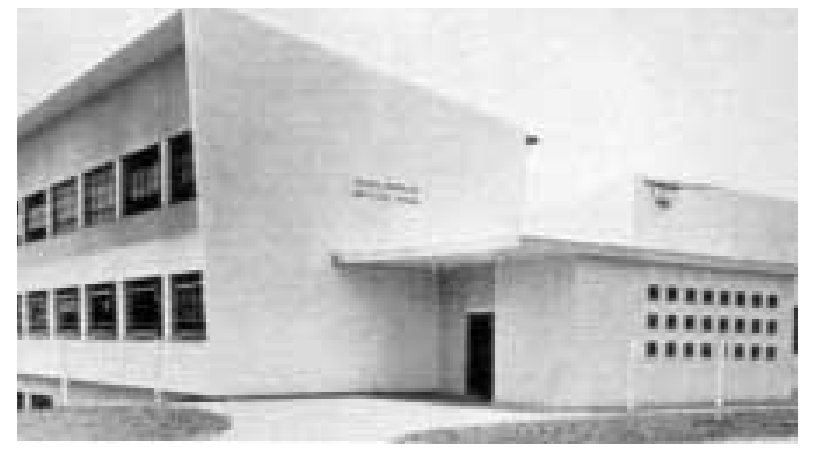

A MARQUISE DE ENTRADA SE REPETE EM TODOS OS PROJETOS DE HÉLIO DUARTE PARA 0 CONVÊNIO 

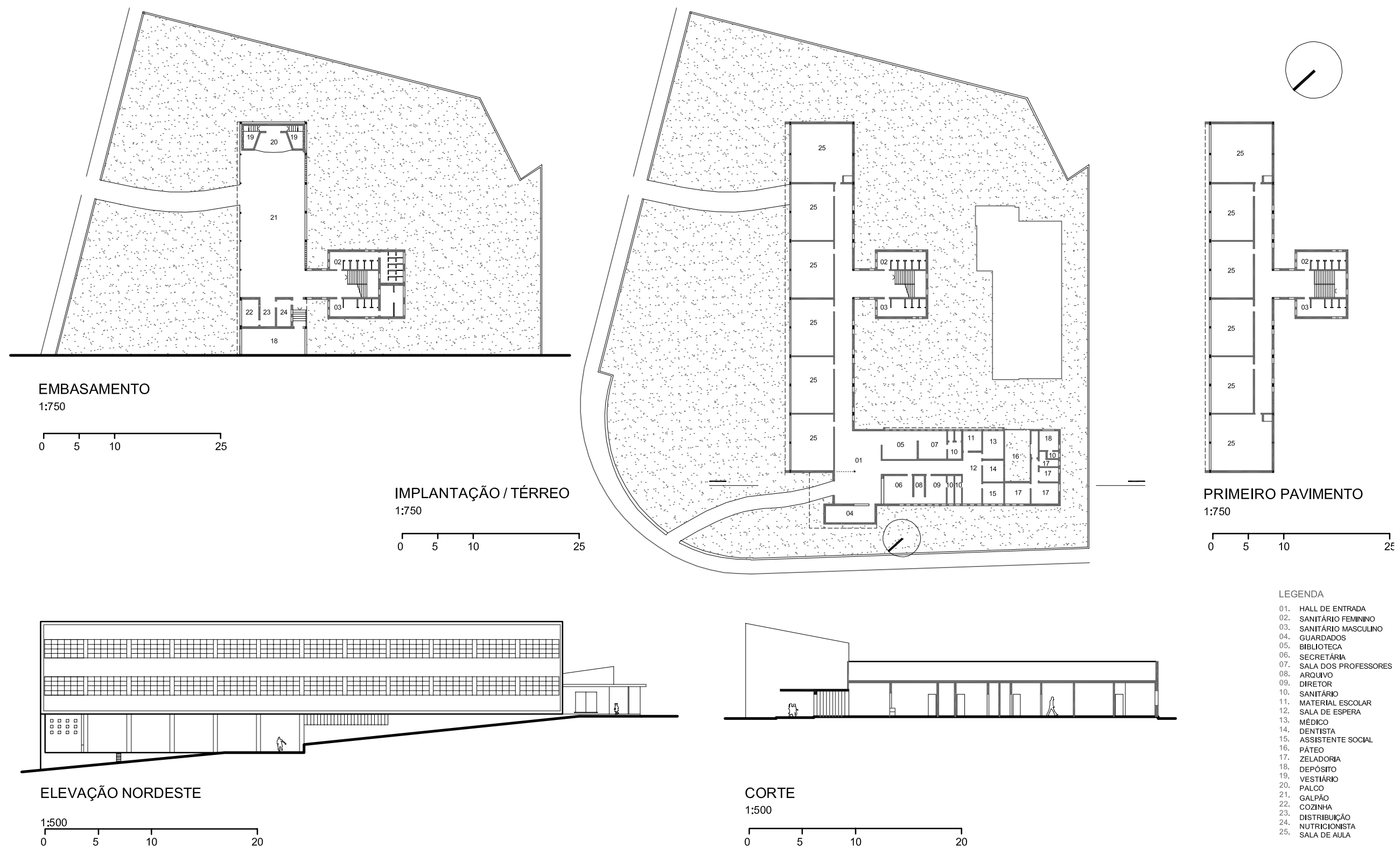


\section{EE Brasílio Machado (1950)}

Localizada no bairro de Vila Madalena, nessa escola, em função do reduzido tamanho do terreno para o programa solicitado, optou-se pelo pilotis como solução para o recreio coberto. Seu edifício apresenta-se com uma implantação em "U', que abraça o pátio descoberto da escola, criando uma escala adequada às crianças em suas atividades recreativas. $\bigcirc$ pátio possibilita, também, a entrada de luz nordeste em todas as salas de aula.

As salas de aula localizam-se no pavimento superior dos blocos paralelos à rua, e o arquiteto diferencia, na forma dos volumes, o bloco ortogonal à rua, deixandoo mais baixo e explicitando sua função de conexão.

O edifício está em cota elevada em relação à rua e a marquise de entrada, desortogonalizada, cobre o final da rampa sinuosa, desenhada em continuidade à calçada existente.

Esse projeto revela a coerência da arquitetura praticada pelos arquitetos do convênio ao não impor uma tipologia padrão, e sim adequar a solução arquitetônica às questões propostas pelo lugar.

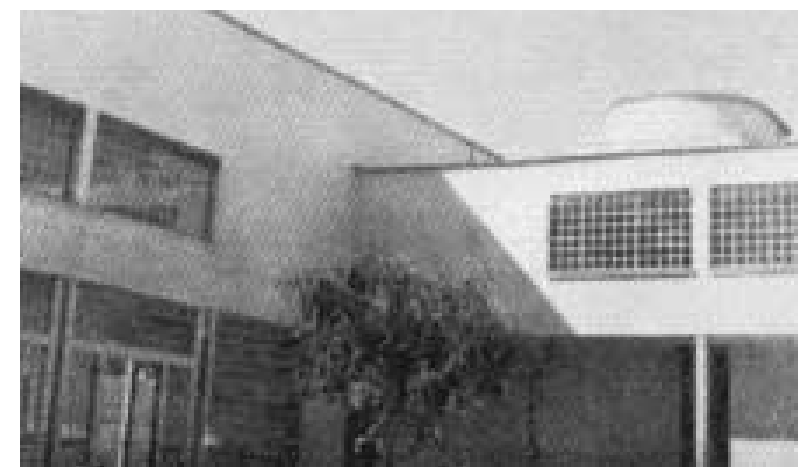

TRANSIC̣̃̃O ENTRE BLOCOS RESOLVIDA ATRAVÉS DE VOLUME MAIS BAIXO

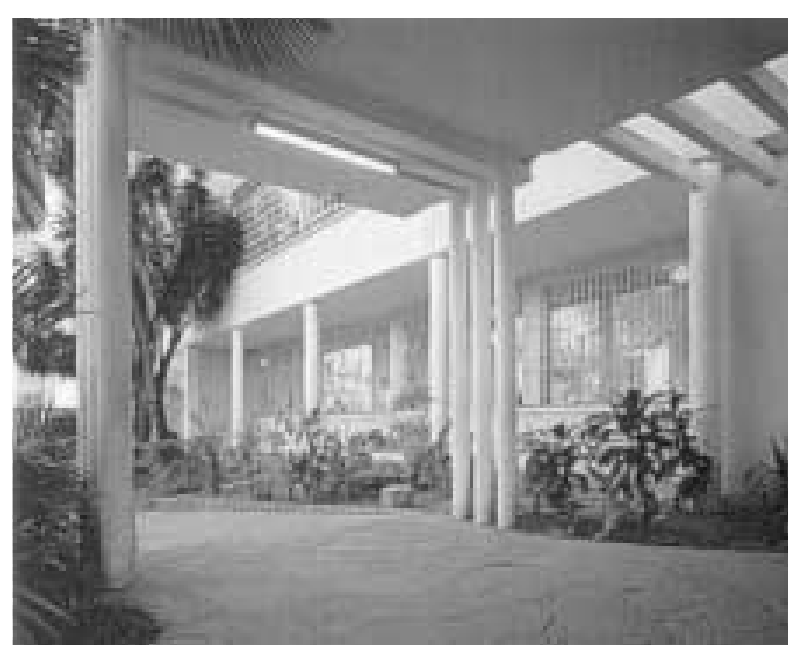

MARQUISE DE ENTRADA ACOLHE A CRIANÇA 


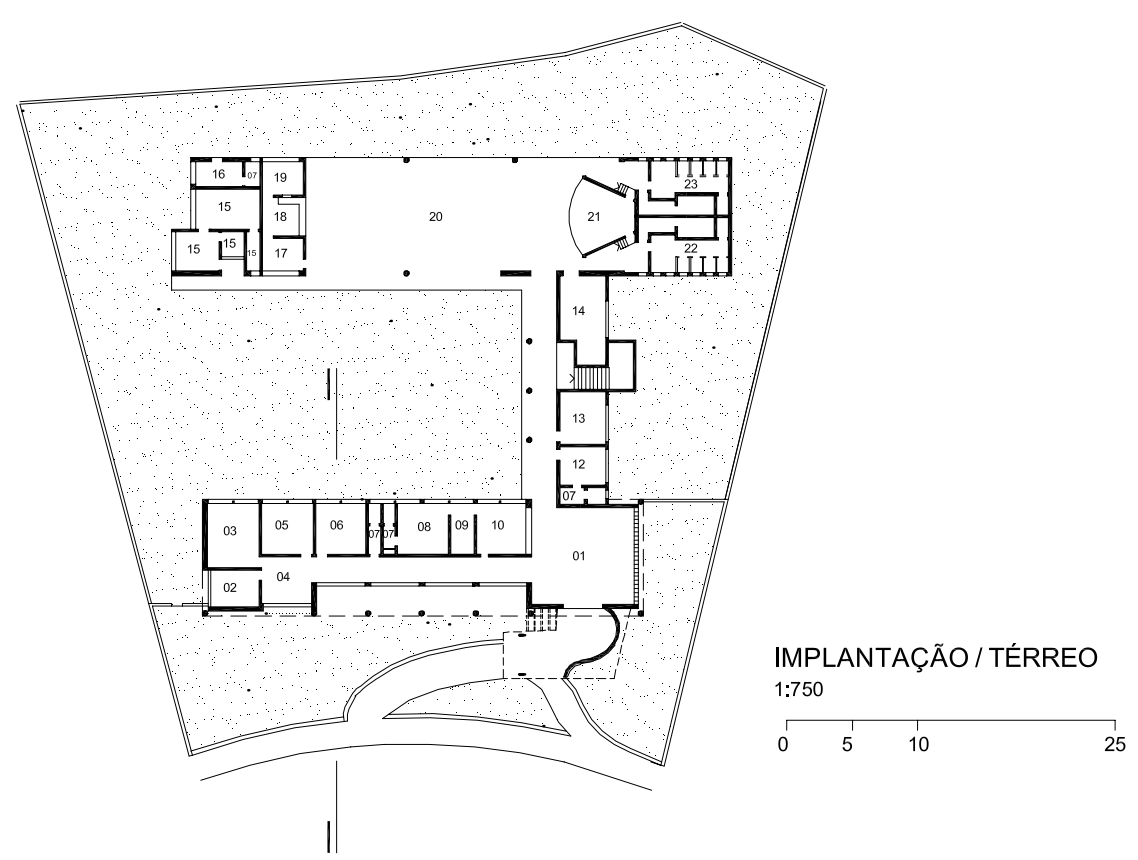

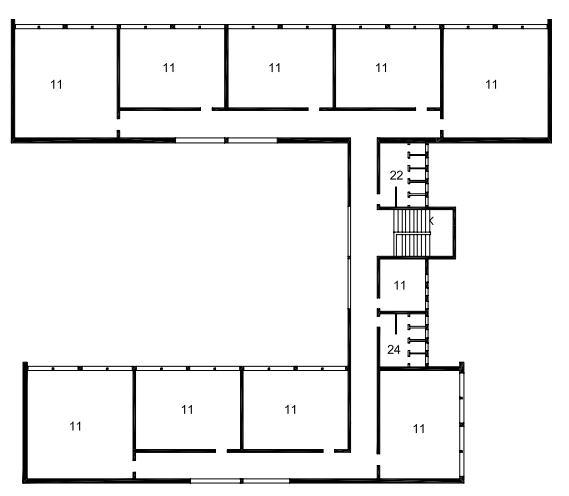

PRIMEIRO PAVIMENTO 1:750

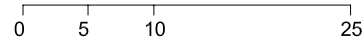

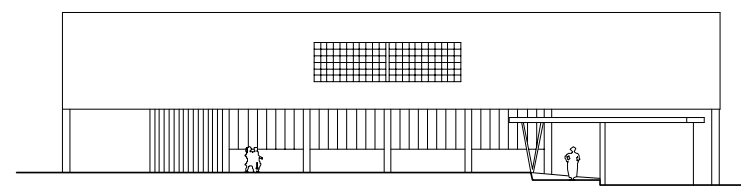

ELEVAÇÃO SUL

1:500

\begin{tabular}{llll}
\hline & 5 & 10 & 20
\end{tabular}

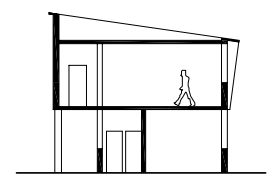

CORTE

1:500

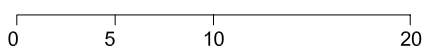

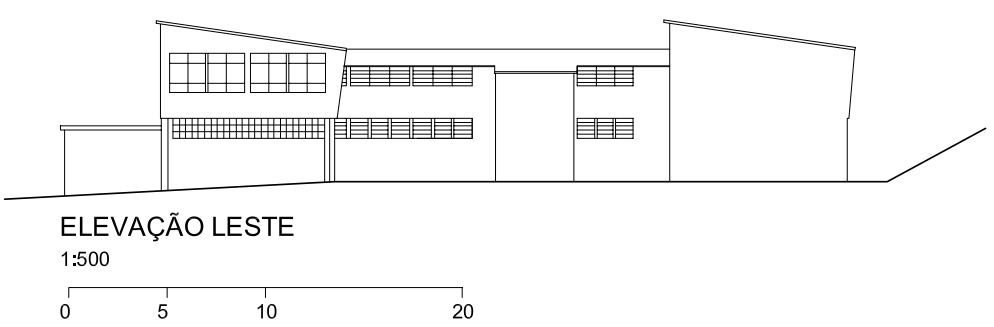

LEGENDA

01. HALL DE ENTRADA
02. ASSISTENTE SOCIAL

03. MSDDICO
04. SALA DE ESPERA

D. DENTISTA ESCOAA

7. SANTARIO
8. DRETTRAA

ARQUUVO
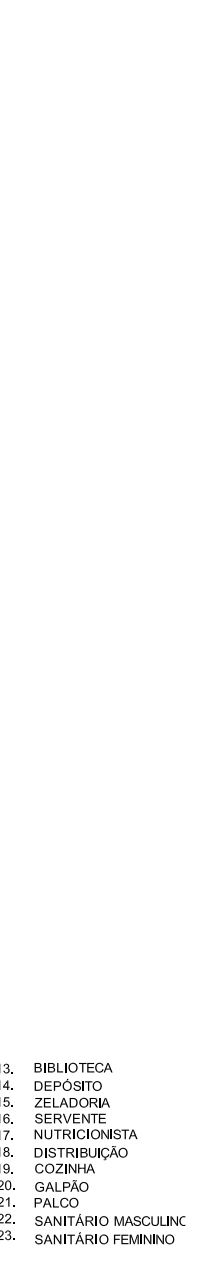


\section{ARQUITETO EDUARDO CORONA}

Seus projetos se destacaram, no conjunto das obras do convênio, pelo cuidado com a plástica e pela elaboração de detalhes construtivos. Do conjunto das seis escolas, projetadas entre os anos de 1950 e 1952, o uso da cobertura em asa de borboleta caracterizou a arquitetura de quatro delas. Todas as escolas foram implantadas a partir da articulação de blocos funcionais independentes e conectados, em sua maioria, com a continuidade das coberturas dos blocos, o que difere das passagens cobertas, que caracterizaram a articulação entre blocos típicos das demais obras do convênio.

O arquiteto Eduardo Corona, em depoimento publicado na tese de doutorado de Mário Henrique de Castro Caldeira, colocou que o arquiteto Hélio Duarte coordenava os projetos, mas garantia liberdade de criação à sua equipe, o que possibilitava a expressão individual de seus componentes, desde que dentro das diretrizes estabelecidas.

Em seus depoimentos, revelou algumas discordâncias quanto à economia sempre priorizada pelo arquiteto Hélio Duarte na elaboração dos projetos para o convênio - dizia que uma obra econômica poderia reverter, anos depois, em altos custos de manutenção e que projetos, com custos mais baixos, desde sua concepção, poderiam gerar problemas nos edifícios em construção, devido à pouca qualidade das obras públicas executadas pelas empreiteiras que venciam as licitações.

Seguem as escolas projetadas pelo arquiteto Eduardo Corona: 


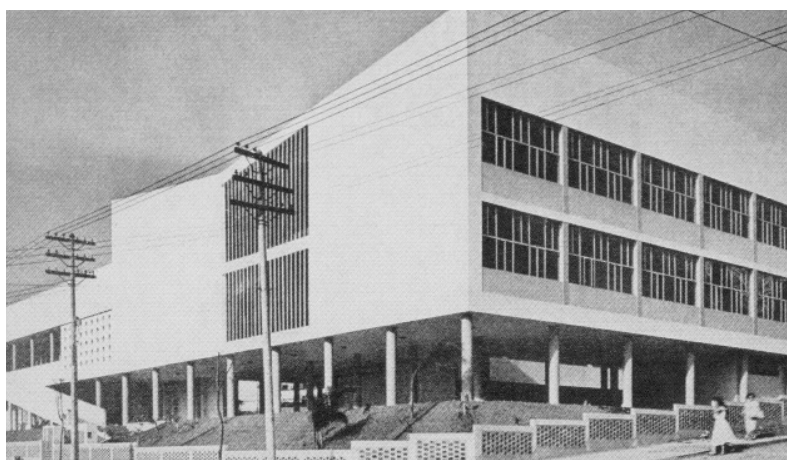

EDIFÍCIO DE GRANDE PORTE COM COBERTURA EM ASA DE BORBOLETA GANHA LEVEZA ATRAVÉS DO USO DO PILOTIS

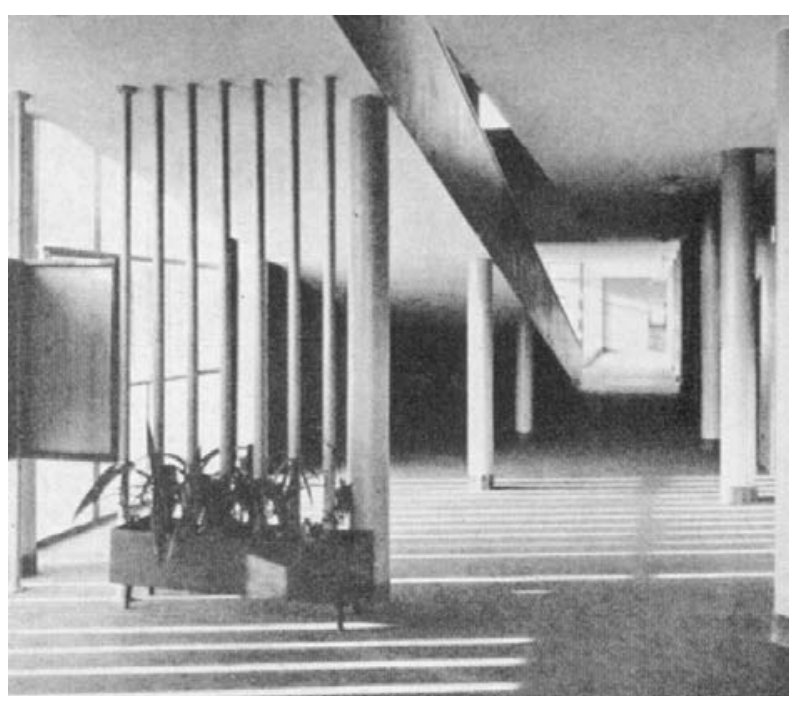

DETALHES MAIS ELABORADOS CARACTERIZARAM A OBRA DE EDUARDO CORONA

\section{EE Nossa Senhora da Penha (1951)}

Localizada no bairro do Tatuapé, esse edifício escolar comprova o apuro estético do arquiteto, sua principal característica. Tombada pelo Conselho de Defesa do Patrimônio Histórico, Arqueológico, Artístico e Turístico do Estado de São Paulo (CONDHEPHAT), está atualmente em processo de restauro. É considerada por críticos de arquitetura um dos exemplares mais elegantes da arquitetura escolar brasileira.

O edifício escolar contempla em seu programa, além do programa básico, auditório, piscina, laboratórios e salas ambientes para disciplinas específicas. Seus ambientes são organizados a partir de um pátio central, que garante iluminação nordeste para todas as salas de aula. Esse bloco em " $U$ " de 3 pavimentos, definido pelo pátio, articula-se com o bloco do auditório, através de um volume em 2 pavimentos; sob esses dois blocos é configurado um pavimento em pilotis, onde está localizado o recreio coberto, que garante fluidez na circulação entre os espaços cobertos e descobertos, o que vem de encontro à mobilidade infantil, tão prezada pelos arquitetos do convênio. No volume em " $U$ ", a cobertura em asa de borboleta é conectada ao volume reto, com cobertura em uma água e que faz a conexão com o anfiteatro. Sua circulação vertical apresenta, além das caixas de escada, solução em rampas que chegam até a cota da calçada - as rampas passaram a ser implantadas em várias escolas do convênio escolar. 


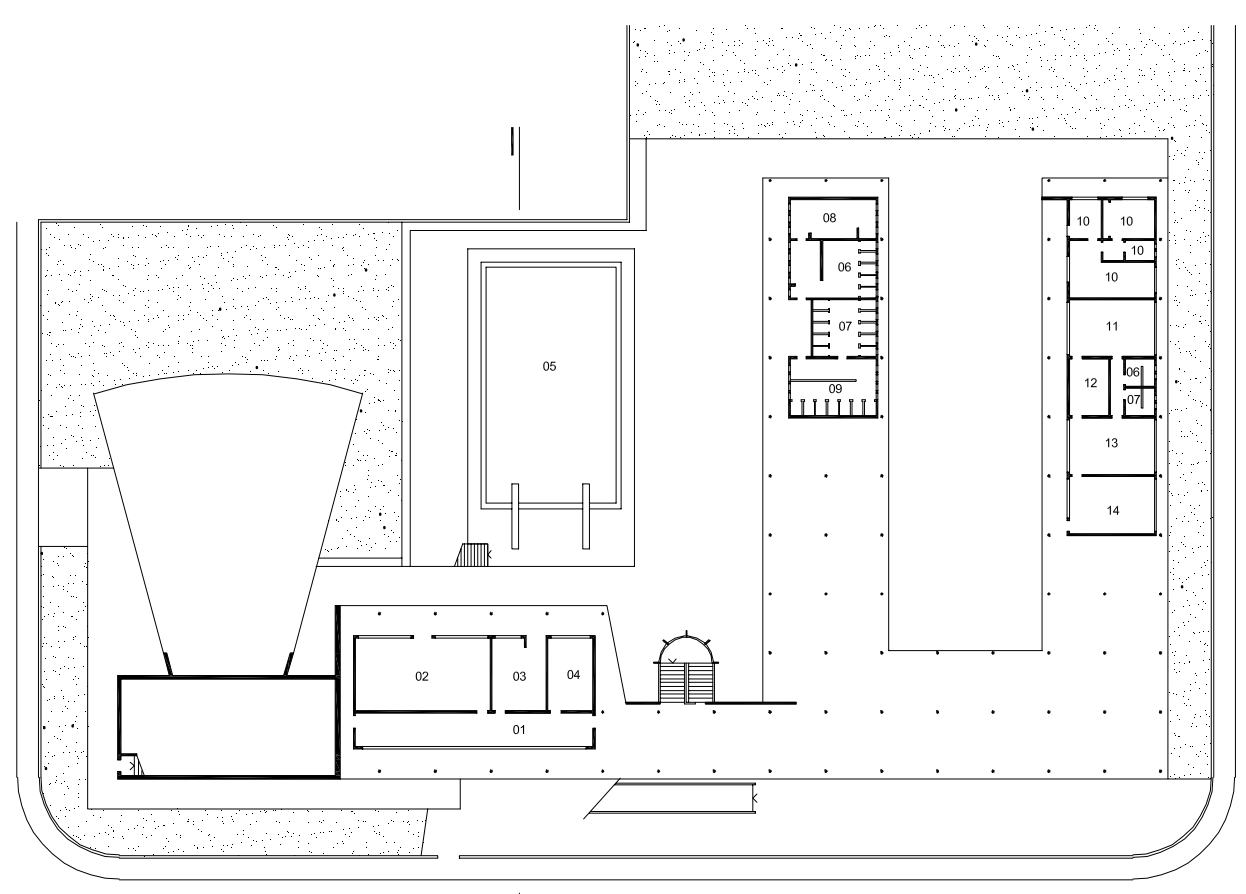

IMPLANTAÇÃO / TÉRREO 1:750

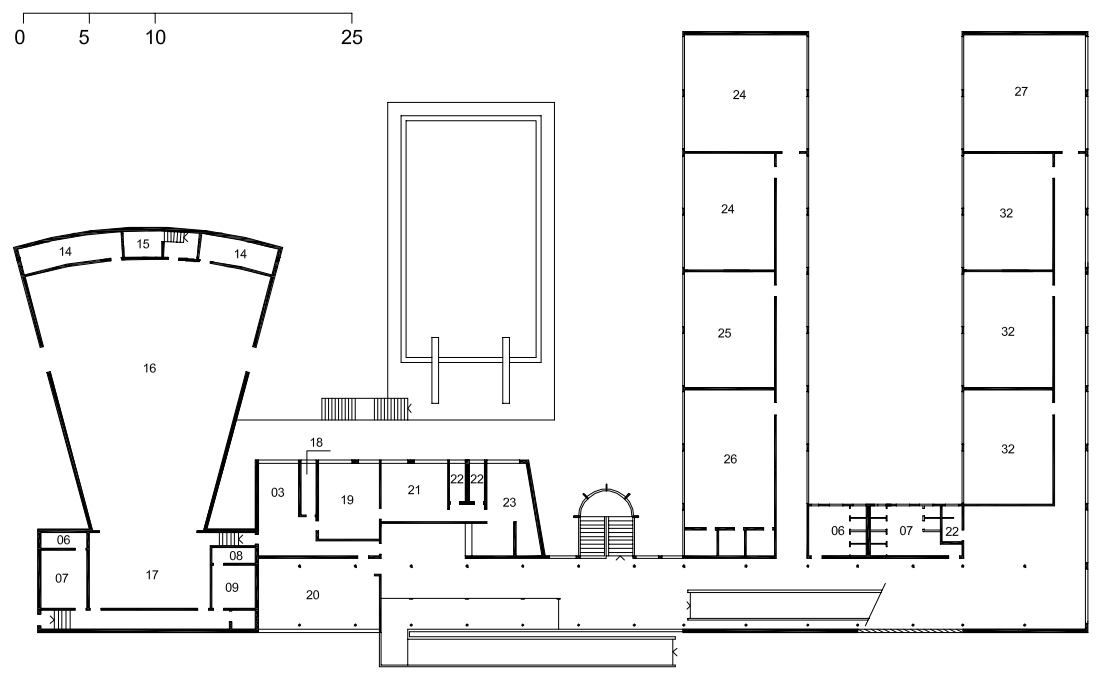

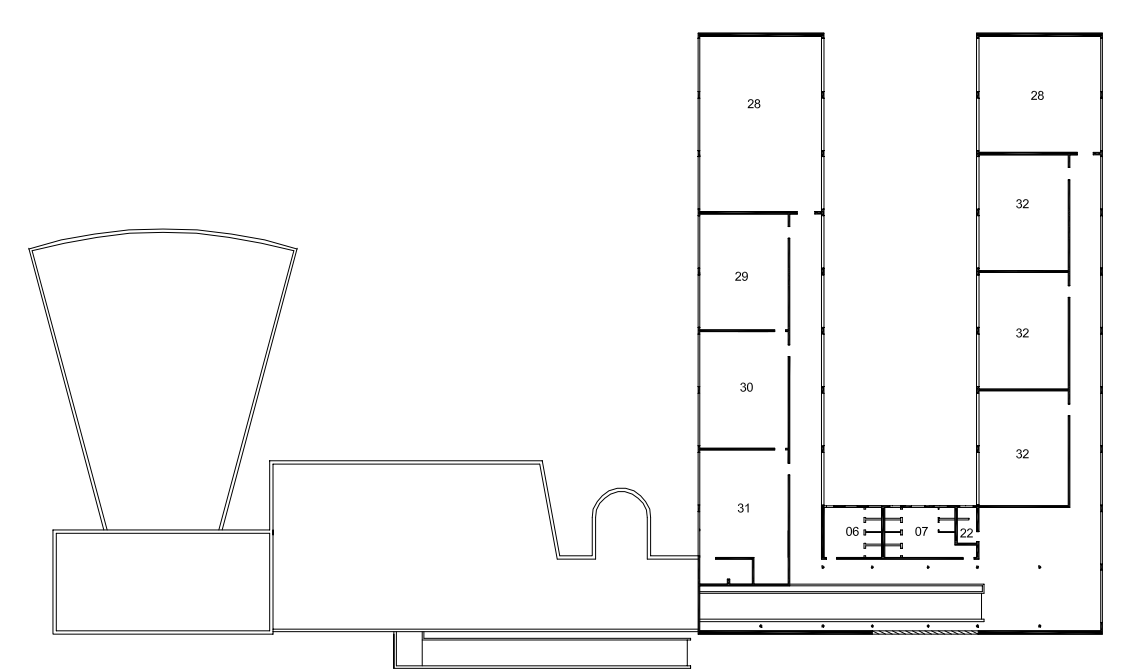

SEGUNDO PAVIMENTO

1:750

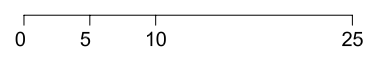

PRIMEIRO PAVIMENTO 1:750

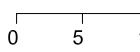

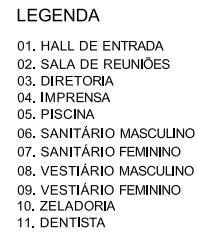

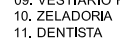

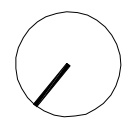

12. SALA DE ESPERA

13. MELDICO
14. DEPÓSITO

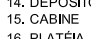

17. PALCO

18. SANITARRIO
19. SALA DE CONGREGAÇĀO 21. SALA DOS PROFESSORES
22. SANITARIO

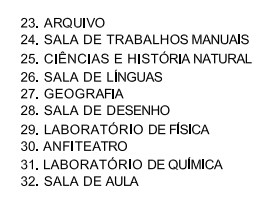



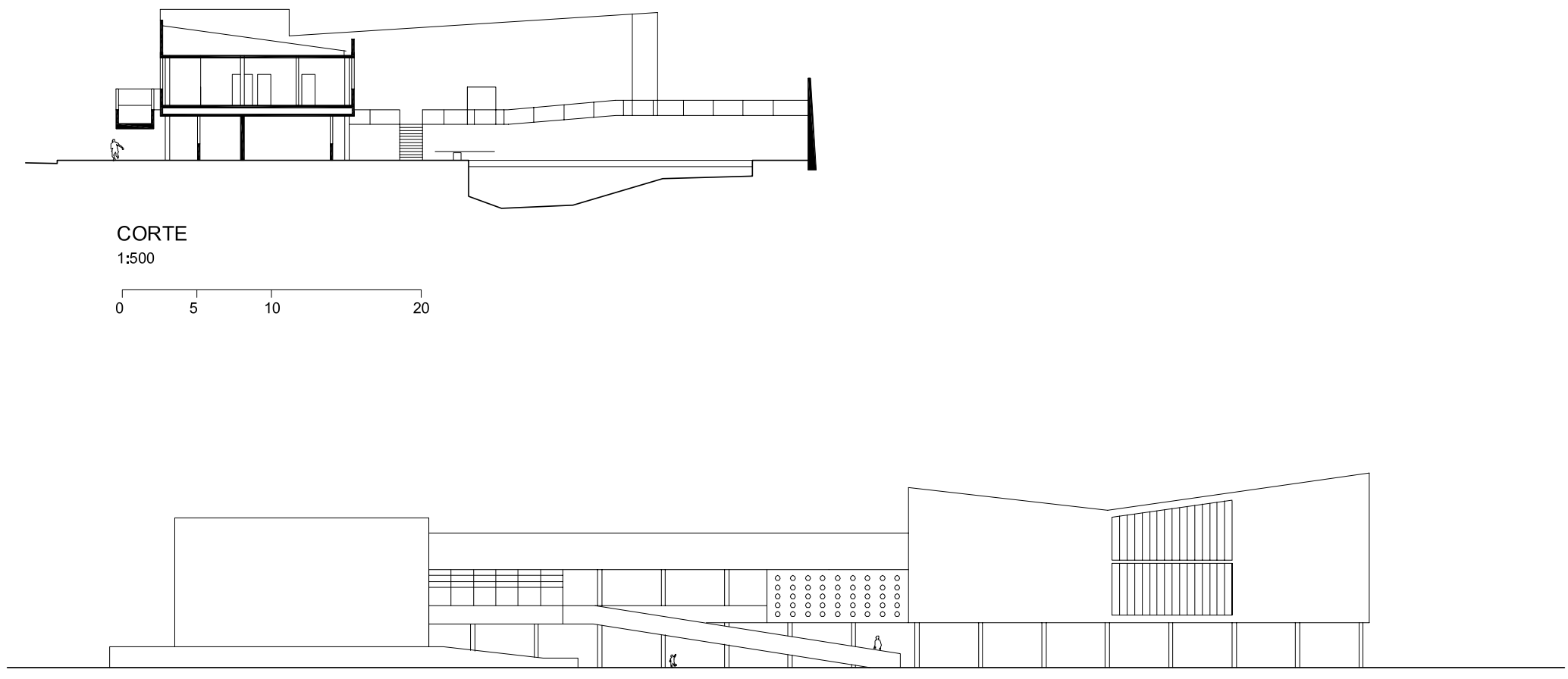

ELEVAÇÃO NOROESTE

1:500

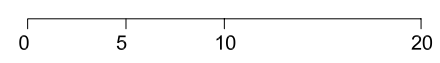




\section{EE Erasmo Braga (1950)}

Localiza-se no bairro de Tatuapé. A continuidade de sua cobertura em asa de borboleta conecta o bloco administrativo térreo ao bloco de ensino de 2 pavimentos, e o bloco de ensino, por sua vez, apóia-se sobre o pilotis do recreio coberto. A opção pelo pilotis foi decorrência natural da situação topográfica existente.

A solução da cobertura em asa de borboleta, elegante em suas proporções, lembra a corbusiana casa Errazuris, que influenciou Niemeyer na solução para a cobertura da casa de Juscelino Kubischek e o iate clube de Pampulha.

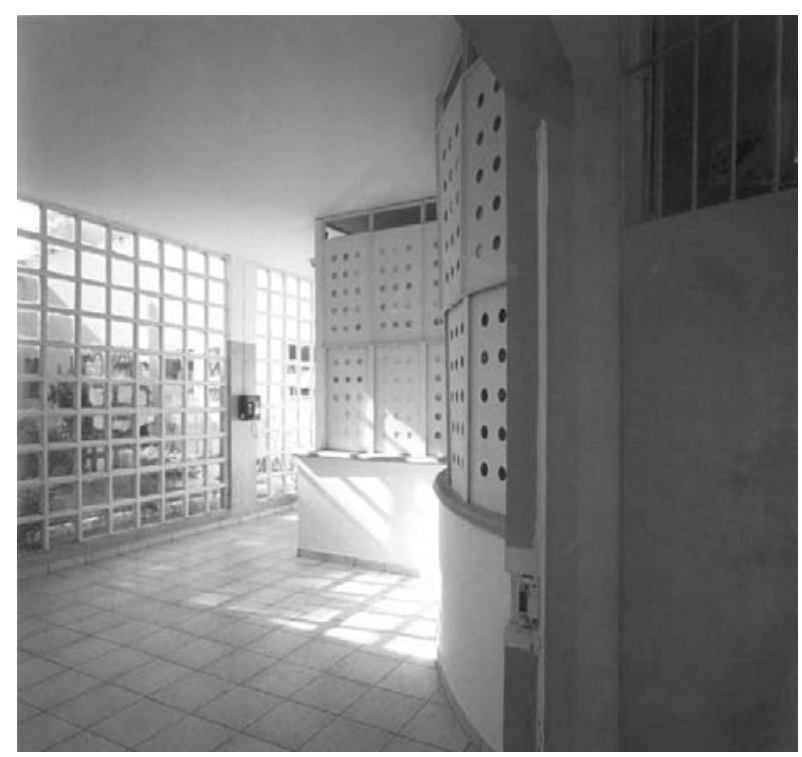

ACESSO À BIBLIOTECA E SALAS DE PROFESSORES 


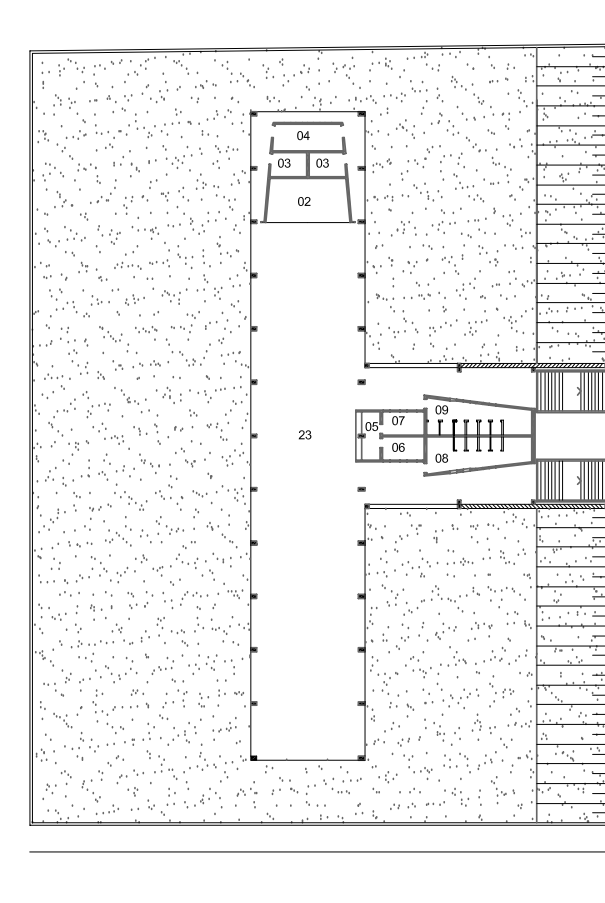

PAVIMENTO TÉRREO

1:750

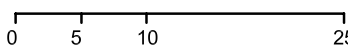

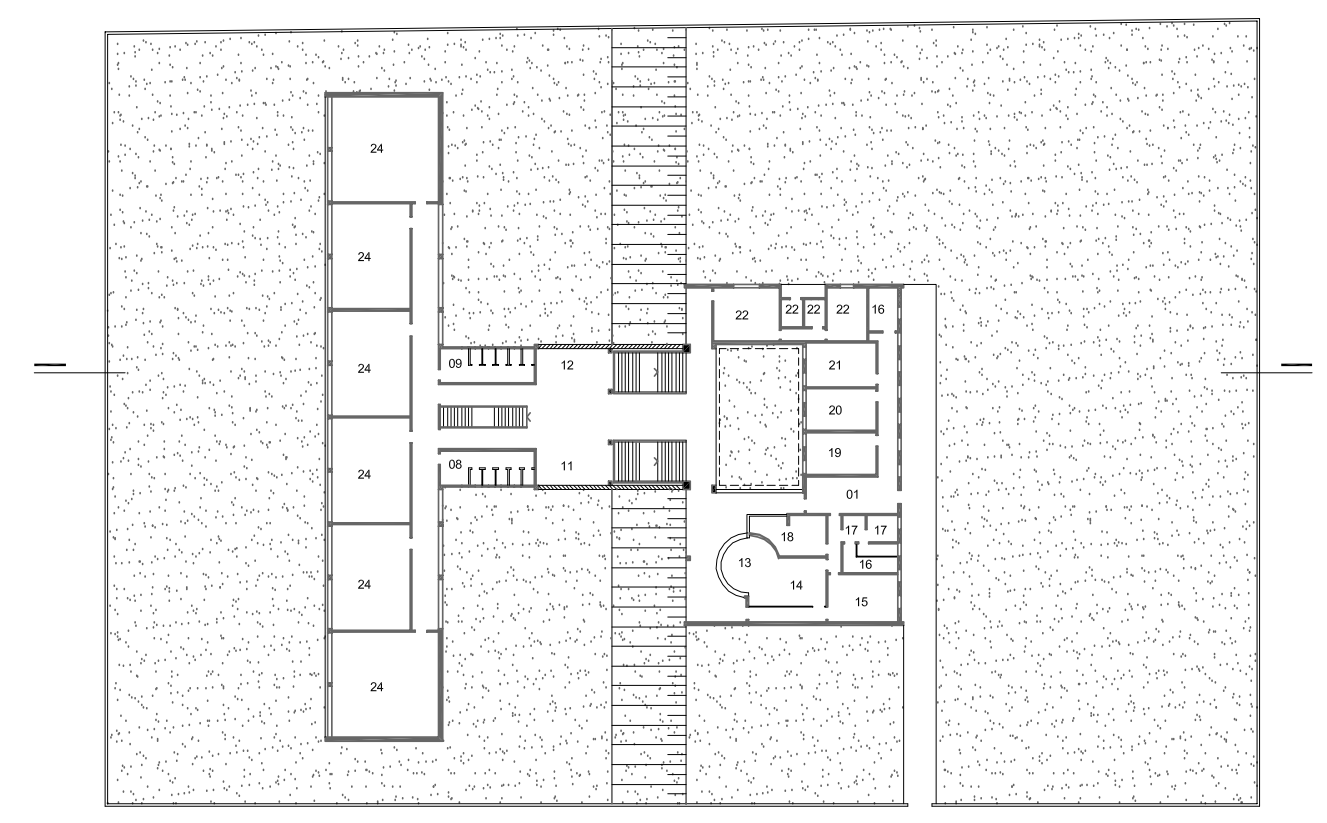

IMPLANTAÇÃO / PRIMEIRO PAVIMENTO 1:750

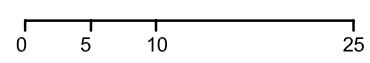

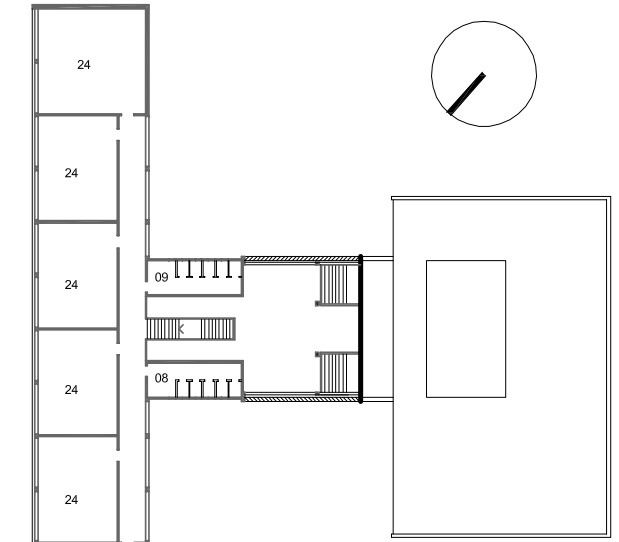

SEGUNDO PAVIMENTO 1:750

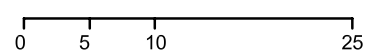

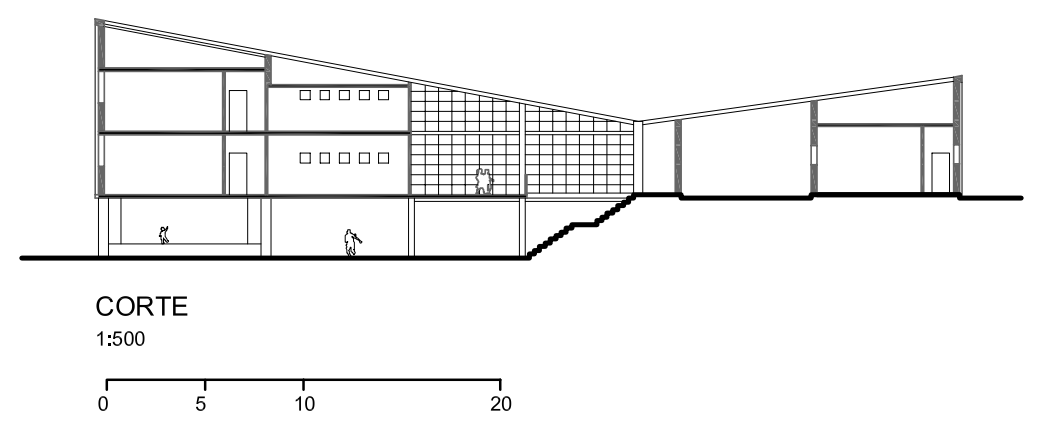
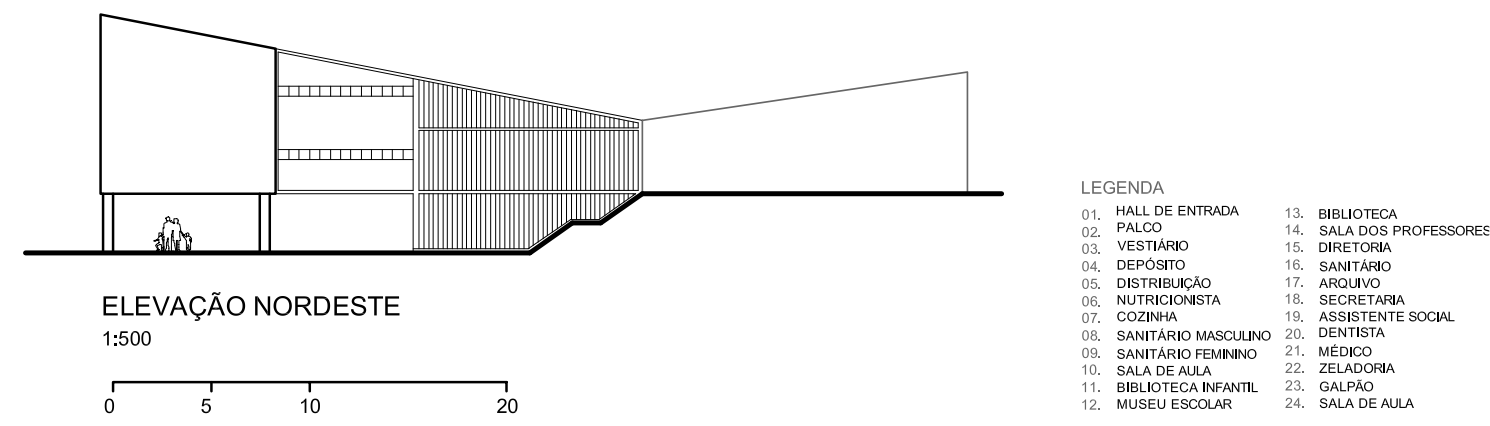


\section{EE Doutor Reinaldo Ribeiro da Silva (1950)}

Localiza-se no bairro da Lapa e repete a solução da cobertura em asa de borboleta, que conecta os blocos de ensino de 2 pavimentos ao bloco de recreação. Neste caso, o recreio coberto está conformado por um pé-direito duplo. $\bigcirc$ bloco administrativo, térreo com pequenas e econômicas aberturas, conecta-se ao conjunto em asa de borboleta, através de uma singela marquise que serve de passagem coberta. 


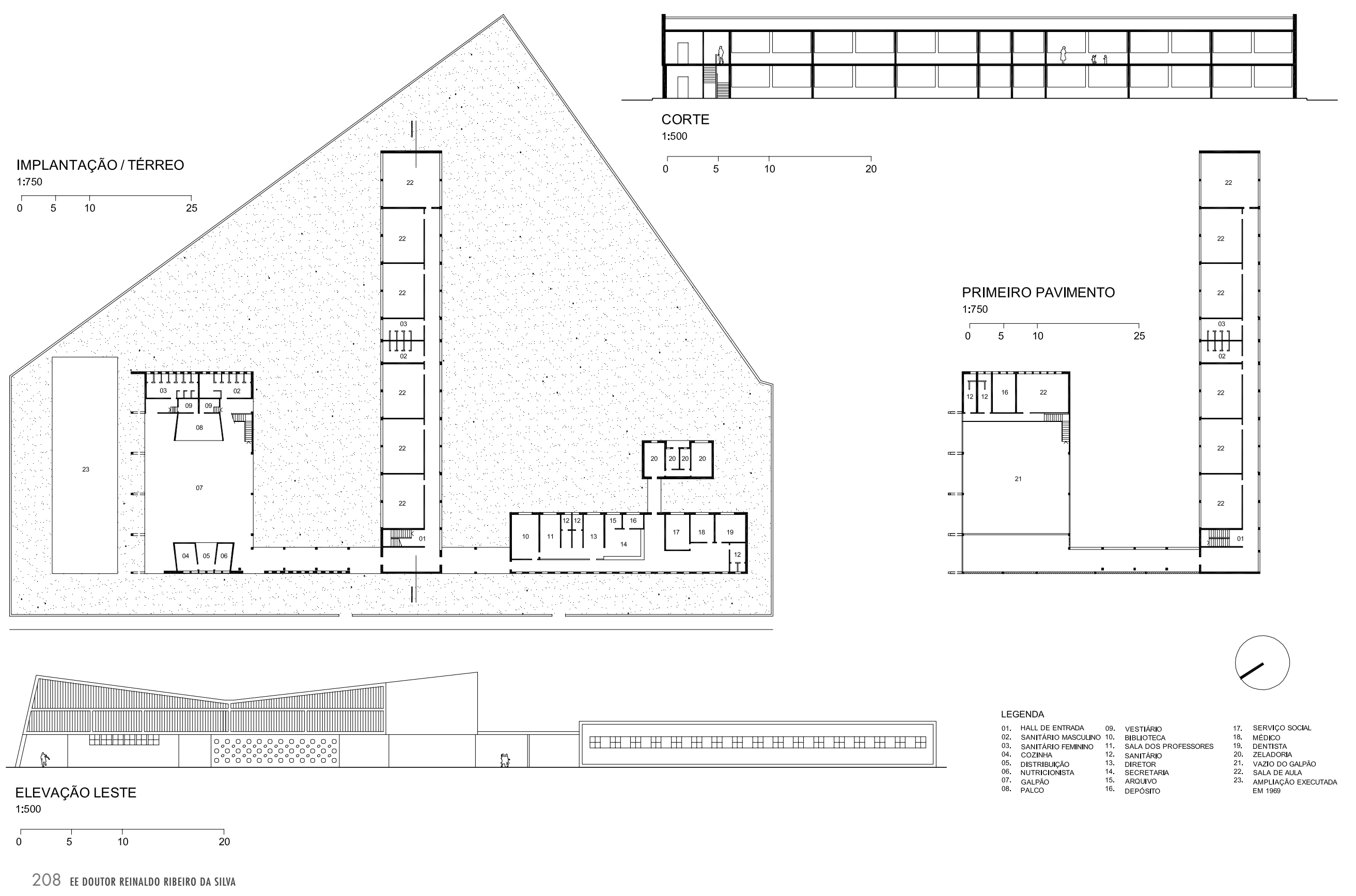




\section{EE Pedro Alexandrino (1950)}

Localiza-se no Bairro do Tucuruvi e repete a solução das escolas anteriores, ao conectar o bloco de ensino, de 2 pavimentos, ao bloco administrativo, também em 2 pavimentos, através do desenho da cobertura em asa de borboleta. $O$ aproveitamento inteligente da situação topográfica existente possibilitou a econômica solução do recreio coberto em pilotis sob o bloco administrativo em nível com a rua. 


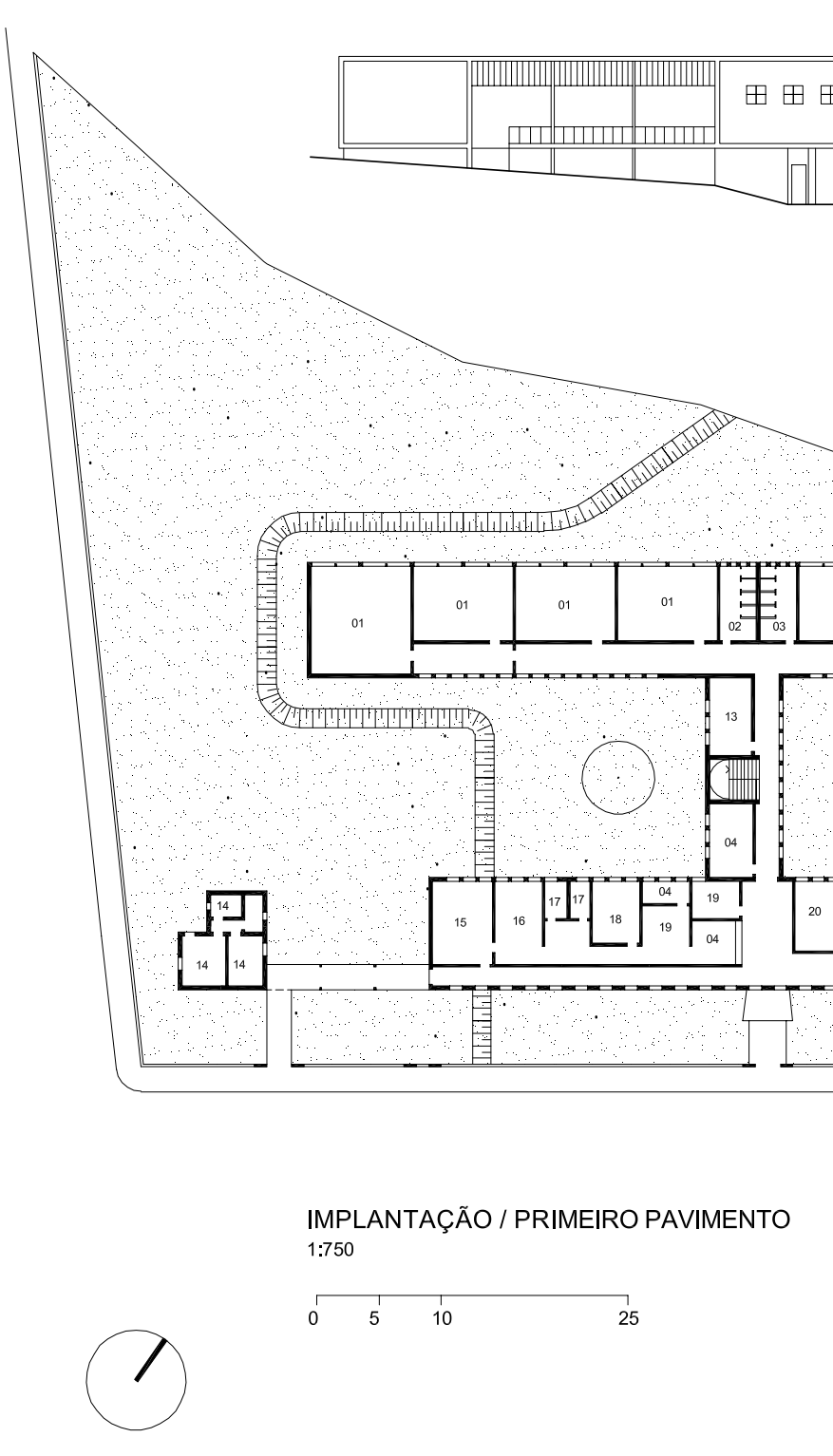

Sones

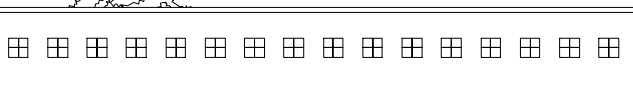

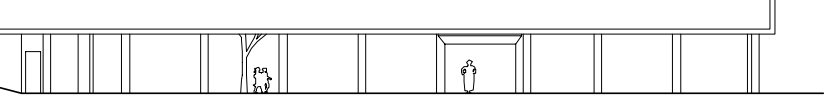

ELEVAÇÃO NORDESTE

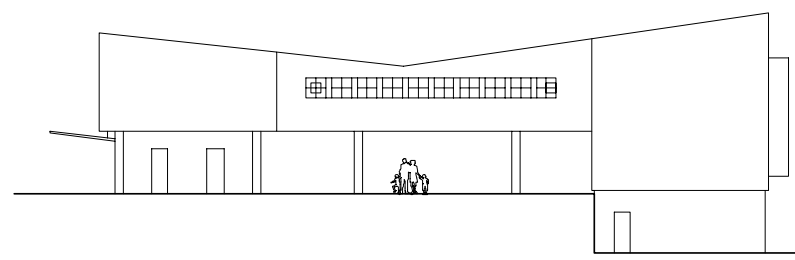

ELEVAÇÃO NOROESTE

1:500

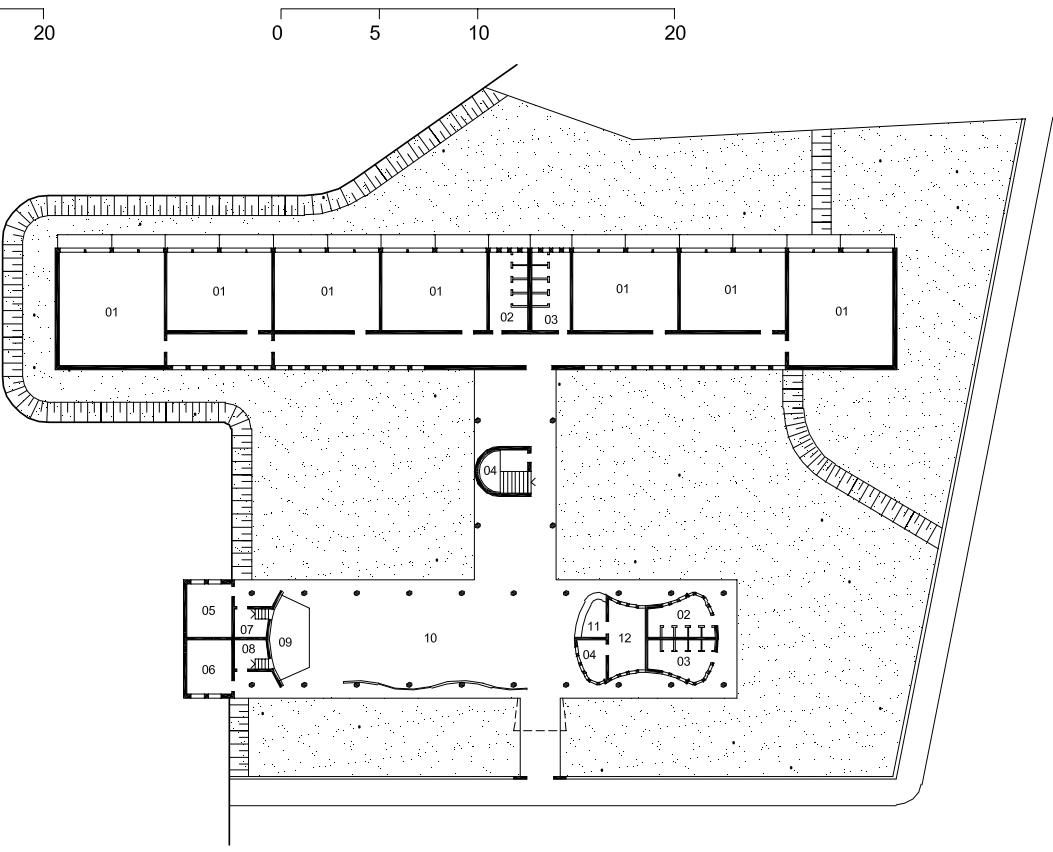

PAVIMENTO TÉRREO

$1: 750$
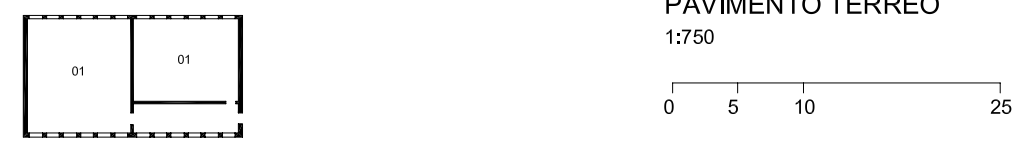

LEGENDA

$\begin{array}{ll}\text { 01. SALA DE AULA } & \text { 12. COZINHA } \\ \text { 02 SANITARIO FEMIIINO } & \text { 13. DESPENA }\end{array}$

03. SAATIARIO MASCULINO

05. SALA DE EDUCACĀO FISICA

O7. V. VESTARIO MASCULINO
OB. VESTIARIO FEMININO

09. PALCO
10. AUDOTORIO
11. CANTINA

12. COZINHA
13. DESEENA
14. ZELAADRAA
15. SECRETARIA

15. SECRETARIA
16. BIBLIITECA
17. SANITARIO

18. DIRETRRA
19. AALA AE LETURA
20. SALA DOS PROFESSORES

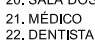

PAVIMENTO INFERIOR 1:750 


\section{Diretoria de Ensino - Região Centro Oeste (1951)}

Localiza-se no bairro de Perdizes em terreno com topografia acidentada, o que permitiu a disposição do recreio coberto sob o pilotis, no qual se apoiam os blocos de salas de aula. Volumetricamente, é composta por dois blocos de 2 pavimentos que se sobrepõem, ortogonalmente, ao bloco administrativo térreo. 


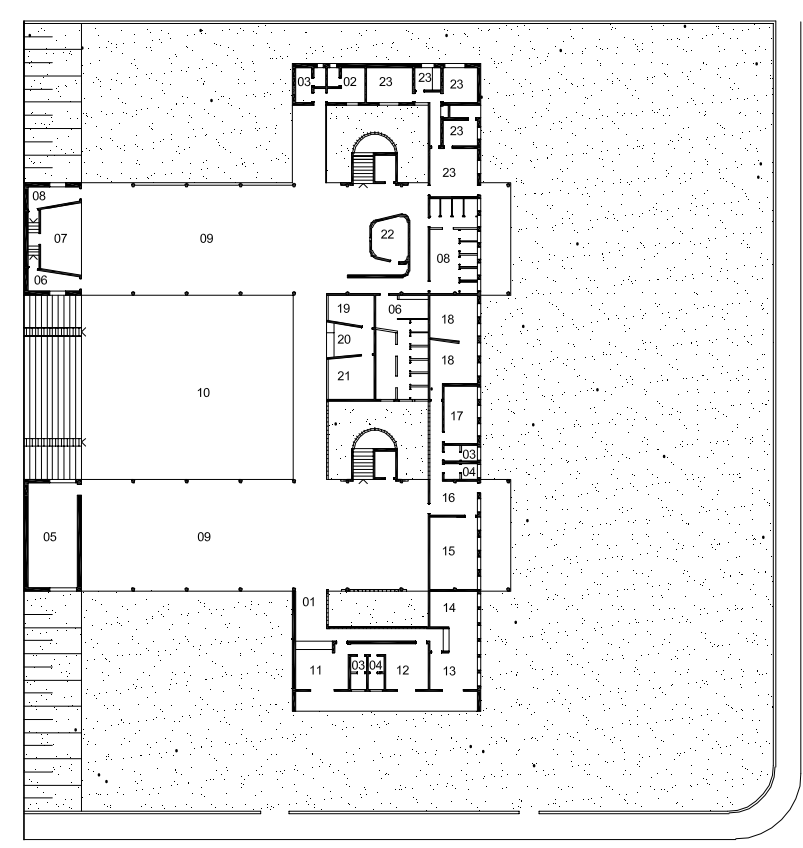

PAVIMENTO TÉRREO

$1: 750$

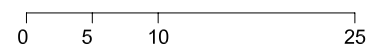

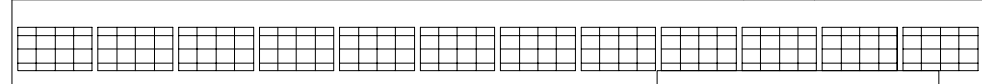

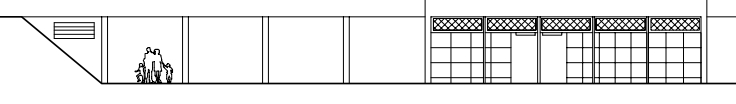

ELEVAÇÃO NORDESTE

1:500

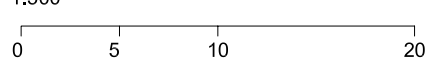

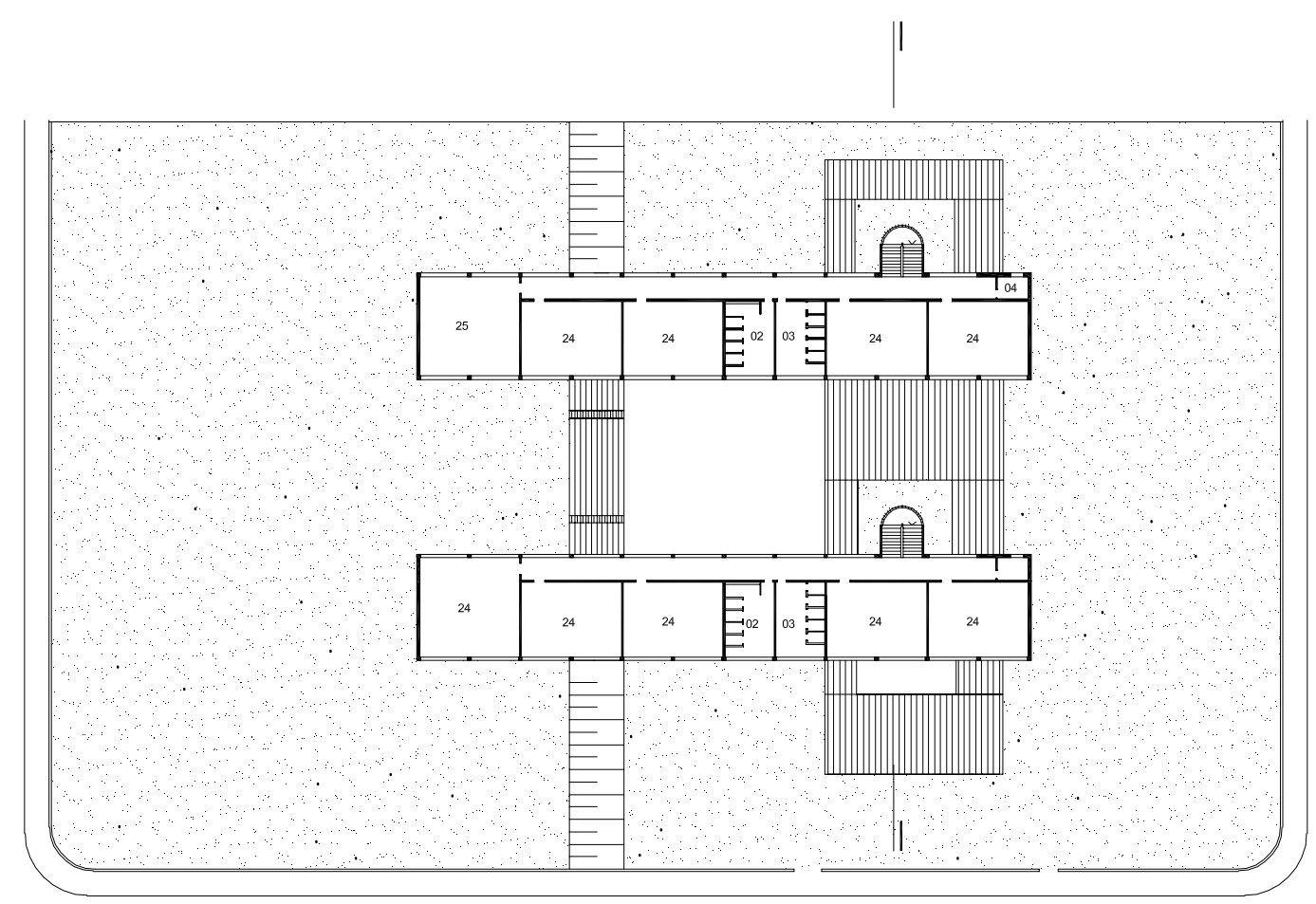

IMPLANTAÇÃO / PRIMEIRO PAVIMENTO 1:750

\begin{tabular}{llll}
\hline & 5 & 10 & 25
\end{tabular}

LEGENDA 01. HALL DE ENTRADA
02. SANITARIO MASCULINO 03. SANITARIO FEMININO 04. SANITARI
55. SALA DE TRABALHO MANU OG. VESTIARRIO MASCULINO O. VESTIARRIO FEMININO 08. VESTIARIO FEMININO
Og. RECREIO COBERTO 10. PAEEO DE ESPETACULOS
11. SECRETARAA 12. DIRETOR
13. SALA DOS PROFESSORES

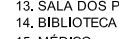
14. BIELOTECA
15. MEDLCO
16.LADE ESPERA 17. DENTISTA
18. ASSISTENTE SOCIAL
19. NUTTICIONISTA 20. IISTRBIULICĀA
21. COZZNHA 22. CABINE DE PROJECGÁ
23. 2 ELADORAA 23. ZEEADORA
24. SALA DE AULA
CORTE

\begin{tabular}{l}
\hline \\
0 \\
\hline
\end{tabular} 


\section{EE Gabriela Mistral (1952)}

Localiza-se no bairro do Tucuruvi em terreno de modestas dimensões, mas, apesar disso, o arquiteto propôs um edifício térreo com recreio coberto em abóbada. Essa escola repete, em sua implantação, a articulação dos três blocos funcionais independentes (administrativo, ensino e recreação), típicos das escolas do convênio, conectados através de passagens cobertas; no conjunto, destaca-se o bloco de ensino que remete à solução em arcos da escola do arquiteto Reidy no conjunto habitacional Pedregulho, no qual a cobertura do ginásio é também resolvida através de um conjunto de abóbadas.
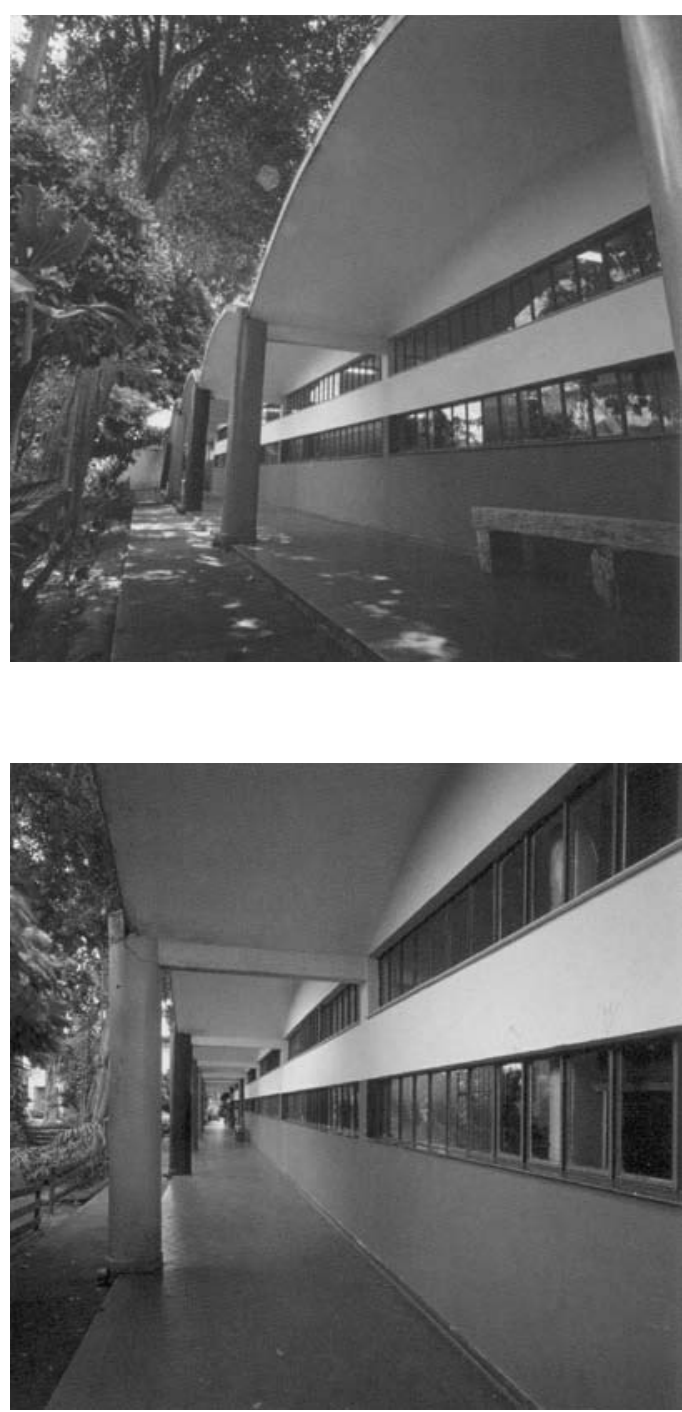

SEQÜÊNCIA de ARCOS CARACTERIZA O BLOCO DE ENSINO 

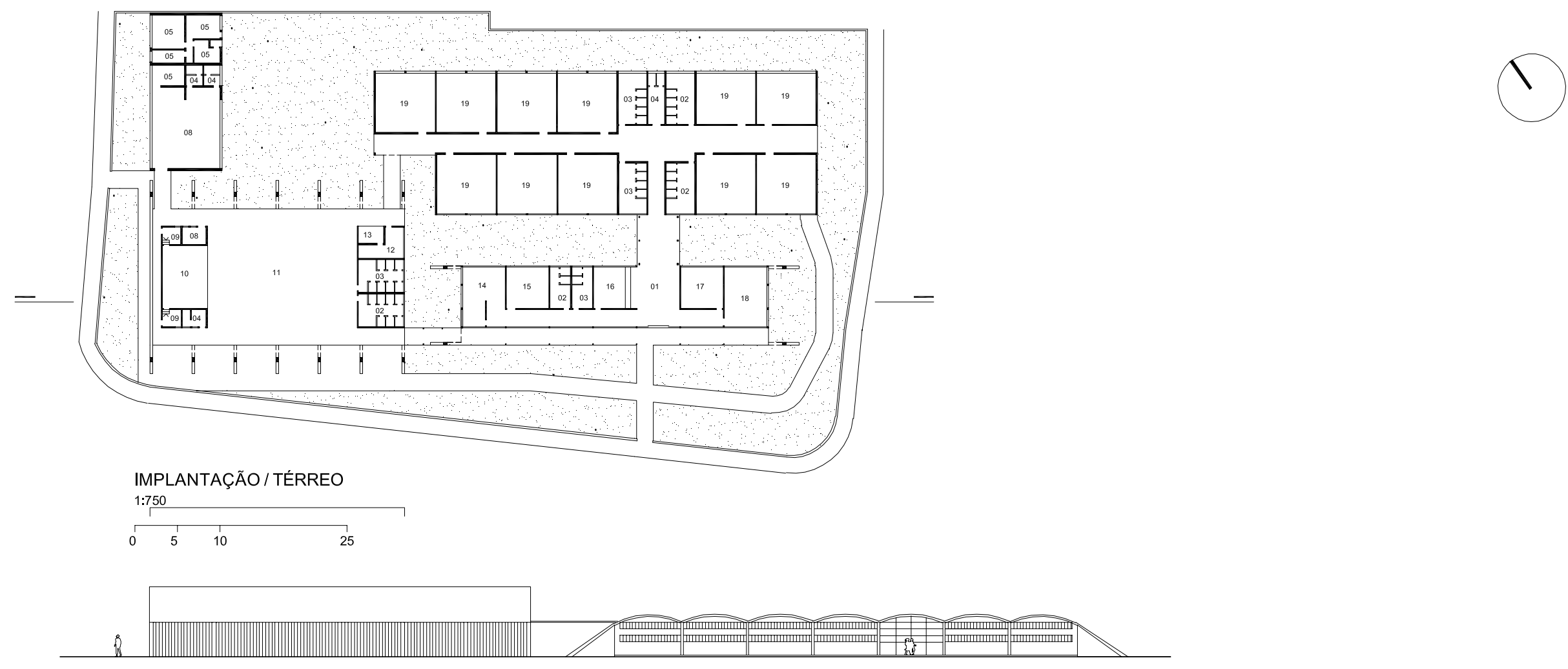

ELEVAÇÃO SUDOESTE
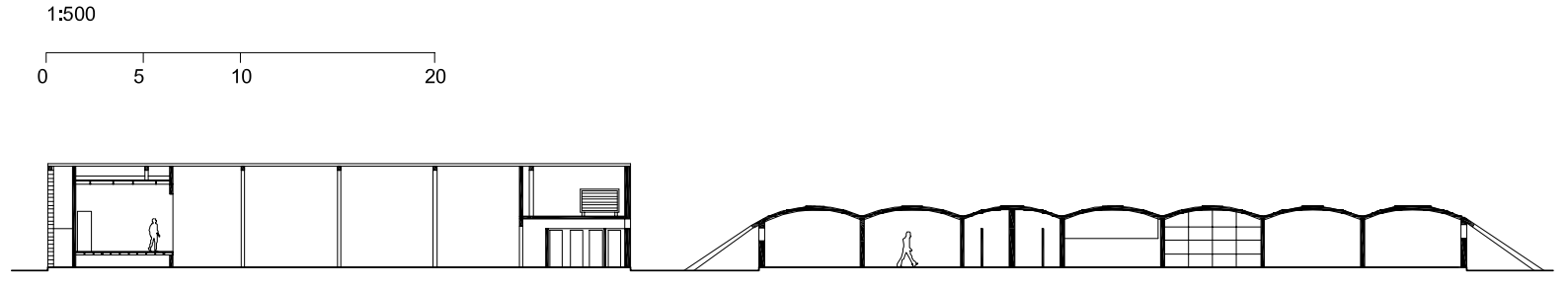

CORTE 


\section{ARQUITETO ROBERTO GOULART TIBAU}

Tibau participou efetivamente do $2^{\circ}$ e $3^{\circ}$ Convênios Escolares, entre os anos de 1951 e 1955, razão pela qual tem a maior produção de edifícios, ao lado do arquiteto Hélio Duarte. Foi encarregado de dar continuidade ao método de produção, seus fundamentos teóricos e projetos arquitetônicos do $2^{\circ}$ Convênio para a equipe de arquitetos contratada para o $3^{\circ}$ Convênio, a partir de 1953.

Recém-formado pela Escola Nacional de Belas Artes, do Rio de Janeiro, por volta de 1945, foi contratado pelo engenheiro José Amadei, presidente da Comissão Executiva do $2^{\circ}$ Convênio Escolar, para fazer parte da equipe, com a finalidade de acompanhar a execução das obras. Solicitado, porém, a fazer uma proposta de projeto arquitetônico para a escola rural do Butantã (Escola Alberto Torres), e em função do resultado alcançado, não parou mais de fazer projetos para o convênio, o que alavancou sua vida profissional (avaliou ter construído mais de 500 escolas em sua carreira de arquiteto).

Tibau produziu oito edifícios escolares durante a vigência do $2^{\circ}$ Convênio Escolar e, no conjunto de sua obra, apresentou soluções volumétricas específicas para os variados programas propostos (escola rural, escola de aplicação ao ar livre, escola de grande porte com anfiteatro e piscina). Foi o arquiteto que produziu a maior variedade de escolas de acordo com o experimentalismo permitido nas pesquisas desenvolvidas pela equipe de arquitetura do convênio. 
Dos oito projetos realizados, seis configuraram-se a partir de blocos funcionais independentes, conectados através de marquises ou prolongamentos de coberturas tipo asa de borboleta. Os outros dois projetos organizaram-se em um único volume de 3 pavimentos, em função das características topográficas do terreno.

Quanto ao recreio coberto, somente um edifício escolar utilizou-se de cobertura abobadada; dos sete restantes, dois edifícios térreos cobriram seus recreios com uma água de cobertura asa de borboleta e os outros cinco abrigaram seus recreios sob pilotis.

Seguem as escolas: 


\section{EE Doutor Edmundo de Carvalho (1950)}

Essa escola está localizada no bairro da Lapa, e foi a única do convênio a aplicar o conceito de "aulas ao ar livre"; em que cada uma das salas de aula, térreas, se integram a pátios de uso exclusivo através de grandes caixilhos. Esse projeto destacase também, por sua econômica implantação, ao aproveitar o desnível existente e configurar com isso o recreio coberto sob pilotis.

A escola caracterizou-se volumetricamente por três blocos funcionais: o primeiro, administrativo, é térreo e sua volumetria é marcada pela cobertura em asa de borboleta; o segundo, em 2 pavimentos, abriga em seu térreo em pilotis o recreio coberto, com salas especiais para dança e pequeno ambulatório médico e, em seu pavimento superior, acessado através de um conjunto de rampas, as salas de aula. $\bigcirc$ terceiro bloco caracterizou-se por um conjunto de salas de aula, separadas por pátios externos e conectadas umas às outras através de uma marquise em concreto.

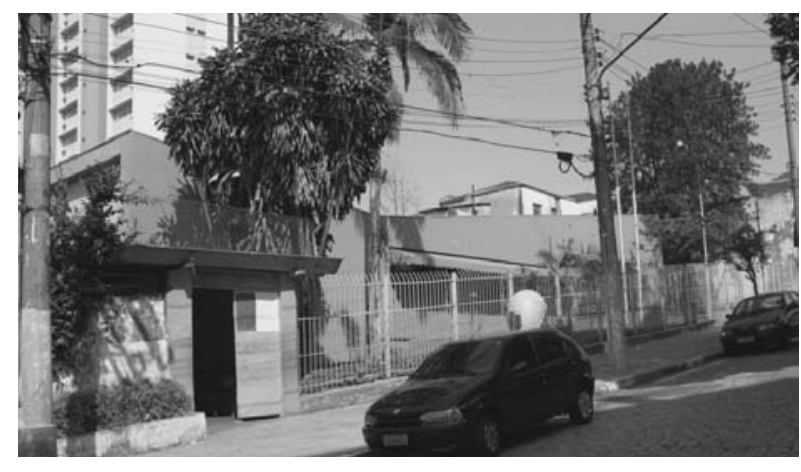

A COBERTURA EM ASA DE BORBOLETA CARACTERIZA O BLOCO ADMINISTRATIVO 


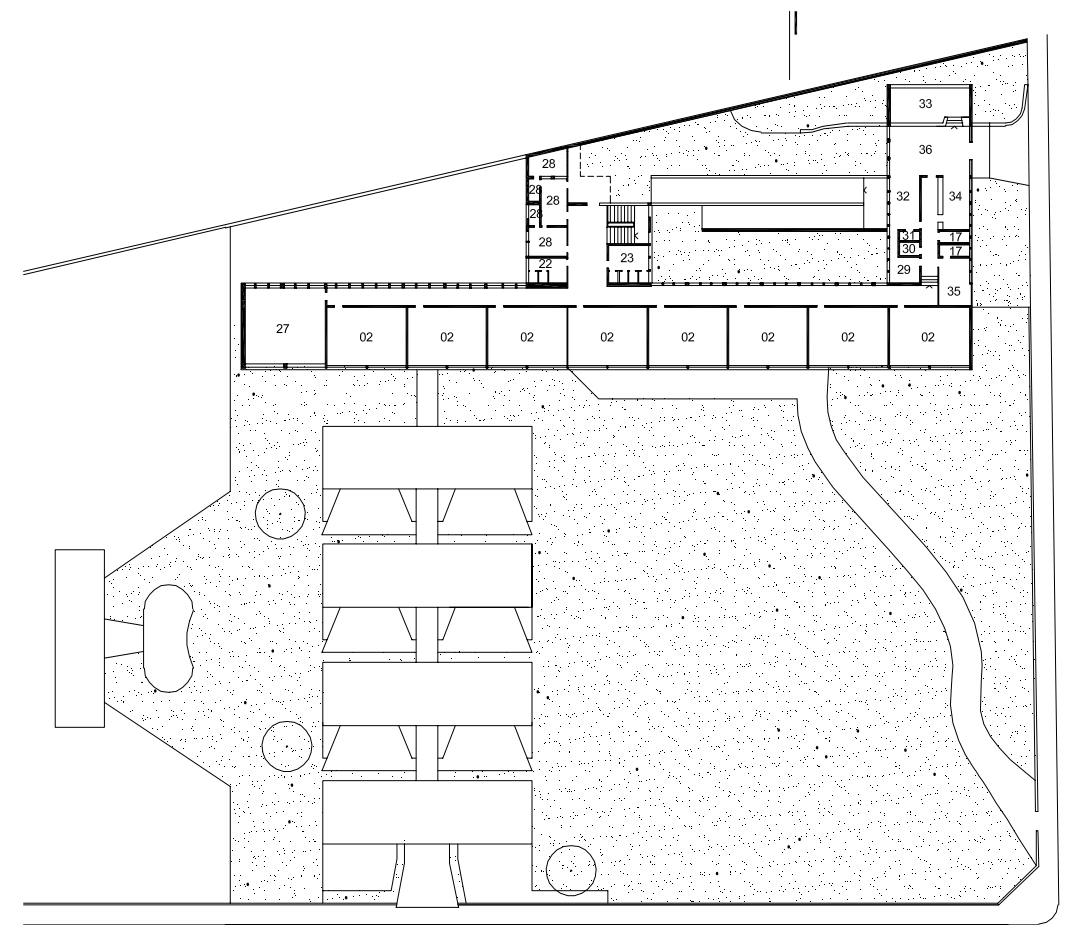

IMPLANTAÇÃO / PRIMEIRO PAVIMENTO 1:750

\begin{tabular}{ll|l}
\hline & 5 & 10
\end{tabular}

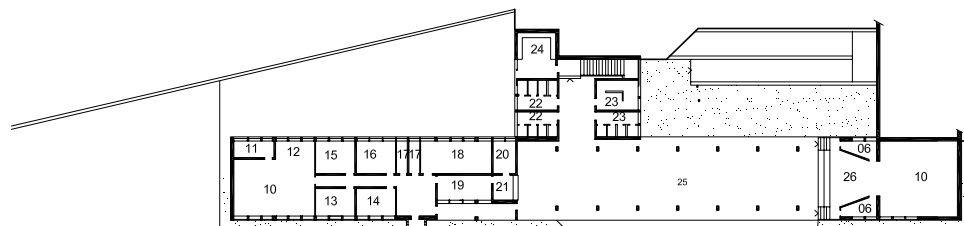

$\ldots \sqrt{13} \sqrt{14}]$

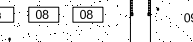

\begin{tabular}{lllll}
\hline 06 & 1 & 07 & I & 06 \\
\hline
\end{tabular}

03

$02[$ [b 0 [ 02

(2)

का

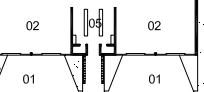

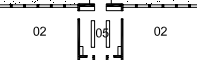

\section{PAVIMENTO TÉRREO}

1:750

\begin{tabular}{llll}
\hline & 5 & 10 & 25
\end{tabular}
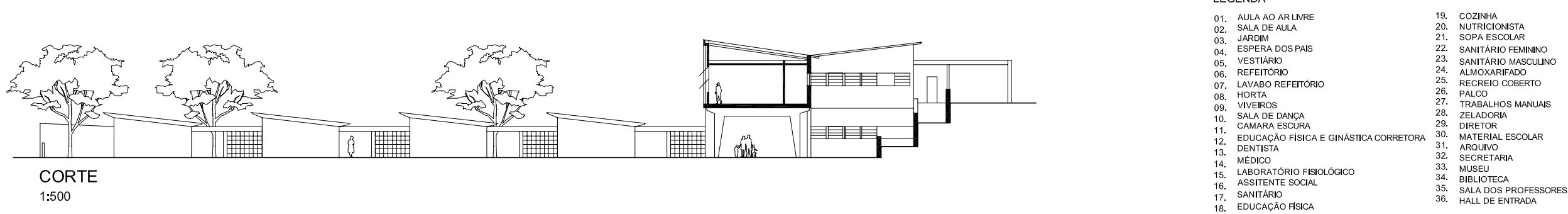

1:500

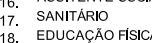




\section{EE Alberto Torres (1951)}

Tibau foi encarregado de projetar essa, que foi a única escola rural do convênio. Construída em uma generosa área totalmente plana, no bairro do Butantã, é vizinha do Instituto de mesmo nome.

Nesse projeto, Tibau utilizou-se da tipologia básica idealizada por Hélio Duarte: bloco de ensino em 2 pavimentos, bloco de recreação abobadado e bloco administrativo, esse último, térreo, apresentando pequenas janelas e cobertura em asa de borboleta. Os blocos foram conectados por marquises em concreto. Trata-se de programa arquitetônico muito específico, conforme pode ser comprovado pelas plantas apresentadas a seguir. 


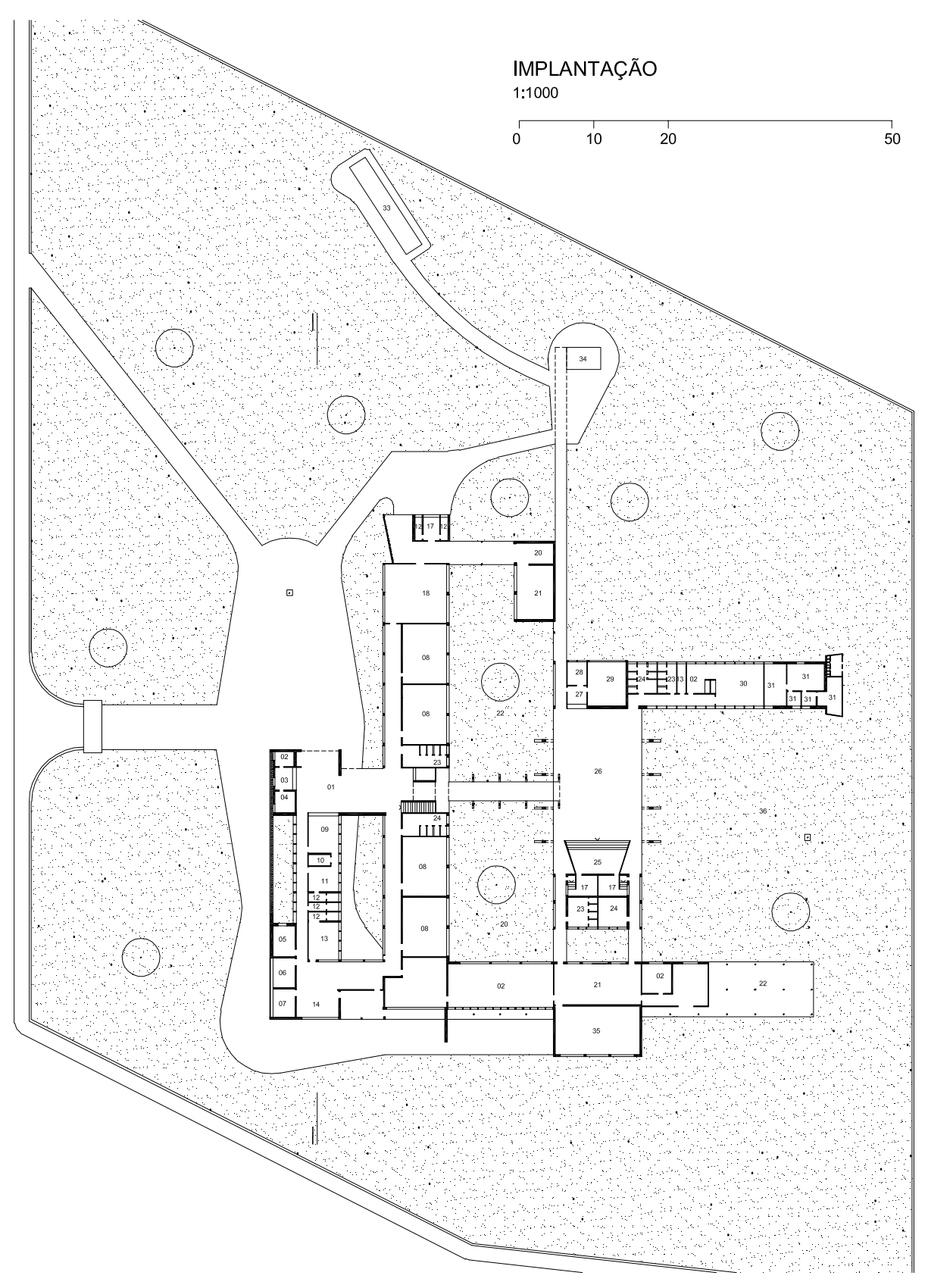

PRIMEIRO PAVIMENTO

1:1000
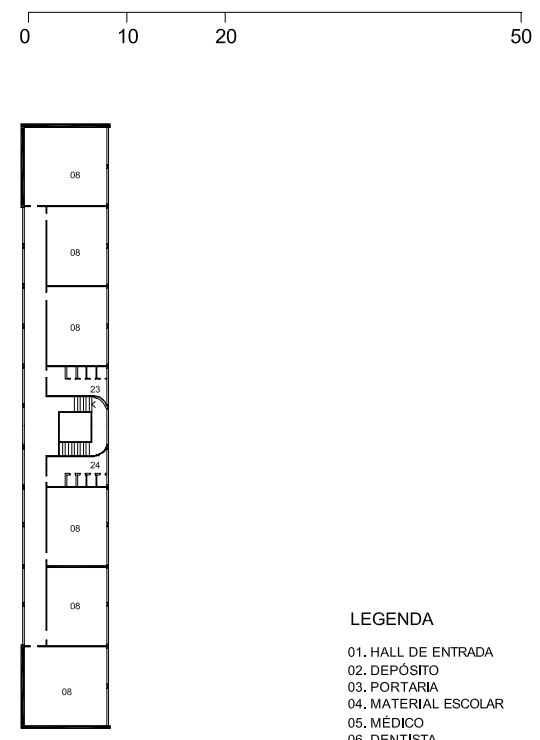

LEGENDA

$\begin{array}{ll}\text { 01. HALL DE ENTRADA } & \text { 19. REEEIT́́RIO } \\ \text { 02. DEPOSITO } & \text { 20. RECREIO }\end{array}$

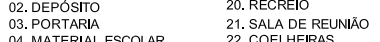

04. MATERIAL ESCOLAR

05. MÉDICO
06. DENTISTA

07. DENSIISTA
07. ASISTENCAASO

08. SALA DE AULA
09. SERETTRAAA

11. ARRETORIA

12. SANITARIO
13. SAA DOS PROFESSO
14. SALA DE ESPERA

15. PATEO

16. JARDIM DE IN

21. SALA DE REUNIAOO
22. COELELRAS
23. SANITARIO MASCU

23. SANITARIO MASCULINO
24. SANITARIO FEMININO

25. PALCO

27. DISTRBBUICĀAO

28 NUTRICIONISTA
29 COZINHA

30. CARPNTAARAA
31 ZELADOPRA

32. QUADRA POLESPORTIVA

33. APIARIO
3. ISRARRA
35. TECELAGEM 

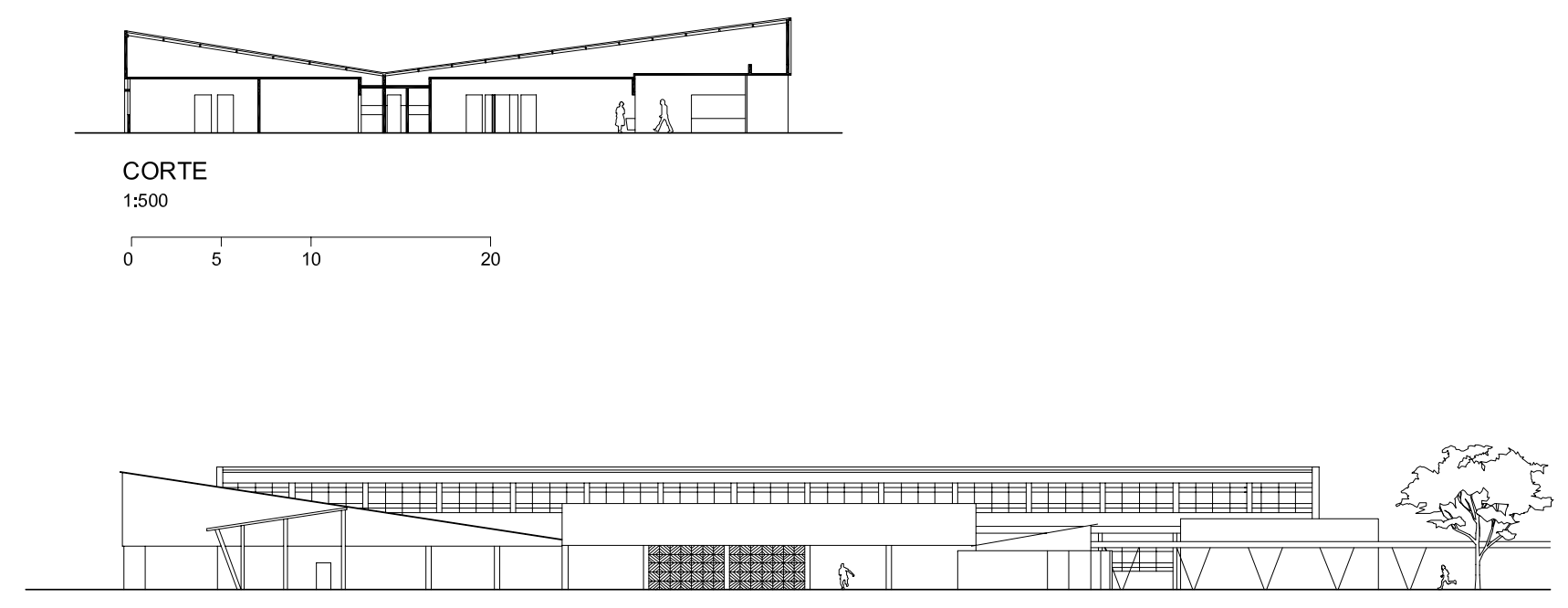

ELEVAÇÃO NORDESTE

1:500

\begin{tabular}{llll}
\hline & 1 & 1 & 20
\end{tabular}

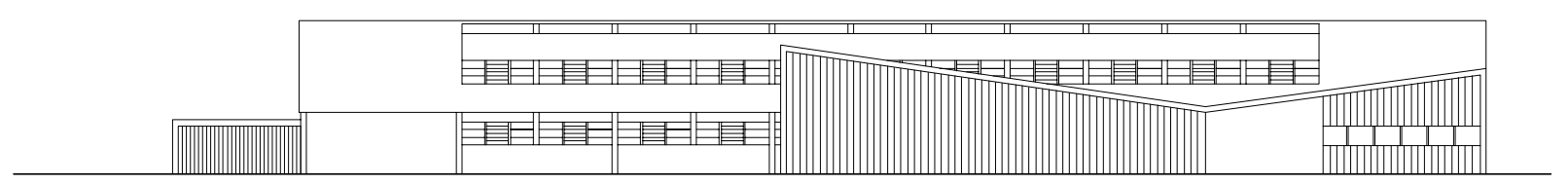

ELEVAÇÃO SUDOESTE

1:500

\begin{tabular}{llll}
\hline & 1 & 10
\end{tabular} 


\section{EE Comendador Mário Reys (1951) e EE Professor Ascânio de Azevedo Castilho (1951)}

Escolas localizadas no bairro de Itaquera, foram construídas a partir do mesmo projeto e adequadas, em sua implantação, a fim de garantir a face nordeste para insolação das salas de aula.

Singelas, são térreas e caracterizam-se pela articulação de dois blocos, o de ensino e o administrativo, onde o recreio coberto, localizado no meio do bloco de ensino, é abrigado por uma das águas da cobertura em asa de borboleta que cobre o conjunto. Um pátio interno, descoberto, organiza toda a circulação desse edifício escolar. 
:

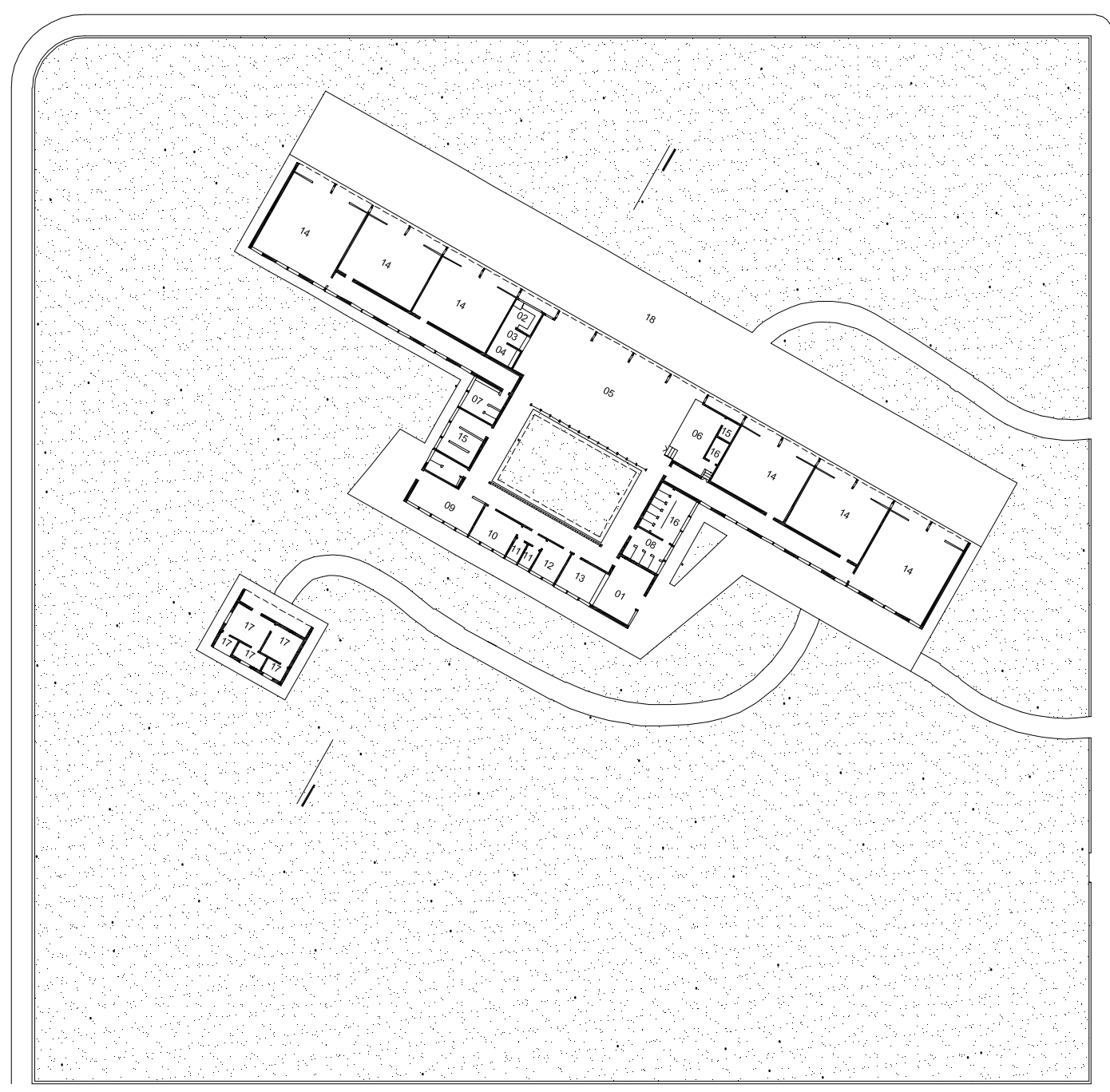

ELEVAÇÃO NORTE

\begin{tabular}{l|l|l}
\hline & 5 & 10
\end{tabular}
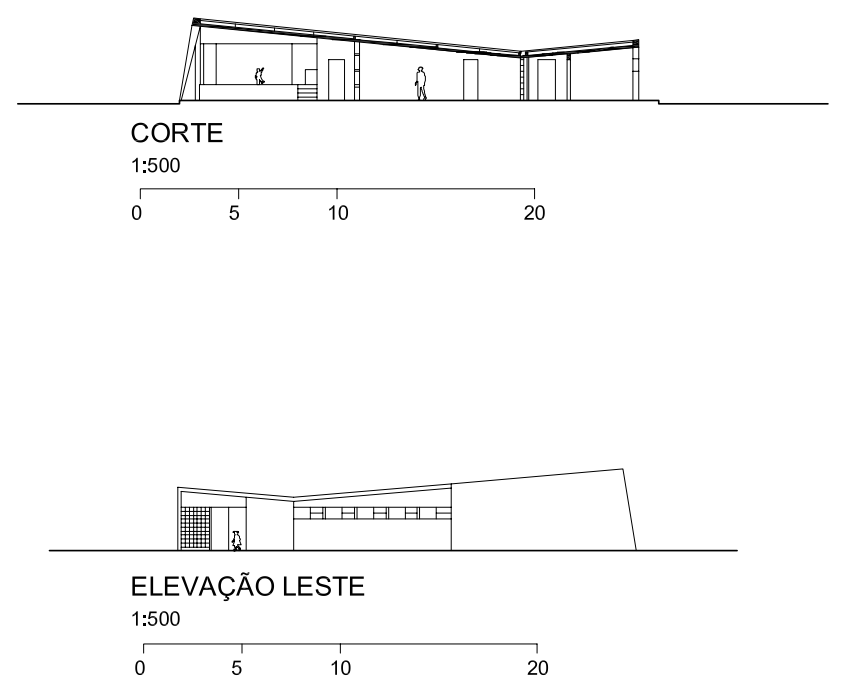

IMPLANTAÇÃO / TÉRREO $1: 750$

\begin{tabular}{llll}
\hline 0 & 5 & 10 & 25
\end{tabular}
LEGENDA 01. HALL DE ENTRADA

0.4. NUTRCIOIOIOA
05. GALPAO 06. PALCO

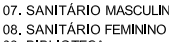
O8. SANTARIO FEMINIO
O9. BBLLOTECA

10. SALA DOS PROFESSORES

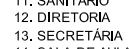
15. VESTARRO MASCULINO 16.VESTARIO FEMNMO
17. ZELADORA 18. SABRO 


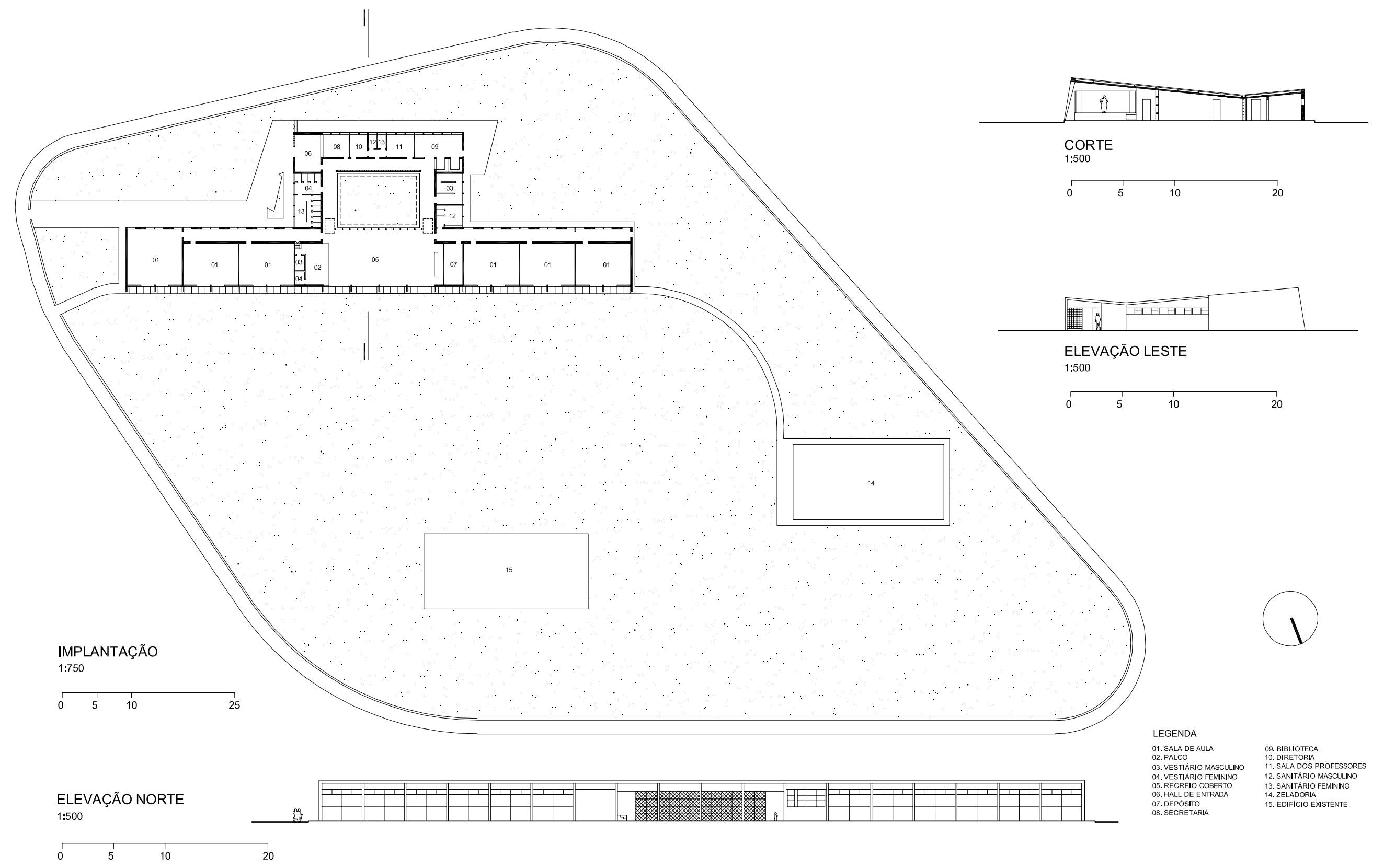

224 EE Professor ASCANIIO dE AZEVEDO CASTILHO 


\section{EE Artur Sabóia (1952)}

Localizada no Bairro da Saúde, essa pequena escola, com apenas cinco salas de aula, chama a atenção pela referência que faz aos pórticos da fábrica de bolachas Duchen, que definem a volumetria do recreio coberto. Pórticos estruturais marcam, também, o ritmo do bloco que abriga o setor de ensino e o setor administrativo em dois pavimentos, anunciando, nesta experimentação, um importante traço da escola paulista de arquitetura, na apropriação da estrutura como elemento conformador da composição arquitetônica. 


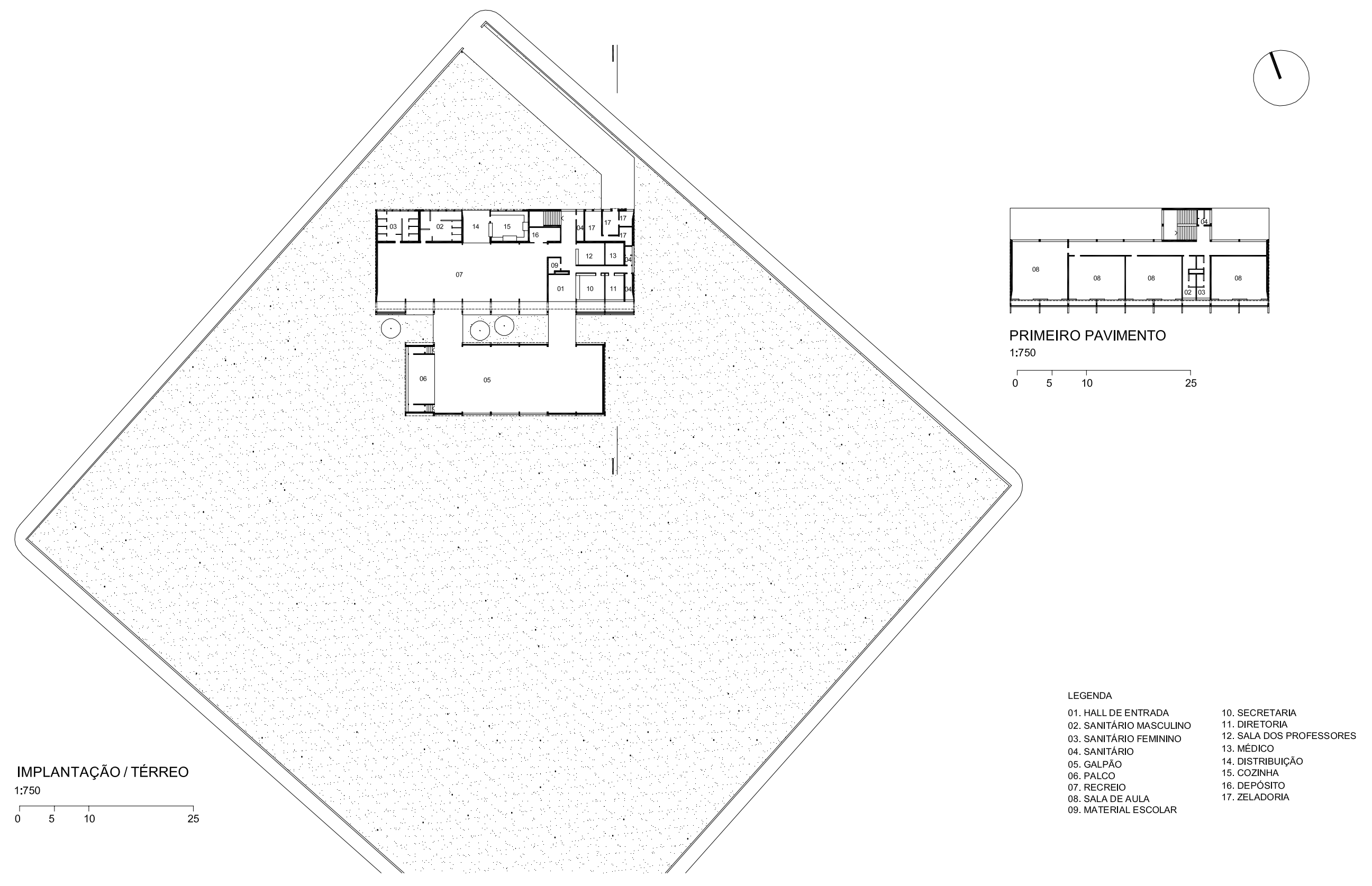



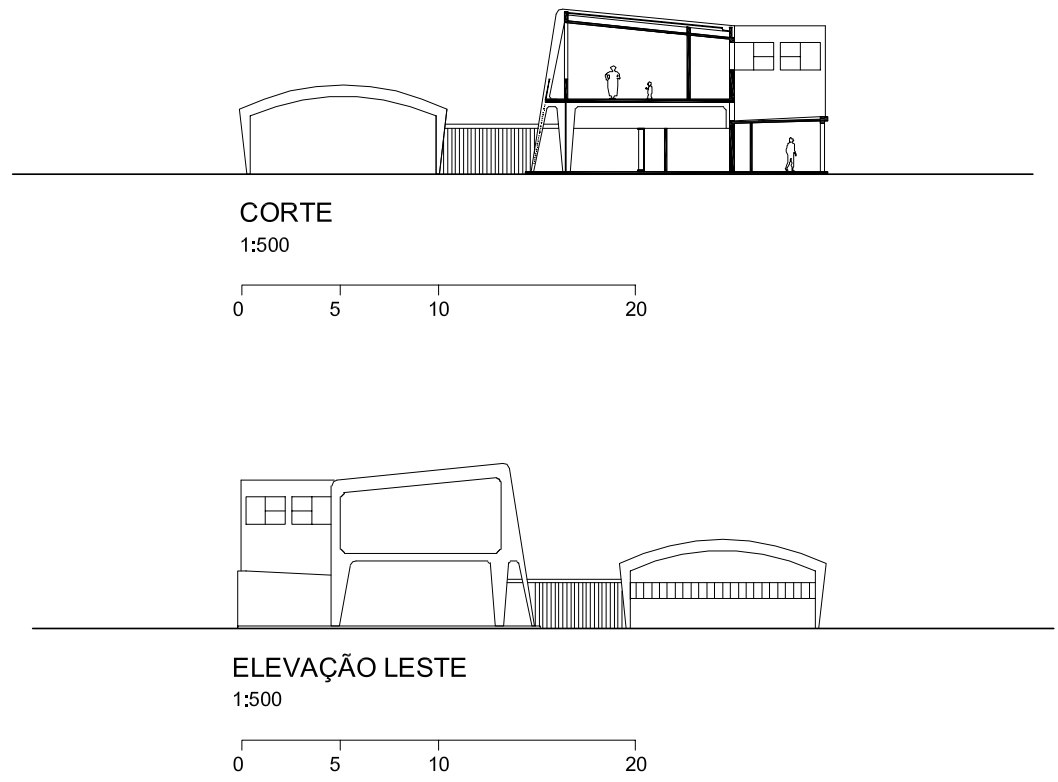
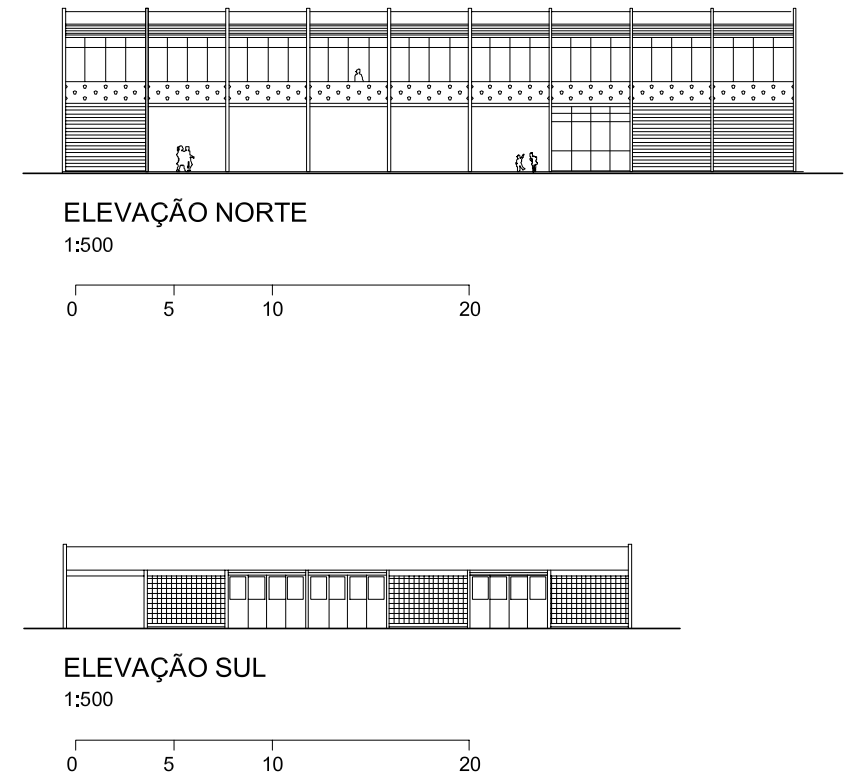


\section{EE Clóvis Bevilacqua (1950) e EE Dona Suzana de Campos (1953)}

A primeira escola localiza-se no bairro de Perus e a segunda, no bairro de Perdizes. As duas escolas foram construídas a partir do mesmo projeto arquitetônico, devido às questões topográficas, similares nas duas situações.

A forma final da escola é caracterizada por um bloco único com três pavimentos: o bloco administrativo localiza-se no primeiro andar, no nível da rua, o bloco de recreação localiza-se no térreo, sob o pilotis, e o bloco de ensino divide-se entre o primeiro andar, ao lado da administração, e o $2^{\circ}$ andar. 

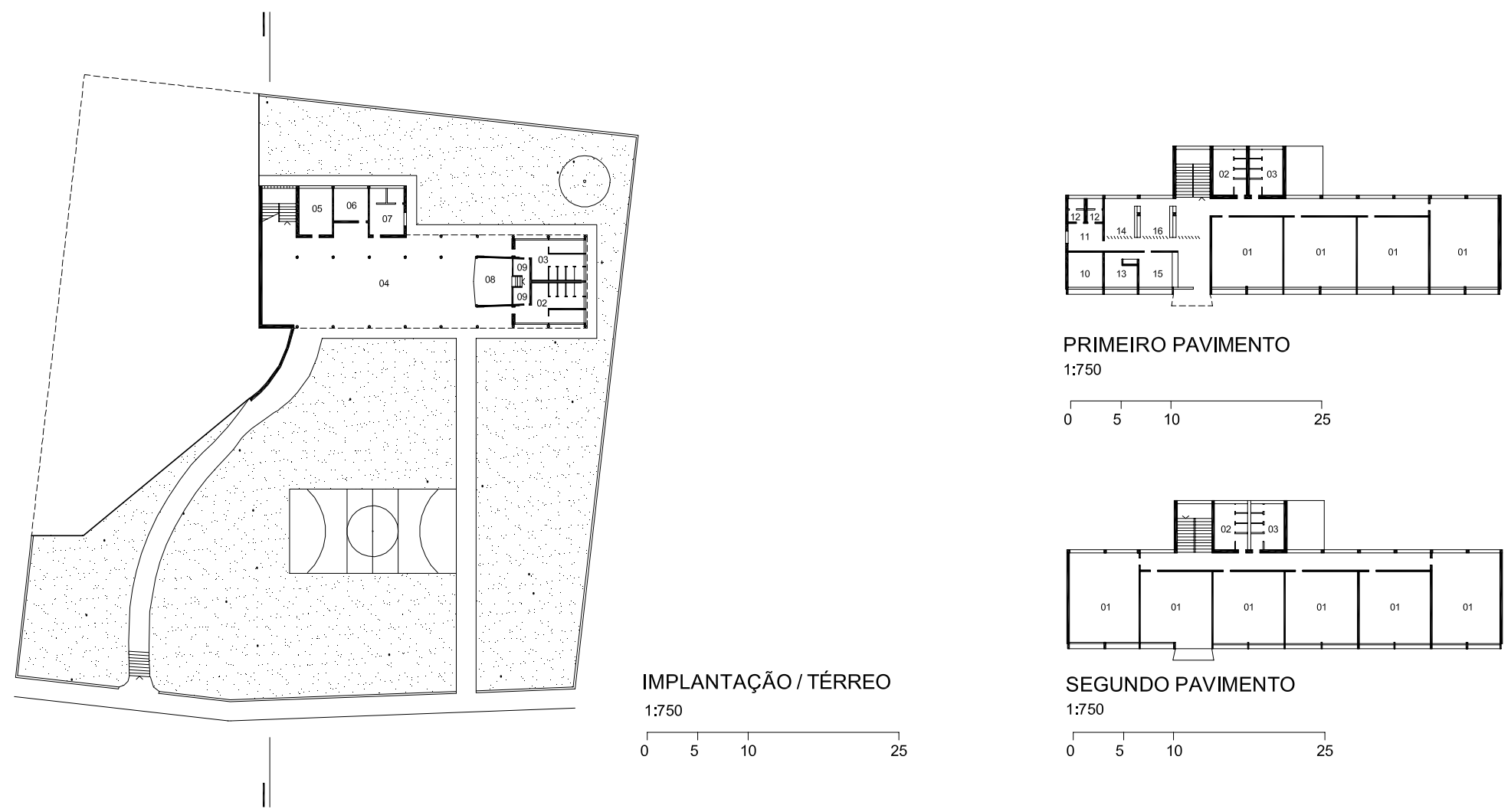

PRIMEIRO PAVIMENTO

1:750

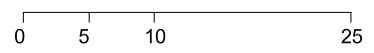

IMPLANTAÇÃO / TÉRREO 1:750
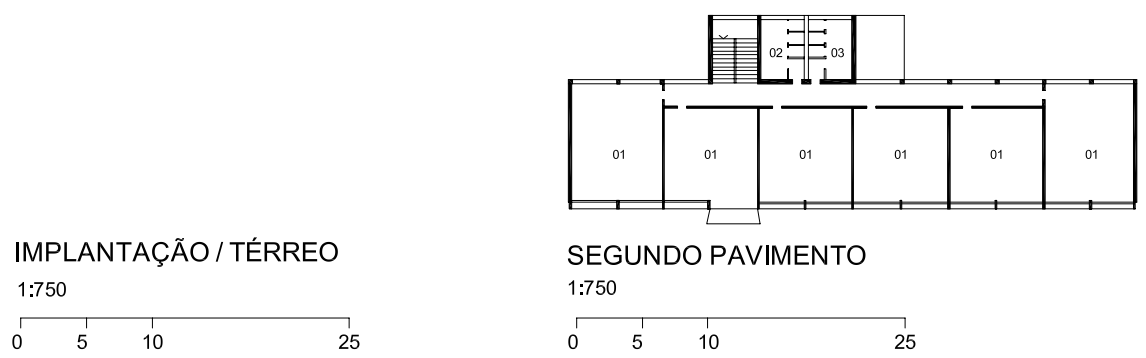

SEGUNDO PAVIMENTO

1:750

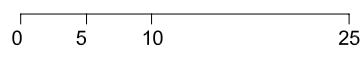

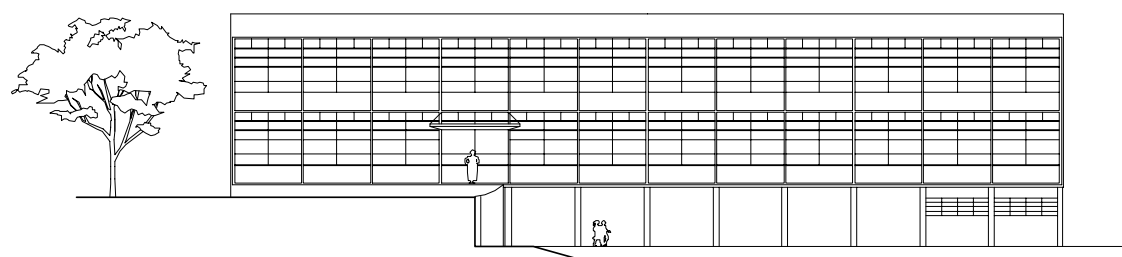

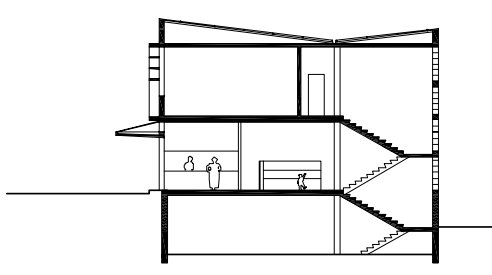

CORTE

1:500

1:500

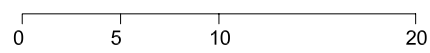




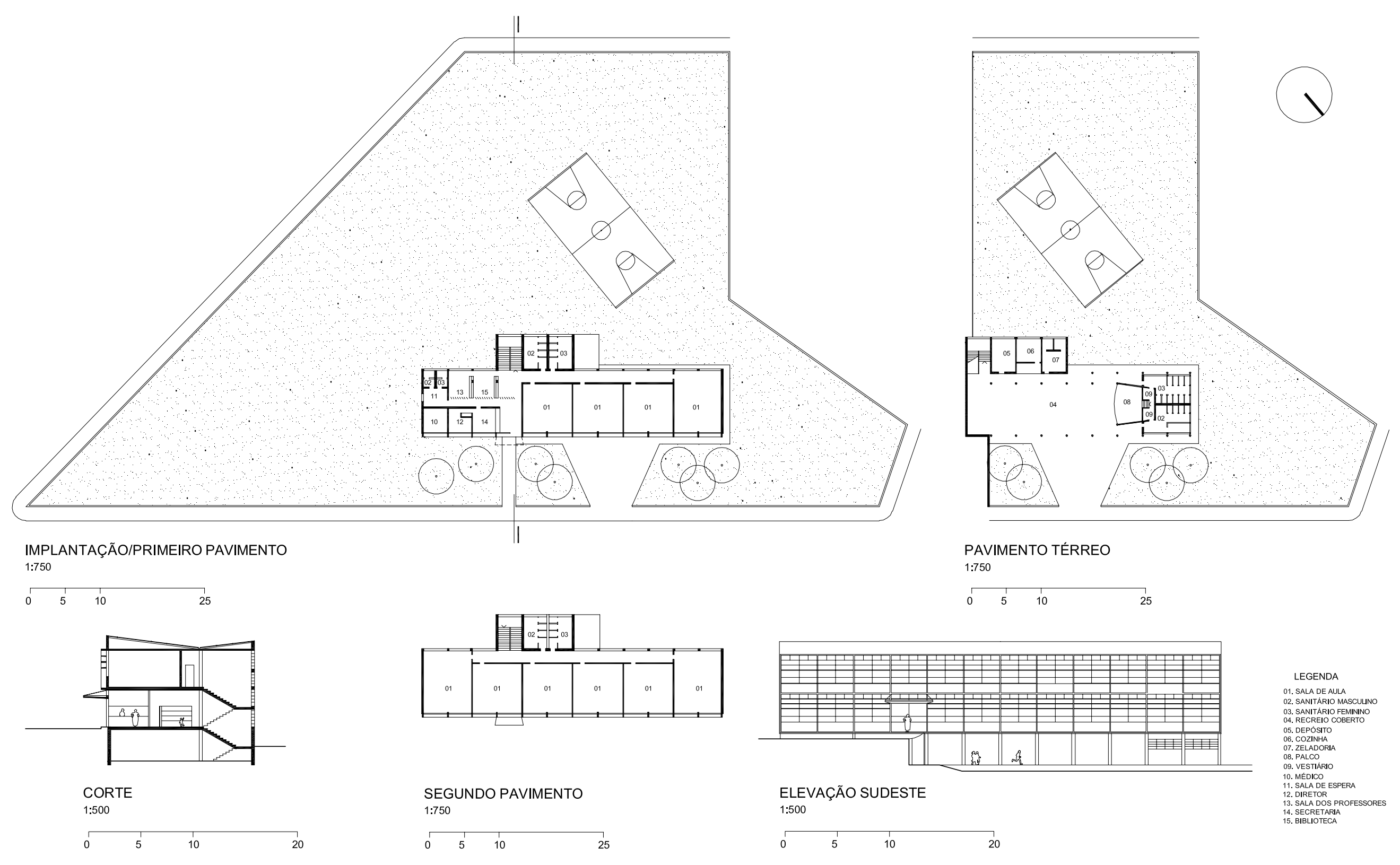




\section{EE Professor Alberto Conte (1953)}

Localizada no bairro de Santo Amaro, essa escola, contempla, além dos ambientes do programa básico, salas ambientes para disciplinas específicas, piscina, auditório e quadra poliesportiva.

Uma das escolas de maior área construída pelo convênio, sua volumetria caracteriza-se pela conexão ortogonal de um bloco horizontal térreo (administrativo), que abriga, em uma de suas extremidades, o anfiteatro, e um bloco vertical com 3 pavimentos, que abriga no térreo o recreio coberto em seu pilotis e, no restante, as salas de aula, salas ambientes para disciplinas específicas e laboratórios.

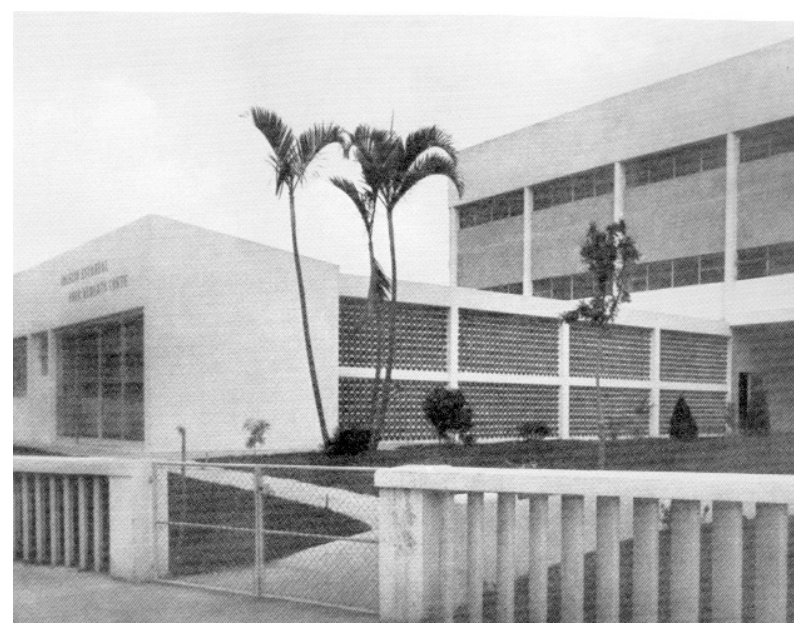

BLOCO DE ENSINO APOIADO SOBRE BLOCO ADMINISTRATIVO 

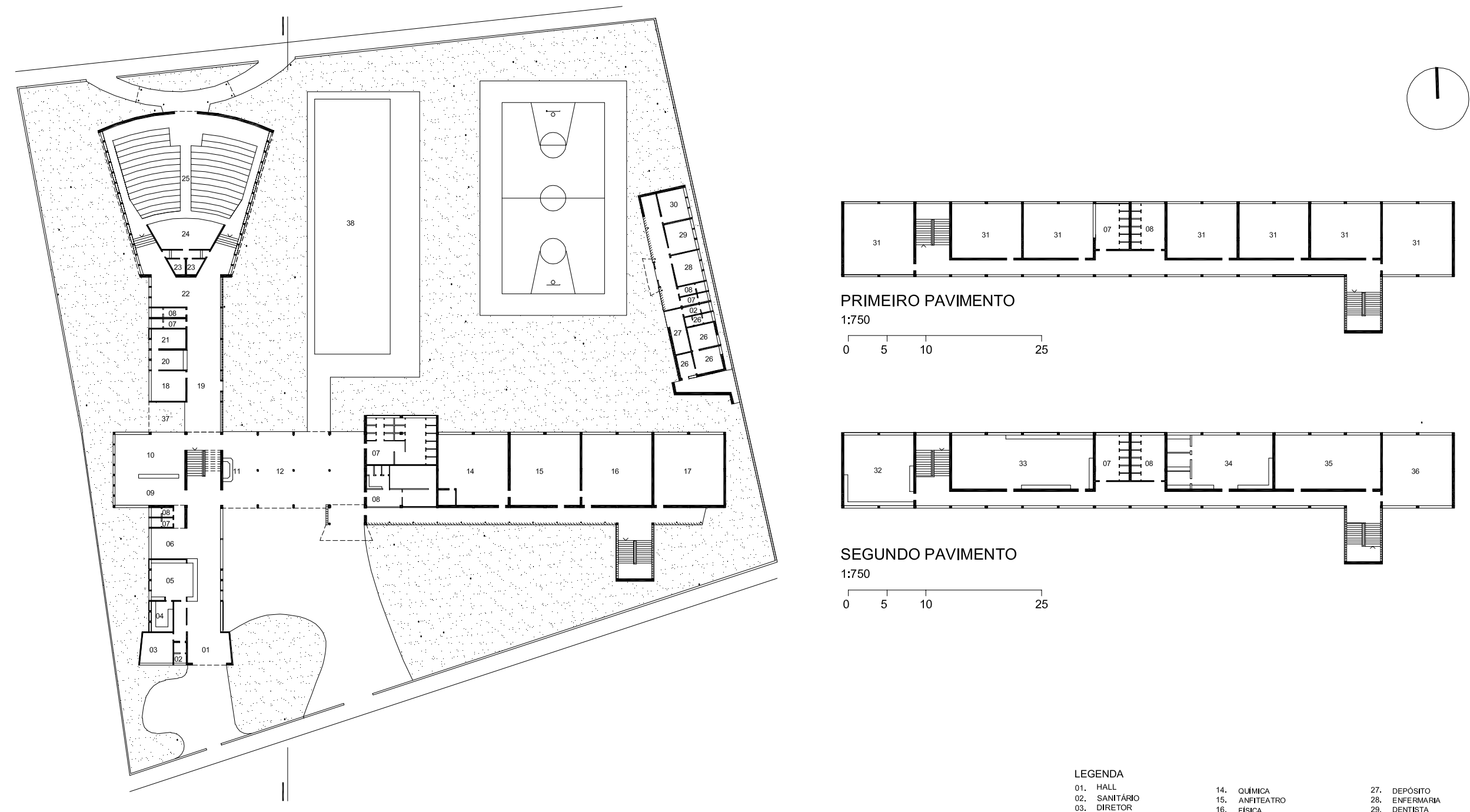

IMPLANTAÇÃO / TÉRREO

1:750
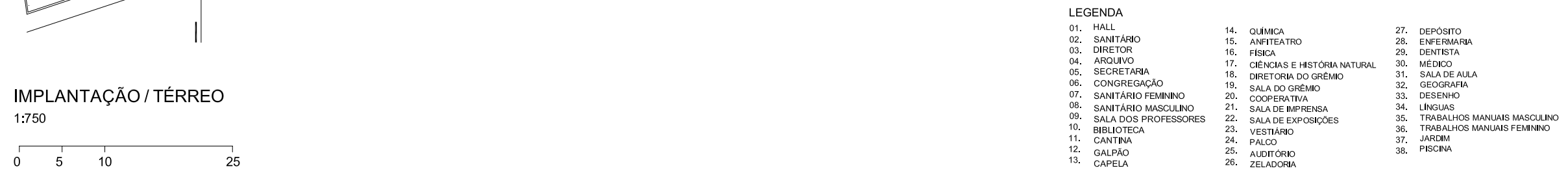

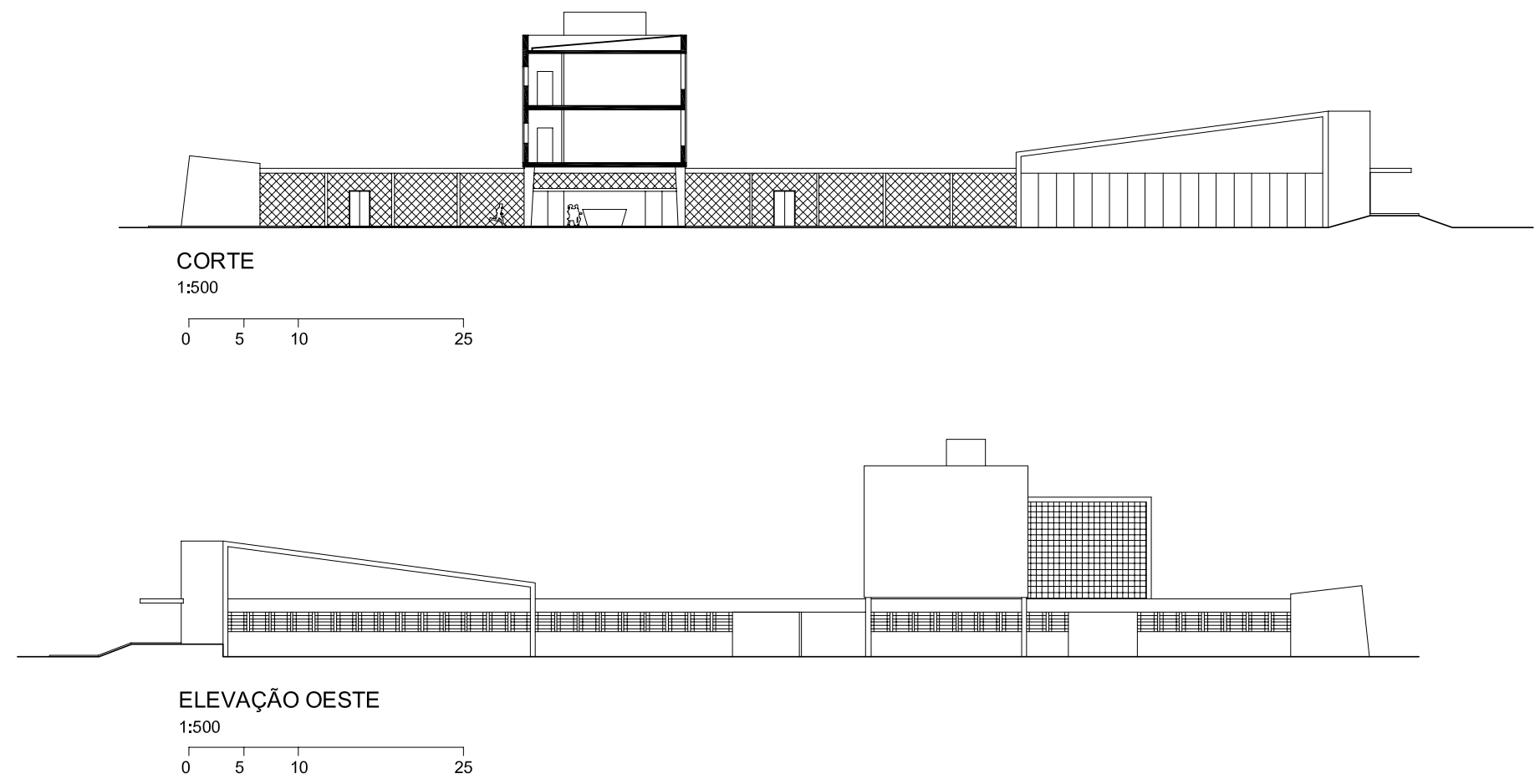


\section{ENGENHEIRO ERNEST ROBERT DE CARVALHO MANGE}

Sua contribuição foi marcante na área técnica, e poderíamos caracterizá-lo como o mais teórico de todos os projetistas do convênio, até porque teve sua formação técnica na área de engenharia. Escreveu vários artigos, registrando a necessidade de a equipe ter fundamentação teórica e técnica, através do conhecimento de fórmulas físicas e matemáticas para apoiar suas definições projetuais. Defendia o conhecimento profundo das questões pedagógicas para a formatação adequada do programa arquitetônico a ser atendido.

Projetou seis escolas entre os anos de 1950 e 1951 e, em todas, propôs a implantação a partir de blocos funcionais independentes, articulados e entremeados por pátios internos. Cinco delas apresentam recreio sob pilotis e uma escola, recreio coberto por arco em abóbada.

$\mathrm{Na}$ análise de seus projetos, encontramos, em cinco de suas escolas, a mesma solução volumétrica, racionalizada a partir de dois blocos separados por um pátio central (com cobertura em asa de borboleta), no intuito de contemplar iluminação bilateral para todas as salas de aula.

Esse rigor gerou um curioso conjunto de escolas em que as variações, consideradas as questões relativas à topografia do terreno, mantêm a mesma relação volumétrica entre os dois blocos. Há que se considerar a extrema racionalidade que a repetição dessa solução trouxe para o desenvolvimento dos projetos e a construção desses edifícios escolares. 


\section{EE Domingos Faustino Sarmiento (1950)}

Localizada no bairro do Brás, essa escola está implantada em um terreno plano e caracteriza-se, volumetricamente, a partir da implantação de dois blocos.

O bloco de salas de aula, em 2 pavimentos, tem garantida iluminação bilateral, em função dos pátios internos que separam esse bloco do outro, também em 2 pavimentos, no qual o setor administrativo está sobre o recreio coberto, estruturado a partir de pilotis.

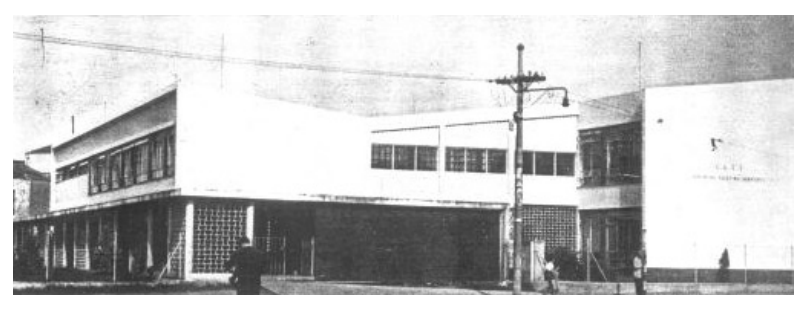

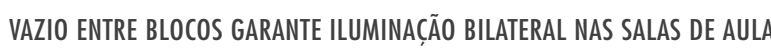



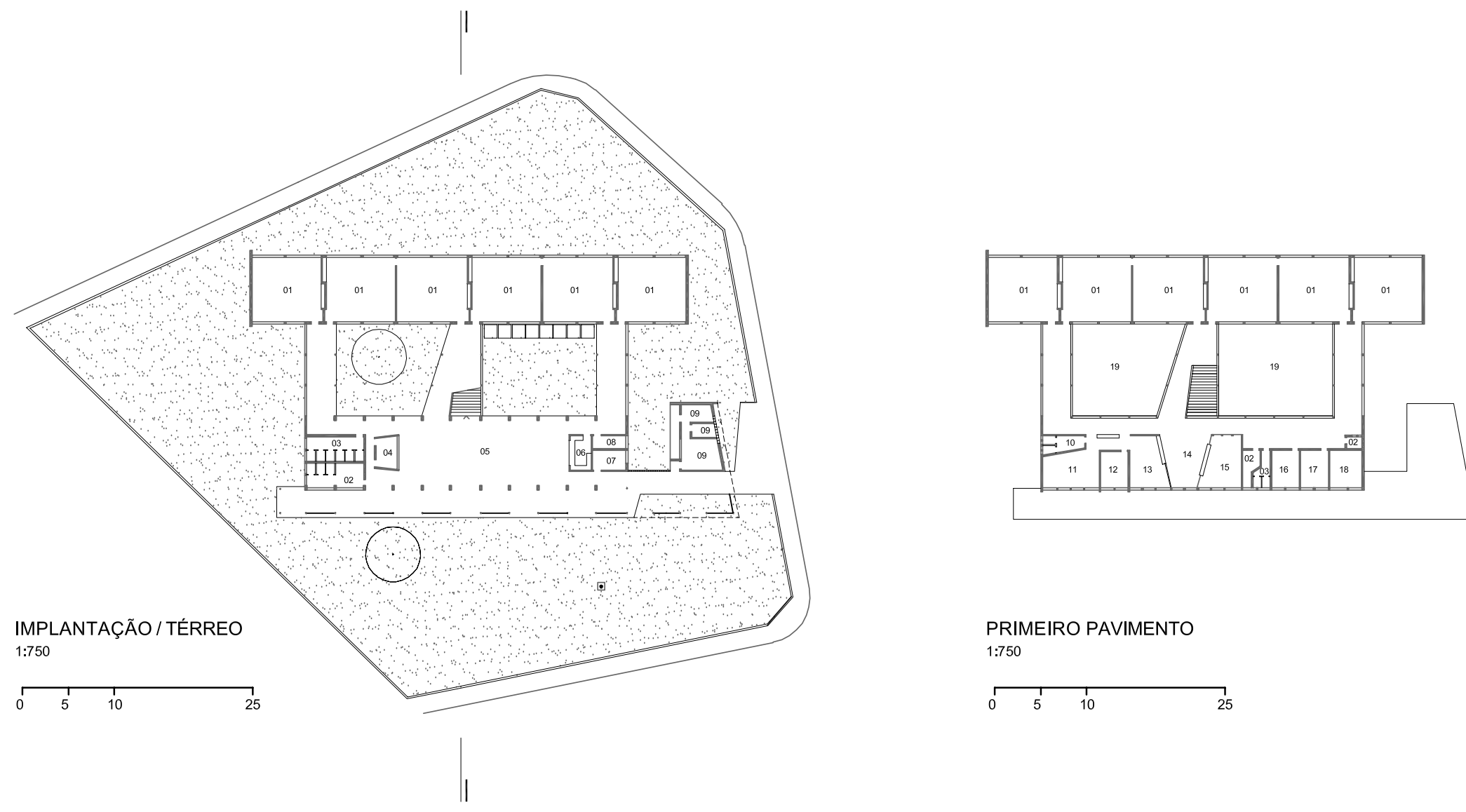

PRIMEIRO PAVIMENTO

1:750

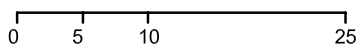

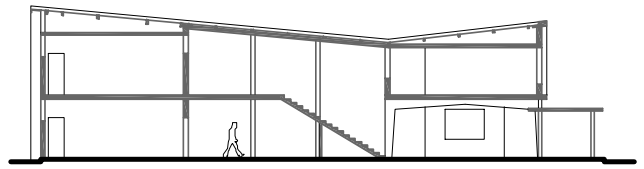

CORTE

1:500

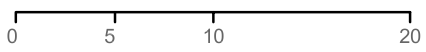

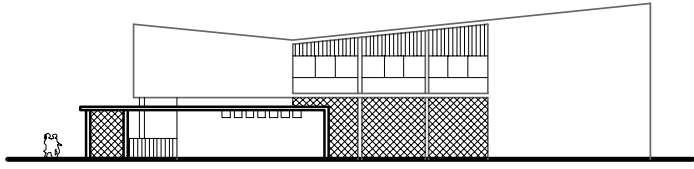

ELEVAÇÃO LESTE

1:500

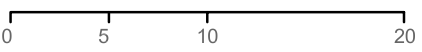

EEGENDA

SALA DE AULA 11. SALA DOS PROFESSORES 04. PALCO COZINHA

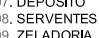
D. ZEAADTRA 


\section{EE General Antônio de Sampaio (1950), EE República do Chile (1950) e EE Professora Isabel Vieira de Serpa e Paiva (1951)}

A primeira escola localiza-se em Osasco, a segunda, no bairro de Vila Nova Cachoeirinha e a terceira no bairro do Jaraguá. Essas três escolas repetem o mesmo projeto, mas com uma pequena variação como solução para a caixa de escada, adaptada ao terreno. Implantam-se em terreno em aclive, no qual dois blocos se articulam através das circulações cobertas.

A cobertura do conjunto em asa de borboleta cobre os dois blocos e também suas passarelas de ligação; no primeiro bloco, em 2pavimentos, encontramos o setor administrativo sobre o recreio coberto e, no segundo, térreo, encontramos o conjunto de 6 salas de aula. $\bigcirc$ pátio, entre os blocos, garante iluminação bilateral para as salas de aula. 


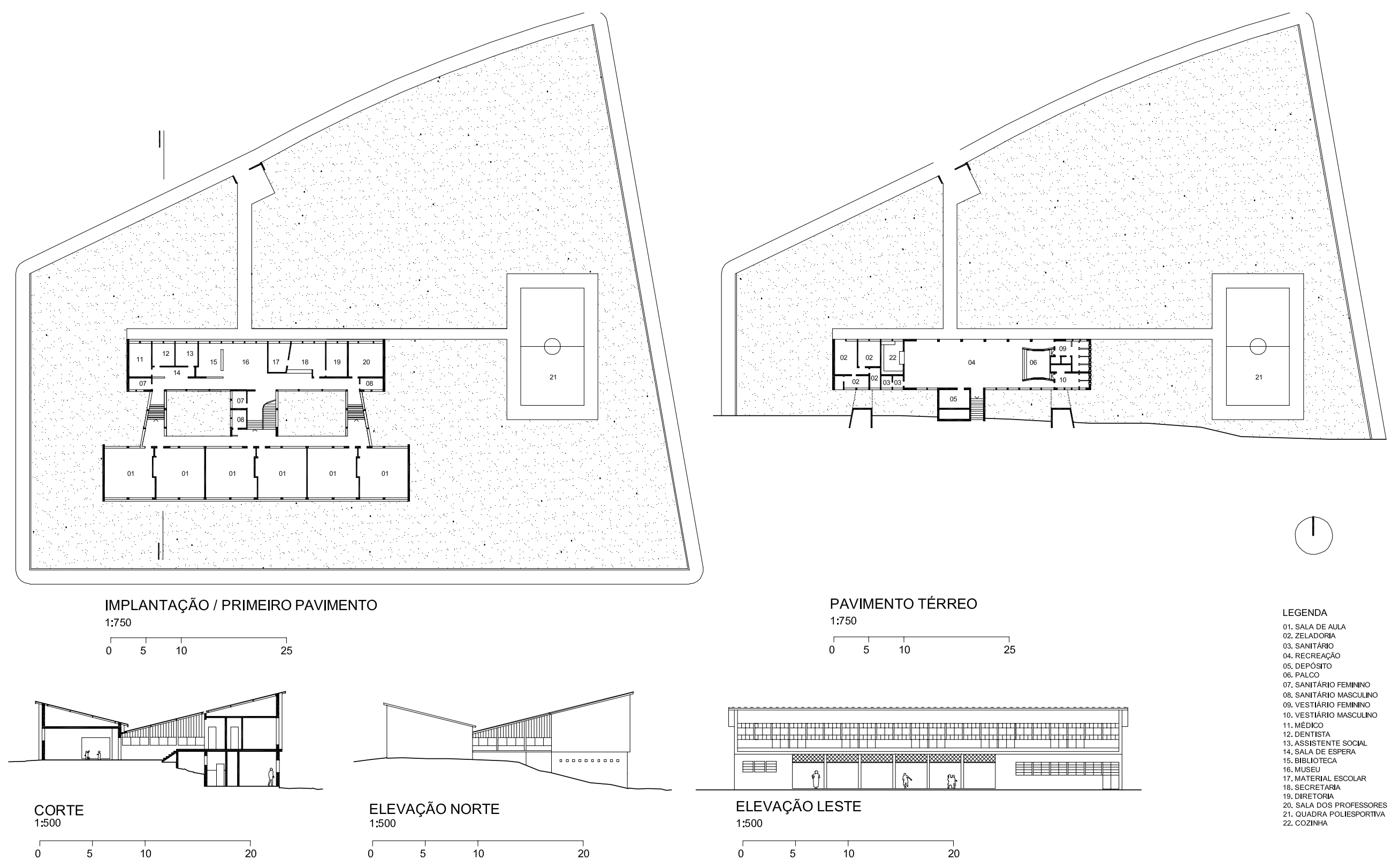

238 eE General antôNIO de SAMPAIO 


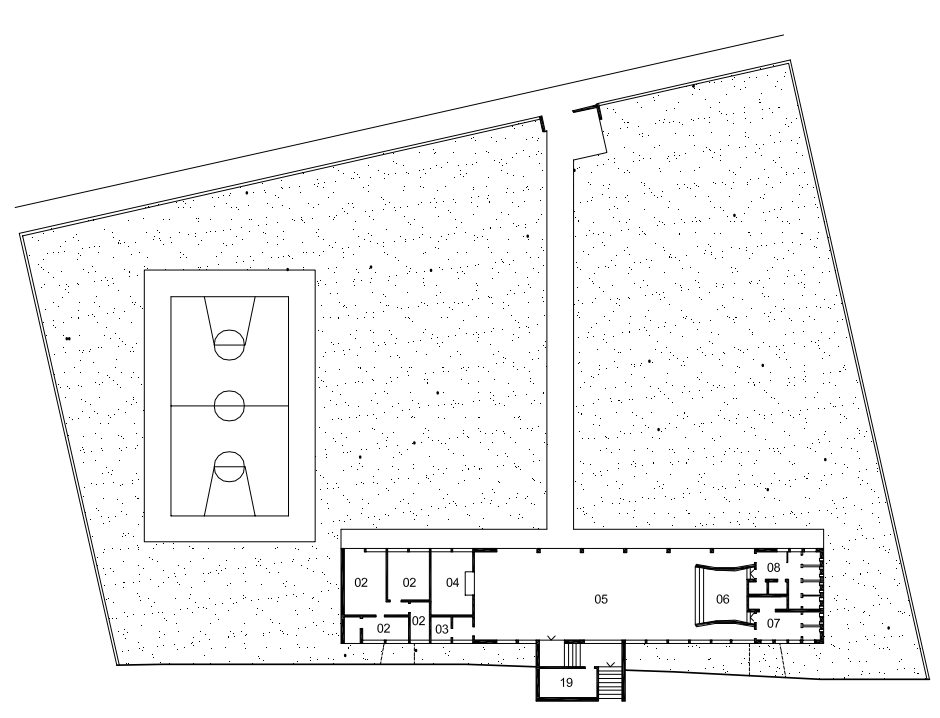

IMPLANTAÇÃO / TÉRREO 1:750
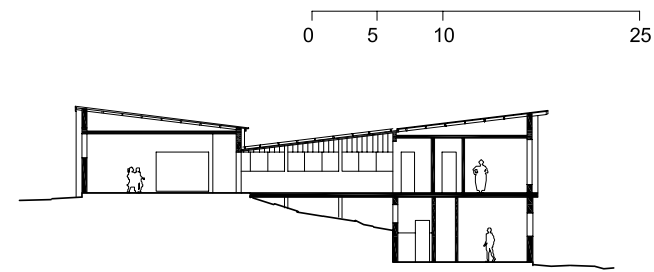

CORTE

1:500

\begin{tabular}{llll}
\hline & 1 & 1 & 20
\end{tabular}

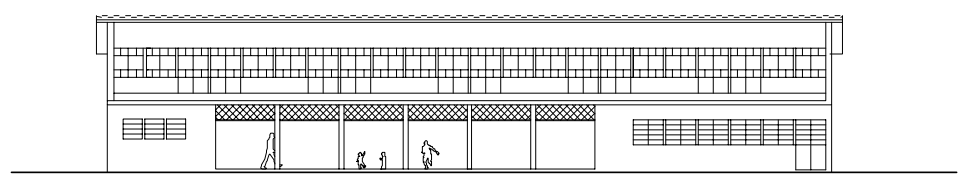

ELEVAÇÃO NORTE 1:500

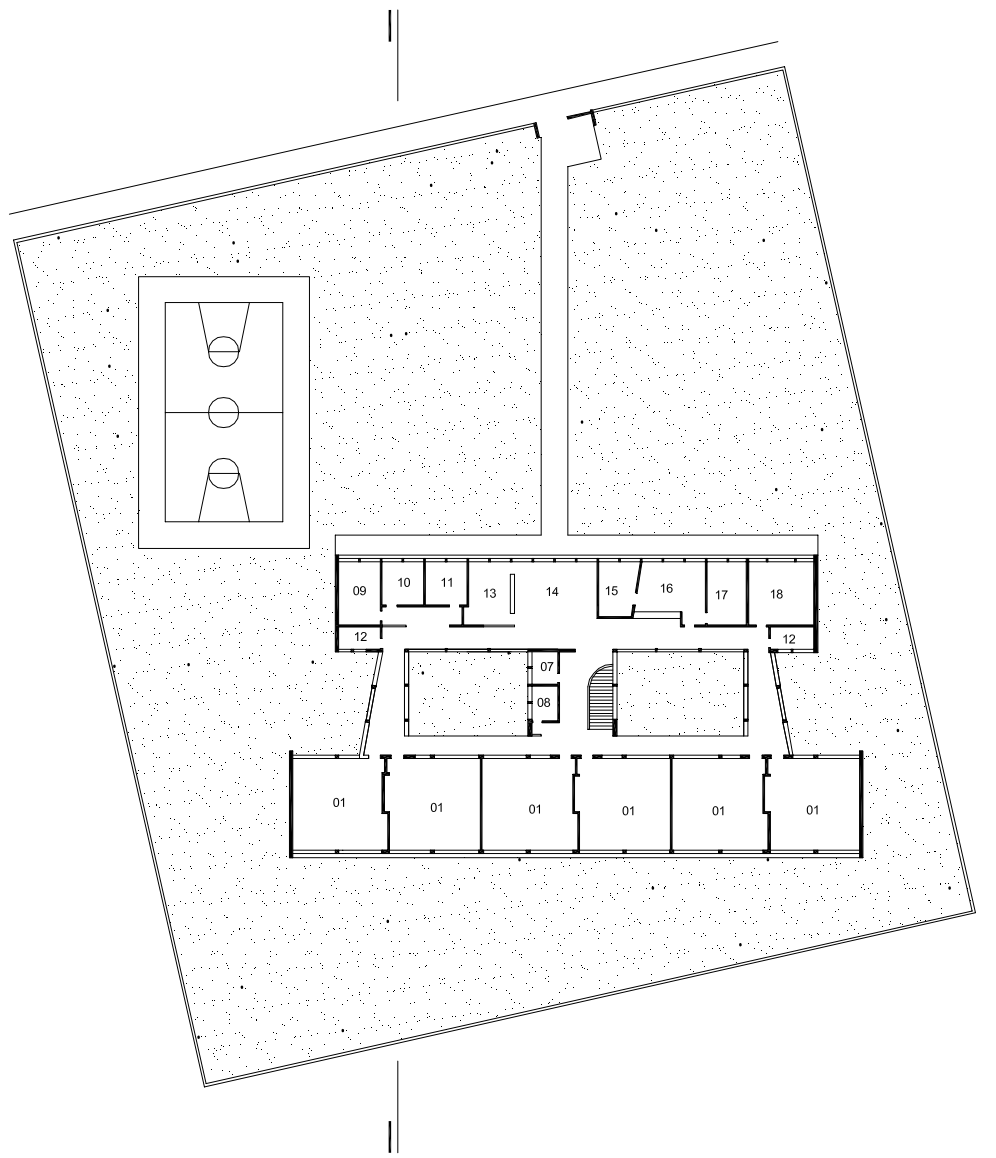

PAVIMENTO SUPERIOR

1:750

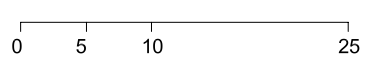




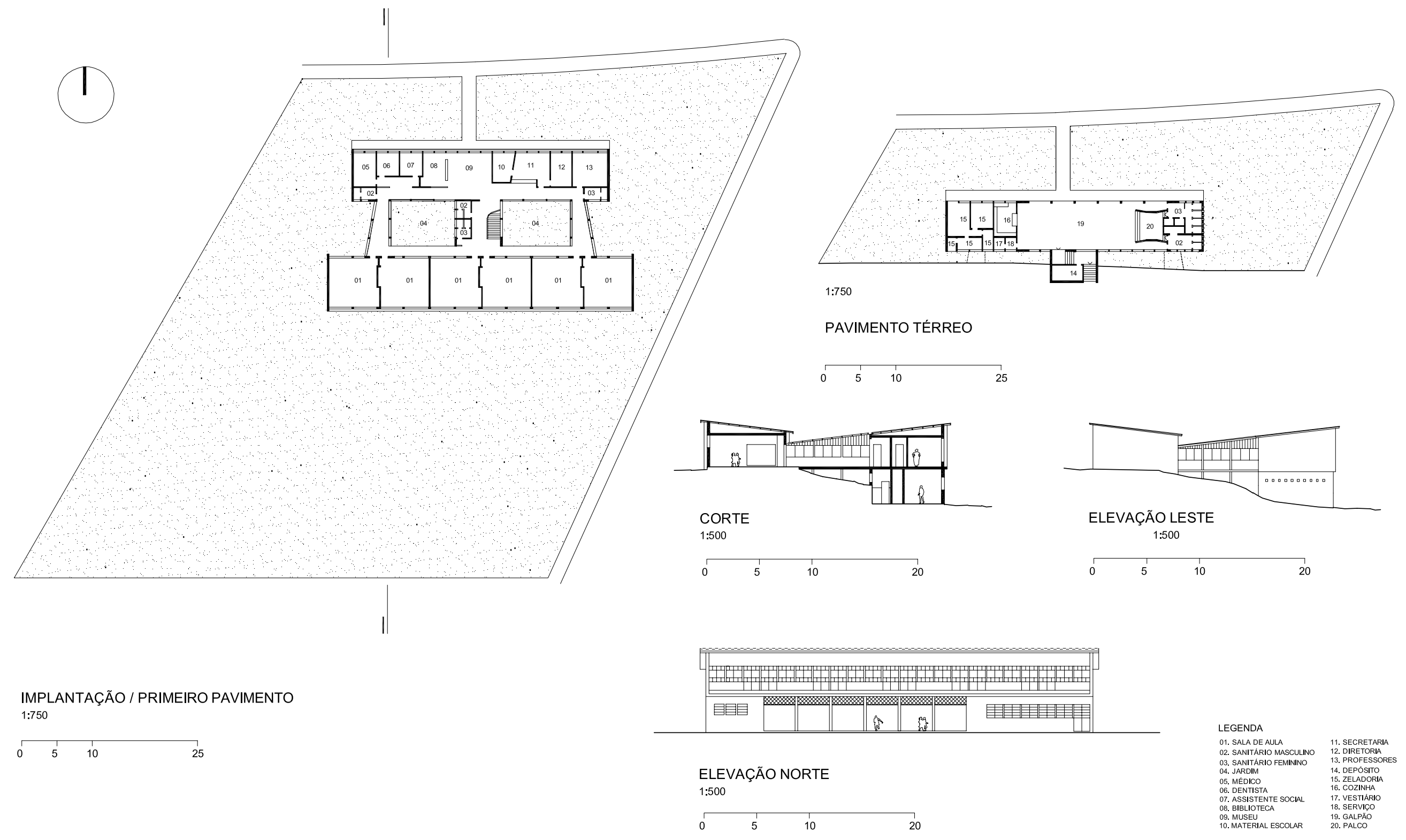




\section{EE Professor Pedro Voss (1951)}

Localizada no bairro da Saúde, essa escola assemelha-se às três anteriores. Sua variação volumétrica deve-se à topografia, ao formato do terreno e ao número de salas de aula exigido ( 12 salas). Esses fatores levaram à implantação de recreio coberto com abóbada, típica das escolas de Hélio Duarte.

Como nas outras escolas desse engenheiro, a iluminação bilateral é garantida através do pátio que separa o bloco administrativo (térreo) do bloco de ensino (2 pavimentos). A necessidade de garantir a iluminação bilateral obrigou a eliminação do corredor em frente às salas de aula e, como conseqüência, o acesso às 6 salas de aula do pavimento superior se dá através de 3 conjuntos de escada, uma escada para cada 2 salas de aula.

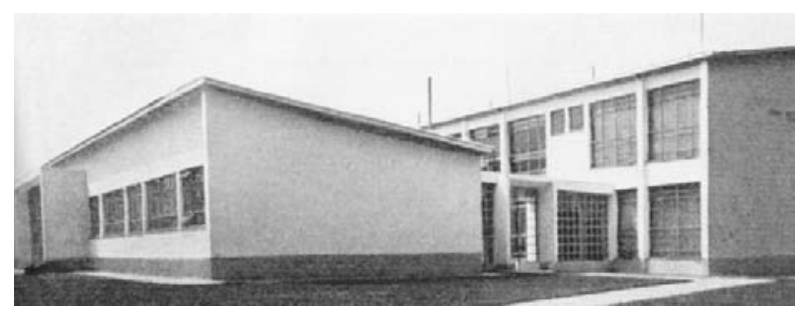

VOLUMETRIA CARACTERISTIICA DAS OBRAS DE ERNESTO MANGE

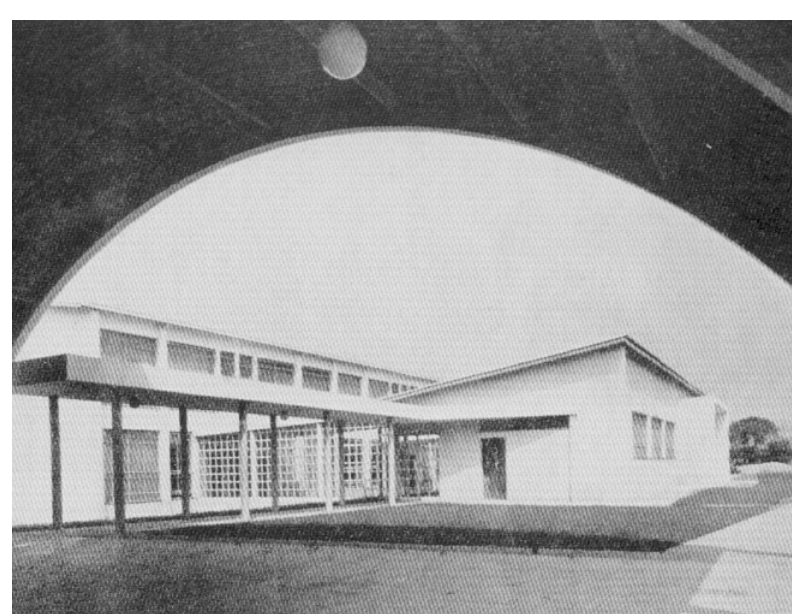

MARQUISE INTERLIGA BLOCOS FUNCIONAIS 


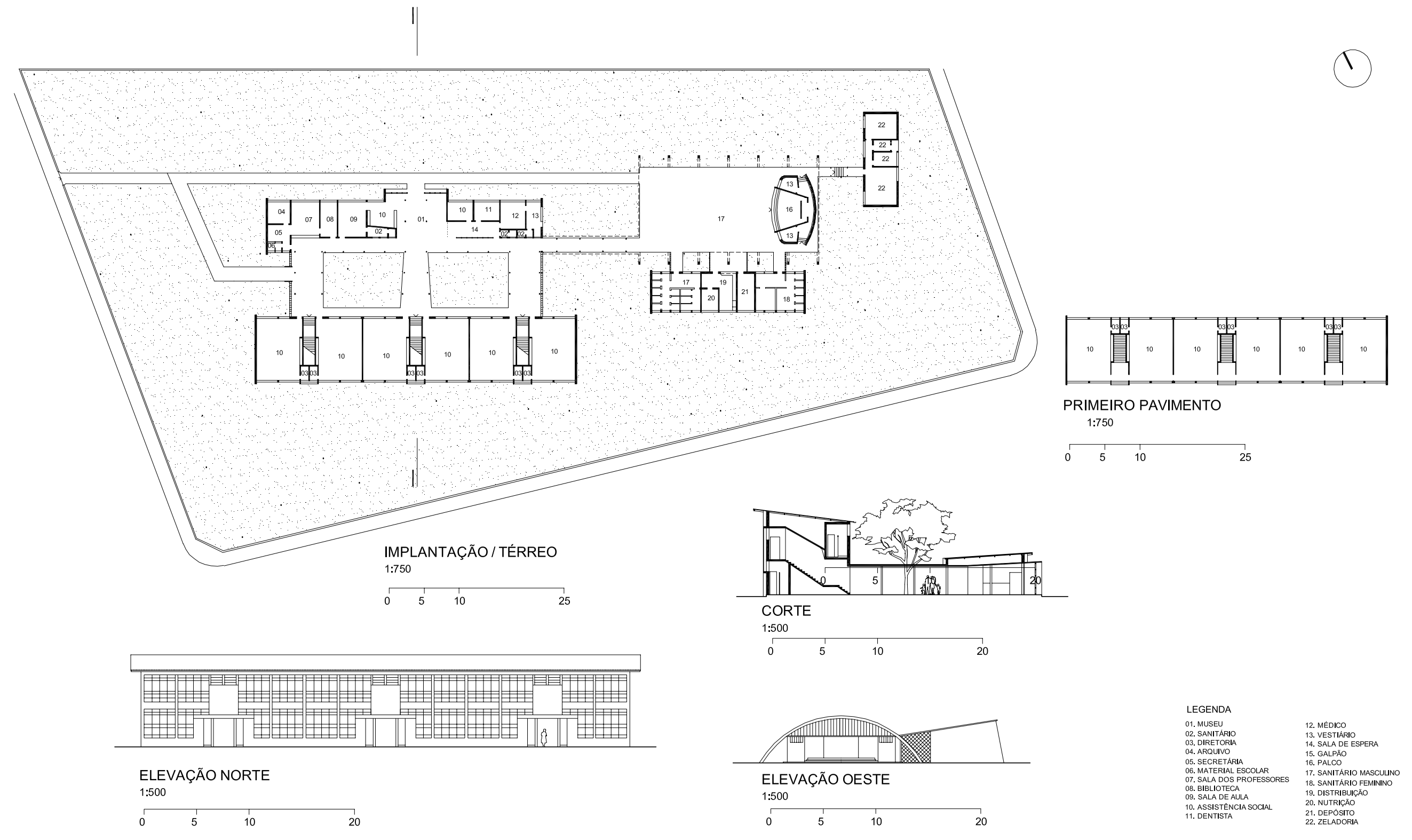




\section{EE Doutor Otávio Mendes (1951)}

Localizada no bairro de Santana, essa escola caracteriza-se pelo extenso programa arquitetônico que atendeu, no qual se inclui, além do programa básico, piscina, anfiteatro, salas ambientes para disciplinas específicas e salas de trabalhos manuais.

Sua implantação organiza-se em blocos funcionais de 2 pavimentos dispostos em forma de "U", abraçando a piscina. Um bloco térreo, que abriga os vestiários da área esportiva, serve de apoio a uma das pernas do " $U$ ", limitando o recreio coberto em pilotis. $\bigcirc$ conjunto caracterizado por paralelepípedos tem sua monotonia quebrada pelas variadas soluções de abertura para a entrada de luz nas circulações.

O bloco de ensino, o mais extenso, apresenta-se com salas nos dois pavimentos; o bloco administrativo localiza-se no pavimento superior, uma outra característica do engenheiro Ernest Mange em suas escolas: sob o setor administrativo uma área em pilotis define uma generosa entrada coberta para a escola.

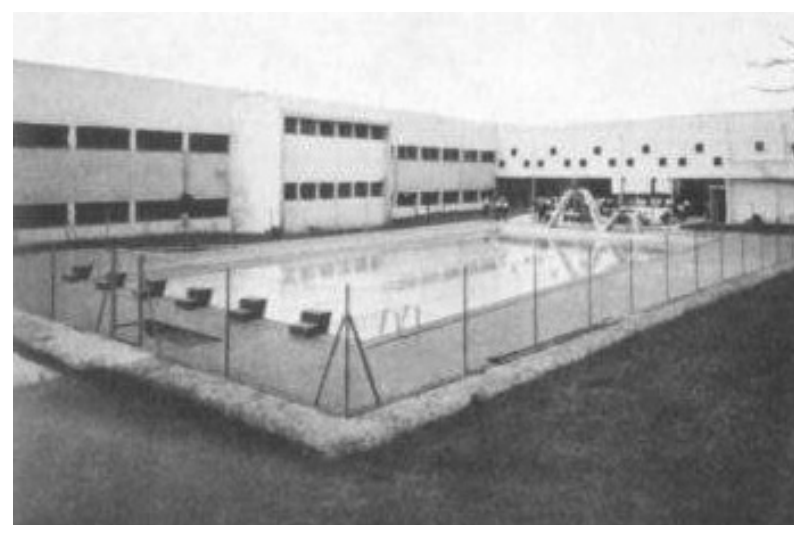

VISTA DO PÁTIO COM PISCINA

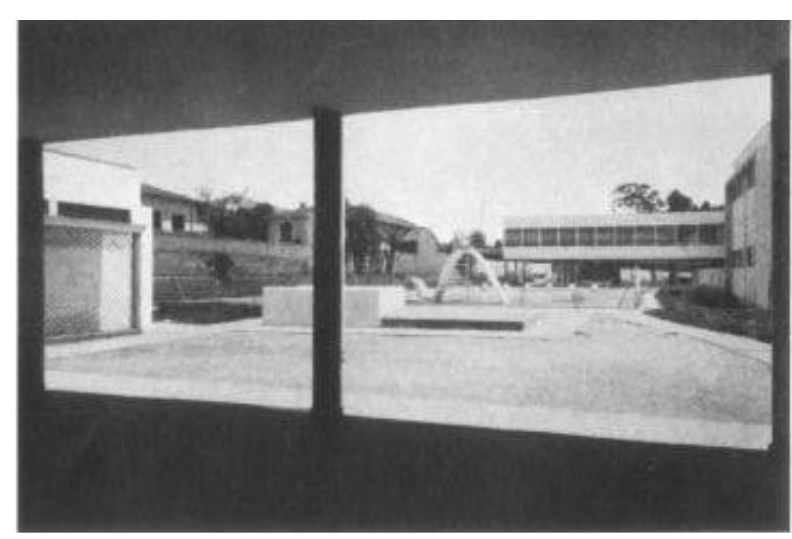

PILOTIS NAS DUAS PONTAS DÃO LEVEZA AO CONJUNTO 


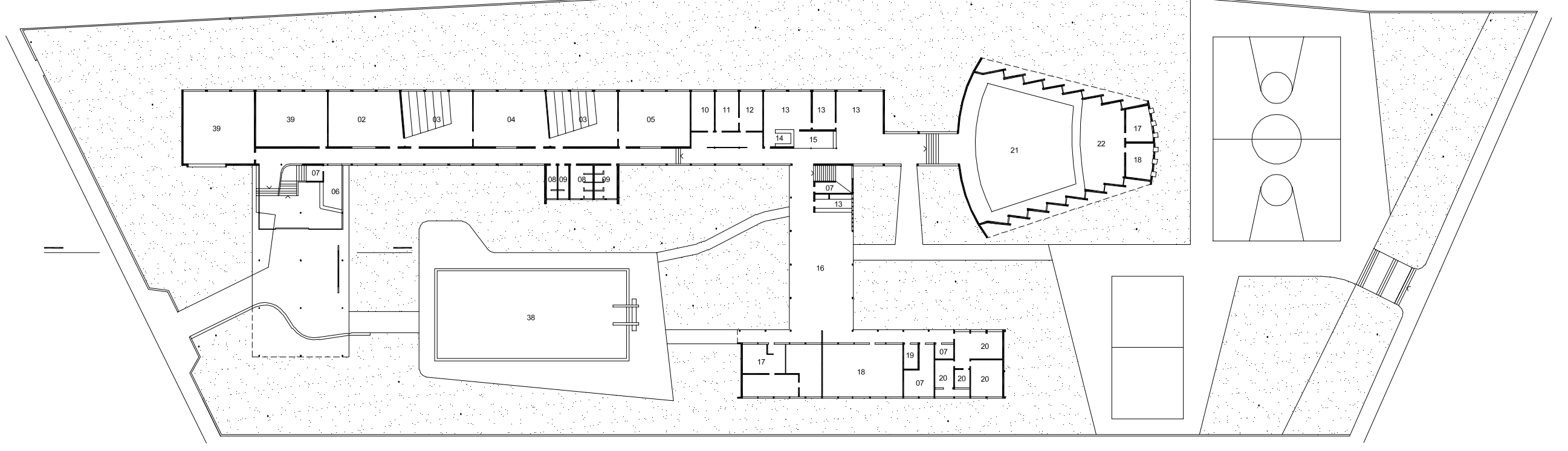

IMPLANTAÇÃO / TÉRREO

$1: 750$

\begin{tabular}{llll}
\hline & 1 & 1 \\
0 & 5 & 10
\end{tabular}

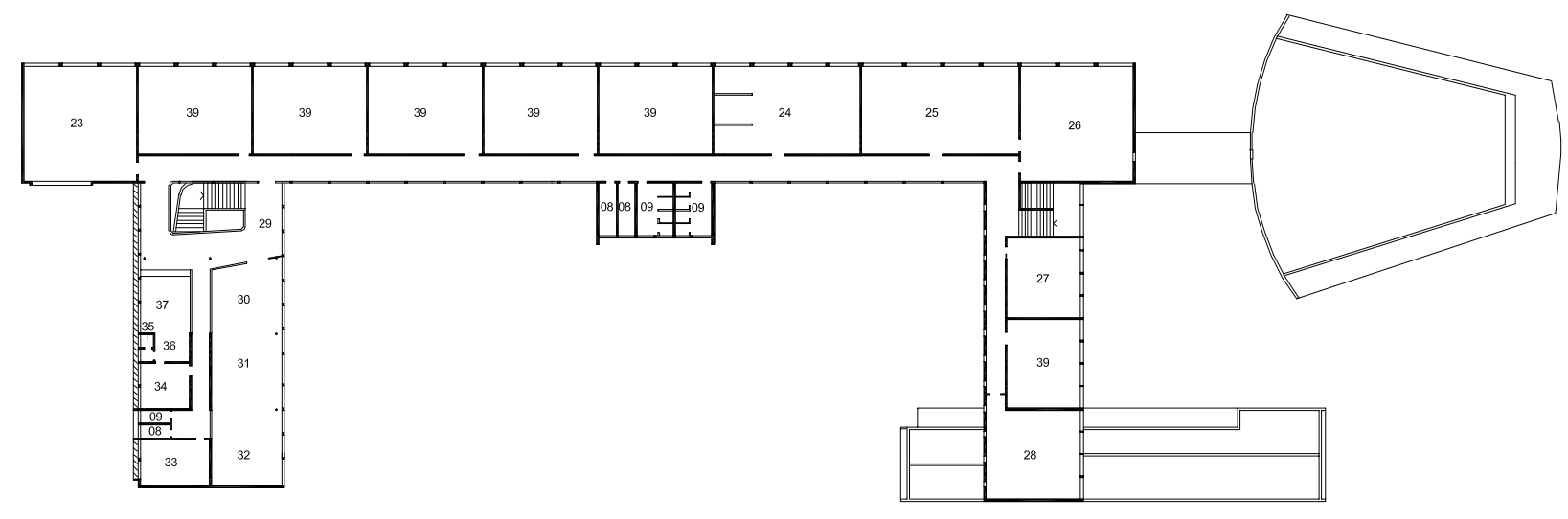

PRIMEIRO PAVIMENTO

1:750 25

\begin{tabular}{llll}
\hline & 1 & 10
\end{tabular}

LEGENDA

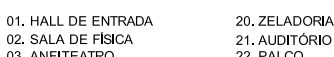

03. ANFITEATRO

04. SALA DE QUVIMICA
05. HISTORBAA NATURA

06. PORTARIA
07 . DEPOSITO

08. SANITARII MASCULINO
09. SAITARIIO FEMININO

11. MEDICO

12. ENFERMARIA
13. CANTIA

14. ARRUIVO
15. COPERATVA

16. GALPÃO

18. VESTIÁRIO FEMININO
19. VESTIARIO SERVENTES

24. SALA EE LINGUAS
25. SALA DE GEOGRAFA

25. SALA DE GEOGRAFA
26. SALA DE HISTORAA

27. TRABALHOS MANUAA FEMNINO

29. MUSEU

30. SALA DE LETURA
31. BIBLOOTECA

32. AALA DOS PROFESSORES
33. INSPETOR

34. DIRETTRA
35. SANITARIO DREETORA

7. SECRETARIA

38. PISCINA A ALA 


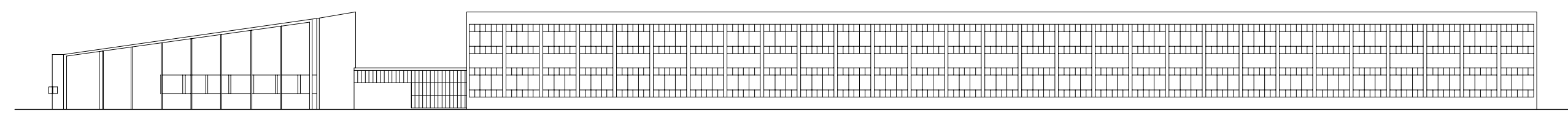

\section{ELEVAÇÃO NORTE}

1:500

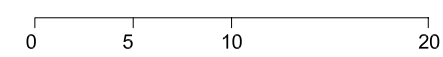

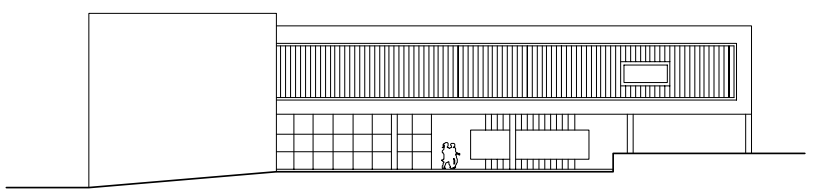

ELEVAÇÃO OESTE

1:500
1
$0 \quad 5$
20

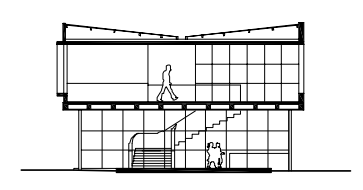

CORTE

1:500

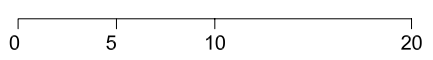




\section{ARQUITETO OSWALDO CORRÊA GONCALVES}

Dos arquitetos da equipe dirigida por Hélio Duarte, Oswaldo Corrêa Gonçalves é o que mais se aproxima da produção de seu diretor. Algumas escolas suas chegam a repetir os mesmos blocos funcionais das escolas de Hélio Duarte, de acordo com a racionalização proposta para orientar os trabalhos da equipe.

Durante os anos de 1950 e 1951, anos em que participou do $2^{\circ}$ Convênio

Escolar, produziu cinco projetos. Nesses projetos, duas escolas têm recreio abobadado e outras duas têm recreio em pilotis, sendo que uma delas em bloco único. Um último projeto tem recreio definido com cobertura em asa de borboleta.

A análise dos projetos do arquiteto Oswaldo Corrêa Gonçalves confirma depoimento do arquiteto Eduardo Corona (publicado na tese de doutorado de Mário Caldeira), ao descrever o ambiente de trabalho da equipe: um galpão sem divisórias possibilitava a todos os arquitetos acompanhar os trabalhos e idéias em desenvolvimento, fazendo com que as soluções caminhassem livremente pelos projetos em produção, em resposta à busca da melhor solução, independente de sua autoria.

Seguem as escolas: 


\section{EE Canuto do Val (1950)}

Localizada no bairro da Barra Funda, essa escola repete, em sua implantação, a articulação de três blocos funcionais independentes, interligados por marquises, soluções presentes nas obras do arquiteto Hélio Duarte, em que, o bloco administrativo, térreo, articula-se com o bloco de salas de aulas em 2 pavimentos e o recreio coberto abobadado, através de uma marquise. 


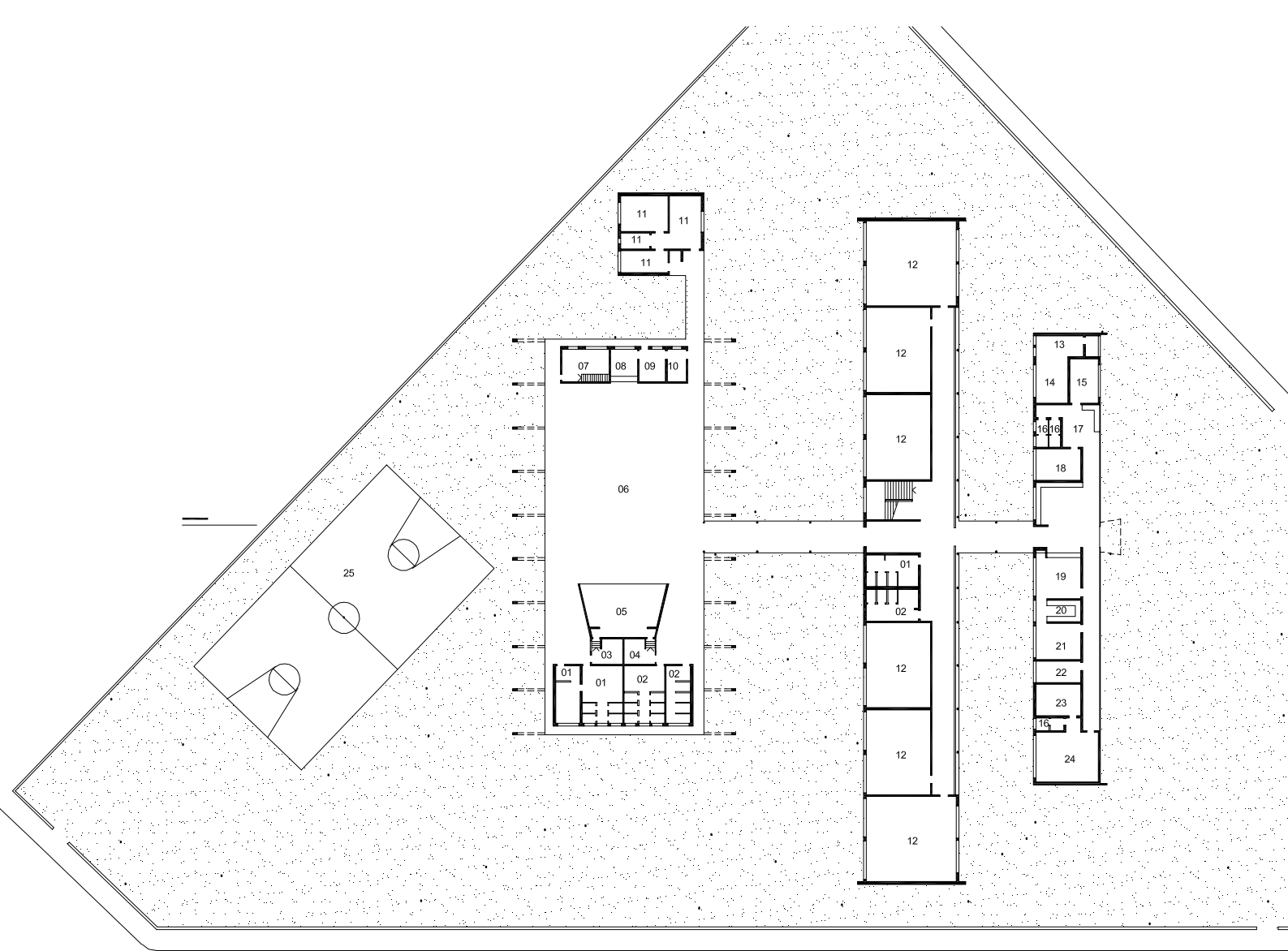

IMPLANTAÇÃO / TÉRREO

$1: 750$

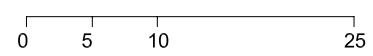

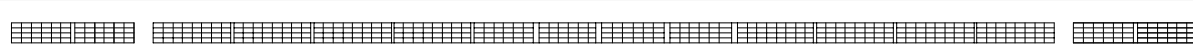

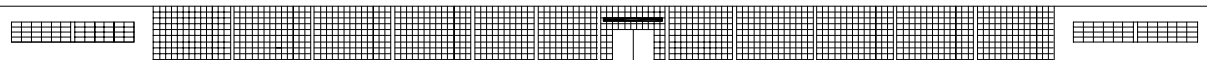

\section{FACHADA}

1:500

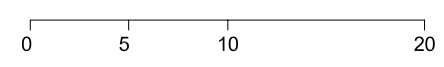

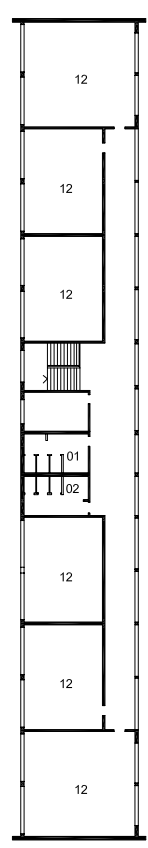

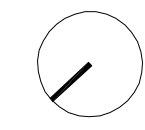

LEGENDA

02. SANITÁRIO FEMMININO

03. VESTIARIO MASCULINO
0.45 VESTIARIO FEMININO

05. PALCO

07. GALPAO
07. DEPSSITO

8.
09. DISTRRBUIGÁA
COZINHA

10.

12. ZELADORIA
13. SALDEEAULA
SERVENTE

13. SERVENTE
15. MEDICO
DENTISTA

SANITARIOS

17. SALA DE ESPEAA
18. SALA SOCIAL

19. SECRETARI
20. ARQUIVO

22. DIRETRR
MATRRAL ESCOLAR
SALA DE PROFESSO

24. BBBLIOECA ESOSOR
PRIMEIRO PAVIMENTO $1: 750$

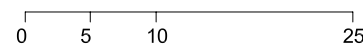

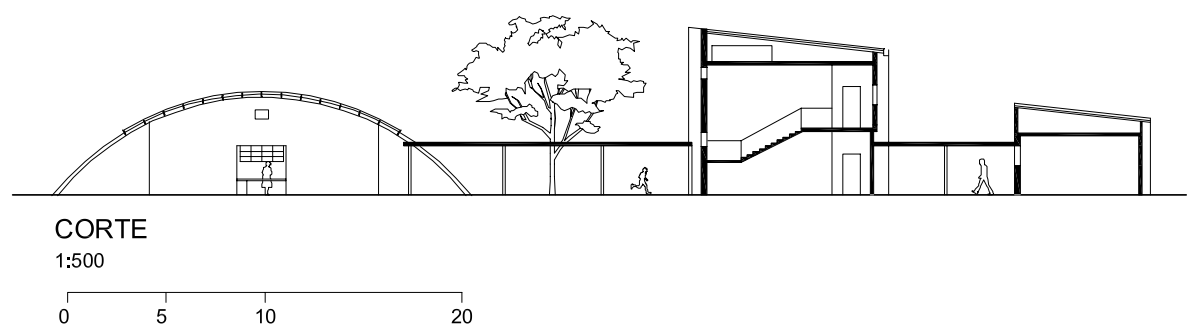




\section{EE Romeu de Moraes (1950)}

Localizada no Bairro da Lapa, sua implantação foi organizada a partir dos três blocos funcionais independentes articulados em forma de " $U$ ", também de acordo com a tipologia arquitetônica criada por Hélio Duarte para seus primeiros projetos. $\bigcirc$ bloco de ensino, de maior extensão, com salas de aula nos dois pavimentos, se articula com o recreio coberto abobadado e com o bloco administrativo, através de marquises de concreto. $\bigcirc$ bloco administrativo, em 2 pavimentos, abriga, no térreo, as funções burocráticas da escola e, no pavimento superior, os serviços sociais e de saúde, que as escolas ofereciam às crianças, de acordo com o programa arquitetônico mínimo do convênio escolar. 

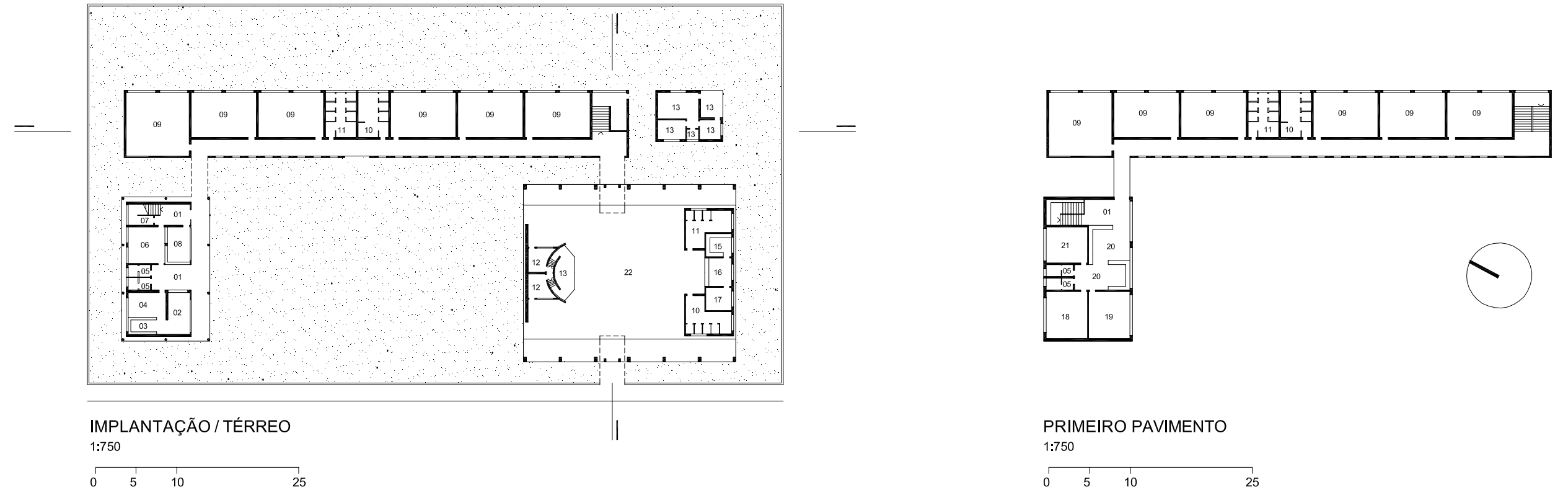

PRIMEIRO PAVIMENTO

1:750
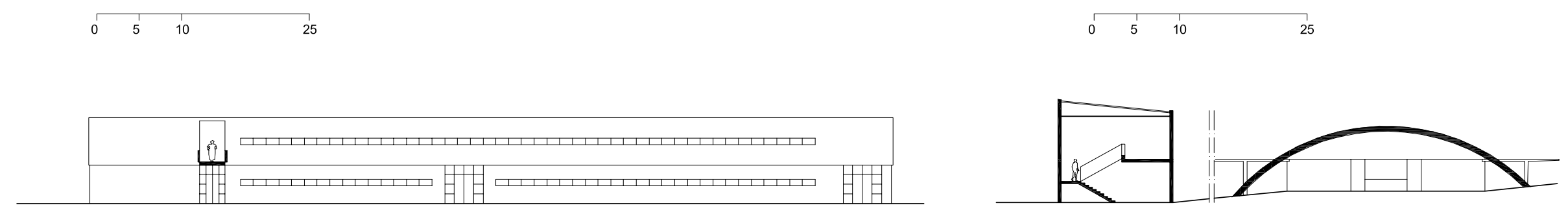

ELEVAÇÃO SUDOESTE

1:500

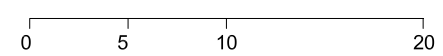

\section{CORTE}

1:500
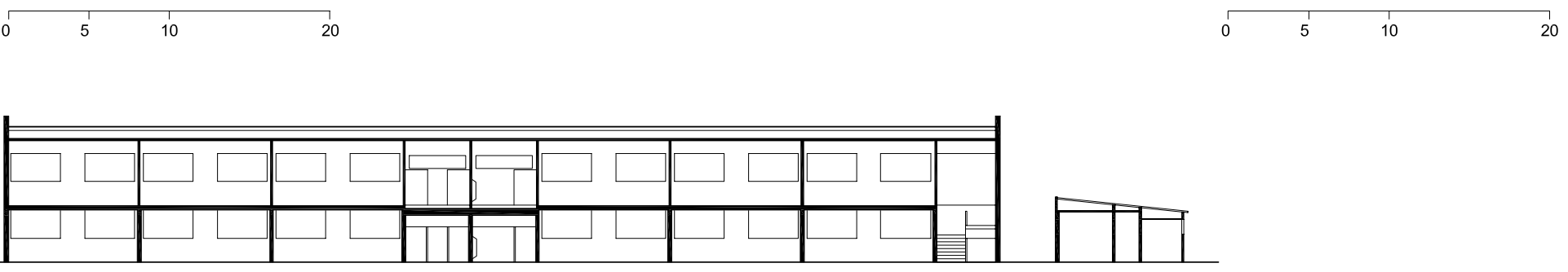

CORTE LONGITUDINAL

1:500

\begin{tabular}{llll}
\hline & 1 & 1 & 20
\end{tabular}

250 Ee ROMEU de MORAES 


\section{EE Pedro Taques (1950)}

Localizada no bairro de Guaianazes, essa escola, em sua implantação, aproveita habilmente o desnível do terreno e propõe dois blocos interligados por rampa, definindo uma volumetria final com cobertura em asa de borboleta, lembrando, assim, as soluções propostas pelo arquiteto Eduardo Corona. Seu recreio é coberto por uma das laterais dessa asa, enquanto seu bloco de salas de aula distribui-se em 2 pavimentos permitindo ampliação em um dos lados. 


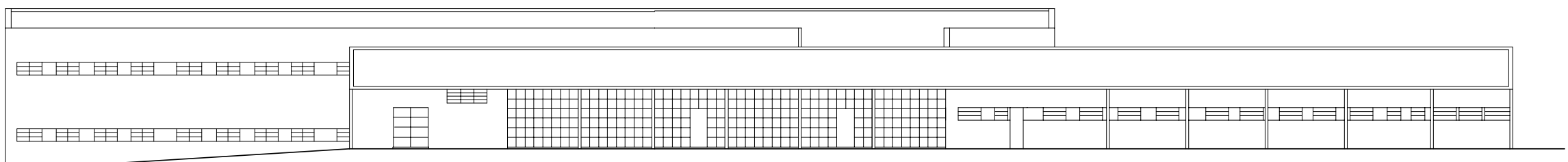

ELEVAÇÃO SUL

$1: 500$

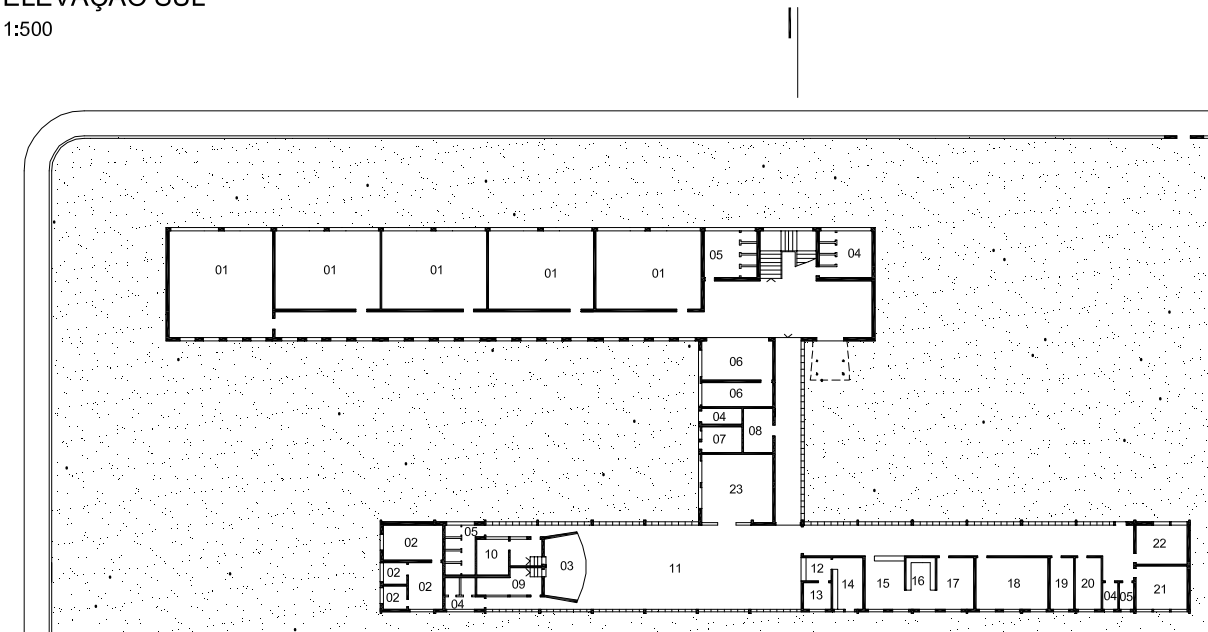

IMPLANTAÇÃO/ TÉRREO

1:750

\begin{tabular}{ll|l}
\hline 0 & 5 & 10
\end{tabular}

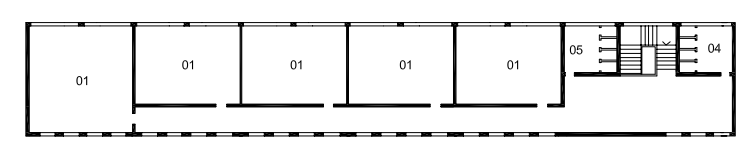

PRIMEIRO PAVIMENTO

1:750

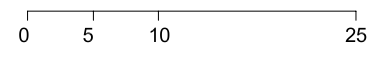

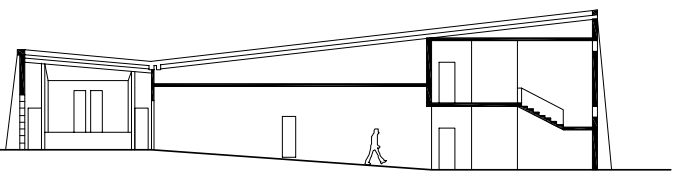

CORTE

1:500

\begin{tabular}{llll}
\hline & 5 & 10 & 20
\end{tabular}
LEGENDA

01. SALA DE AULA
02. ZELADORIA
0.3. PALCO

04. SANITARIO MASCULINO
05. SANITARIO FEMININO

BiBLIOTECA

7. SALA DE SERVENTE
ALMOXARIFADO

9. VESTIÁRIO MASCUINO

12. DISTRIBUUÇĀA 


\section{EE Carlos Escobar (1950)}

Localizada no bairro do Tatuapé, essa escola apresenta seu programa arquitetônico organizado em um bloco de 2 pavimentos, com recreio em pilotis. No pavimento térreo, além do recreio coberto, encontramos o setor administrativo e, no pavimento superior, todas as 12 salas de aula (pela análise do projeto e da área disponível de terreno, não é compreensível essa solução). 


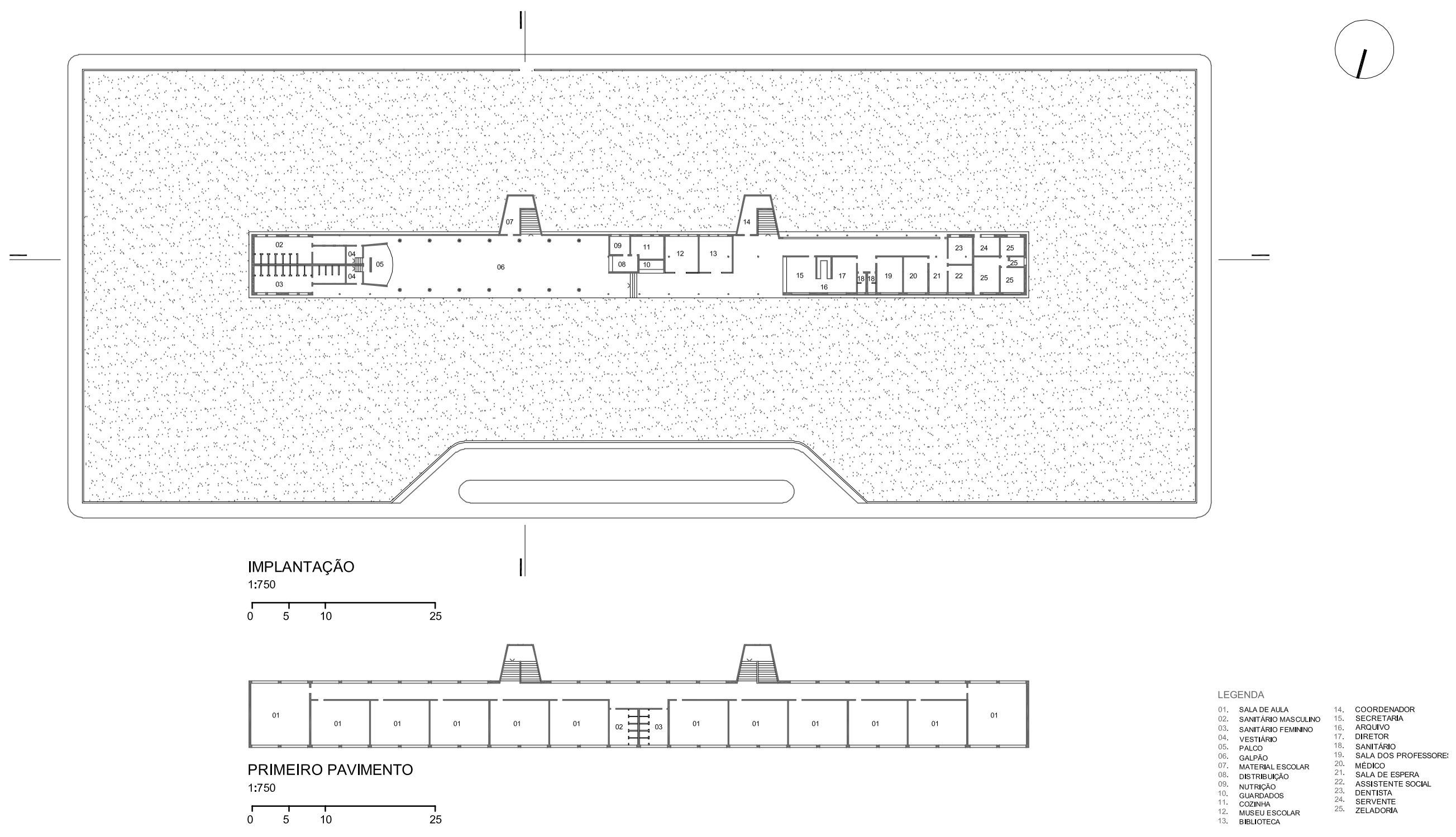



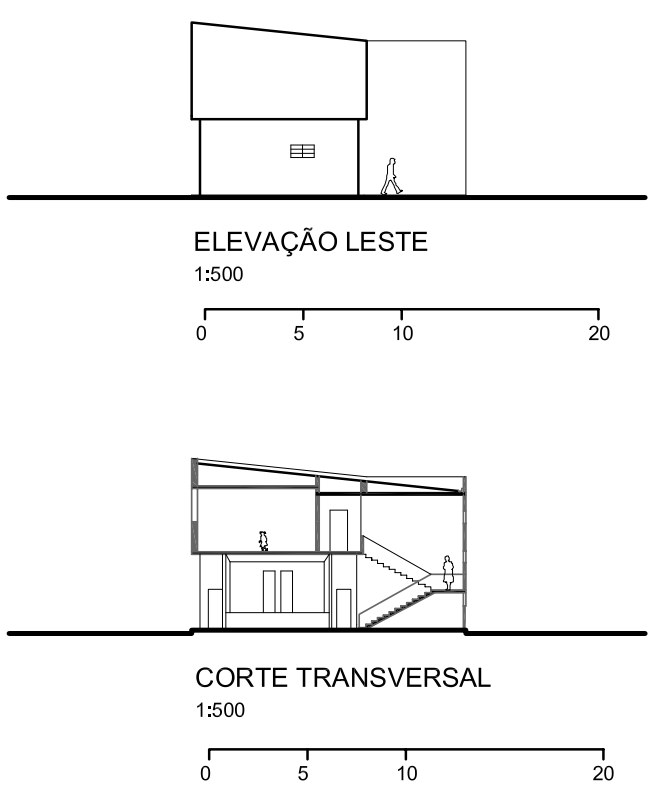

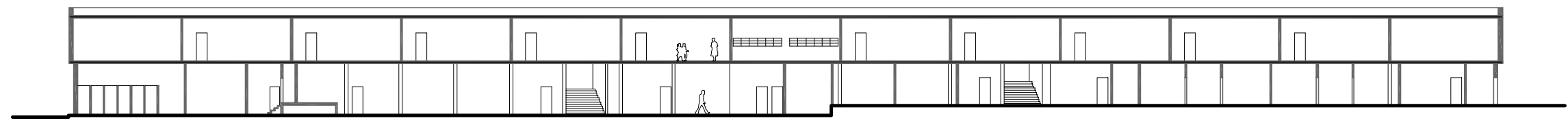

CORTE LONGITUDINAL

1:500

\begin{tabular}{lll}
\hline & 1 & 10
\end{tabular}

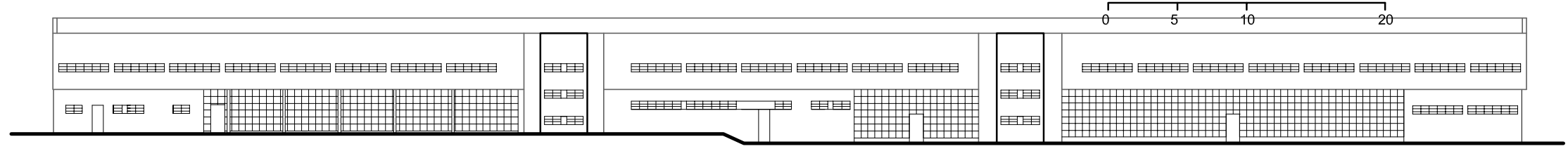

ELEVAÇÃO SUL

1:500

\begin{tabular}{llll}
\hline & 1 & 1 \\
0 & 5 & 10
\end{tabular} 


\section{EE República do Paraguay (1951)}

Localizada no bairro de Vila Prudente, essa escola é a única do $2^{\circ}$ Convênio Escolar a incluir em seu programa arquitetônico uma quadra coberta. $\bigcirc$ terreno, com topografia em aclive, levou o arquiteto a organizar sua implantação em dois níveis e a escolher a rampa como solução para o acesso à escola.

O projeto arquitetônico organizou a distribuição dos ambientes em torno de um pátio central quadrado, delimitado, em seus dois lados ortogonais à rua, pelo pilotis que abriga o recreio coberto de um lado e o refeitório do outro. Nos dois lados do quadrado, paralelos à rua, o pátio é delimitado, de um lado, pelo bloco administrativo e, pelo outro, por outra área em pilotis. A quadra fica um pé-direito mais alta do que o pátio central, mesma cota de nível das salas de aula. 

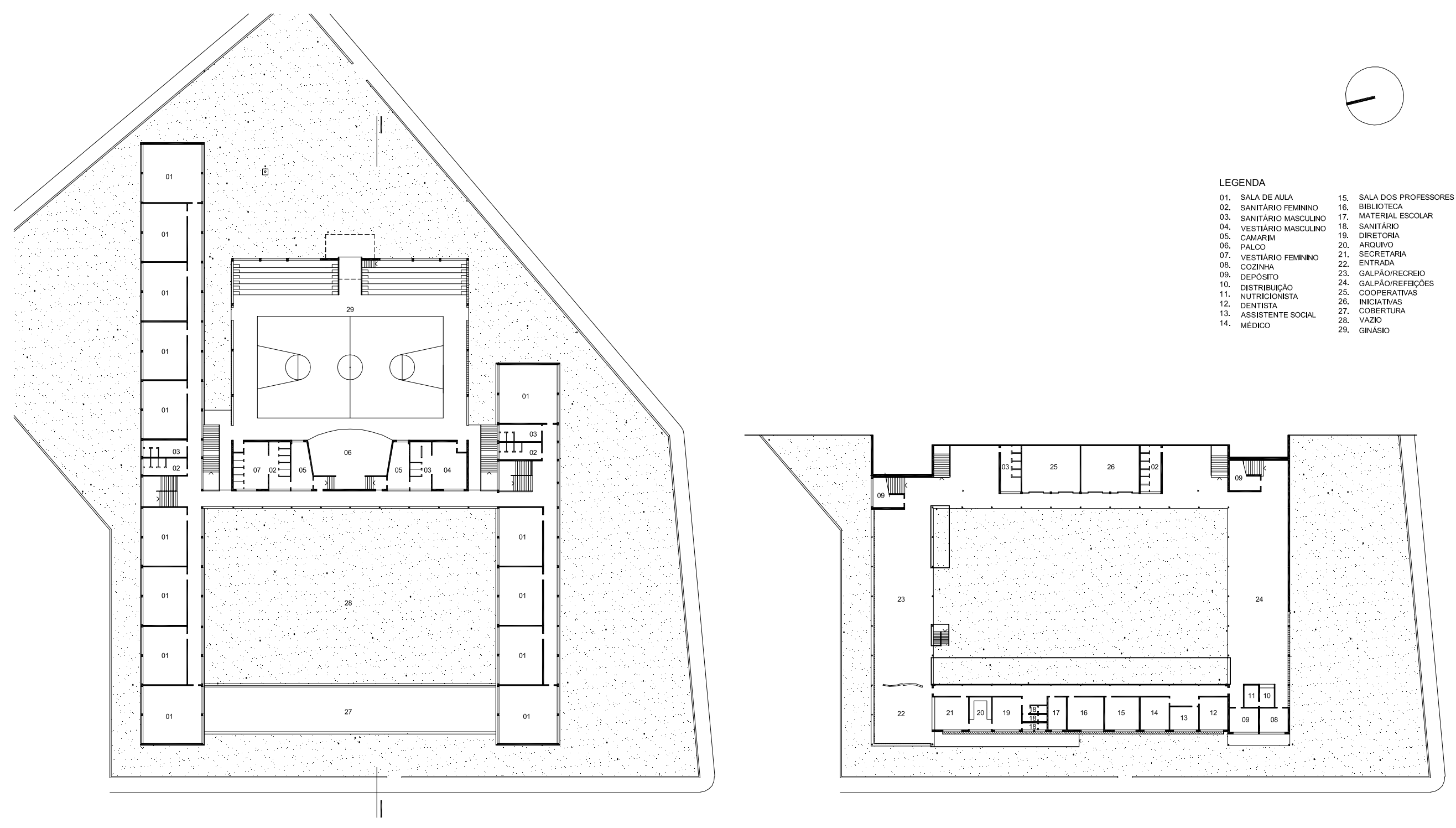

IMPLANTAÇÃO / PRIMEIRO PAVIMENTO

$\begin{array}{llll}1: 750 & & \\ 0 & 5 & 10 & 25\end{array}$

PAVIMENTO TÉRREO

$\begin{array}{lrll}1: 750 & \\ 0 & 5 & 10\end{array}$ 


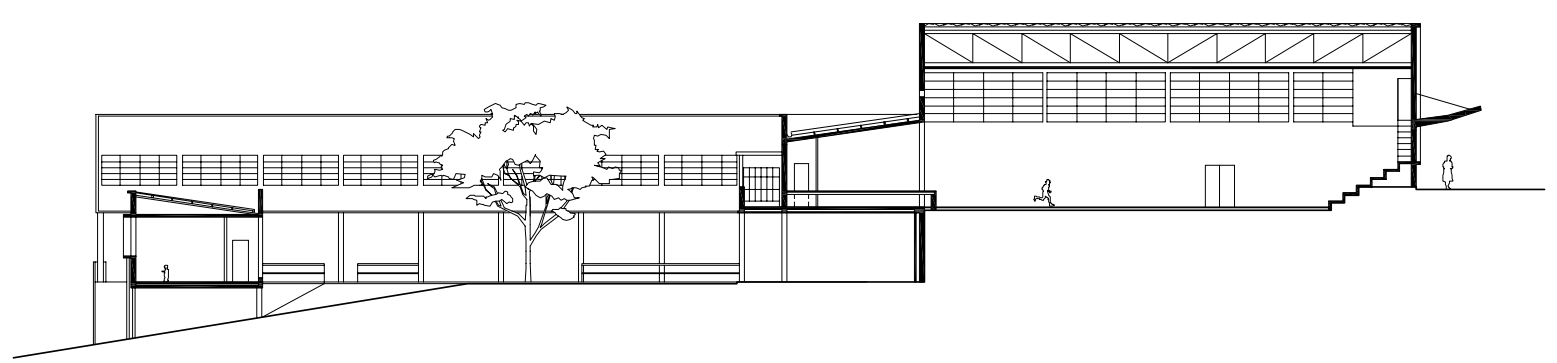

CORTE
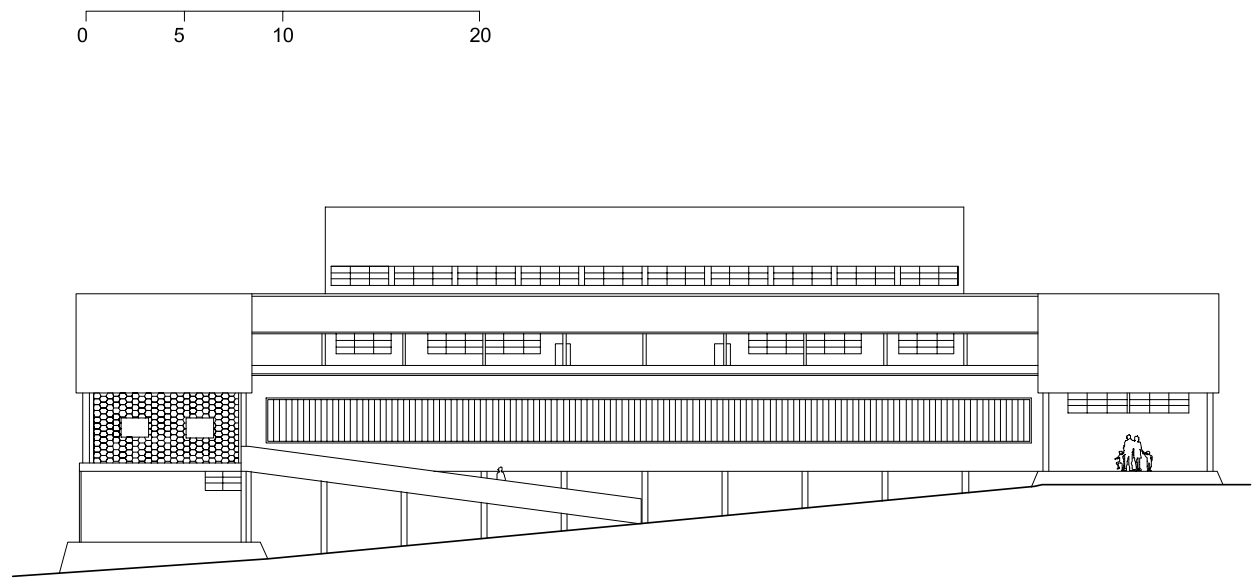

ELEVAÇÃO OESTE

1:500

\begin{tabular}{llll}
\hline & 1 & 10
\end{tabular} 


\section{ARQUITETO JUVENAL WATEGE JÚNIOR e}

\section{ARQUITETO ALUÍSIO ROCHA LEÃO}

Cada um dos arquitetos assinou somente um projeto arquitetônico de edifício escolar do $2^{\circ}$ Convênio, sendo respectivamente, as escolas: 


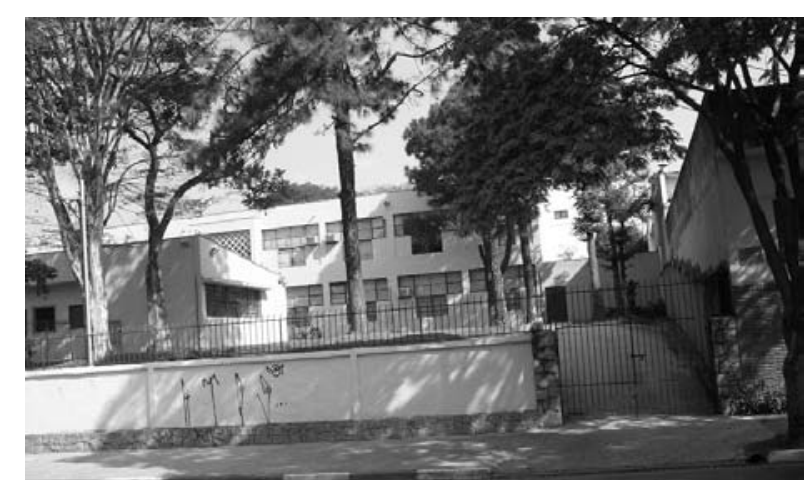

FACHADA PRINCIPAL EE THOMAZ GALHARDO

\section{EE Thomaz Galhardo (1952)}

Localizada no bairro da Lapa, essa escola revela uma implantação que tem como critério a ocupação do terreno a partir de seu perímetro; assim, o recreio com sua cobertura definida por telhado de uma só água aproxima-se da divisa do terreno, de maneira a liberar área para a recreação descoberta.

Há três blocos funcionais: o administrativo, térreo, e o de ensino com 2 pavimentos, acoplam-se ao de recreio, coberto, através de marquises. Um quarto bloco diferencia esse programa arquitetônico dos programas das demais escolas. Trata-se de um bloco térreo, chamado de vocacional: era preocupação da Comissão Executiva do Convênio Escolar o futuro dos estudantes, quando terminassem o ensino primário; assim, foi preparado um ambiente para a orientação dos estudantes na escolha de uma profissão. 

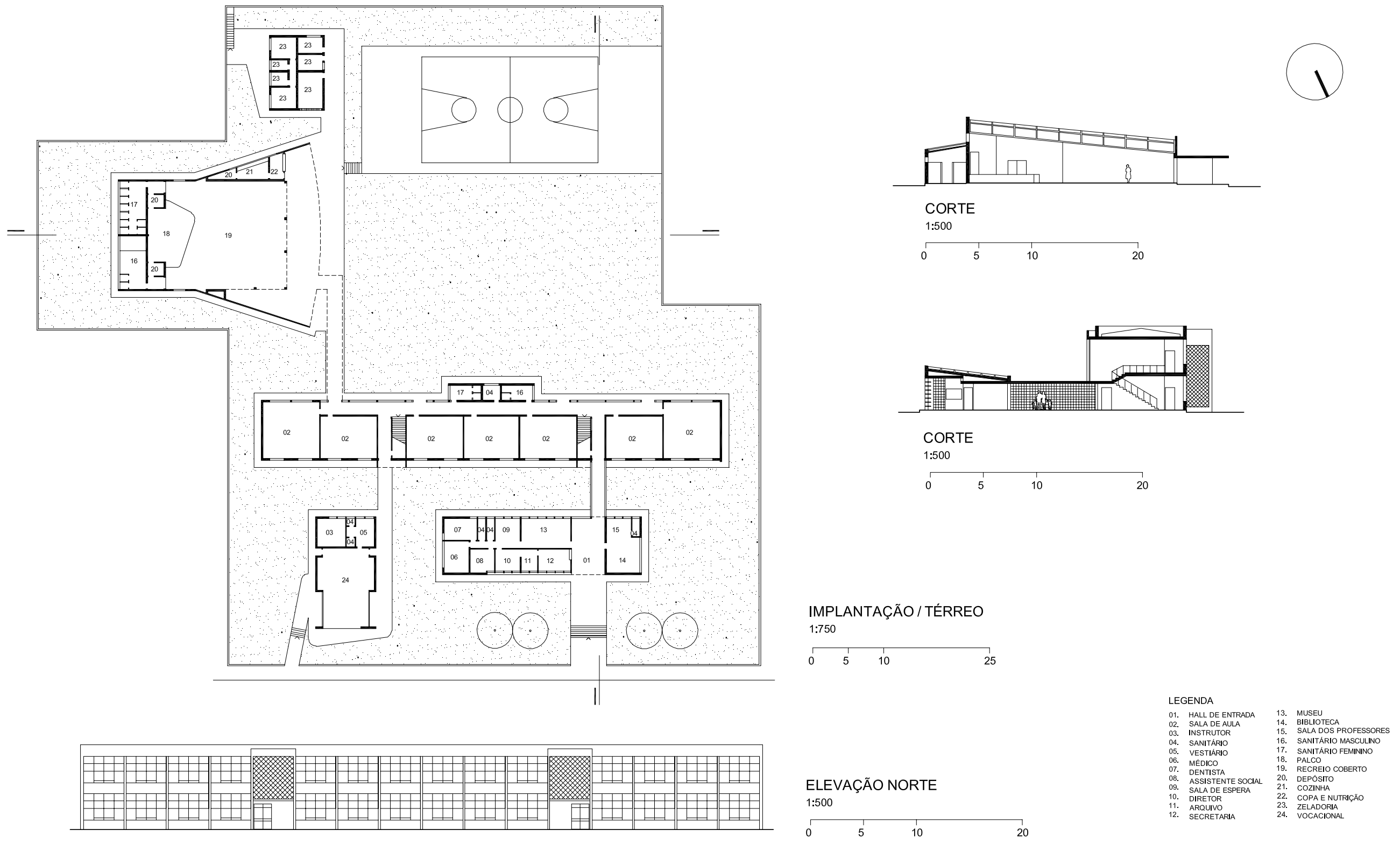


\section{EE Regente Feijó (1952)}

Localizada no bairro da Freguesia do Ó, em terreno de pequenas dimensões, essa escola tem seu programa arquitetônico caracterizado por três setores funcionais (ensino, recreação e administrativo) abrigados em um único volume com 2 pavimentos. O recreio coberto está localizado no térreo, em área de pilotis, ao lado do bloco administrativo; as sete salas de aula, por sua vez, estão no pavimento superior. 

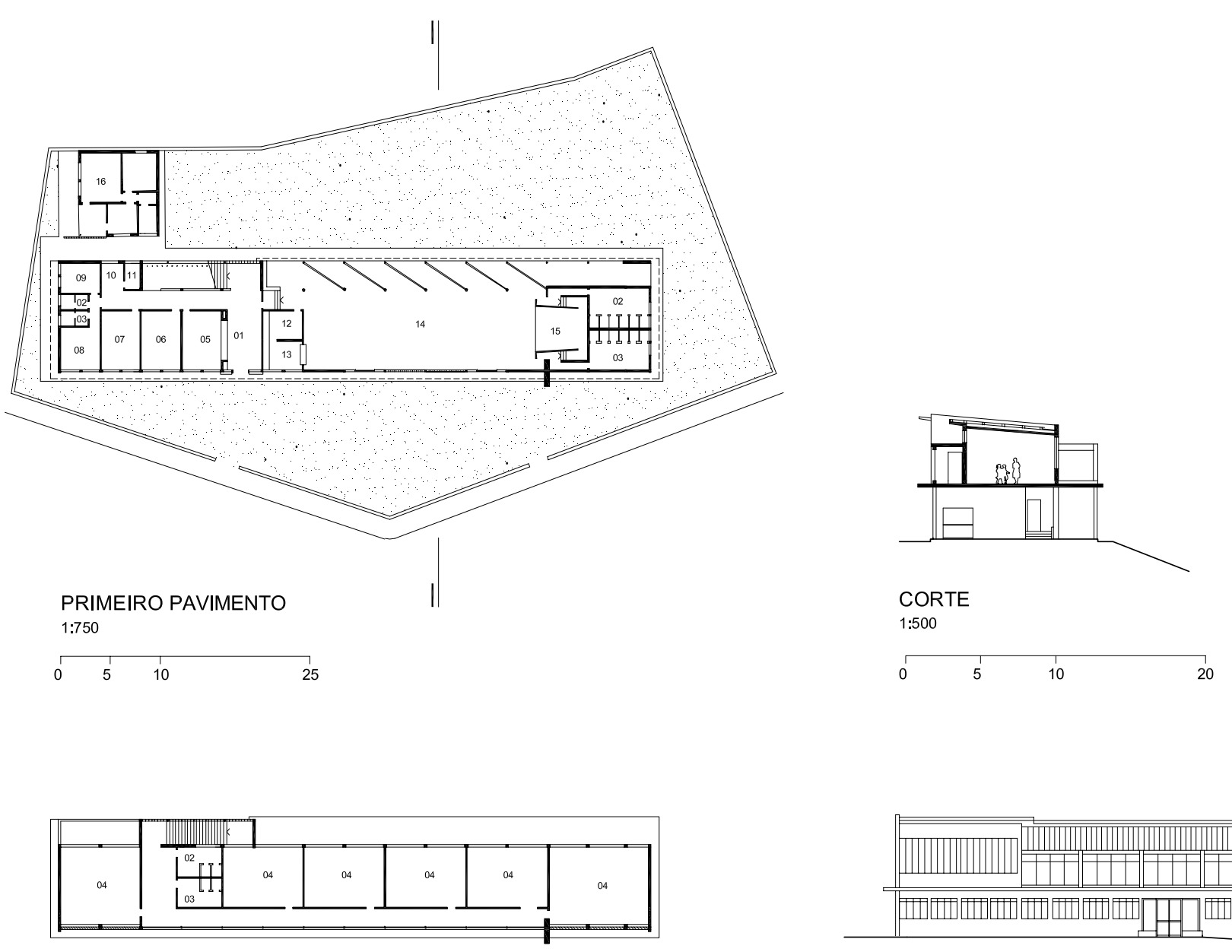

IMPLANTAÇÃO

1:750
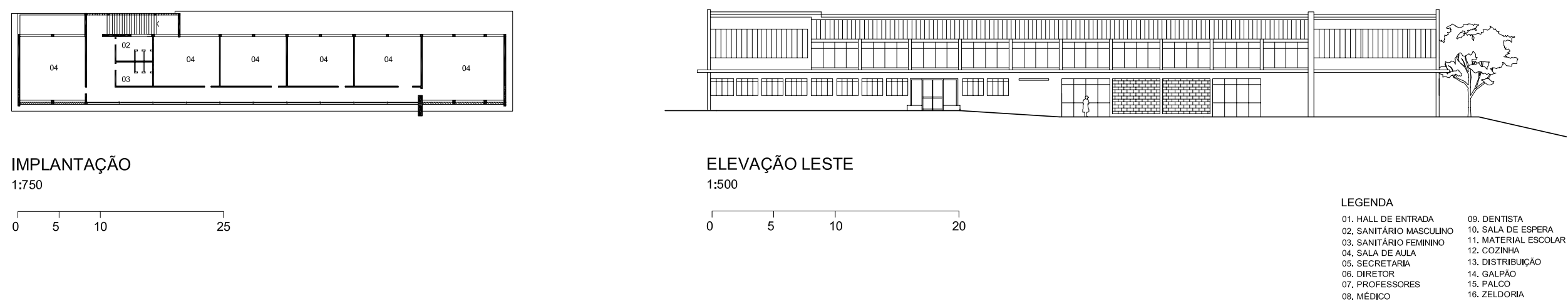


\section{OBRAS DE AUTORES NÃO IDENTIFICADOS}

O conjunto de obras do $2^{\circ}$ Convênio Escolar é facilmente identificado pela coerência de seu resultado formal, fruto dos princípios que guiou o desenvolvimento dos projetos, na equipe dirigida pelo arquiteto Hélio Duarte.

Vimos, também, que houve a possibilidade de manifestações individuais, em função da diversidade de situações, que os diferentes lugares da cidade propuseram como desafios aos arquitetos, e do experimentalismo, em resposta às inovadoras idéias que passaram a fazer parte dos novos programas arquitetônicos aplicados nas escolas do convênio.

Do conjunto de 52 escolas, 15 projetos não têm autoria declarada; assim, apresentaremos esta seqüência de projetos sem autoria definida, usando como critério o partido adotado para a implantação dos edifícios (blocos articulados ou bloco único) e seu partido volumétrico, a partir da definição da cobertura do recreio coberto (abóbadas, pilotis e plano inclinado)

\section{a) Blocos articulados com recreio em abóbada:}

Dos quinze projetos sem autoria definida, sete projetos adotaram a implantação a partir da articulação de blocos funcionais independentes (de ensino, de recreação e de administração), conectados através de marquises e com o recreio coberto por abóbada. Desses sete projetos, seis repetem os blocos administrativos térreos e blocos de ensino em 2 ou 3 pavimentos. 
Como podemos verificar, a tipologia determinada por Hélio Duarte foi aplicada de forma a não se identificar vontades pessoais, mas sim soluções econômicas e adequadas às diretrizes colocadas para uma escola voltada para a criança e inserida na cidade, de modo a desempenhar seu papel de equipamento comunitário.

Fazem parte desse grupo as escolas:

EE Professor Isaltino de Mello (1949) - bairro de Santo Amaro EE Professor Colombo de Almeida (1950) - bairro da Casa Verde EE Júlio Pestana (1952) - bairro do Tucuruvi EE Paulo Setúbal (1952) - bairro do Limão EE Dona Zalina Rolim (195I) - bairro da Vila Matilde EE Alfredo Bresser (1950) - bairro da Casa Verde EE Frei Gaspar da Madre de Deus (1950) - Osasco 


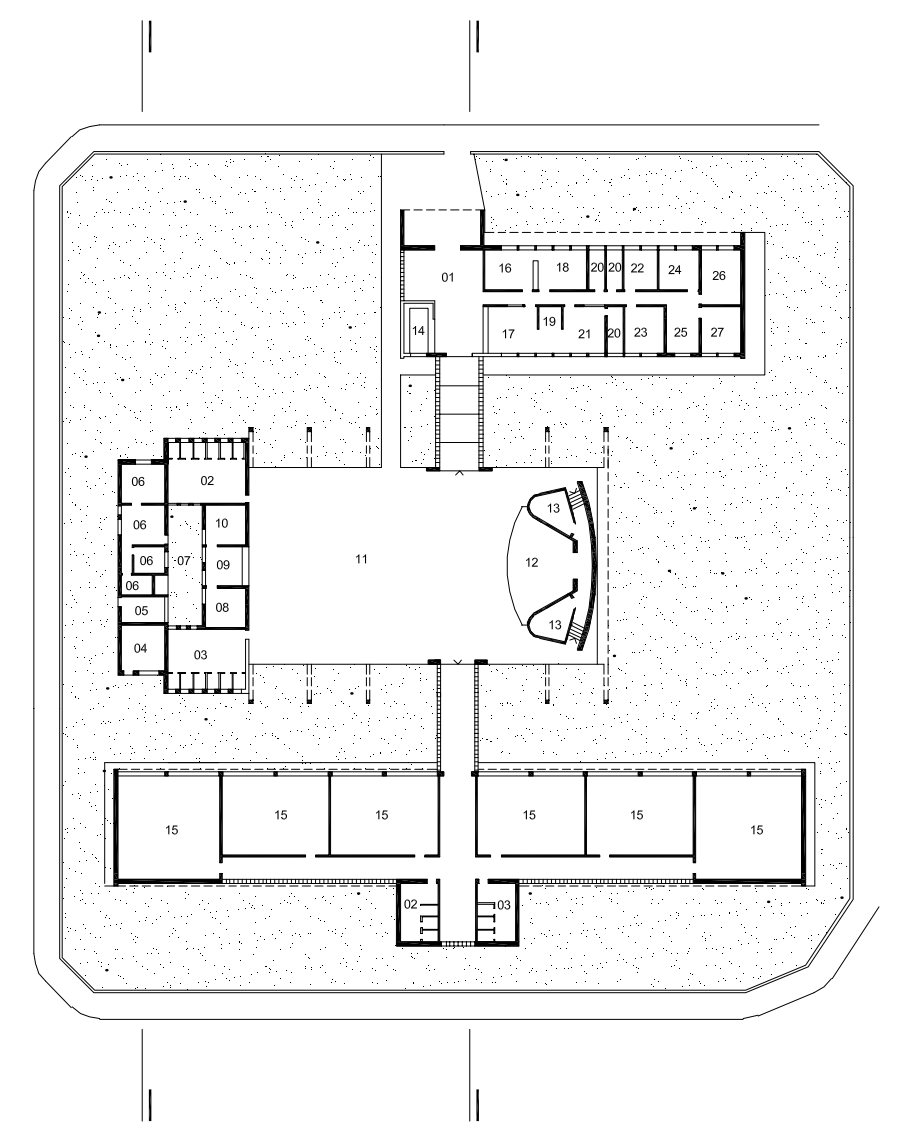

IMPLANTAÇÃO / TÉRREO 1:750

\begin{tabular}{llll}
\hline & 1 & 10 & 25
\end{tabular}

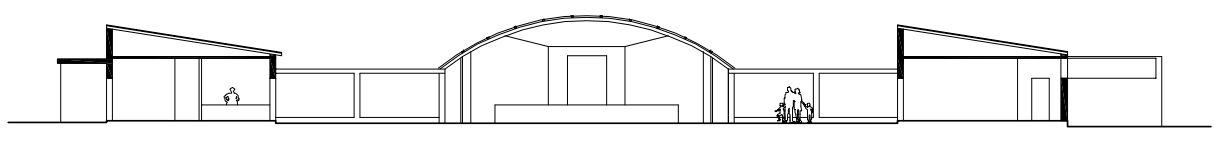

CORTE LONGITUDINAL

1:500

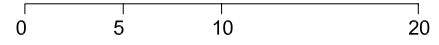

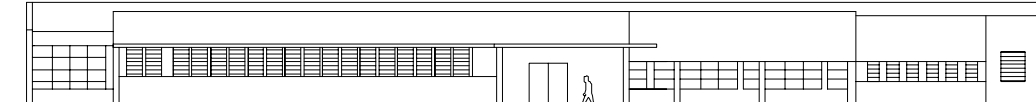

ELEVAÇÃO SUL
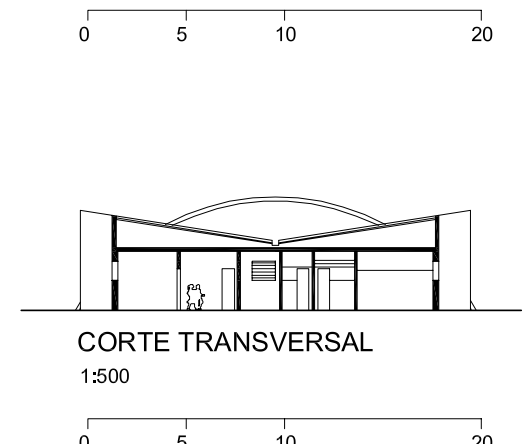

LEGENDA

01. HALL DE ENTRADAEMUS

03. SANITARIO FEMININO

05. DEPOSITO
06. SERENTE
06 ZELADORIA

06. ZELADORIA
07. PATEO

08. COZINHA
09. DISTRBBICAO
10. NUTPICISA

D. DISTRIBUICAO
10. NUTRCIONISTA
11. GALPAO

11. GALAÁO

13. VESTIARRI
14. GUARDADOS

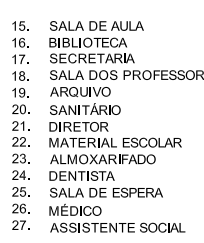



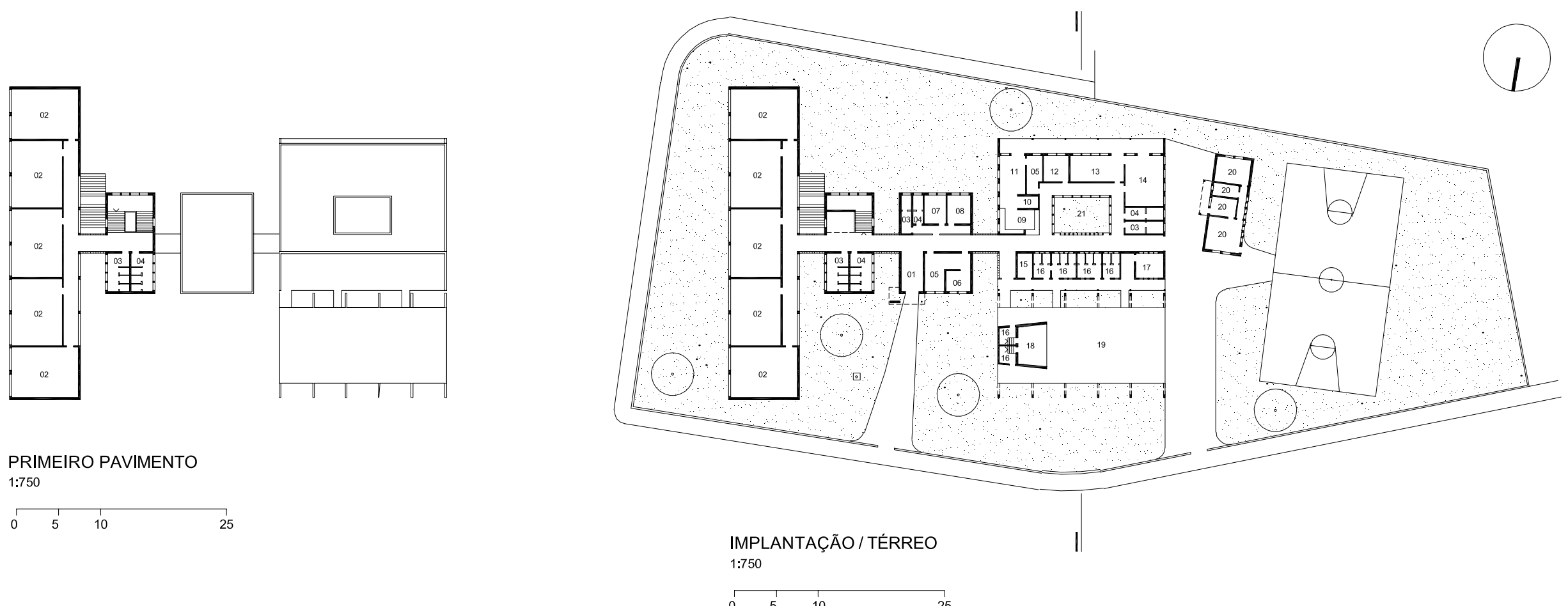

PRIMEIRO PAVIMENTO

1:750

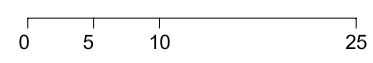

1:750

\begin{tabular}{llll}
\hline & 5 & 10
\end{tabular}

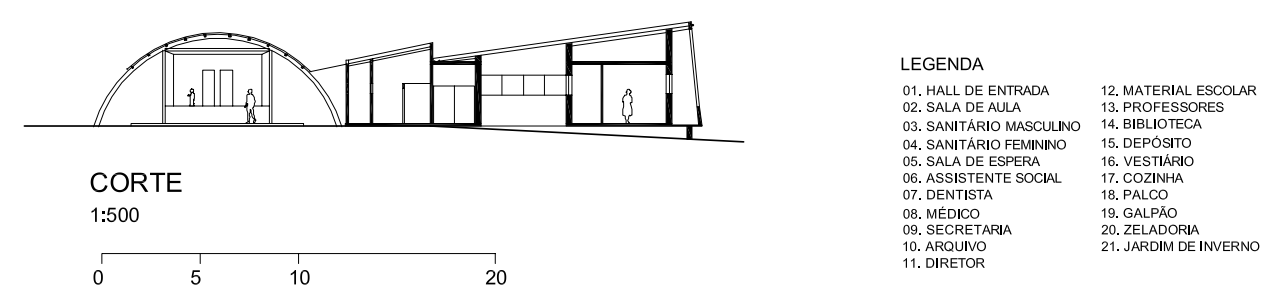




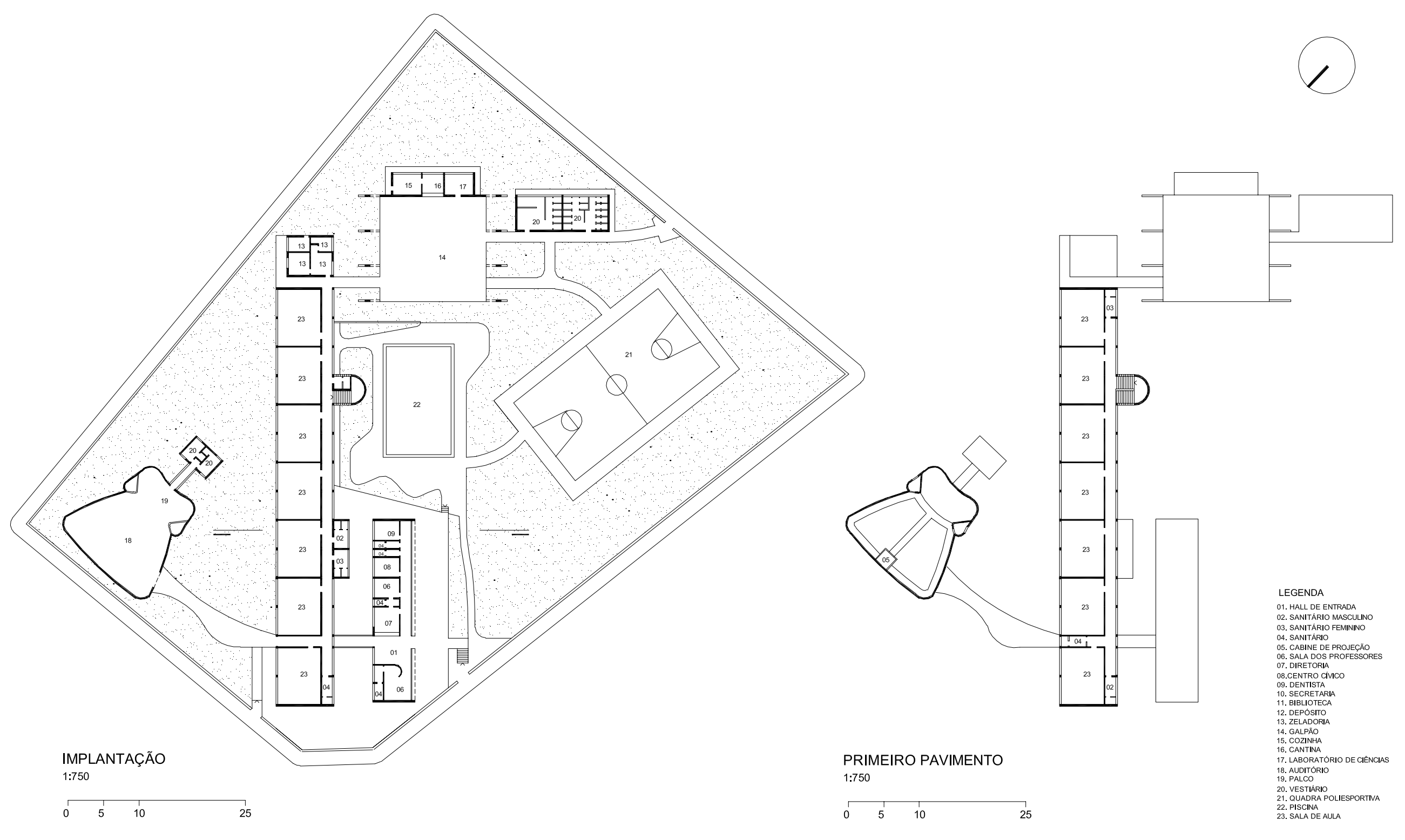




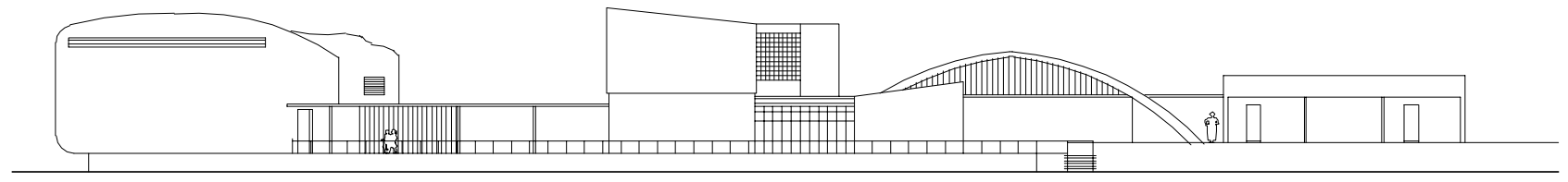

ELEVAÇÃO NORDESTE 1:500
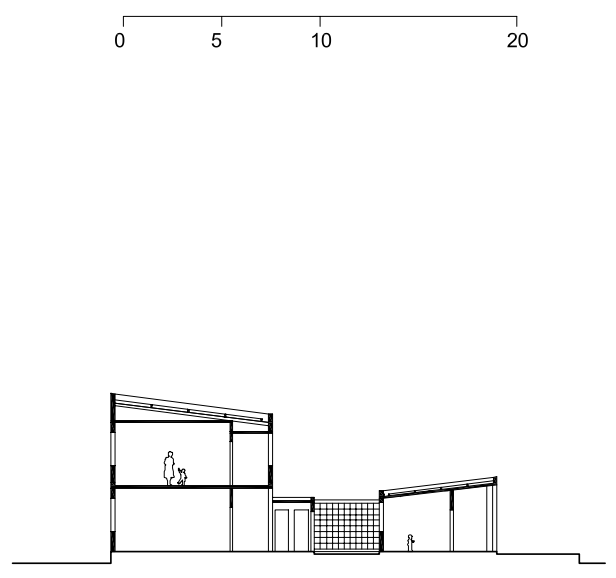

CORTE

1:500

\begin{tabular}{llll}
\hline & 5 & 10 & 20
\end{tabular} 


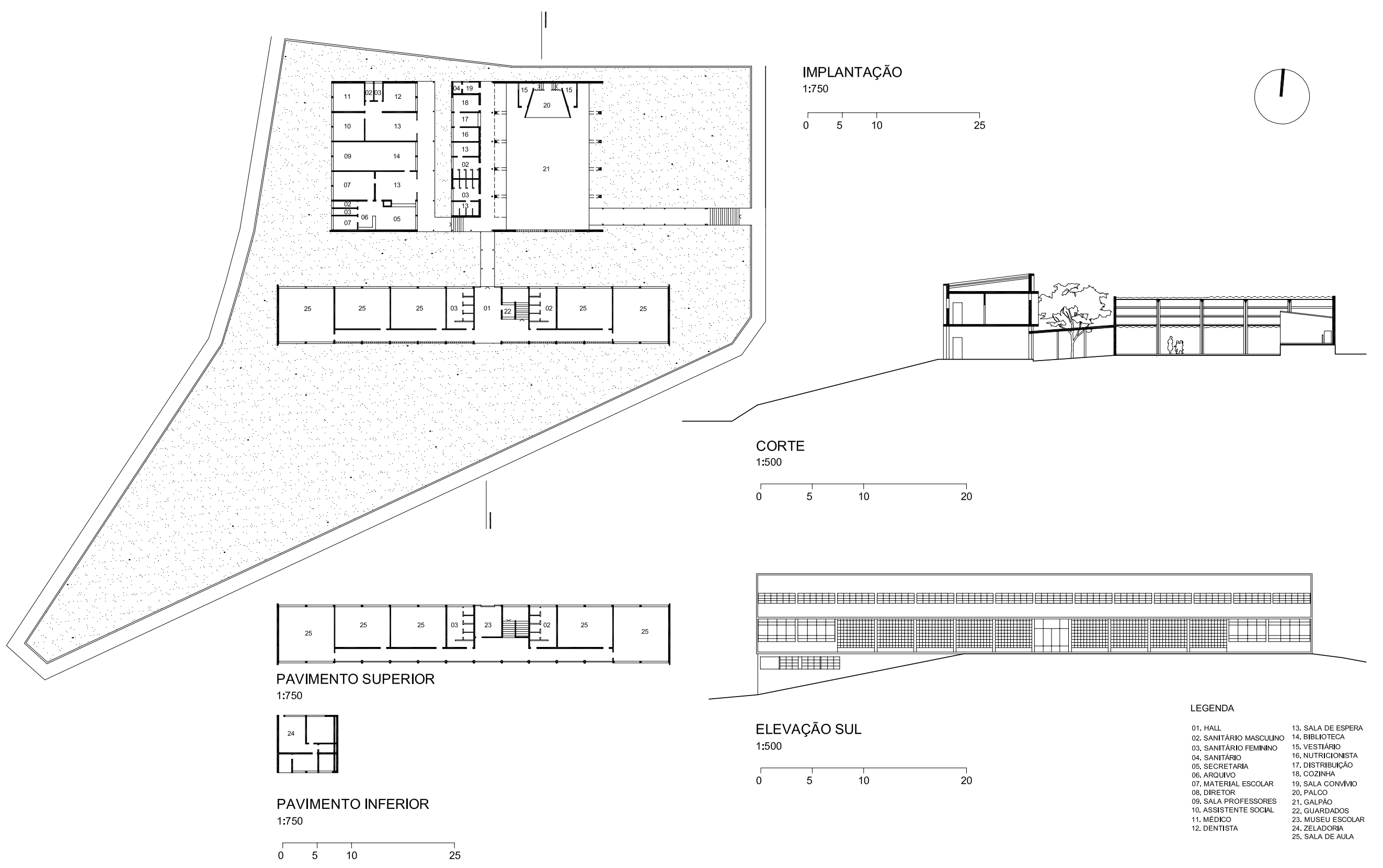




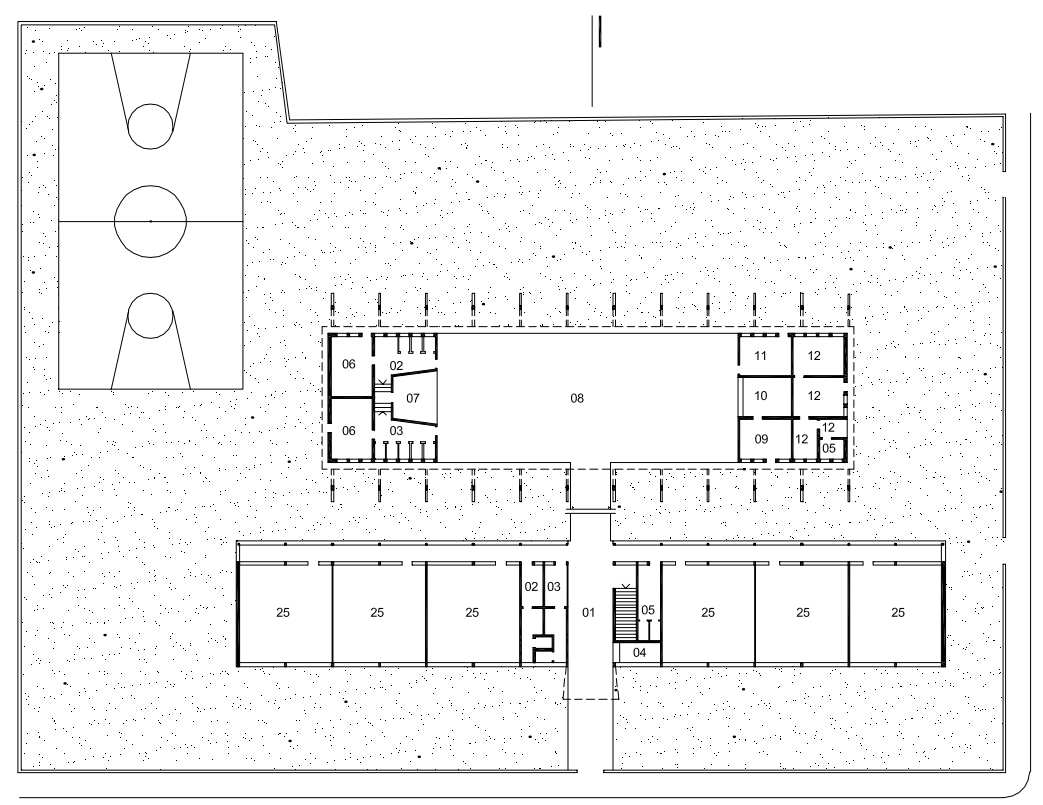

IMPLANTAÇÃO / TÉRREO

$1: 750$

$\begin{array}{lll}0 & 5 & 10\end{array}$

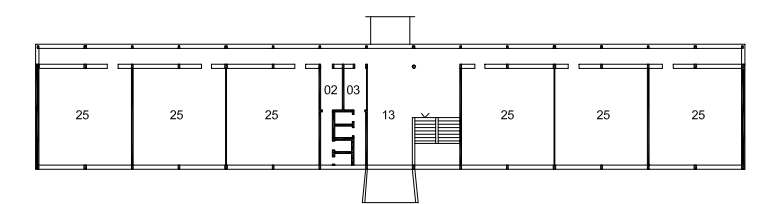

PRIMEIRO PAVIMENTO

$1: 750$
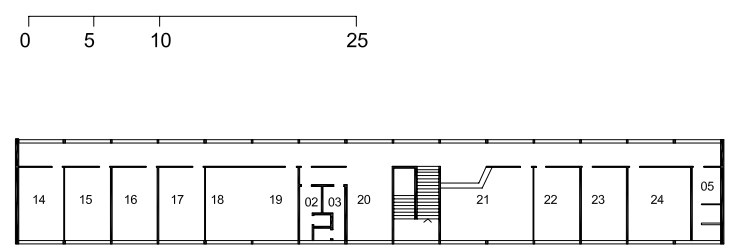

SEGUNDO PAVIMENTO

$1: 750$

\begin{tabular}{llll}
\hline & 5 & 10 & 25
\end{tabular}

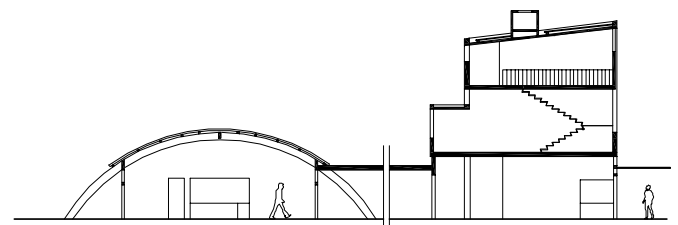

CORTE

$1: 500$

\begin{tabular}{llll}
\hline 0 & 5 & 10 & 20
\end{tabular}

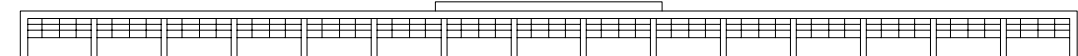

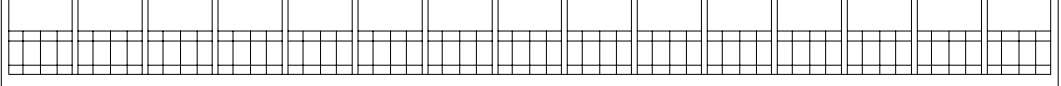

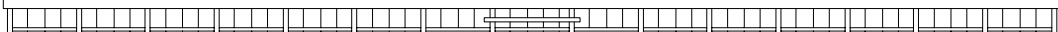
角

ELEVAÇÃO LESTE

$1: 500$

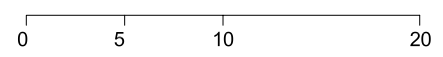

LEGENDA

$\begin{array}{lll} & \\ \text { 11. HALL DE ENTRADA } & \text { 14. DENTITTA } \\ \text { 02. SANITARIO MASCULLNO } & \text { 15. RADGGRAFA }\end{array}$

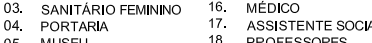

05. MUSEU

07. PALCO
08. GALPAOO

09. COZINHA

11. DEPOSIT
12. ZELDOORIA
13. MUSEU

22. MATERALL ESCOLAR

24. DREETORIA
25. SALA DE AULA 


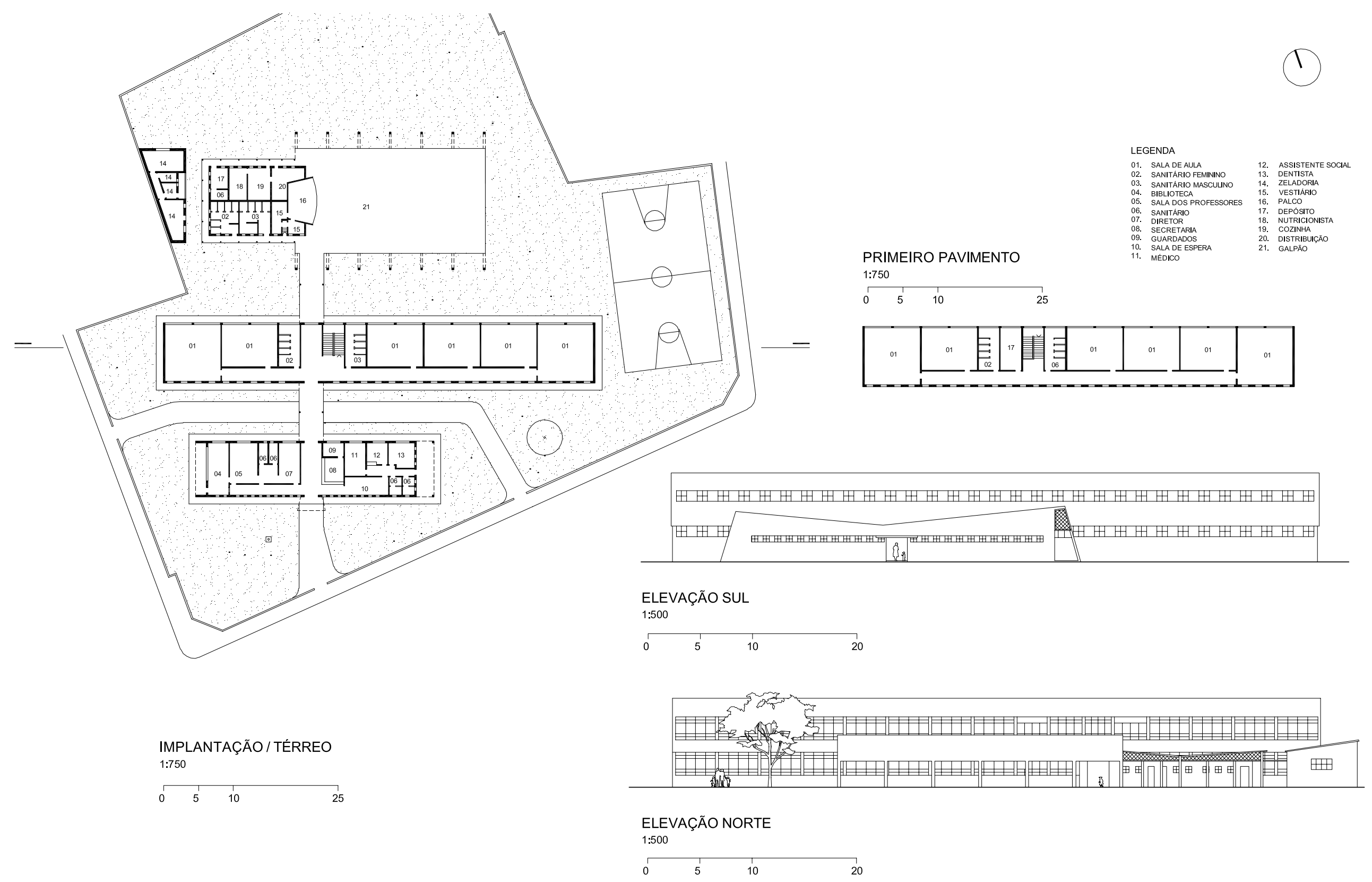




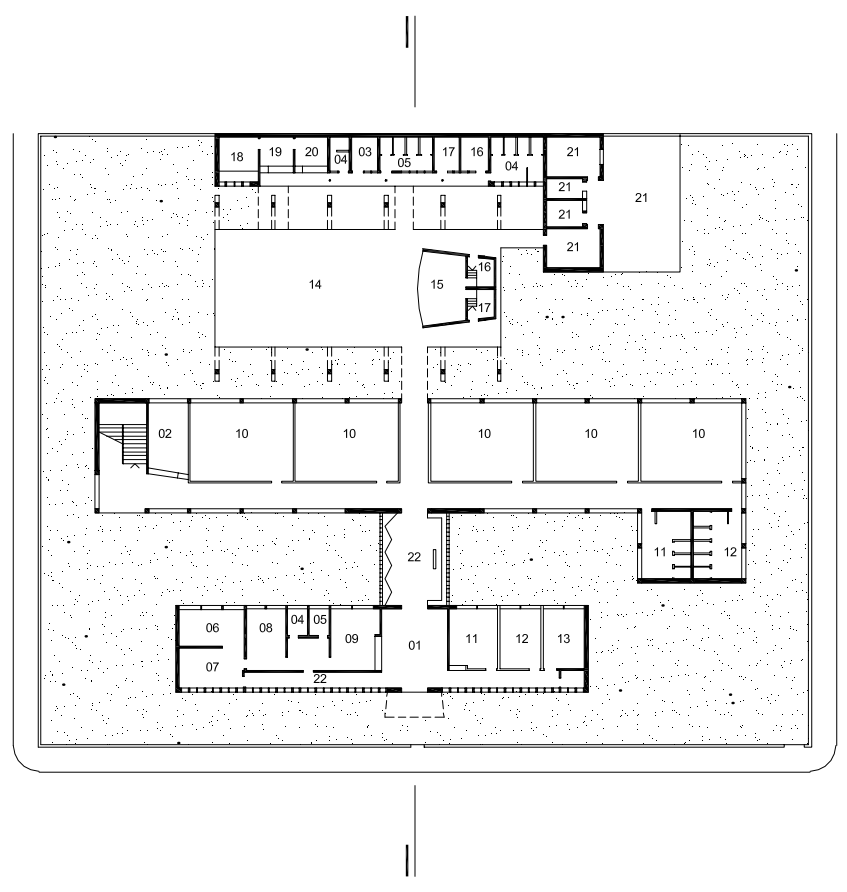

IMPLANTAÇÃO / TÉRREO 1:750

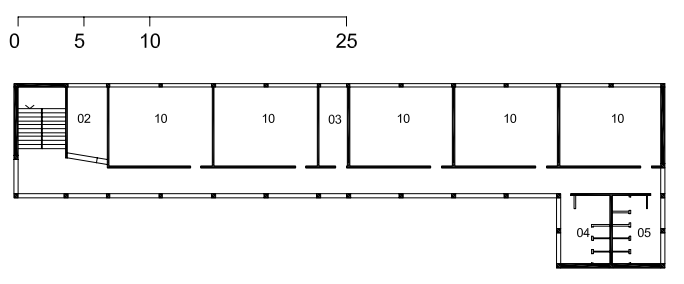

PRIMEIRO PAVIMENTO

1:750

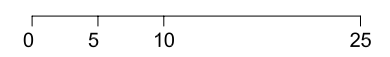

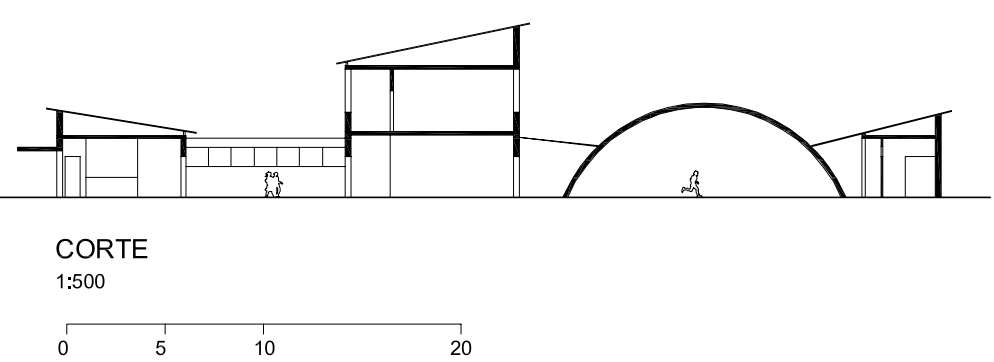

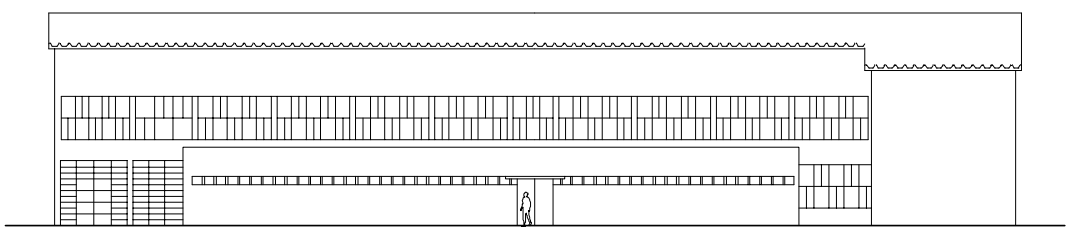

ELEVAÇÃO SUDOESTE

1:500

\begin{tabular}{llll}
\hline & 1 & 1 & 20
\end{tabular} 


\section{b) Blocos articulados com recreio em pilotis:}

Dos quinze projetos sem autoria definida, três projetos adotaram a implantação a partir da articulação de blocos funcionais (de ensino, de recreação e de administração), com o recreio abrigado em pilotis.

Fazem parte dessa classificação as escolas:

EE Aristides de Castro (195I) - bairro Jardim Paulista

Diretoria de Ensino - Região Leste 4 (1950) - bairro da Vila Matilde

EE Brasílio Machado (|95|) - bairro da Saúde 


\section{EE Aristides de Castro (1951)}

Localiza-se no bairro Jardim Paulista e por apresentar solução com iluminação bilateral em todas as salas de aula, e o setor administrativo no $1^{\circ}$ andar, essa escola, aproxima-se da produção do engenheiro Ernest Mange. $\bigcirc$ uso do pilotis foi conseqüência da necessidade de área que permitisse a existência de pátios entremeando todas as salas de aula. 

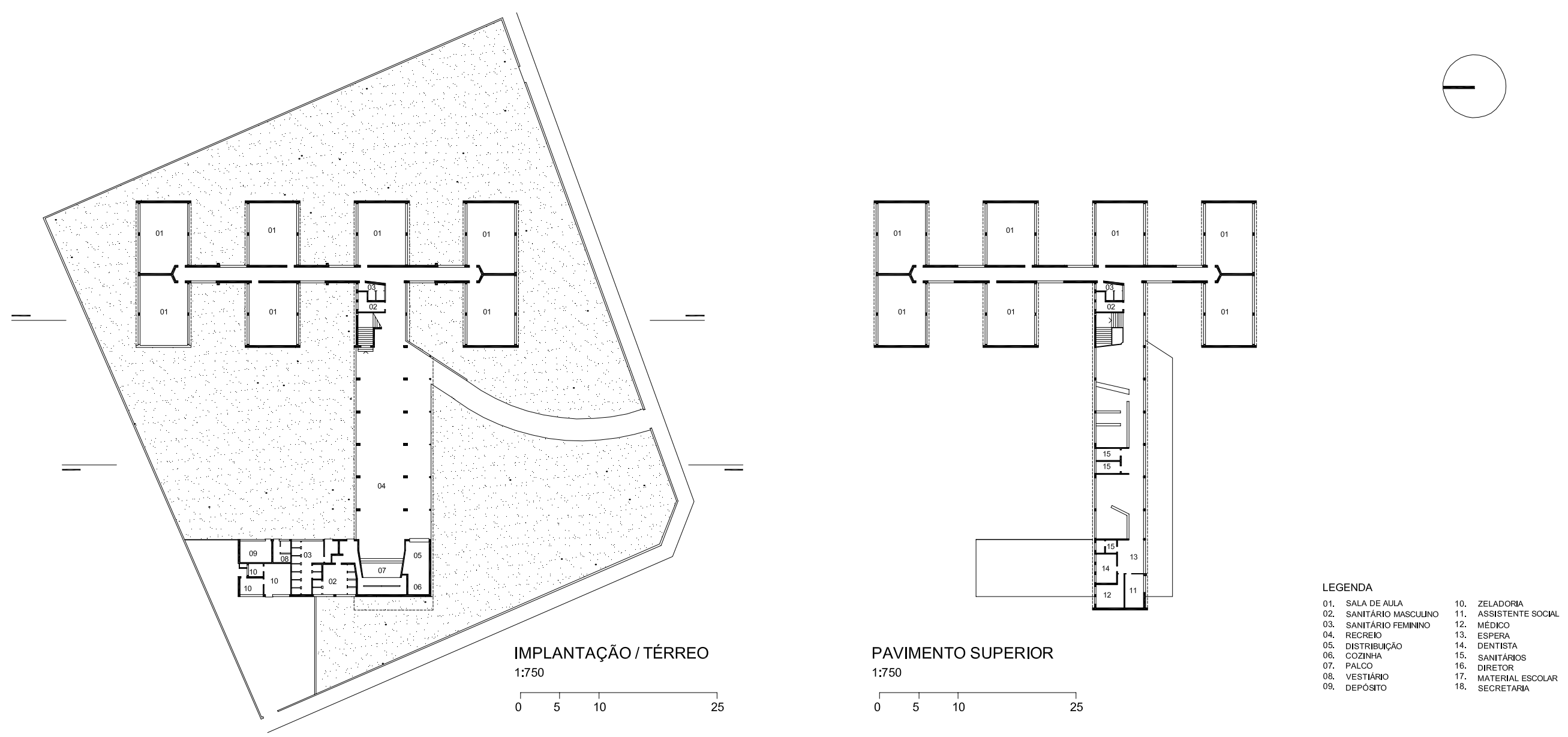

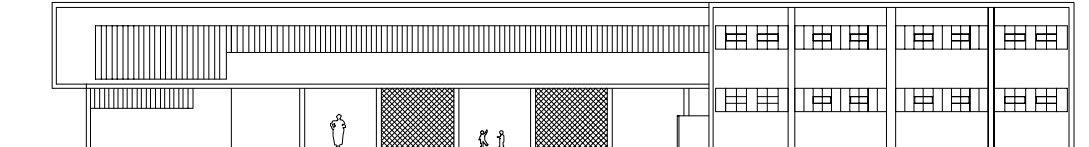

ELEVAÇÃO SUL

$1: 500$

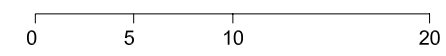

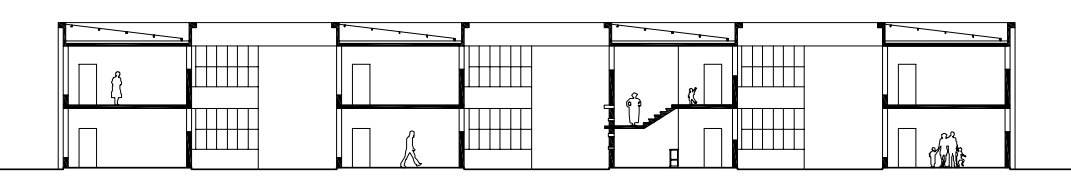

CORTE

1:500

\begin{tabular}{llll}
\hline & 5 & 10 & 20
\end{tabular}

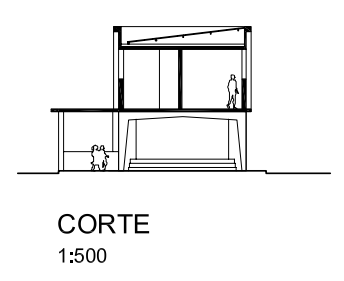

EE ARISTIDES DE CASTRO 277 


\section{Diretoria de Ensino - Região Leste 4 (1950)}

Localiza-se no bairro de Vila Matilde em terreno exíguo, que justifica o uso do pilotis para abrigar o recreio coberto. Sua volumetria final em asa de borboleta, característica de seu conjunto arquitetônico, remete às soluções do mesmo tipo de cobertura encontradas e projetadas pelo arquiteto Eduardo Corona. 


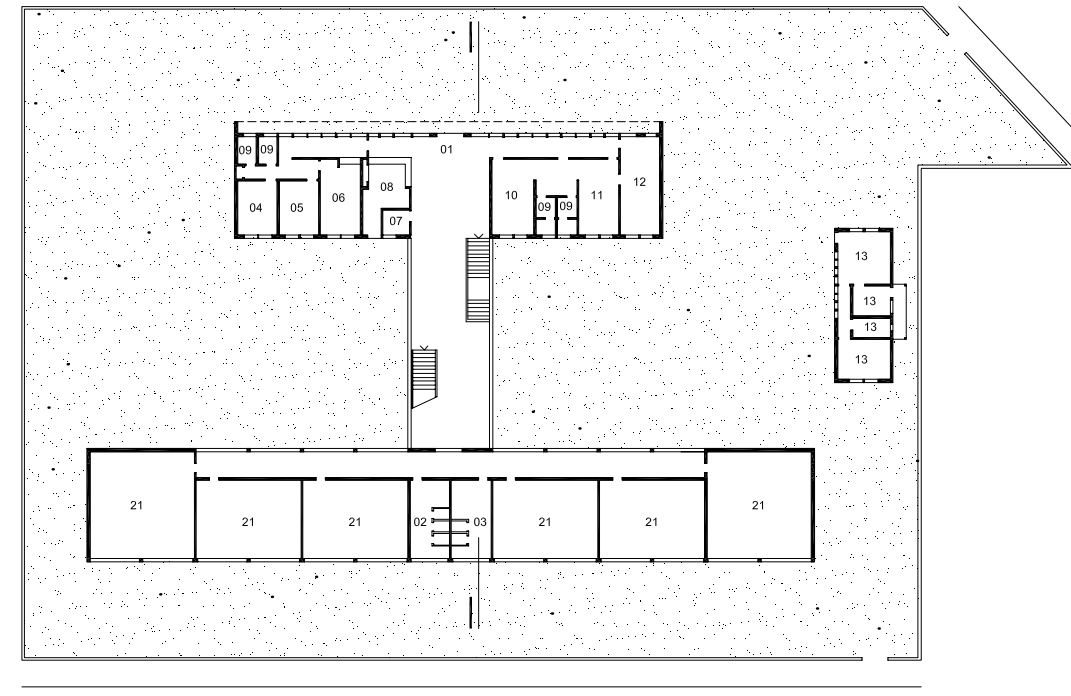

IMPLANTAÇÃO/ PRIMEIRO PAVIMENTO

1:750

\begin{tabular}{llll}
\hline & 1 & 10
\end{tabular}

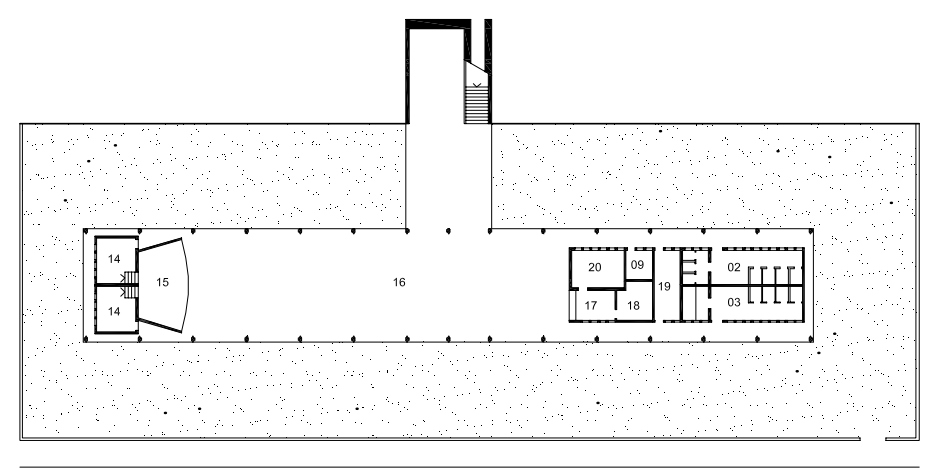

TÉRREO

1:750

\begin{tabular}{llll}
\hline & 1 & 10
\end{tabular}

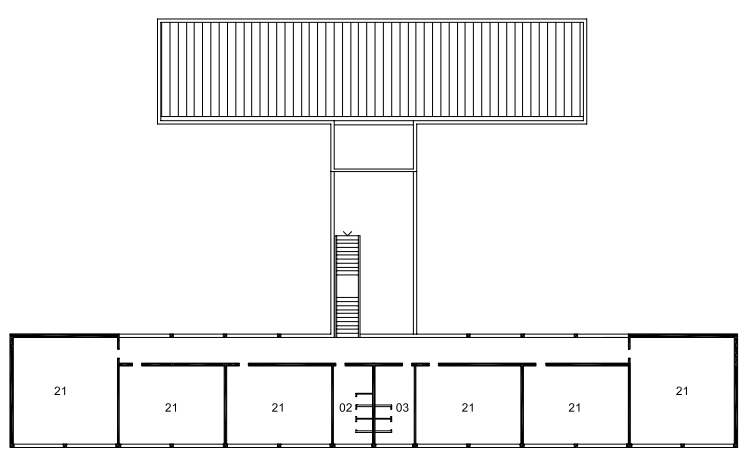

SEGUNDO PAVIMENTO 1:500

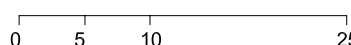

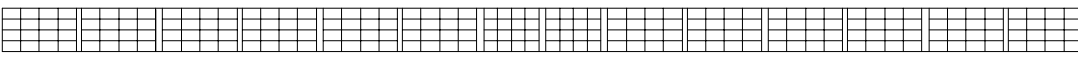

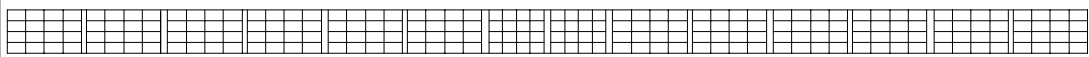

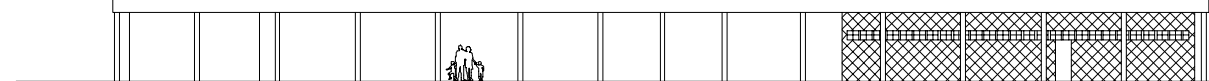

\section{ELEVAÇÃO NOROESTE}

$1: 500$
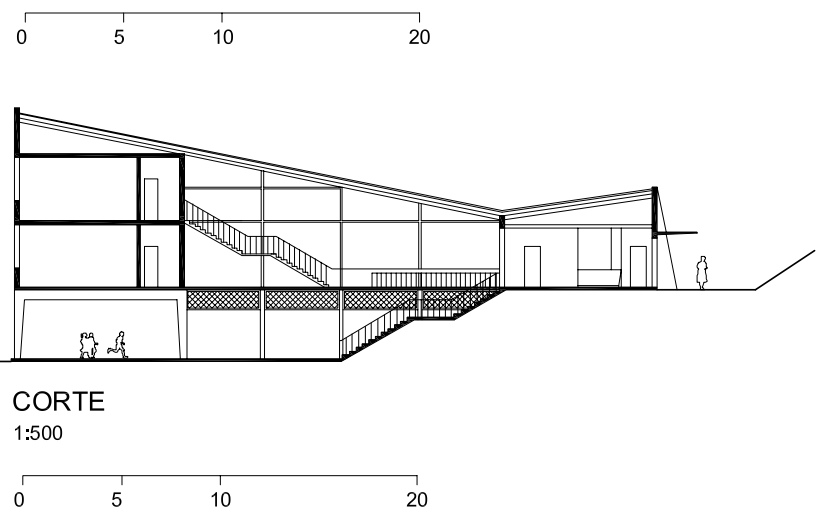

LEGENDA

01. HALL DE ENTRADA
02. SANTIARIO FEMININO 3. SANITARIO MASCULINO

ASSISTENTE SOCIM
SECRETARAA

MATERIAL ESCOUAR

SANTARRO
DRETORA
SALAODS

\begin{tabular}{llll}
\hline & 5 & 10
\end{tabular}

2. BBLLOTECA
13. ZELADORIA

IARIO

RECREIO COB
DISTRIBUICAOA

19. DEPÓSTIO
20. COZINA
21. SALADEAUIA

21. SALA DEAULA 


\section{EE Brasílo Machado (1951)}

Localiza-se no bairro da Saúde, essa escola tem o recreio caracterizado por área em pilotis sob o bloco de salas de aula. Isso se justifica por se tratar de escola com programa extenso, em atendimento às 16 salas de aula, salas ambientes para disciplinas específicas, laboratórios e anfiteatro com cabine de projeção.

A implantação é caracterizada por dois blocos paralelos, com 2 pavimentos cada, recuados de maneira a criar pátios internos a fim de garantir iluminação e insolação adequadas para todas as salas de aula. 


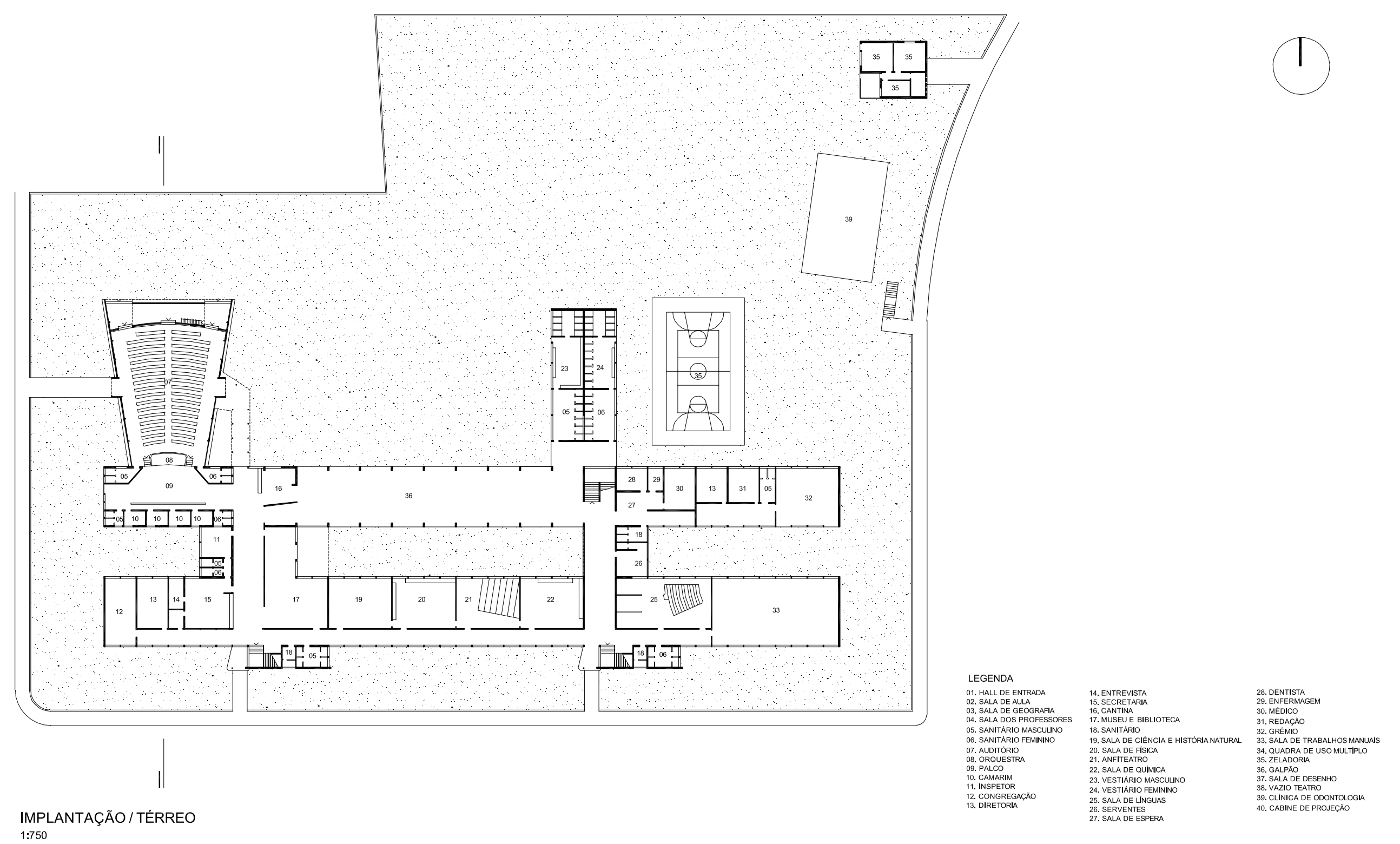




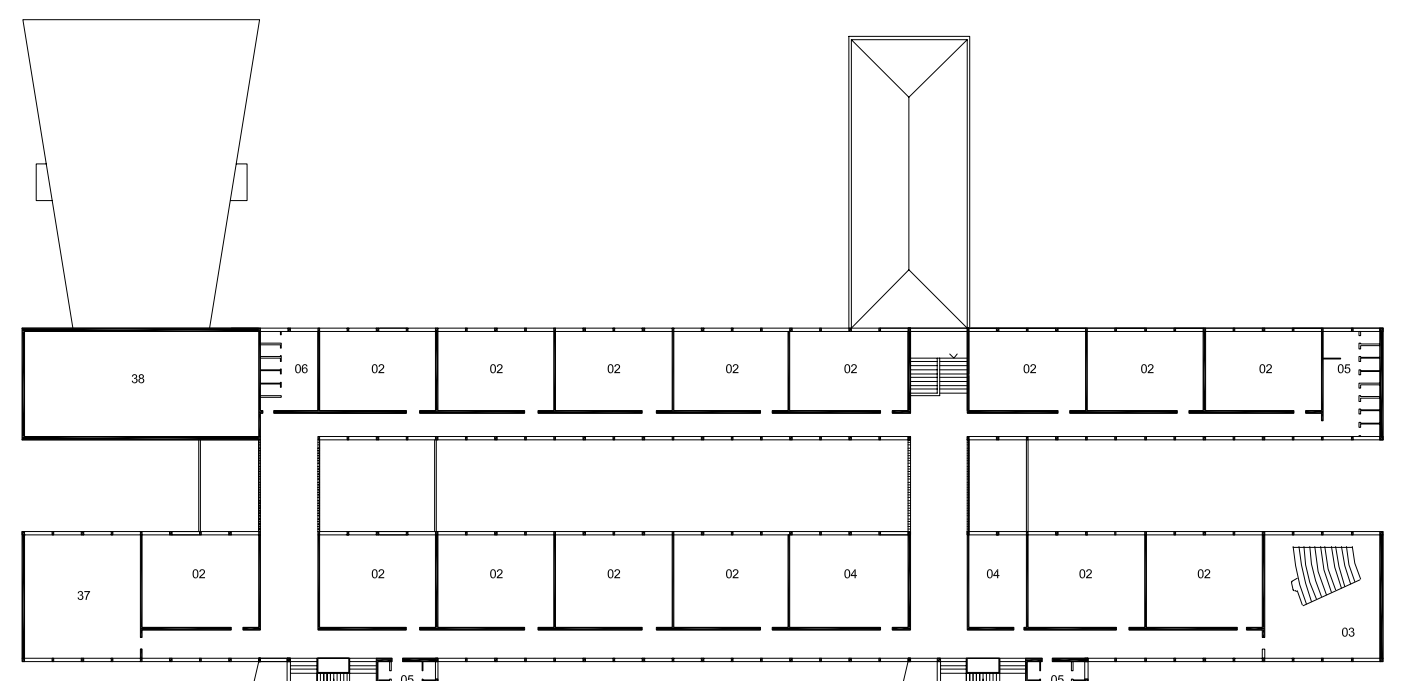

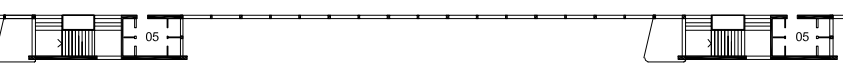

PAVIMENTO SUPERIOR

1:750

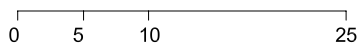

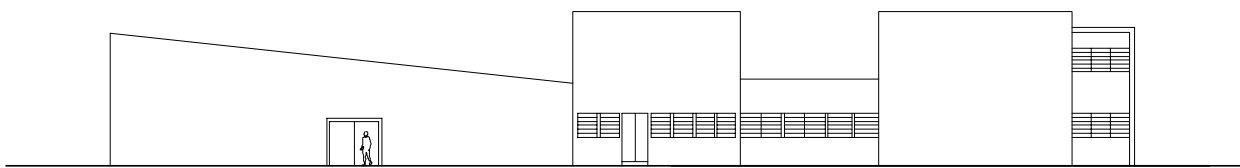

ELEVAÇÃO OESTE

1:500

\begin{tabular}{llll}
\hline & 5 & 10 & 20
\end{tabular}

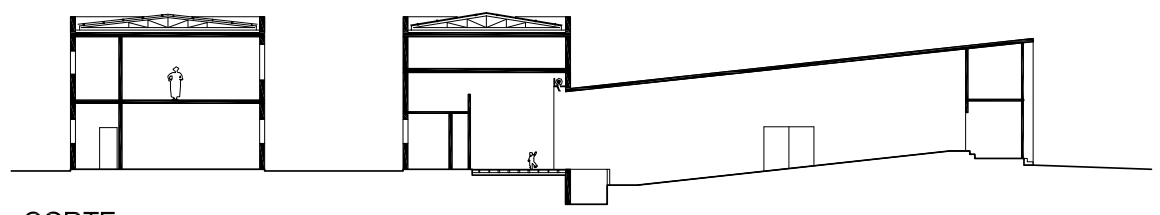

CORTE

1:500

\begin{tabular}{llll}
\hline & 1 & 10
\end{tabular} 


\section{c) Blocos articulados com recreio em plano inclinado:}

Dos quinze projetos sem autoria definida, três projetos adotaram a implantação a partir da articulação de dois blocos funcionais.

Fazem parte dessa classificação as escolas:

EE Deputado Pedro Costa (1952) - bairro da Vila Guilherme

EE República do Uruguay (1953) - bairro de Cangaíba

EE Dr. José Pereira de Queiroz (195I) - bairro da Vila Matilde 


\section{EE Deputado Pedro Costa (1952)}

Localizada no bairro de Vila Guilherme, essa escola caracteriza-se por seu reduzido programa arquitetônico: somente 5 salas de aula. A escola define sua implantação a partir de dois blocos térreos paralelos, que se conectam pela extensão da cobertura em asa de borboleta, que caracteriza a volumetria do conjunto arquitetônico conformado. 


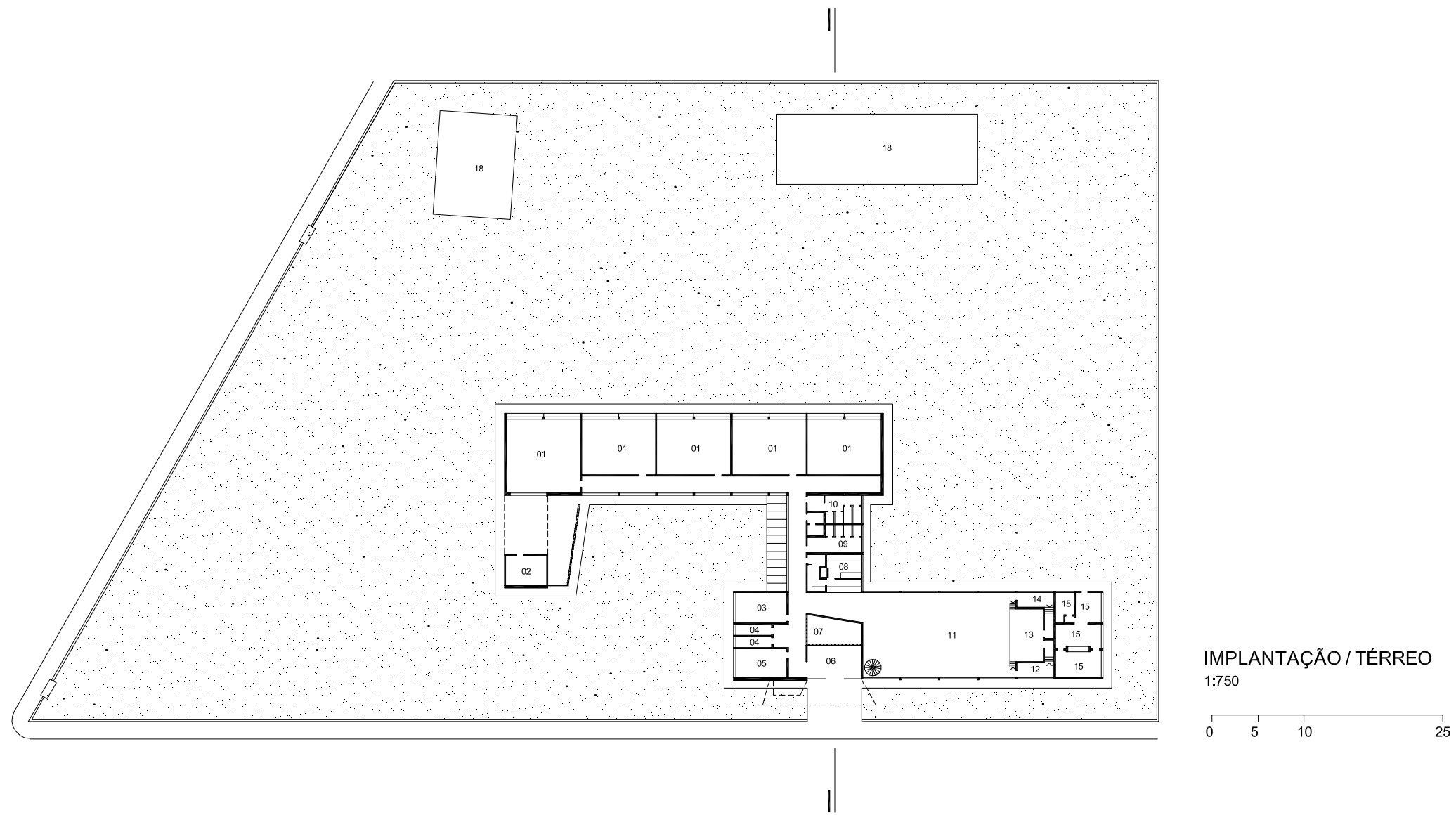

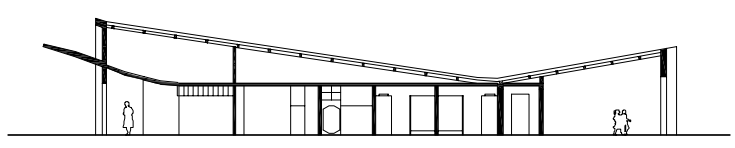

CORTE

1:500

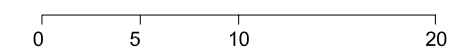

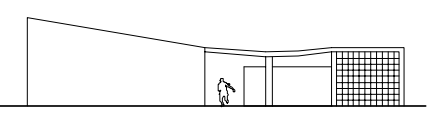

ELEVAÇÃO OESTE

1:500

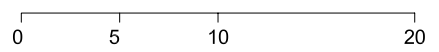

LEGENDA

01. SALA DE AULA
02. BIBLIOTECA

03. DIRETORIA
04. SANITARTO
05. DENTISTA

05. DENTISTA
06. SALA DOS PROFESSOPIE

07. DESPENA

08. COZINAA
09. SANITARIO MASCULINO

10. SANITARIO FEMININO

11. GALPÄO
12. CAMARIM
13. PALCO

14. DEFOSITO
15. ZELADORAA

15. ZELADORIA
16. ENSINO ESPECIAL

18. DORMITORIO SERVICOCD 


\section{EE República do Uruguai (1953)}

Localizada no bairro de Cangaiba, essa escola térrea também atende a um diminuto programa arquitetônico: 6 salas de aula. Sua volumetria define-se através de dois blocos paralelos com cobertura em planos inclinados e voltados para o pátio central; sua passagem coberta é resolvida através de uma pequena abóbada. 

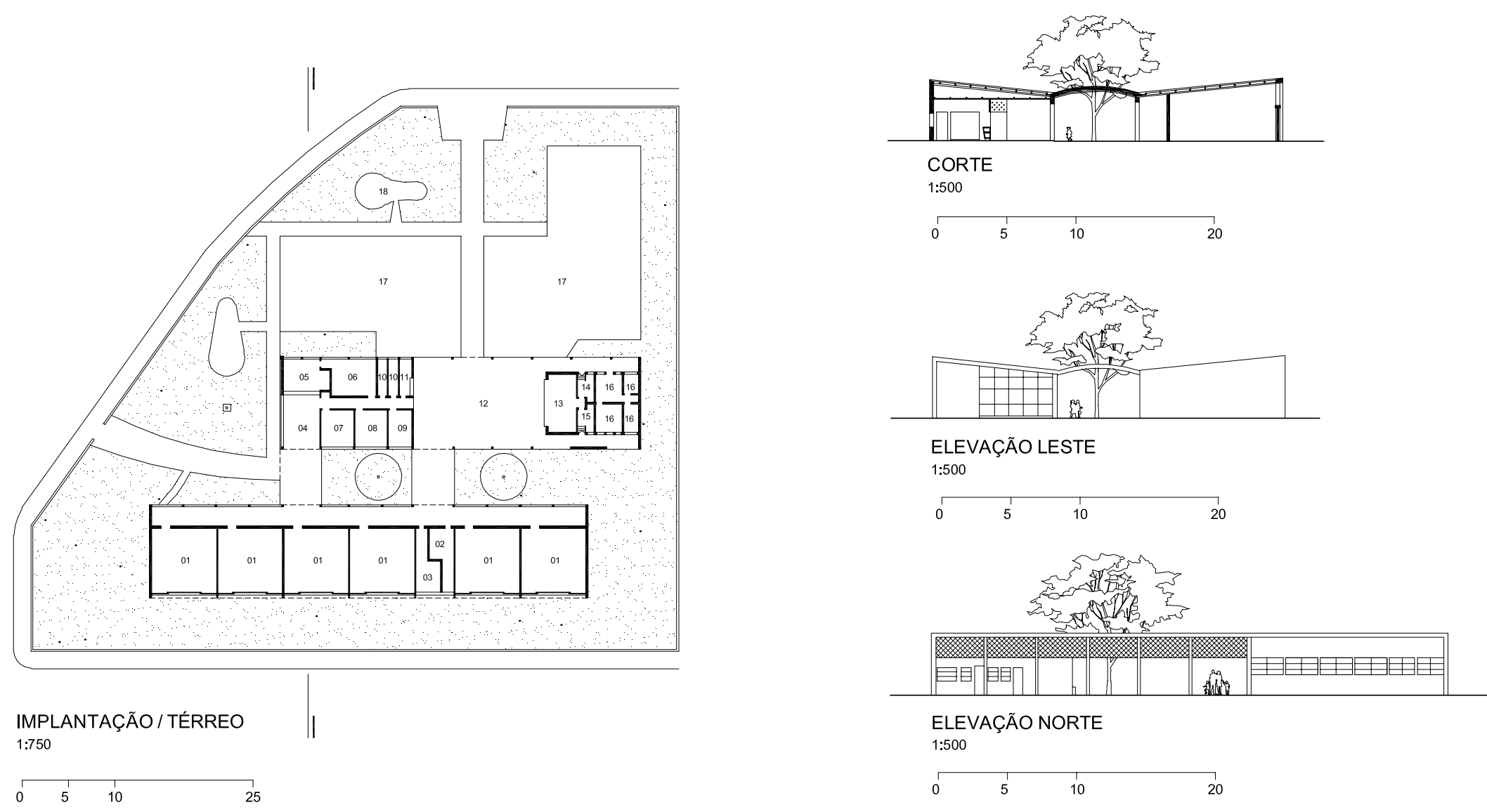

LEGENDA

01. SALA DE AULA
O2. SAITARIO MASCULINO 10. SANITARIO
11 COZINHAA 02. SANITARIO MASCULINO
03. SANITARIO FEMININO
04. HAII

05. SECRETÁRIA 


\section{EE Doutor José Pereira de Queiroz (1951)}

Localizada no bairro de Vila Matilde, essa escola caracteriza-se pela articulação de dois blocos funcionais: bloco de ensino com 8 salas de aula, distribuídas em 2 pavimentos, setor administrativo e setor recreativo abrigados em bloco térreo com cobertura em uma água. 


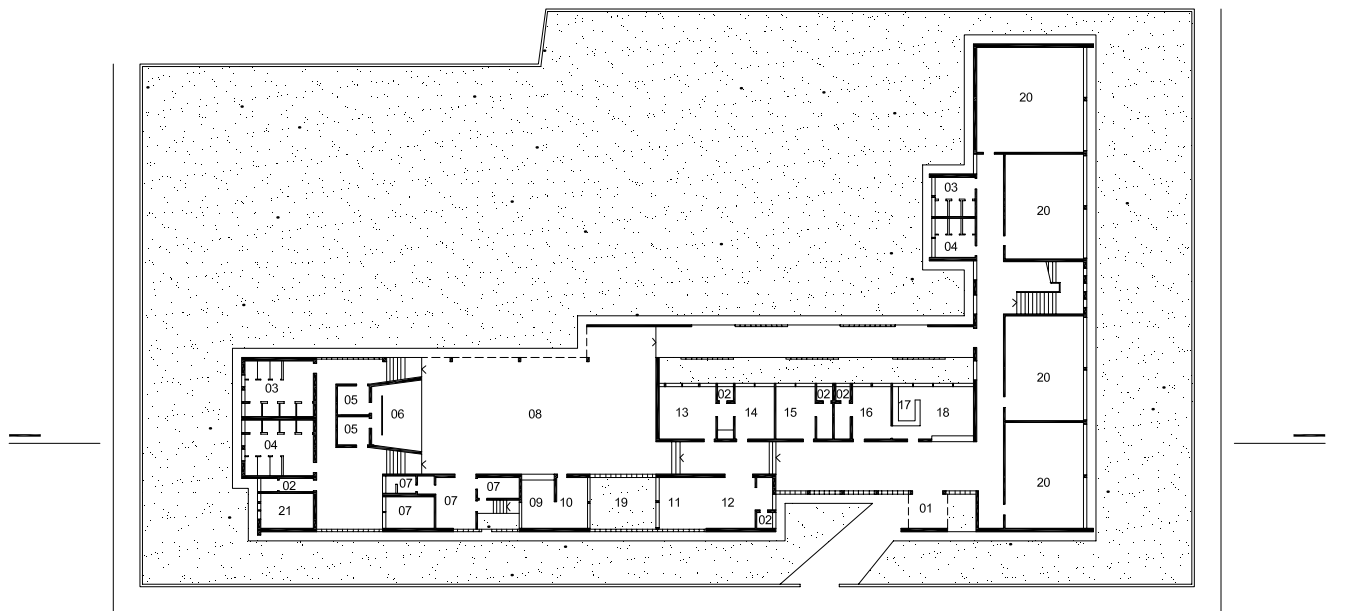

IMPLANTAÇÃO / TÉRREO

1:750
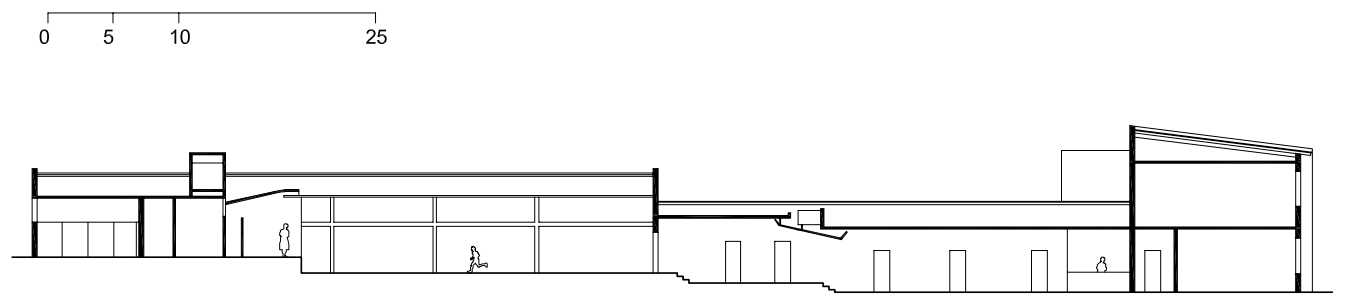

CORTE

1:500

\begin{tabular}{llll}
\hline & 5 & 10 & 20
\end{tabular}

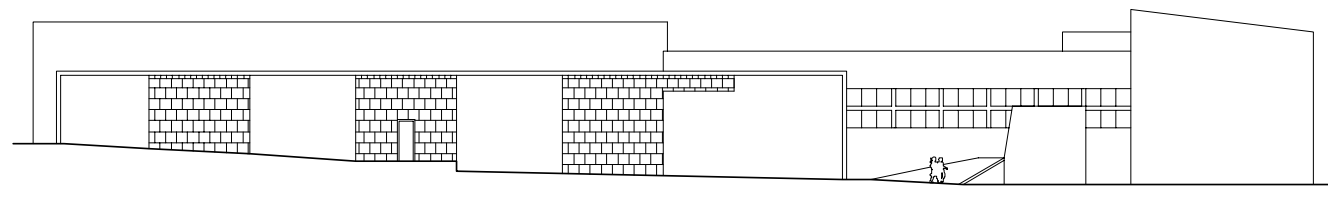

ELEVAÇÃO SUDESTE

\begin{tabular}{llll}
\hline & 5 & 10 & 20
\end{tabular}

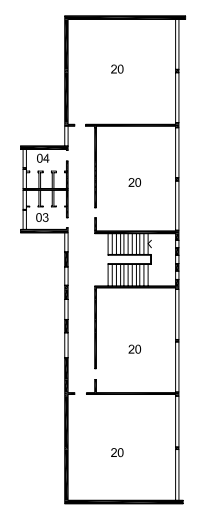

PRIMEIRO PAVIMENTO

1:750

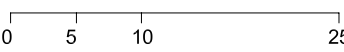

LEGENDA

01. HALL DE ENTRRAA
02. SANITARIO

03. SANATRRIO MASCULINO

6. PESTIARIO

08. RECREIO

08. RECREIO
09. DISRRBIIC
10. COZINHA
13. BiBLIOTECA
12. SALA DOS PROFESSORES

DENTISTA

15. ASSISTENTE SOCIAL
DIRETOR

17. AREUIVO
18. SECPETAPIA
19.

19. JARDIM
20. SALA DE AULA
21. DEPOSITO 


\section{d) Bloco único com recreio no pilotis:}

Dos quinze projetos sem autoria definida, somente um projeto adotou a solução de concentrar todo o programa arquitetônico em um mesmo volume. 


\section{EE Toledo Barbosa (1949)}

Localizada no bairro de Vila Guilherme, trata-se de uma das primeiras escolas edificadas pelo $2^{\circ}$ Convênio Escolar. $\bigcirc$ partido adotado, concentrando todo o programa em um mesmo bloco, é conseqüência das dificuldades topográficas existentes.

volume final resultou em edifício com 3 pavimentos: térreo com o pilotis, ocupado pelo recreio coberto ao lado do setor administrativo e $1^{\circ}$ e $2^{\circ}$ andares, ocupados pelas 14 salas de aula. 


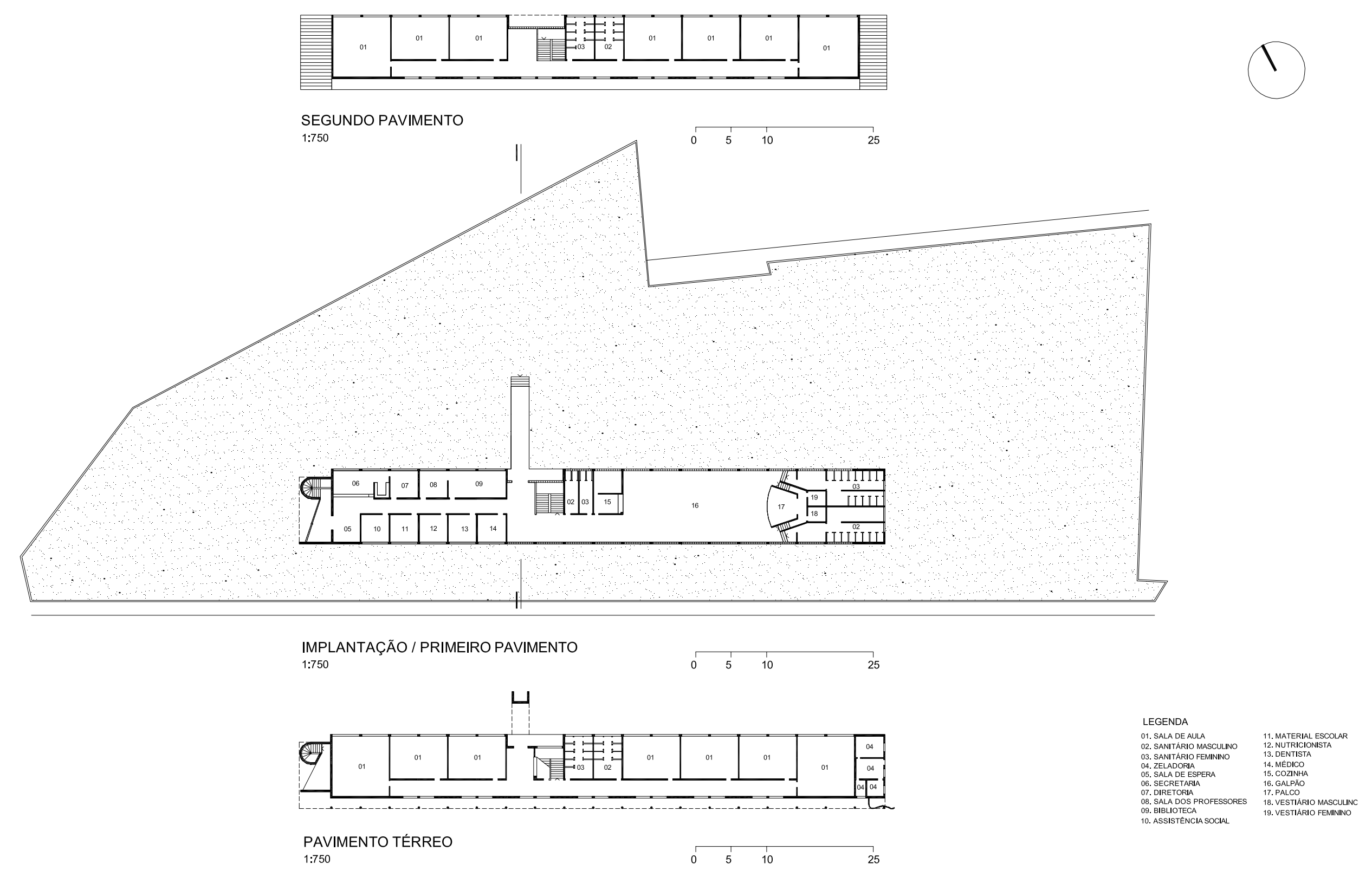



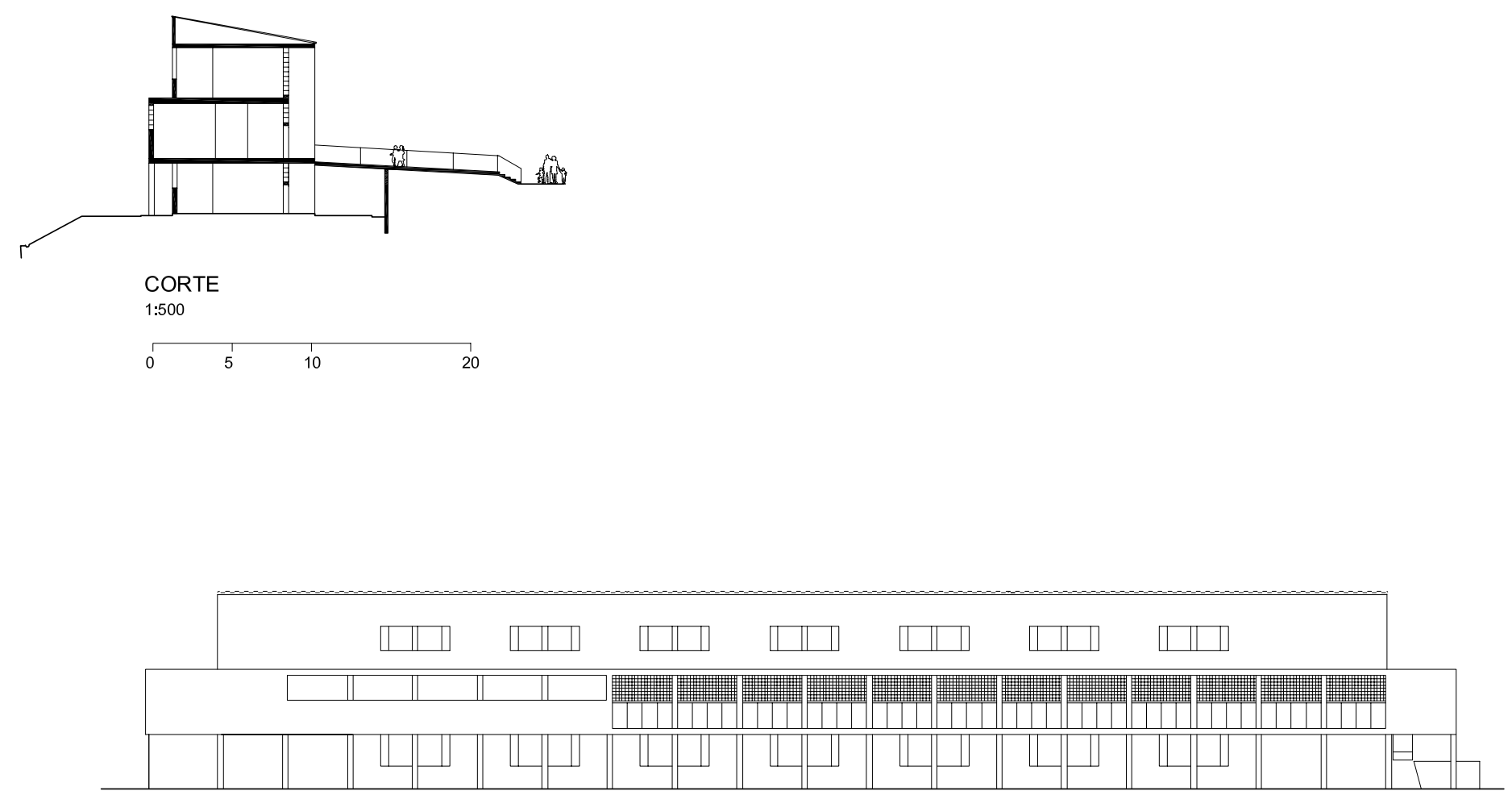

ELEVAÇÃO SUDESTE

1:500

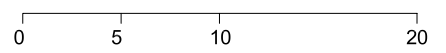


e) Bloco articulados com recreio em pé-direito duplo:

Dos quinze projetos sem autoria definida somente um projeto adotou a solução de recreio coberto em pé-direito duplo. 


\section{EE Manuela Lacerda Vergueiro (1952)}

Essa escola, localizada no bairro do Ipiranga, caracteriza-se pela articulação de três blocos funcionais: de ensino, em 2 pavimentos com salas nos 2 andares; de administração em um único pavimento e de recreação com pé-direito duplo, possibilitando a exibição de filmes. 


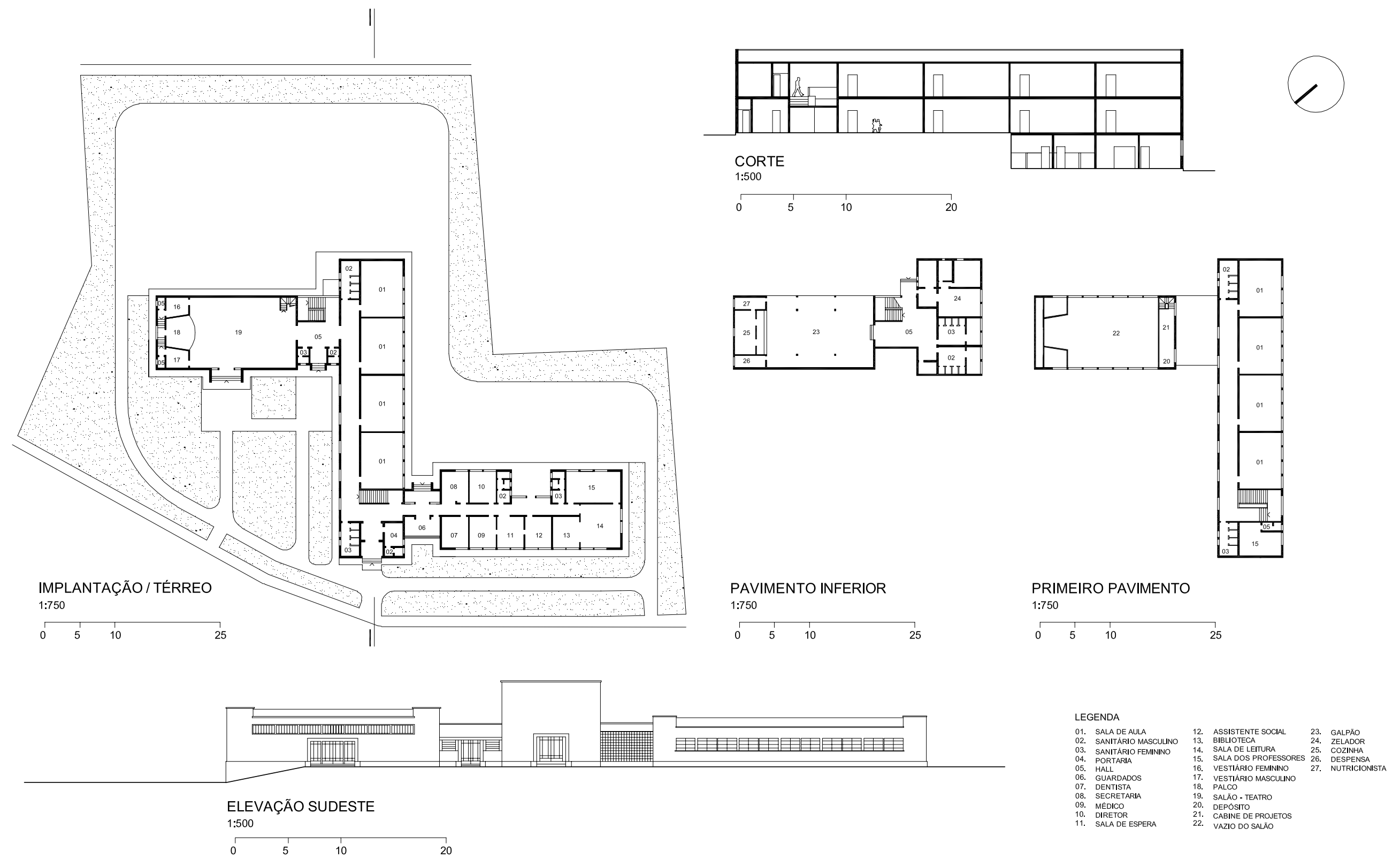


CONSIDERAÇÕES FINAIS 
Produzir com velocidade uma arquitetura de qualidade, comprometida com os ideais do escolanovismo na reconstrução da escola pública, trouxe mais do que um harmonioso e moderno resultado formal dos edifícios, foi o verdadeiro sentido da produção das 52 escolas do $2^{\circ}$ Convênio Escolar.

A consciência da questão estratégica da educação pública, na coordenação dos projetos, implementada por Hélio Duarte, ao lado de uma equipe afinada com os mesmos ideais de fazer arquitetura a partir de sua função social, conferiu unidade conceitual à vasta produção do $2^{\circ}$ Convênio Escolar.

A forma e a coerência resultantes registraram esse comprometimento com o ensino e a nova pedagogia, e o apoio incondicional do engenheiro José Amadei, presidente do $2^{\circ}$ Convênio Escolar, foi estratégico para a efetivação de resultado tão significativo para a arquitetura paulista, haja vista a interferência política imediatista, que planos como esses suscitam em função da visibilidade pública de seu resultado.

Hélio Duarte temia, entretanto, que seu esforço na busca pela qualidade arquitetônica fosse transformado em forma sem conteúdo, uma vez que perderia sentido, se desprovido da pedagogia transformadora preconizada pelo escolanovismo de Anísio Teixeira. Portanto, dependia das prioridades políticas e do efetivo preparo dos professores na construção desses espaços. Nesse sentido, seu trabalho, ao longo da história, foi frustrado, pois a questão quantitativa superou as questões qualitativas na educação. Anísio Teixeira apontou as conseqüências dessa política, conforme pudemos ver.

As escolas, no recente plano da Secretaria da Educação do Estado de São Paulo, de transformar parte delas em escolas de ensino integral, apontam para a possibilidade de recuperar esses princípios e usar espaços dos edifícios do convênio escolar, de acordo com o potencial de uso projetado. 
A Comissão Executiva do $2^{\circ}$ Convênio Escolar, segundo depoimentos dos arquitetos participantes, manteve qualidade e coerência na sua produção, mas o mesmo não se pode afirmar sobre a qualidade das obras, uma vez que a Subcomissão de Obras executava os edifícios sem contar com a efetiva participação dos arquitetos no processo de construção. $\bigcirc$ arquiteto Eduardo Corona chegou a questionar a qualidade das obras que poderia comprometer o resultado final do conjunto das escolas, alegando, inclusive, esse motivo para a sua demissão do Convênio, em 1952.

conjunto das 52 escolas construídas pelo $2^{\circ}$ Convênio Escolar revela, para nossa atualidade, o entusiasmo e a idéia força que movia a arquitetura da década de 50 de desenvolvimento nacional com justiça social, uma idéia que não considerava a arquitetura enquanto fim, mas que fazia dela o meio de conquistar um futuro melhor: a verdadeira arquitetura moderna.

Era essa idéia força que traçava as prioridades para as escolhas pertinentes ao processo projetual e, nesse caso, a idéia força era o atendimento pleno às crianças, em uma cidade que não parava de crescer, ou seja, produzir um grande volume de edifícios em um curto prazo, e qualquer projeto, como podemos comparar com a situação existente, sempre é penalizado nesses cronogramas, em detrimento dos longos prazos políticos, quanto às decisões ligadas às questões da educação pública.

Enquanto somente invólucros, desprovidas de conteúdo, as escolas pouco nos diriam 50 anos depois, além do seu significativo comprometimento com a arquitetura moderna nacional. $\bigcirc$ que descobrimos, através desse conjunto de edifícios é a maneira pela qual a produção destas escolas se organizou calcada no ideal de escola pública republicana que ao construir a escola para todos precisou construir os melhores edifícios escolares e precisou considerá-lo como parte estratégica de uma cidade democrática e educadora 
A idéia força que alimentou nossa modernidade na produção de edifícios escolares, nesse período, fundamenta-se na necessária e constante renovação de nossa sociedade, na busca democrática, a partir da educação, de um país com igualdade de oportunidades para todos e todas as crianças. Este testemunho faz-se fundamental para repensarmos o início deste novo século e o estado em que se encontra a educação em nosso país.

A idéia força na educação nacional continua seu movimento, e a pergunta que se coloca é de que forma nós, arquitetos, poderemos responder e nos inserir nesse processo?

A equipe municipal da EDIF com o trabalho dos arquitetos Alexandre Delijaicov, Wanderlei Ariza e André Takiya nos deu uma resposta com os projetos CEUs, e a FDE, através da coordenação das arquitetas Avany de Francisco Ferreira e Mirela Geiger de Mello, com o plano de escolas em pré-moldado também o fizeram.

Esta dissertação com o registro do $2^{\circ}$ Convênio Escolar, pretende, contribuir e manter viva a possibilidade de um trabalho estratégico e digno para nós, arquitetos ao lado dos pedagogos e educadores, na área da educação pública, com aquilo que é a nossa parte: projetos de arquitetura inseridos adequadamente nas cidades e fundamentados em projetos pedagógicos transformadores da situação em que hoje nos encontramos.

"Wells, em uma de suas profecias a respeito do nosso mundo, imaginava-o renascendo de uma fase de destruição total, por intermédio de um pequeno grupo de aviadores, que recolhe a herança da atitude científica ao espírito de confiança na ação humana. Quem sabe se, entre nós, a missão não caberá aos arquitetos? Primeiro o seu trabalho toca em todos os setores da atividade humana. Nada do que é humano Ihes é estranho. Segundo o hábito de projetar para todos fá-los sensíveis e objetivos, inteligentes e desapaixonados. Em nenhuma outra arte, além desta, o casamento entre a ciência e a beleza é mais íntimo e inevitável. (..)" (Anísio Teixeira em "Um presságio de progresso", revista HABITAT ñ. 4, São Paulo, set-dez de 1951) 
ANEXO 


\section{CRÉDITOS DAS ILUSTRAÇ̃̃̃ES}

\section{CAPÍTULO I}

Páginas 19, 43, 47, 49, 50, 51, 52: FERREIRA, Avany de Francisco, CORRÊA, Maria Elizabeth Peirão e MELLO, Mirela Geiger de. 1998. Arquitetura Escolar Paulista: Restauro. São Paulo, Fundação para o Desenvolvimento da Educação.

Páginas 32, 34, 35, 36: OLIVEIRA, Beatriz Santos de. 1991. A modernidade oficial: A arquitetura das escolas públicas do distrito federal (1928-1940). Dissertação de mestrado, Faculdade de Arquitetura e Urbanismo da Universidade de São Paulo.

Páginas 55, 56, 57, 58, 59: NIEMEYER, Carlos Augusto da Costa. 2002. Parques infantis de São Paulo: lazer como expressão de cidadania. São Paulo, Anablume/ FAPESP.

\section{CAPÍTULO 2}

Páginas 85, III, 122: CAVALCANTI, Lauro. 200 I. Quando o Brasil era Moderno: Guia de Arquitetura 1928 - 1960. Rio de Janeiro, Editora Aeroplano.

Página 87: SOMEKH, Nádia, CAMPOS,Candido Malta. 2002. A cidade que não pode parar: planos urbanísticos de São Paulo no sáculo XX. São Paulo, Mackpesquisa. 
Páginas 92, 93, 94 (inferior), 95 (inferior): ANELLI, Renato.200 I. "Rino Levi: arquitetura e cidade". São Paulo, Romano Guerra.

Páginas 109 (inferior), II0 (superior), II 2 (inferior), II 3 (duas inferiores), 124, 125, 126: BRUAND, Yves. 1981. Arquitetura Contemporânea no Brasil. São Paulo, Perspectiva.

Páginas 108, II4, I19, I23: BONDUKI, Nabil. 2000. Affonso Eduardo Reidy. São Paulo, Editorial Blau.

Páginas 94, II 2 (superior): KAMITA, João Massao. 2003. Vilanova Artigas. São Paulo,: Cosak \& Naify.

Páginas 95 (superior), 107, II0 (superior), II3 (superior): Segawa, Hugo. 1999. Arquiteturas no Brasil: 1900 - 1990. São Paulo, Edusp.

\section{CAPÍTULO 3}

Páginas 138, 142, I43: DUARTE, Hélio. 197I. Escola Parque - Escola Classe. São Paulo, FAUUSP.

Páginas 133, 150, 169, 182, 190, 192, 195, 197, 199, 202, 203, 213, 231, 24I, 243: FERREIRA, Avany de Francisco, MELLO, Mirela Geiger de. 2006. Arquitetura Escolar Paulista: anos 1950 e 1960. São Paulo: Fundação para o Desenvolvimento da Educação. 
Páginas 15I, 167, 168: FERREIRA, Avany de Francisco, CORRÊA, Maria Elizabeth Peirão e MELLO, Mirela Geiger de. 1998. Arquitetura Escolar Paulista: Restauro. São Paulo, Fundação para o Desenvolvimento da Educação.

Página I34: KAMITA, João Massao. 2003. Vilanova Artigas. São Paulo,: Cosak \& Naify.

Página 160: AMADEl, José. 1951. "O Que é Convênio Escolar". Habitat, São Paulo, (4): 3,setembro/dezembro.

Páginas 174, 175, 235: MANGE, Ernest Robert de Carvalho. 1955. "Arquitetura Escolar". Acrópole. São Paulo (197), 2 I I-213, março.

Página 147: MASCARO, Carlos Corrêa. 1960. O Município de São Paulo e o Ensino Primário (ensaio de Administração Escolar). Livre-Docência, Faculdade de Filosofia Ciências e Letras da Universidade de São Paulo.

Página 173: Segawa, Hugo. 1990. "Hélio Duarte (1906 - 1989): moderno e peregrino". Projeto, São Paulo, (|3|), 5I, maio.

Páginas 217, 260: Ivanir Reis Neves Abreu.

Desenhos de todos os projetos do Convênio Escolar; FERREIRA, Avany de Francisco, MELLO, Mirela Geiger de. 2006. Arquitetura Escolar Paulista: anos 1950 e 1960. São Paulo: Fundação para o Desenvolvimento da Educação. 


\section{BIBLIOGRAFIA}

AMADEI, José. 1951. "O Que é Convênio Escolar". Habitat, São Paulo, (4): 3,setembro/dezembro.

. 1959. "Os problemas da escola" (Conferência pronunciada pelo engenheiro José Amadei, presidente do Convênio Escolar, no auditório da Biblioteca Municipal, em outubro de 1949). Engenharia Municipal, São Paulo(4): 7-9

ARTIGAS, João batista Vilanova. 1986. Caminhos da Arquitetura. São Paulo. Pini/ Fundação Vilanova Artigas.

. 1970. “Sobre Escolas...”. Acrópole, São Paulo, (377): I0- I3, setembro.

ANELLI, Renato.200 I. "Rino Levi: arquitetura e cidade". São Paulo, Romano Guerra.

BARONE, Ana Claudia Castilho. 2002. Team 10: arquitetura como crítica. São Paulo,FAPESP / Annablume.

BERMAN, Marshall. 1995. Tudo que é sólido desmancha no ar. São Paulo, Cia. das Letras.

BO, Lina. I95 I. "Primeiro: Escolas", Habitat, São Paulo, (4), I,setembro/dezembro. 
BONDUKI, Nabil. 1998. Origens da Habitação Social no Brasil. São Paulo, Estação Liberdade/FAPESP.

BONDUKI, Nabil. 2000. Affonso Eduardo Reidy. São Paulo, Editorial Blau.

BRUAND, Yves. 1981. Arquitetura Contemporânea no Brasil. São Paulo, Perspectiva.

BUFFA, Ester e PINTO, Gelson de Almeida. 2002. Arquitetura e Educação: Organização do Espaço e Propostas Pedagógigas dos Grupos Escolares Paulistas, 1893/197I. São Carlos, Edufscar.

CALDEIRA, Mário Henrique de Castro. 2006. Arquitetura para educação: escolas públicas na cidade de São Paulo (1934-1962). Tese de Doutoramento, Faculdade de Arquitetura e Urbanismo da Universidade de São Paulo.

CAVALCANTI, Lauro. 200I. Quando o Brasil era Moderno: Guia de Arquitetura 1928 1960. Rio de Janeiro, Editora Aeroplano.

COMISSÃO do Convênio Escolar. 1951. "As arquiteturas do Convênio Escolar". Habitat, São Paulo (4): 7-40, set.dez.

DEWEY, Jonh. 1967. Vida e educação. São Paulo, Ed. Melhoramentos. 
DUARTE, Hélio de Queiroz. 1965. "Considerações em torno do problema escolar". Acrópole.São Paulo (3|4): 34-35, fevereiro.

1956. "Considerações sobre a arquitetura e educação". Acrópole". São

Paulo(210):236-38, abril.

1971. Escola Parque - Escola Classe. São Paulo, FAUUSP.

FAUSTO, Boris. 1989. A Revolução de 1930. São Paulo, Editora Brasiliense.

FERREIRA, Avany de Francisco, CORRÊA, Maria Elizabeth Peirão e MELLO, Mirela Geiger de. 1998. Arquitetura Escolar Paulista: Restauro. São Paulo, Fundação para o Desenvolvimento da Educação.

FERREIRA, Avany de Francisco, MELLO, Mirela Geiger de. 2006. Arquitetura Escolar Paulista: anos 1950 e 1960. São Paulo: Fundação para o Desenvolvimento da Educação.

FERRAZ, Marcelo. 1997. Vilanova Artigas. São Paulo, Instituto Lina Bo/P .M. Bardi/ Fundação Artigas.

FICHER, Sylvia. 2005. Os Arquitetos da Poli: Ensino e Profissão em São Paulo. São Paulo, FAPESP/ EDUSP.

GOSSI, Inez dos Santos. 2005. Arquitetura e Pedagogia: o ambiente escolar. Dissertação de mestrado, Faculdade de Educação da Universidade de São Paulo. 
GROPIUS, Walter. 1977. Bauhaus: Novarquitetura.. São Paulo, Editora Perspectiva. HERTZBERGER, Herman. 1999. Lições de Arquitetura. São Paulo, Martins Fontes.

KAMITA, João Massao. 2003. Vilanova Artigas. São Paulo,: Cosak \& Naify.

KOPP, Anatole. 1990. Quando o moderno não era um estilo e sim uma causa. São Paulo, Nobel/ Edusp.

1986/87. "Modernismo Hoje". AU (Arquitetura e Urbanismo). São Paulo, dezembro/ janeiro.

LIBNEO, Maria Lúcia Leonardi. 1989. A Invenção da Cidade de SãoPaulo. Dissertação de mestrado, Pontifície Universidade Católica de São Paulo.

LIMA, Mayumi Watanabe de Souza. 1989. A cidade e a criança. São Paulo, Studio Nobel. 1995. Arquitetura e educação. São Paulo, Studio Nobel.

. 1979. "A criança e a percepção do espaço". Cadernos de pesquisa. FCC. São Paulo, (31) , 73-80, outubro/novembro.

MANGE, Ernest Robert de Carvalho. 1955. "Arquitetura Escolar". Acrópole. São Paulo (197), 2 I I-213, março. 
MASCARENHAS, Marisa Pulice. 2005. Os Centros Educacionais Unificados da Cidade de São Paulo, Dissertação de mestrado, Faculdade de Arquitetura e Urbanismo da Universidade de São Paulo.

MASCARO, Carlos Corrêa. 1960. O Município de São Paulo e o Ensino Primário (ensaio de Administração Escolar). Livre-Docência, Faculdade de Filosofia Ciências e Letras da Universidade de São Paulo.

MIRANDA, Wander Melo.2002. Anos JK: margens da modernidade. São Paulo/Rio de Janeiro, Imprensa Oficial/ Casa Lúcio Costa.

NIEMEYER, Carlos Augusto da Costa. 2002. Parques infantis de São Paulo: lazer como expressão de cidadania. São Paulo, Anablume/FAPESP.

MEYER, Regina Maria Prosperi. 1991. Metrópole e Urbanismo, São Paulo Anos 50. São Paulo, Tese de doutoramento, Faculdade de Arquitetura e Urbanismo da Universidade de São Paulo.

OLIVEIRA, Beatriz Santos de. 1991. A modernidade oficial: A arquitetura das escolas públicas do distrito federal (1928-1940). Dissertação de mestrado, Faculdade de Arquitetura e Urbanismo da Universidade de São Paulo.

ORNSTEIN, Sheila Walbe; Neto, José Borrelli, 1993. O desempenho dos edificios da rede estadual de ensino- o caso da Grande São Paulo. São Paulo, FAUUSP/CNPQ. 
PESSOA, Denise Falcão. 2006. Utopia e cidades: proposições. São Paulo: FAPESP/ Annablume.

PINHEIRO, Maria Lucia Bressan. 1997. Modernizada ou moderna? A arquitetura em São Paulo, 1938-45. Tese de doutoramento. Faculdade de Arquitetura e Urbanismo da Universidade de São Paulo.

ROLNIK, Raquel. 1997. A Cidade e a Lei: legislação, política urbana e territórios na cidade de São Paulo. São Paulo, Studio Nobel/FAPESP.

São Paulo (cidade). Prefeitura do Município. 1929. Código de Obras Arthur Saboya - lei $n^{\circ}$ 3.427, de 19 de novembro de 1929. São Paulo: mimeo.

São Paulo (cidade). Prefeitura do Município. 1935. Código de Obras Arthur Saboya. São Paulo.

São Paulo (estado). 1936. Directoria de Ensino e Directoria de Obras Públicas. Novos Prédios para Grupo Escolar. Secretaria dos Negócios da educação e Saúde/ Directoria de Ensino.

São Paulo (estado). 1920. Projetos de Grupos, Escolas Reunidas e Rurai.s São Paulo: Serviço Sanitário do Estado de São Paulo. 
SEGAWA, Hugo. 1986. "Arquiteturas escolares”. Projeto, São Paulo (87), 64-65, maio. . 1987. "Disseminando a linguagem arquitetônica carioca em São Paulo". Projeto, São Paulo (105), 143.

1990. "Hélio Duarte (1906 - 1989): moderno e peregrino". Projeto, São Paulo, (|3|), 5|, maio.

1999. Arquiteturas no Brasil: 1900 - 1990. São Paulo, Edusp.

SOMEKH, Nádia. 1997. A cidade vertical e o urbanismo modernizador: São Paulo 19201939. São Paulo, Studio Nobel/ EDUSP/ FAPESP.

SOMEKH, Nádia, CAMPOS,Candido Malta. 2002. A cidade que não pode parar: planos urbanísticos de São Paulo no sáculo XX. São Paulo, Mackpesquisa.

SILVEIRA, José. “O admirável (e quixotesco) Hélio Duarte”. Projeto, São Paulo, ( 13 |), 32, maio.

TEIXEIRA, Anísio. 1957. Educar não é privilégio. Rio de Janeiro, José Olimpio.

VALENTIM, Fabio Rago. 2004. Casas para o Ensino: as escolas de Vilanova Artigas. Dissertação de mestrado, Faculdade de Arquitetura e Urbanismo da Universidade de São Paulo. 
VILANOVA ARTIGAS, João Batista. 1986. Os caminhos da arquitetura. São Paulo, Pini/ Fundação Vilanova Artigas.

WOLF, Silvia Ferreira Santos. 1992. Espaço e educação: os primeiros passos das escolas públicas paulistas. São Paulo, Dissertação de mestrado, Faculdade de Arquitetura e Urbanismo da Universidade de São Paulo.

XAVIER, Alberto. 2003. Depoimento de uma Geração: arquitetura moderna brasileira. São Paulo, Cosac \& Naify.

WICK, Rainer. 1989. Pedagogia da Bauhaus. São Paulo, Editora Martins Fontes. 


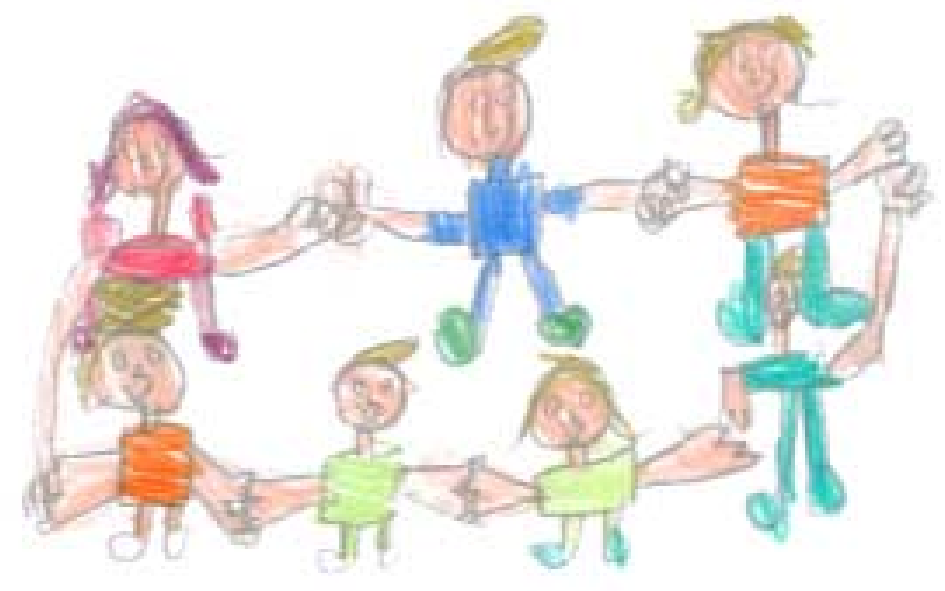

FAUUSP - 2007 